

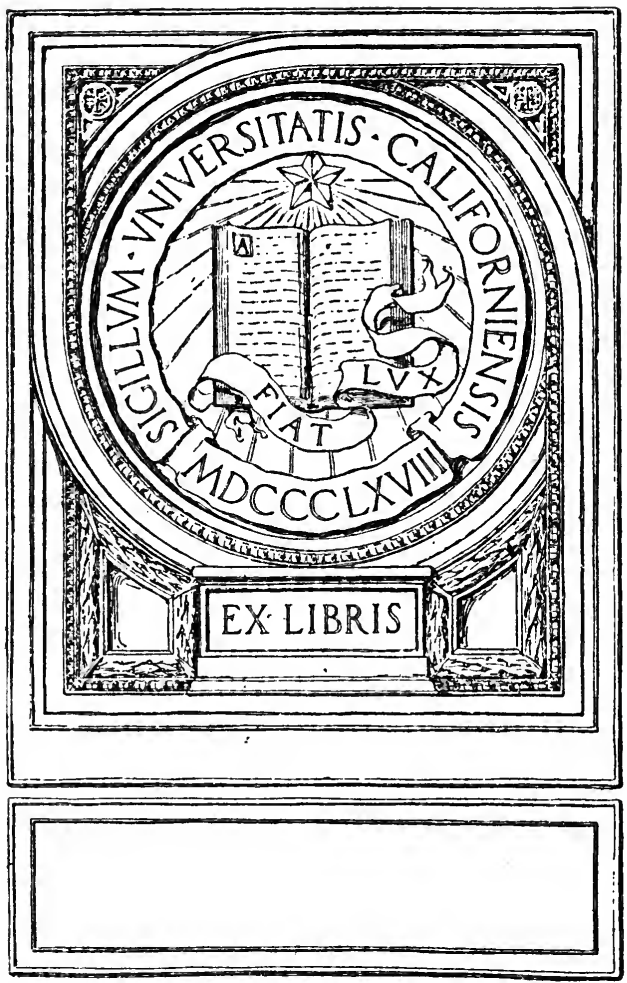



Digitized by the Internet Archive in 2007 with funding from Microsoft Corporation 

College of Missions Lectureship

\section{PROBLEMS IN PAN AMERICANISM}





\section{- PROBLEMS IN}

\section{PAN AMERICANISM}

BY

SAMUEL GUY INMAN

INSTRUCTOR IN INTERNATIONAL RELATIONS IN COLUMBIA

UNIVERSITY, SECRETARY OF COMMITTEE ON

COÖPERATION IN LATIN AMERICA

Author of "Intervention in Mexico," "Through

Santo Domingo and Haiti," etc.

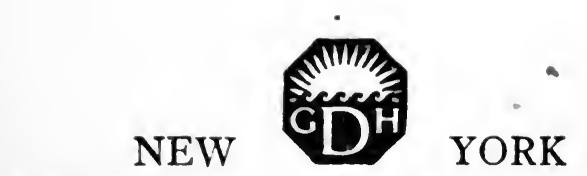

GEORGE H. DORAN COMPANY 


\author{
COPYRIGHT, I92I, \\ BY GEORGE H. DORAN COMPANY
}

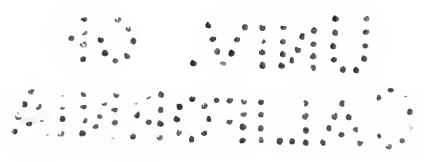

PRINTED IN THE UNITED STATES OF AMERICA 


\section{FOREWORD}

There are two Americas-not North and South, but Anglo-Saxon and Latin. If an accident of history had not given them the same names both peoples might have been spared the serious results of ignoring the significance of wide differences in historical inheritance, religion, language, customs and ideals. But the failure of both parties to take into account these differences has been fatal.

Future historians will wonder that Americans, North and South, lived together on this Continent so long without understanding each other. Present citizens of this America of ours are themselves beginning to ask this question. This book is an effort to help the North American to answer it. Guidance in the selection of material from such a vast field, has not been the desire for a logical but rather for a psychological presentation of the problem.

In the first place, an effort is made to have the reader share in the author's admiration of and belief in the future of the Latin American people. Since it is unfair, however, in drawing up the balance sheet of our friends to have only the credit side presented, the outstanding problems of our Southern neighbors are also given, largely as they themselves have stated them. With these friendly contacts established, history is reviewed to show that in the early days, both in the North and the South, there were warm reciprocal desires for Continental Solidarity, incarnated in Simon Bolivar of the South and Henry Clay of the North. But the Mexican War started a current of suspicion, which the SpanishAmerican War and the extension of North American control over the Caribbean countries developed into hatred. The Monroe Doctrine is shown to have been well received at first in Latin America; reasons for later dislike of it are 
given, as well as the place the Southern Americans would like to see the Doctrine occupy today, in view of the new international situation developed by the World War. The significance of the various Pan American Conferences, from Panama in 1826 to Washington in 1916, is discussed and the radical changes brought about by the World War in the whole problem of Inter-American Friendship are studied. Next are discussed two outstanding questions, without the understanding of which no one can have a deep appreciation of the present status of American Relations. These are the problems connected with the intervention of the United States in the affairs of the small countries of the Caribbean and the resultant growth of the influential school of Pan Latinists, formed by the leading writers of the South who are strongly opposed to the Pan Americanists. Finally, an effort is made to point out a few practical steps that North Americans might take to overcome the handicaps of past mistakes and misunderstandings and build up a true American friendship in which both those of the North and those of the South shall be united in the motto, suggested by an Argentine president, "America for Humanity."

Since the book is written by a North American for North Americans, the recognized right of one to criticize those of his own household has been used freely. The experiences of fifteen years' residence and travel among Latin Americans, intimate friendships with high and low alike, presidents, professors, peons and patriots, real and counterfeit, and a continuous reading of their literature, have inspired the desire to present to my fellow-countrymen the other side of this fascinating problem of harmonious living on our common Continent.

If I have presented here largely the blame attached to North Americans for the inharmony of the past, it is not because it would not be easy to show the blame lying at the door of our neighbors. But others have done that, sometimes ad nauseam. I therefore prefer to help us magnify the good qualities of our neighbors and scrutinize carefully our own bad qualities as the best policy for building international, as it is for building personal friendships. 
The material here presented was first given in a series of lectures at the College of Missions, Indianapolis, Indiana. Since that time it has been tested out in addresses at other educational institutions both in North and South America, and thoroughly revised and enlarged during the author's most recent trip to Latin America in 1921 .

S. G. I. 



\section{CONTENTS}

GAPTER I : ASSETS OF LATIN AMERICA

A land of the future-Room for overcrowded populations-Production of raw materials-Market for manufactured goods-Intellectual and moral resources-Early period: First universities-PressesFine Arts-Literature-Contemporaneous Period: Cosmopolitanism of cultured classes today-A Mexican poet-An Argentine scholar-Youth in the lead -Practical scientists-Contributions to political idealism, governmental reforms, racial relations, estheticism-Kindness-Summary of assets assuring Latin America's place in future world life . .

HAPTER II : PROBLEMS OF LATIN AMERICA

Latin Americans' diagnosis of their own problemsAlberdi - Sarmiento - Zúmeta - Bulnes-Rodó Fombona - Bunge - Garcia - Prada - Álvarez Ugarte - Colmo - Barcos - Calderón - BomfinSummary-The Indian problem-The system of Latifundios - Caste - Suff rage - Immigration-Social problems: Vice, Alcoholism, Hygiene-The economic question-Education-Moral problemsThe religious problem . . . . . . . .

'HAPTER III: EARLY EFFORTS TOWARD PAN AMERICANISM

The Bolivar idea-Introductory-Early expressions in South America of Inter-American friendshipBolivar's idea: The Panama Congress, its constitution and program, Instructions of United States delegates; Results of the congress-Further efforts at unity-The Second congress at Lima-Beginning of suspicion of the United States-Differences between various countries-The Second "American Congress"-Various other efforts at unity . . . 
CHAPTER IV: EARLY EFFORTS OF THE UNITED STATES TOWARD AMERICAN FRIENDSHIP

The period of benevolent neutrality-Early North American champions of friendly relations-Diplomatic agents sent to South America-Clay's fight for recognition of South American republics-Recognition and the period of goodwill-The disastrous war with Mexico-Consequent reversal of feelings in Hispanic America-Fear engendered by talk of "Manifest Destiny"

CHAPTER V: THE MONROE DOCTRINE AND LATIN AMERICA

Origin of the Doctrine-Contents-Cordial reception in Latin America when first announced-Interpretations of the Doctrine by leading authoritiesHow related to collection of debts and internal questions-Opposition to Doctrine arising from imperialistic tendencies-Debate between Bingham and Calderón-Confusion of Doctrine with other policiesThe Monroe Doctrine and the League of Nations; Request of El Salvador for definition-Proposal for an American League of Nations and joint Monroe Doctrine

\section{CHAPTER VI: PAN AMERICAN CONFERENCES}

The United States assumes leadership in developing Inter-American friendship-The First Pan American Conference, Washington, I889: Organization of the Pan American Union-The Second Pan American Conference, Mexico, I90I : Discussions on arbitration-The Third Pan American Conference, Rio de Janeiro, r9o6-The Fourth Pan American Conference, Buenos Aires, rgro: Discussion of Monroe Doctrine-Results of these conferences-The Christ of the Andes-Questions of intervention and collection of debts as related to Pan AmericanismThe Venezuelan collection of claims-MediationThe Mexican experiment-Resultant Pan Americanism 
CHAPTER VII: LATIN AMERICA AND THE WORLD WAR

Economic changes-New credits arranged with the United States-Development of natural resourcesLabor movement-World wide competition for Latin American trade-Political changes-Friendly attitude toward United States-Spiritual effects-Humility-New facing of moral issues-Changes in education-Spiritual unrest-Some consequent dangers-Trade war-Foreign economic dominationAmerican imperialism-Militarism-MaterialismSummary . . . . . . . . . . . .

CHAPTER VIII: PROBLEMS OF THE CARIB BEAN COUNTRIES

Gradual extension of North American control over the Caribbean-Strategic reasons-Economic reasons -Early relations with Cuba-Platt AmendmentSecuring of control over Panama-Absolute control by marines in Santo Domingo-Good and evil results - How the United States' dominance was secured in Haiti-The confusion of governments-Evils of militarism-Neglect of education-Central America's efforts at unity-The Central American Court of Justice-Nicaragua's revolutions which brought the United States' intervention-The Bryan-Chamorro Treaty-Salvador, Champion of nationalism -Recent political changes in Guatemala-Feeling of Central America toward the United States-Suggestions concerning relations between the United States and Caribbean countries . . . . . . .

CHAPTER IX: PAN AMERICANISM VS. PAN LATINISM

Two schools in Latin America-Early admiration of the United States-Later developments of antipathy-Pan Latinism-Outstanding advocates quoted - Godoy - Fombona-Calderón-d'AlbuquerqueVargas Vila-Nuestra America-Ugarte-Eduardo Prado-Periodicals-Anti-American propagandaThe school of Pan Americanists-Outstanding advocates quoted-President Brum-Semprum-Barcas 
-Lobo-Urtecho-Javier Prado-Chocano-Garrigó - Enríquez - Various educators - PinochetNeed of dissipating misunderstanding-Two schools not necessarily antagonistic . . . . . .

CHAPTER $X$ : NEXT STEPS IN INTER-AMERICAN FRIENDSHIP

Review of relations between the Americas-Early friendship as typified by Bolivar and Clay-Change brought by Mexican War-Later steps in imperialism - Confidence renewed by idealism of World WarPresent opportunity for friendliness should be improved by various steps-Elimination of "Big Stick" and "Shirt sleeve diplomacy"-Reaching solution of Mexican question-Caribbean relations-Improved diplomatic service-Better acquaintance with Latin America-New attitude toward the tropics-Awakening to importance of American solidarity in development of proper relations with the rest of the world -Urgency of a better Inter-American understanding -Appreciation of different racial psychology-Value of educational interchanges-Study of Spanish and English-The exchange of good literature-Importance of spiritual ambassadors-The ideal American a combination of the best in North and South . .

BIBLIOGRAPHY

INDEX 


\section{PROBLEMS IN PAN AMERICANISM}




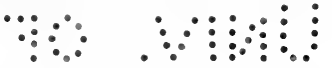

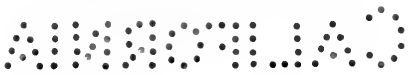




\section{PROBLEMS IN \\ PAN AMERICANISM}

Chapter I

\section{ASSETS OF LATIN AMERICA}

The opening of the Panama Canal changed the map of the world. It inaugurated a world movement toward Latin America. That movement was interrupted by the War but it has started again with new impetus. One only has to go into the counting houses, the offices of steamship companies, of manufacturing concerns, and into the council room of the Foreign Departments of the great governments of the world to realize how intensely the commercial and political organizations are stretching every nerve to extend their influence into these twenty young countries. For they are the land of the future. Unlike the old nations of the Orient their Golden Age lies before them. Just as the most remarkable development of the nineteenth century took place in North America so the most wonderful developments of the twentieth century are destined to take place in Latin America. This is true of Latin America principally because of four great outstanding reasons. First, there is room there for the overcrowded populations of the world. Second, there is power to produce the food and raw products for the world. Third, those lands are a market place for the manufactured goods of the world. Fourth, they possess a remarkable circle of intellectual leaders.

Beginning at the Rio Grande and stretching on down 
through Mexicco: ọver :Centrat Ảmerica, beyond Panama, through Colombia and "Ventiezueia, the Andean countries, Brazil, Chile, down through the abounding plains of the Argentine to the Straits of Magellan, is the largest expanse of undeveloped, fertile land in the whole world. There is more undiscovered territory in Brazil than there is in the whole continent of Africa. One state in that mighty republic equals the area of Great Britain, France, Germany, Austria and Switzerland. If Argentina were as densely populated as is the State of New York, and it is far more capable of caring for a dense population, it would have 225 million people instead of its present population of 9 millions. Venezuela is not considered one of the largest republics but it has three times more territory than Japan, while Japan has a population equal to that of all South America. Arguments might have been made in the old days against. the dense population of these lands because they were tropical but modern science has overcome the difficulties of the tropics for men. The island of Santo Domingo is said to be more capable of sustaining a dense population than any other similar sized territory in the world. The over-crowded populations of the Orient and of Europe will without question seek the great fertile fields and friendly climates of these Latin American countries.

The World War has brought to light the wonderful productive powers of the Latin American lands. In exportation Chile leads the world in nitrates, Argentina in wheat, Mexico in oil, Brazil in coffee, Cuba in sugar, Bolivia in tin, Costa Rica in bananas, - in fact every one of the twenty Latin American countries is especially noted for at least one product upon which the world is absolutely dependent.

The old idea in the United States was that Latin America, being so largely made up of Indians and illiterates, offered little opportunity for our commerce. Business men are gradually awakening to the great error of such an opinion. Little Cuba, with two and a half millions of population, had a foreign commerce in I9I9 larger than that of China, with 400 millions of population. Argentina alone did about 2 billion dollars' worth of foreign trade the year closing June, 1920. In spite of the revolution in Mexico, the United 
States sold more farm implements to that country in 1920 than it did to France, in the midst of reconstruction work.

Because of these basic economic facts there is now going on in Latin America a tremendous struggle between those countries which were formerly allies for commercial and cultural supremacy. Germany and Japan are entering this field with well laid plans. For the first time in the history of the United States she too is making a very serious effort to occupy a large place in Latin American life. Some of North America's greatest business executives are being transferred to South America. Trade commissions from various countries are met in all parts of these southern lands. Prominent representatives of political and intellectual circles from all parts of the world are also visiting these countries. Cultural supremacy is being fought for with little less intensity than is commercial supremacy. This very struggle among outsiders has revealed to the Latin Americans themselves their own strength. The spirit of nationalism is growing rapidly and the people are learning to play off one foreign element against another to the advantage of the national. They have recently begun to develop their own cconomic independence. Thus we have one of the most intensely interesting situations in any part of the world.

These economic possibilities of Latin America have been well advertised. But her people justly complain that little attention has been paid by outsiders to the intellectual and spiritual assets of these countries. It was the frank recognition of these latter assets by Secretary of State Root, whose visit to Latin America in 1906 has been called the greatest event in United States history in the first decade of the twentieth century, that so endeared him to the Southern Republics. He began that remarkable tour by declaring in Rio de Janeiro: "I bring from my country a special greeting to her elder sisters in the civilization of America." Was this a mere compliment to the Latin Americans, an attempt to match their incomparable courtesy? The answer is very clearly revealed by a hasty glance at the civilization of these southern countries.

It will not be necessary to enter into detail upon the civilizations developed by the Indians. The wonderful ruins 
found in Mexico, Central America and Peru are among the most remarkable in the world. Some of the pyramids of Mexico are larger than those in Egypt and the Maya ruins show an architecture comparable to that of the best of ancient Asia. The old fort just outside the city of Cuzco and the many ruined temples in Peru and Bolivia constitute some of the greatest marvels of the archæologist. The city of Machu Picchu, recently unearthed by a North American expedition, has shown the very great antiquity as well as the advanced development of these pre-historic people. The Incas and Aztecs were conquerors of races older than themselves and superior to them in civilization. Unfortunately, most of the evidences of their civilization were destroyed by the fanatical Spaniards. As one of the early ecclesiastics wrote, "We found a great number of their books, but because there was nothing in them that had not some superstition or falsehood of the devil, we burned them all, at which the natives were marvelously sorry and distressed." Surely we share with the natives such sorrow and distress. It is a significant fact, however, that Mexico and Peru became great centers of culture during the Spanish colonial regime.

No doubt, however, Secretary Root was referring to the civilization which the Spaniards brought with them and introduced into these new lands. This in itself, as a brief reference will show, antedated North American culture by many years.

\section{FOUNDING OF UNIVERSITIES}

It is customary to think of the early Spanish settlers as only interested in gold. But the facts show that they had hardly landed on any shore before they began the task of the development of a cultural life. The first university in America, that of St. Thomas, was founded in Santo Domingo in 1538 , a hundred years before John Harvard conceived his plan for a college in Cambridge. It received the patronage of both the Pope and the Spanish king and sent its graduates into Cuba, Porto Rico, Mexico and far-away Peru. Until Santo Domingo lost its prestige it was a notable center of culture and missionary zeal, causing the city to be known as the Athens of the New World. 
A still more famous school is the old University of San Marcos, founded in Lima in 155I. Unlike its predecessor it has maintained a continuous existence up to the present time, and is thus the oldest university in the New World. It has counted among its presidents and professors some of the most distinguished prelates and scholars of America.

In all the following cities universities were organized prior to the first North American college: Mexico, I553; Bogota, 1572; Cordova, I6I3; Sucre, 1623. Practically all of these universities had faculties of law, medicine and theology, while North America's first permanent professorship in theology was established in 1721 , in medicine in 1765 and in law not until after the Revolution. A school of surgery, a college of mining and a botanical garden which were opened in the eighteenth century gave Mexico City a wide reputation for learning in Europe.

\section{PRINTING PRESSES}

The first book printed in the New World was by Fray Juan de Zumárraga, the first Bishop of Mexico, and was called "Brief Compendium of Christian Doctrine in the Mexican and Spanish Language." The Mexican historian, Icazbalceta, has made most interesting historical researches concerning the work of these early printing presses.

The first printing press in America was set up in 1539 in the City of Mexico. The Jesuits of Paraguay built their own presses out in the wilderness where they established their famous missions. They reduced the Guarani language to writing and made their own type in order to publish books of sermons for the Indians. Among the most curious old manuscripts in existence are those still preserved in the archives at Asuncion to reward the trip of a thousand miles up the Paraná River to the Paraguayan capital. In Lima the first issue of the press in 1584 was a catechism in the Quichua and Amará tongues. In spite of the expensiveness of printing in those days, more than sixty books were turned off the presses of Mexico City before the close of the sixteenth century. In 1620 , the date of the landing of the Pilgrims, there were already appearing in Mexico City and 
in Lima occasional leaflets telling of special events-the forerunners of our modern newspaper.

With all these historic developments it should not surprise us as much as it usually does to learn that the greatest modern newspaper plant in the world is found in Spanish America, the magnificent home of La Prensa in Buenos Aires. Its building is one of the great structures of the city. It houses not only the ordinary equipment of a great newspaper, but also a great conference hall, a suite of rooms for the use of distinguished guests of the city, a large restaurant for its employees, a clinic for the poor, a legal aid bureau and many other community services.

\section{ADVANCE IN FINE ARTS}

In Mexico and Peru during the colonial period the Church enjoyed sufficient revenues to enable it to construct magnificent buildings, especially when the work was that of enforced labor of the Indians. Some of these great churches are to this day the marvel of visitors. Something was done in the colonies in painting, and many of the finest canvasses, especially of Murillo, were brought from Europe to adorn the walls of the churches and the homes of the rich.

\section{LITERATURE}

One who has not especially studied the literature of Latin America in the sixteenth and seventeenth centuries is simply overwhelmed when he discovers not only its abundance but its merit.

"La Araucana," by Ercilla, is one of the most remarkable epics ever written. It tells the story of the struggle of the Spaniards in Chile, where after all their sacrifices they were compelled to acknowledge the impossibility of conquering at least one tribe of Indians - the sturdy Araucanians. This long poem was completed in I 590 .

Juan de Castellano's poem entitled "Eulogies on the Illustrious Men of the West Indies," written in the sixteenth century, contained I 50,000 lines.

Juana Inéz de la Cruz, who lived in Mexico from 165 I to 
1695, was called the "Tenth Muse" because of her remarkable poetry. She learned to read at the age of three. She took the veil at seventeen because she was so tormented by those who admired her, both for her beauty and her wonderful intellect. At one time she gathered in her cell 4,000 volumes. She might be called the first American suffragette. She wrote defending the education of women and while a girl herself begged her parents to send her to the University of Mexico dressed as a boy. Her ideas of the Mexican male are given in the following poem on men:

Stupid men, forever prone

To fix a blame on woman's reason,

When 'tis merely your own treason

That creates her fault alone!

With an unrestrained desire

For her downfall you are scheming;

You are of her virtues dreaming

While to ill alone you fire.

Her resistance you oppose,

Then, all serious, attaint her

Fickle, light, and faithless paint her,

Though 'twas you the rôle that chose.

Stupidly you would procure

Baser for a nobler treasure;

Making Thais of your pleasure

A Lucretia chaste and pure.

Nothing could be funnier

Than the tale of him befouling

His own mirror and then scowling

Because the image was a blur.

Whom is the greater evil in-

Though both in wayward paths are straying-

The poor sinner for the paying,

Or he that pays her for the sin?

Come, from your flirting cease, and turn,

If may be, to a cool reflection,

Then blame the still alive affection

Of her you started first to burn!

-Translation of Thos. Walsh. 
A literary contest was held in Mexico in 1585 in which three hundred poets took part. I am not sure that we ever had such a contest in North America and we certainly should not have had three hundred poets here before the landing of the Pilgrim Fathers. Señor Arenos de Mello reports that in 1780 his great-grandfather, living in interior Brazil I 400 kilometers from the sea, a man who had never seen the ocean, listened in his home to the presentation by a company of amateurs of some of the tragedies of Voltaire.

In the life of John Miller, an Englishman who took part in the struggles of Argentina and Bolivia for independence, are found some interesting references to the great intellectual power of the South Americans. The old patriot Guarachi, a native of $\mathrm{La} \mathrm{Paz}$, of pure Indian blood,--was more familiar with English history than most Englishmen. He knew as much concerning the civil wars between the houses of York and Lancaster as if they had taken place in his own country and in his own generation.

The Peruvian Indians had natural talent for painting and sculpture. They had little knowledge of the principles of art, but were able to copy paintings very successfully. One picture painted by a native of Quito, which was taken to Europe, was considered one of the best paintings of a fine private collection in Brussels. An Indian of Arequipa made some wood carvings representing. Inca figures, which were sent to the Emperor Alexander of Russia. He was so delighted with them that he conferred upon the Indian the Order of the Santa Anna.

\section{PRESENT DAY INTELLECTUAL CIRCLES}

Nor did these early intellectual currents spend themselves and disappear in the deserts and forests of these lonely lands. It is a fact, startling to many, that there is today in the capitals of Latin America, an intellectual class comparable to that found in the capitals of Europe. My experience leads me to make the strong statement that, on the average, the intellectuals of Latin America have a broader and finer culture than those of North America. The North American is more specialized in his knowledge. He must "major" in 
some special branch in college. One of our great educators has said that the Doctorate of Philosophy, which is a highly specialized course, is the educational fetish of the United States. A large percentage of our university men lack that general culture that makes them agreeable in any company, and capable of talking intelligently on any topic.

The educated Latin American, on the other hand, is apt to know how to talk and act under all circumstances, as he generally speaks several languages and has traveled in many countries. A hundred examples of the bruskness of the educated North American as compared with the refined manner of the Latin come to the mind of anyone who has often seen the two together. This was forcibly brought home to me a few years ago when I met a company of North American educators in Rio de Janeiro. They had been specially selected from our college circles to visit South America as representatives of North American culture in the promotion of closer relations with South American universities. It came over one immediately on seeing them with the reception committee at Rio de Janeiro at what great disadvantage they appeared in comparison with their Brazilian hosts.

Another illustration was afforded by a young Harvard graduate who, because of a brilliant record, had been given a scholarship and an exchange professorship in the University of Chile. While waiting to be presented to a certain class to which a professor was talking about the young man's work, he walked around the room with his hands in his pockets looking at the pictures on the wall. The Chilean professor was so incensed that he publicly requested him to show proper respect and be seated. Later the young man caused further criticism of Harvard by wearing as head dress a little cap, familiar to our college campuses, but considered by Chileans as not only childish but lacking in respect.

When the Mexican-American Commission was sitting in 1916 at Atlantic City, a gentleman said to me, "Our men must find it very trying to sit day after day in conference with those Mexicans, so inferior in culture." How highly humorous the remark was could not be lost on anyone familiar with the personnel of the Joint Commission. Some 
inkling may be gained by those who were not so acquainted from the manner in which the Commission decided a certain question. In view of the superior culture of the United States' representatives, they would naturally be prepared to carry on discussions in the language of their foreign associates. Did they? As a matter of fact the amount of Spanish possessed by the three American commissioners was negligible, whereas all three of the Mexican members spoke English, two of them fluently. The discussions were in English. And whatever others may think of the Mexican Commissioners, their American associates had no illusions either as to their culture or as to their intellectual acumen.

North America's ignorance of those Latin Americans who have made great contributions to the literary and scientific world is irritating and appalling. Some ten years ago there came to this country for a series of lectures a man whom Juan Velara, a noted Spanish literary critic, called the greatest lyric poet in the annals of Spanish literature. But his presence in this country was hardly known to any outside the smallest Hispanic circle. A little later he passed into the life beyond with hardly a reference to him in North American publications. This was Ruben Dario, one of the world's outstanding figures in literature.

\section{A MEXICAN POET}

What is the single event that has probably attracted more attention in Latin America than any other since the signing of the Armistice? A North American audience could not guess in a thousand guesses. It was not the passage of some law, the victory of some political party, the beginning of some great new enterprise or the defeat of treaty ratification by the United States Senate. It was the death of Amado Nervo! Amado Nervo? And who was he? Nobody, so far as the United States is concerned. Three years ago he passed through New York on his way from Mexico to Buenos Aires where he was to serve his country as Minister. It is true that a few of us met together in a small lecture room in Columbia University to listen to him recite those most marvelous spiritual visions that have made men nobler 
wherever the Spanish language is spoken. But New York did not know that he was in her midst. Later, when he died in Montevideo, Argentina and Uruguay sent battle cruisers to accompany his remains to Mexico. Cuba caused her warship also to join the escort into Vera Cruz. There was thus formed a more remarkable demonstration of Latin American friendship than has been seen for many a day. For weeks it was the principal topic of discussion in the newspapers of Mexico, Cuba, Argentina and Uruguay.

Nervo was the philosopher of the quiet faith, a man who loved nature and men and sleep. In one of his little known poems he says, "Friend, your poems are very good and I certainly enjoy listening to them, but what I really wish to do now is to go to sleep, for he who sleeps dreams and is therefore a god."

Amado Nervo is at his best when he interprets the Bible and mysticism in general. This little stanza on à Kempis is often quoted and misquoted:

O, Kempis, Kempis, pale and ascetic,

I have been sad for years,

There is illness in my soul;

And it is all on account of the book you wrote.

The "Mystics" shows Nervo in one of his best developed moods. It leaves in the mind of the reader a lingering sense of procession, of pale browed pageantry. Thomas Walsh has made a translation close to the spirit of the original :

Bards of brow funereal

With your profiles angular

As in ancient medals grand;

Ye with air signorial,

Ye whose glances lie afar,

$\mathrm{Ye}$ with voices of command;

Theologians grave and tried,

Vessels of love meted grace,

Vessels full of sorrow found;

Ye who gaze with vision wide,

Ye whose Christ is in your face,

$\mathrm{Ye}$ in tangled locks enwound- 
My muse a maid marmoreal

Who seeks oblivion as her stay,

Can find alone her rapture fanned

Amid your air signorial,

Amid your looks that lie afar,

Amid your voices of command,

My soul that doth your spirit trace

Behind the incense's rising tide

Within the nave's calm shadow ground,

Hath loved the Christ upon your face, Hath loved your sweep of vision wide, Hath loved your tangled locks enwound.

Away up in Asunción, Paraguay, a thousand miles from the coast but only a few miles from some of the wildest tribes of Indians in existence, one finds a circle of literary men. One of the few Americans who visited that city not long ago called on a member of this circle. The Paraguayan was suspicious of him at first and began an examination: "Tell me about my Emerson," he said to the North American, who fortunately knew something of the New England philosopher. "Tell me of my Whitman," he said again, and then, leaning back in his chair, after a few minutes he said, "Now tell me of my Po-a (Poe). Ah! That's the finest thing I have heard in a long time. You are the first American I have seen down here who knew anything about my Po-a and these other dear friends of mine."

Because of Latin America's early literary development she has an immortal song of the great victory of Bolivar at Junin. What would we not give had there been a bard in our Revolutionary days to sing such a hymn in honor of our own Washington! The poem is entitled "La Victoria de Junin," and was written by José Juaquin de Olmeda (I780-I847). Here is a part of this remarkable pæan, scarcely excelled in all literature. (Much, of course, is lost in translation.)

If to Americans, $\mathrm{Oh}$ Liberty!

The solemn mission is by Heaven given

To curb and tame the horrid beast of war,

And over all the regions of the earth, And over all the waters of the seas 
To spread thy sovereign rule's imperial sway, Fear not with such a hero as Bolivar

That error blind shall e'er obscure thy light,

That superstition shall profane thy altars,

That tyranny shall dare affront thy laws.

For thee shall be the glory, Oh Bolivar!

For thee the right to break the yoke of kings,

In their despite to enthrone the law on high.

Forever shall this glory last, ye nations,

And irresistible your free estate

Shall be before the might and hateful league

Of all the tyrants that have sworn to crush you.

If in a federal bond from pole to pole,

In war and peace ye live fore'er united.

In union is your strength, union, $\mathrm{Oh}$ nations!

That ye be always free and never conquered.

A mightier work, Bolivar, is this union

Than to destroy Spain's iron rod of power,

And thou alone art worthy to achieve it.

A bosom friend of Olmeda's was Andrés Bello, a much more typical Latin American intellectual, because he was not only a poet, but a great grammarian, a statesman and pedagog. His keen understanding of his people is found in his pointing them to agriculture as one of the surest antidotes to civil discord and international strife.
"O youthful nations, ye who lift your heads
Encircled with new laurel wreaths of victory,
Before the gaze of an astonished West!
Do honor to the fields, with honor lead
The farmer's simple life, homely and frugal,
Thus freedom shall abide with you forever,
And ye shall always curb
Ambition, and respect law's sacred might."

Another one of those marvelous brains that accomplished an unbelievable amount of work and whose influence radiated to every corner of the Spanish-speaking world, is Eugenio Maria de Hostos. Here is one of those Latin geniuses that seem to be capable of doing any amount of intellectual work in any number of different spheres. He 
wrote one of the best treatises on constitutional law that has been published. An edition in English is scheduled for the near future. His educational principles, which were given through his years of teaching in the normal school in Santo Domingo, show some of the most modern pedagogical theories. It is planned also to publish these as soon as his old students are able to work them out from their notes. A volume called "Meditando" shows the remarkable intellectual grasp of the man. First there is a long essay on Hamlet, a splendid critical study of Shakespeare's play; then follow short essays on several of the great men of South America; a criticism of various authors in Santo Domingo; a treatise on the laws of teaching, on political themes and on literary criticism. This remarkable man was educated in Spain, traveled all through Latin America, came to be a recognized authority in literature and politics in Argentina, Chile, Santo Domingo, Cuba and Porto Rico, in all of which countries he lived for a more or less brief period of time. Before Europe had opened scientific careers to women, Hostos had persuaded the Chilean government to open its courses in medicine and law to women. He was also the first man to urge in Argentina the importance of the construction of the Trans-Andean railway. In Santo Domingo he edited the first laws concerning education and directed for nine years the public education of that country. While in Peru he began a campaign in favor of the protection of the Chinese there and aided the national government in its controversy concerning the Oroya railroad. He worked most arduously for the independence of Cuba and offered to earn by means of his pen a million pesetas for the Liberal cause.

\section{AN ARGENTINE SCHOLAR}

I treasure as one of the finest experiences of my life a visit a year or two ago to the home of Dr. Ernesto Quesada, the great Argentine scholar. I was met at the door by the butler and ushered into a beautiful room filled with rare art treasures and the armor of forgotten knights. From there I was directed to proceed into the adjoining room, where I should find the head of the house. This was a large room 
probably fifty feet long, lined on every side with well-filled bookcases running to the very top of the high ceiling.

I advanced rather cautiously, but hearing voices at the other end, found Dr. Quesada with a half dozen friends, seated around the fireside. On being presented to the guests I found myself in the midst of a literary circle which reminded me of that which used to gather at Cambridge in the days of Emerson and Holmes. There was Dr. Carlos Peña, combining the faculties necessary for a famous theatrical critic and the editor of a forty-volume work on Argentine law, and several other gentlemen distinguished in the intellectual life of Argentina, including the Director of the Historic Museum of La Plata. The conversation took wide range, from university life in the United States to secondary education and teachers' problems in Argentina, the celebration of the Fourth of July, the formation of the Argentine soul from many different sources, etc.

We afterward broke up into small groups and began examining the wonderful library. Dr. Peña accompanied me, showing me many of the later books of the library and giving me very valuable information concerning Argentina literature. It is interesting to note how this author works. He asked me my opinion of the plan for his "History of the Constitution." His thought was to begin in a large circumference and gradually close in until he arrived at the Argentine constitution itself.

In the first place, there will be a study of the European constitutions, showing that these were entirely monarchical and could have no influence on the Argentine constitution. He will then take all of the American constitutions, giving the largest study to that of the United States, showing that Argentina copied practically the entire constitution of the United States. He would then begin his intimate study of the constitution of his own country and its interpretation. This will be a two-volume work of about I,400 pages. Did I think that would be sufficiently inclusive? I replied that of course it would be a rather brief treatment of the case, but it would possibly suffice.

It is doubtful if our scholars and leaders are doing the research work in literature that is being done in Argentina. 
There seems to be no limit to the ability of authors there to turn out large tomes. The books by Dr. Quesada are placed by themselves in his library. They fill more than five feet of space. One volume alone, the "Study of the Teaching of History in the European University," has I,200 pages.

Before we left that evening we heard many things about new books, written by the various authors present, books that were yet to appear, and arrangements were made for future meetings when chapters of these forthcoming works would be read and criticized by this circle of friends.

By special invitation I returned to Dr. Quesada's on Saturday evening to attend one of his classes in sociology. It was a very delightful experience to see the close relationship which exists between this professor and the young men and women who were invited into his library. The subject was "Aztec Civilization," and a paper of nearly one hour's length was read by one of the young men, showing great familiarity with Aztec sources but not very much power of interpretation. The paper was followed by criticisms by the class, which were as keen as anything heard in the graduate classes of North American universities.

I was convinced of the accuracy of what one of the university professors had said to me the evening before, that no students in the world are better prepared intellectually for entrance into the university than those of Argentina. "One of our students can be asked," the professor said, "about the geography of India, for example, and he will enter into the most minute details concerning it. But the great difficulty is that these young men are tired mentally. They have no intellectual initiative. They are not capable of specialization or of penetrating to the very roots of a subject and drawing practical conclusions from it. If we want specialists in any branch," he added, "we must go to North America for them."

\section{YOUTH IN THE LEAD}

A short time ago I was in the office of the director of primary education in Mexico City, an officer who controls all primary education in the city and is the head of an organization with a budget of $\$ 6,000$ a day and em- 
ploying 2,000 teachers. As one follows this young man through the various offices in the municipal palace, sees the respect everywhere accorded him, hears the waiting teachers appeal to him and is shown the modern, well-regulated office whose records keep him constantly informed of every detail about each individual school and teacher, instinctively one turns to see if after all there isn't some trace of a wrinkle or gray hair about what seemed at first a boyish face. But there is none discoverable. He is just twentyfour years of age. Two years ago a member of the graduating class of the Escuela de Altos Estudios of the University of Mexico, he was president of the National Student Federation. He tells with enthusiasm of his work with the students, which he still continues; of how he has been seeking to lead the students from a "Latin American Solidarity" to a "Pan American Solidarity"; of his earnest desire to go to the United States for graduate work; of what he believes the students of these two neighboring peoples could do, with the proper backing, toward developing closer friendship between the two countries, and finally of what he is doing in his present position to help educate his people. At this point he produces statistics to show that in spite of all the difficulties with which they are faced, which sometimes even include lack of funds to pay teachers' salaries, there are today more pupils enrolled and more schools open in the City of Mexico than there were in I910, the last year of the Diaz administration.

This is one illustration of that which constantly impresses the traveler in Latin America-the brilliancy of the student classes.

The students of Latin America are probably more responsible for creating what there is of "public opinion" in their several countries than any other force, excepting only the newspapers. They exercise extensive control over educational matters by means of strikes. This phenomenon is very common in Latin America. Akin to the strike, which is generally in protest against something relating to the internal management of the individual school, is the "demonstration," which is organized for the purpose of protesting against some public procedure that is believed to be 
wrong. Student demonstrations during the war have been quite common, and often exercised immediate influence.

If you should call at the suburban home of Oliveira Lima, in tropical Pernambuco, your first impression would be that ex-President Taft, unbeknown to you, was visiting Brazil. Dr. Lima is wellnigh our ex-President's exact double in physical appearance. As you talk with the great Brazilian you are impressed also with the fact that intellectually he is the same quiet, dignified type of gentleman, with the same broad, sympathetic nature and scholarly thoroughness which we admire in Mr. Taft. His dissertation on international peace, as we sat together on his veranda, surrounded by palms and cocoanut trees, was one of the most beautiful that I ever heard. He formerly represented Brazil at the Court of St. James. In his London home he collected a library of 33,000 volumes, which he has recently donated to the Catholic University at Washington, where he now lives. $\mathrm{He}$ is one of the most genial of men and refutes the charge that Latin Americans cannot appreciate a joke. He laughed most heartily when, referring to his likeness to President Taft, I asked him if he had heard why Mr. Taft was considered the most polite man in Washington-because he got up and gave two ladies a seat in a street car.

Pernambuco was also the home of Señor Nebuco, one of the most cultured gentlemen who ever graced the diplomatic circles of our national capital. $\mathrm{He}$ completely won the hearts of the people of the United States while he was among us as Brazil's ambassador. $\mathrm{He}$ was the first diplomat to urge publicly, in his farewell address to President McKinley, that all the American nations should assume equally the duties and responsibilities of the maintenance of the Monroe Doctrine. Among the many great deeds credited to his skill is the freeing of the slaves in Brazil, which was done not by a terrible war, as with us, but by a gradual and equitable arrangement between the government and the slave owners.

\section{PRACTICAL SCIENTISTS IN LATIN AMERICA}

It is not alone in the world of letters that Latin Americans find an important place, but as scientists as well. The 
traveler who today approaches Rio de Janeiro will have little interest in the old controversy as to whether Naples, with its broad sweeping bay and amphitheater of hills rising over the colored crescent city, or Constantinople, is the most beautiful city of the world. For Rio de Janeiro-with its blending of hill, mountain and valley crowned with tropical verdure, over all of which preside the stately royal palms, on the shore of an island-studded bay that the early narigators imagined was a river's mouth-Rio de Janeiro is immediately recognized as incomparably the most beautiful of the world's cities.

But for many decades the city was shunned by all who were not absolutely compelled to go there. Plague slew its thousands and yellow fever its tens of thousands. From I89 I to I894 there were 14,445 deaths from yellow fever alone. But a young Brazilian physician, Dr. Oswaldo Cruz, in one of the most remarkable achievements of modern science, has made Rio de Janeiro as healthy a tropical city as one may easily find.

Dr. Cruz, after graduating from the School of Medicine in Rio and taking further work in the Pasteur Institute in Paris, became convinced of the possibility of making his own city as healthful as any in the world. "Give me the proper authority and a sufficient force and means to work with and I will rid Rio of yellow fever in three years," said this young man just past thirty years of age, with no special reputation and no special knowledge of the disease or its method of propagation. The President took him at his word and appointed him Director General of Public Health.

On April 20, 1903, less than thirty days after his appointment, the first case of yellow fever was rigorously isolated, and a campaign begun based on lines adopted by the American Commission in Cuba. With a force of seventy-five physicians, a number of students and a large force of laborers, he began his stupendous task. When, in 1906, he resigned the position of Director General of Public Health to assume the headship of the Institute of Tropical Diseases, now known as Oswaldo Cruz Institute, Rio was free from the scourge of yellow fever and Dr. Cruz became a world figure, better known in Europe, it is true, than in the United States. 
It was Aniceto Menocal, a Cuban, who many years ago traced out for the future construction of a canal across Central America the route which was later recommended by the American engineers at the conclusion of their elaborate and exhaustive surveys. Two young Peruvians have become noted as aviators-Jorge Chavez and Juan Bielovucio. The former was fatally injured at Demodossola, Italy, on September IO, I9IO, after having flown across the Alps. The latter flew across safely at the same point in Igr3. One of the first and most famous kings of the air, Santos Dumont, is a Brazilian.

\section{LATIN AMERICA'S POLITICAL IDEALISM}

Some are inclined to ridicule the democracy of Latin America, and, in fact, it exists practically in only a few of the countries. In spite of this, however, which is due to many historical influences easily pointed out, Latin America's devotion to democracy is wonderful. For example, Mexico in spite of a century of disappointments and sad experiences, although she has suffered much, keeps to her republican ideal. The execution of Iturbide and Maximilian, who dared to suggest an empire, shows this.

The growing vision of equalitarian, fraternal, righteous commonwealths, in which the good of all shall be the quest of each, has become a passion with a considerable group of patriots. If in part it is a recrudescence of the original Spanish genius for individualism and autonomy ere yet the Spanish state was overborne by monarchical absolutism and imposed tradition, this passion is more fully explained by the resilience and creative energy of the Latin American mind itself when once it is free to follow its native élan.

This democratic idealism has only incipiently realized itself in the overthrow of imperialism and the setting up of republics. It has soaring dreams of the future. It utters its prophecies in the political ideology of statesmen, the enthusiasms of sociologists, the fervid eloquence of orators, and above all in the indigenous literature of the young democracies, both poetry and prose. From the early poetsAndrade of the Argentine, Olmedo of Ecuador, Gregorio 
de Mattos of Brazil, Marti of Cuba, de Tagle of Mexicodown to the days of Santos Chocano of Peru and of Rubén Dario of Nicaragua, dean of the present modernist school, the American masters of Spanish and Portuguese verse have never ceased to sing of new hopes and alluring prospects rising out of the ruins of the shattered past.

There is much strength in that devotion to ideal political conditions, so often criticized by those whose god is the practical. Faith in grand sonorous principles, in arbitration, democracy, etc., and generous vagueness of humanitarian declarations, their people in love with the poetical in politics, inheritors of a heroic quixotism, they often invoke pure justice in a world usually governed by selfish interests. At times this leads to the most heroic self-sacrifice and the accomplishment of things which the practical Saxon would have considered impossible. Thus Juaquin Nabuco points out that Princess Dona Isabela, regent of Brazil in 1888, declared voluntarily the freedom of the slaves. She thus separated herself from the conservatives, from the landlords and from slave owners and contributed directly to the elimination of the monarchy and the founding of the republic in Brazil. Devotion to a principle cost her the government of an empire. It was only an idealist like Francisco Madero that seemed capable of rousing the Mexican people to revolt against a political and economic despotism reaching back into centuries.

The French Revolutions of 1789 and 1848 both had profound influence on the Latin American, the latter movement finding echo in new parties demanding suffrage, equality before the law and other reforms. The idealism of Lamartine was everywhere shared in South America. He had written in 1848 that "Democracy is in principle the direct reign of God." So groups appeared led by such men as Vilbao and the Lastarria brothers in Chile, Antonio Guzmán in Venezuela, and in Colombia by democratic clubs, one of which, because of its appeal to Christ as the great democrat, was called Gólgotha.

The theory of democracy is more carefully thought out by Hispanic America than by us. We take it for granted, but she studies it. Latin America has made the fullest con- 
tribution to the elaboration of the theory of democracy made by any people. By virtue of French ideas and North American example they threw off the Spanish monarchy and set up a democracy. With no experience in self-government they were in need of a gospel of democracy to which they could hold, even though they wandered far from its ideal in practice. Some of these early writers seemed almost inspired, in the Biblical sense, so keen was their analysis of the situation.

Montalvo of Ecuador taught that "a sane and pure democracy has need of Jesus Christ." He exalted Christianity as the author of democracy and believed that democracy would be the law of the nations if some day the spirit of the Gospel were to prevail. Lastarria of Chile was one of the greatest students of political economy and defenders of democracy. In his wonderful book, "Lessons in Positivist Politics," he applied principles of Positivism to the evolution of South America and particularly Chilean history.

Juan Bautista Alberdi, almost unknown to us, was one of the greatest students of democracy that has ever written upon the subject. He believed that "philosophy is meant for politics, morality, industry and history, and if it does not serve them, it is a puerile and a trifling science"; while he desired a philosophy "in which are distilled the social and moral needs of our country, a clear democratic progression and popular philosophy"; he defended Protestantism as a religion peculiarly appropriate for republics on a Catholic continent.

His fellow Argentine, Sarmiento, better known, has also written some of the best treatises on government ever produced in America. He became a friend of Horace Mann, while a resident, of this country, and found in the United States the larger part of his model, which he worked out later as President of Argentina. Of his more than a score of books, "El Fecundo," one of the best, has been translated into English by Mrs. Horace Mann.

If in the practical development of democracy Latin America has generally been behind North America, this is not true in one important matter, the freeing of the slaves. Simon Bolivar, himself, led in this movement by ordering the lib- 
eration of the several hundred slaves on his own estate. In the Central American Congress, on December 31, I823, Father Cañas, rising from a sick-bed, made an impassioned appeal, which reminds one of Lincoln's addresses during his candidacy for the Illinois Senate, thirty-five years later. The worthy father said: "I come limping, and if I were dying I would come as my last act, to perform a noble deed for humanity. With all the energy with which a deputy should promote the interests of his country, I beg that, before anything else is done, and on this very day, our brothers who are slaves be declared free, leaving free the right of those who have legitimately secured these slaves to make their claims and the immediate creation of a fund for the indemnification of these owners. *** The whole nation has been declared free. Thus should also be the individuals who compose it."

The very first article of the decree which the Liberator of Mexico, Don Miguel Hidalgo, issued in 1810 , was "First, that all owners of slaves shall give them their liberty within ten days, the penalty of death resulting in the disobeying of this decree." Hidalgo's defeat caused the postponement of emancipation but this was fully consummated under the presidency of Guerrero in I829.

The cultured and humane deputy, Manuel Salas, presented and with his enthusiasm carried through the Congress of Chile, on October II, I 8 II, a bill which provided that all persons born in Chile should be free, and all slaves who set foot on the nation's soil should thereby become free.

Buenos Aires followed with a similar law on February 2, I813, and other Spanish American countries followed suit. In 1838 decrees of freedom were issued in Colombia, Venezuela and Ecuador. So it will be seen that, with the exception of Brazil, which was an empire, all the Latin American nations anticipated the Emancipation Proclamation in North America by half a century and by a lesser time the movement in England, which was consummated in 1825.

SOME GOVERNMENTAL REFORMS

Those who are interested in the great social and economic problems that are stirring the world today should watch Uru- 
guay. It seems heretical for anyone to entertain any doubt that the United States of America, with its president, cabinet, congress and supreme court, as now formed, represents the very last word in democratic government. But Uruguay, after trying that form for a century, has just made a radical change which is expressed in a new constitution just adopted. For some time this progressive little country has been attracting world attention on account of certain social legislation which seemed distinctly radical. Today, with her new constitution, she may be considered the social laboratory of America.

Here, in brief, is what she has done: The power of the president is greatly limited, the executive power being divided between that office and an administrative commission of nine members which is elected every six years by popular vote. This commission prepares an annual budget for the congress, to which it is accountable. Minority representation on the commission is assured by recourse to plurality of votes, as in England. Legislative powers remain in the congress, but the congress also elects the members of the supreme court of the republic, approves or rejects treaties made by the executive and has the explaining and interpreting power in questions involving the meaning of the new constitution-thus taking for the legislative body the power that has always been the peculiar strength of the Supreme Court of the United States. Congress may call on members of the cabinet for explanations of their acts, as in England and France, and the ministers have seats in the congress with power to introduce legislation. When congress is not in session it is represented by a permanent committee, after the Mexican plan, composed of members of both houses, who deal with the executive in all matters of adjustment between the two departments.

Such a comprehensive governmental reform cannot help but yield highly instructive results, and the wise application of the practices and principles revealed ought to make for progress along such lines in all the western nations.

The following from one of its distinguished writers is not an overdrawn statement of Latin American intellectual life: 
"There are certain general principles, like democracy and arbitration, which are scarcely disputed in America. The idea of arbitration as a judicial means of deciding international differences owes its origin to Bolivar, the Liberator of the New World. We South Americans also have our Walt Whitman. Social sciences throughout the whole continent have made greater progress than metaphysics and theology. Rivals of Giddings and Lester Ward teach in South American universities, and over against the work of Wheaton we can set the work of Calvo. Pragmatism, the philosophy of North America, is also the philosophy of Spanish South America, and, in the books of Alberdi, a sociologist of Argentina, we find thoughts to which William James and his disciples subscribed half a century later. We are forced, then, to believe in the definite relationship between the physical order and the moral order. The New World has a geography and a policy which give it genuine originality as compared with Europe."

\section{LATIN AMERICA'S CONTRIBUTION TO THE PROBLEM OF RACIAL RELATIONS}

The greatest of world problems are those related to the living together of different races. In respect to acceptance of the doctrine that God made of one blood all the nations of the earth, we may find that the Latin Americans are superior to the North Americans. They did not destroy the Aborigines when they came to this new land as did the North Americans. They intermarried with the Indians and today there is no prejudice against them. Indeed, the average man is much prouder of his Indian blood than of his Spanish ancestry. In spite of the introduction of African slaves and a resultant large negro population in countries like Brazil, there is practically no color line or race problem in any of these countries. There is no such aversion to the Chinese, the Japanese and the East Indians as is shown by the North Americans, Australians and Dutch.

The distinction between the races is in Spanish America a distinction of rank or class rather than of color. Against intermarriage there is, therefore, no more feeling than that 
which exists against any union palpably below a man's or woman's own rank in life. If it is rare for a pure white to espouse a pure Indian, that is because they are of different ranks, just as it is rare for a well-born Englishman to marry a peasant girl.

\section{LATIN AMERICAN LOVE OF THE ARTISTIC}

While our southern neighbors have not produced any very great artists, yet they have men who stand high in the world of music, painting and sculpture. But here again, if we take the average man, we find that he is a much better judge of the artistic in music and in other arts than is the average North American. The "popular" airs that the band in the plaza plays are not the fleeting ragtime, but are well-known selections from the operas. The military bands which, in Mexico, for example, are found giving popular concerts in two or three different plazas every night, are made up of the lowest classes. Music is natural to them and some of these men who have never worn a pair of shoes would be capable of accompanying Tetrazzini or Galli-Curci in the "mad scene" from Lucia.

The love of the beautiful is remarkably illustrated in the Latin American cities, which are among the most beautiful in the world. The most important official is not ordinarily the mayor, but the man who is responsible for the beautifying of the city. A few years ago this official in Buenos Aires came to believe that it was necessary for the national capitol and the President's residence to be united by a broad avenue. It made no difference that the cutting of this avenue would mean the destruction of buildings in the most crowded business section of the city and the expenditure of millions. The municipality gladly voted the necessary funds, condemned property and built the beautiful Avenida de Mayo, which is now recognized as one of the most beautiful in the world. The heights of the buildings are carefully regulated. The modern demands for the skyscraper have been recently worked out by having the higher part of the building set back in the center part of the street. It is interesting to note that New York has followed the example 
of Buenos Aires in some of her newest tall buildings. It is hoped that we will follow her example in other things. It is impossible to imagine Buenos Aires or Rio de Janeiro allowing unsightly gas tanks or New York Central railroad tracks to be built right along a beautiful waterfront such as the Riverside Drive. There is probably no waterfront more full of natural beauty than the one in Rio de Janeiro. One feels that it is fortunate that nature has done this for a Latin city rather than one of our own, for we might not have co-operated with her as has Rio de Janeiro, resulting in the most beautiful ocean drive in the world.

This love of the artistic is found just as strongly among the most humble classes. The Mexican peon may have no more clothes and furniture than he can put in a couple of blankets, but the difficulty of his moving from one house to another is augmented by the fact that he absolutely refuses to leave the plants and flowers that are always a part of his existence. I know of nothing more pathetic or beautiful than to see a peon trudging along the road with all of his belongings on his back, with his wife and children accompanying him, loaded quite as heavily with their precious little pot plants.

\section{KINDNESS}

Perhaps the greatest of all characteristics of the Latin American is his kindness, and open-heartedness. It is the thing above all others that makes the foreigner so love to live in those southern lands. Charity is not simply a duty, it is a matter of course. If a poor relative dies and leaves helpless children, they will be taken into the family, it makes no difference how little room there may be or how empty the larder may be. If one is without a job, or in hard luck, his more fortunate relatives will always lend a helping hand. There are never too many in any household to keep another out, if he is needy.

One of the outstanding experiences of a lifetime was that of driving in a single buggy for four hundred miles through desert country in Mexico, accompanied by my wife and a year-old baby. We knew nothing of the way. We were 
dependent on the country people for lodging, for food for ourselves and forage for our horse, for milk for the baby. If we had been a royal family, instead of humble absolute strangers and foreigners besides, we could have received no greater kindnesses. Sometimes we had to drive for hours before coming to a country hut. If we stopped to inquire the way, the reply would be that we must come in first for a cup of chocolate. Then they would tell us, and if the road was difficult, often someone would go with us long distances to make sure that we took the right turn.

\section{SUMMARY}

With all these fine qualities in the people and with all the riches of the soil, one risks little in prophesying that Latin America is to occupy a most important place in future world life.

Here then are all the conditions maturing for great movements and consequences. Crowded populations made aware of productive, unoccupied lands tend to migrate. The progressive stabilization of government calls forth capital formerly reluctant. Railroads throw open regions hitherto inaccessible and idle. The advance of scientific sanitation renders the old cities and new territories safely habitable. But more important than all of these material riches is the wealth found within the people themselves.

As Clemenceau, after his visit to Latin America, said: "A country, whatever may be its form of government, is strong only through its men, that is through the sum total of its disinterested energies. Now a people capable of producing men of intelligence and character of those I frequently met during my trip can confidently face the problems of the future."

Notwithstanding the inherited passion for politics, more of the youth of Latin America than formerly are preparing themselves in engineering, scientific agriculture and commerce, and other productive vocations. In nearly every one of these nations a group of leaders and a constituency are either in power, or are emerging, looking forward, committed to universal education, political stability, social justice 
and international good will. These brought to bear in fullness upon the limitless natural resources of the countries and their patrimony will realize the belief of most observers that Latin America's Golden Age is ahead and imminent.

An illustration of what we may expect Latin America to contribute to the world, once the average level is lifted, is shown in the following production of the Cuban, José M. de Heredia. Exiled by the Spaniards in 1823 , he came to Boston at the age of 23 , and eked out a few years of miserable existence in this country by teaching Spanish. He almost starved at times. But he managed to see Niagara Falls. As a result, we have his immortal description of that great natural wonder.

Tremendous torrent! for an instant hush

The terrors of thy voice, and cast aside

Those wide-involving shadows, that my eyes

May see the fearful beauty of thy face!

I am not all unworthy of thy sight,

For from my very boyhood have I loved,

Shunning the meaner track of common minds,

To look on Nature in her loftier moods.

At the fierce rushing of the hurricane,

At the near bursting of the thunderbolt,

I have been touched with joy; and when the sea

Lashed by the wind hath rocked my bark, and showed

Its yawning caves beneath me, I have loved

Its dangers and the wrath of elements.

But never yet the madness of the sea

Hath moved me as thy grandeur moves me now.

Thou flowest on in quiet, till thy waves

Grow broken 'midst the rocks; thy current then

Shoots onward like the irresistible course

Of Destiny. Ah, terribly they rage,-

The hoarse and rapid whirlpools there. My brain

Grows wild, my senses wander, as I gaze

Upon the hurrying waters, and my sight

Vainly would follow, as toward the verge

Sweeps the wide torrent. Waves innumerable

Urge on and overtake the waves before,

And disappear in thunder and in foam.

They reach, they leap the barrier-the abyss

Swallows insatiable the sinking waves.

A thousand rainbows arch them, and the woods

Are deafened with the roar. The violent shock 
Shatters to vapor the descending sheets.

A cloudy whirlwind fills the gulf, and heaves

The mighty pyramid of circling mist

To heaven. The solitary hunter near

Pauses with terror in the forest shades.

God of all truth! in other lands I've seen

Lying philosophers, blaspheming men,

Questioners of thy mysteries, that draw

Their fellows deep into impiety;

And therefore doth my spirit seek thy face

In earth's majestic solitudes. Even here

My heart doth open all itself to Thee.

In this immensity of loneliness

I feel Thy hand upon me. To my ear

The eternal thunder of the cataract brings

Thy voice, and I am humbled as I hear.

Sources of Further Information on Assets of Latin America

Calderon, F. Garcia : Latin America, Its Rise and Progress.

Clemenceau: South America of Today.

Coester, A.: Literary History of Spanish America.

COOPER, C. S.: Understanding South America.

ForD, J. D. M.: Main Currents of Spanish Literature.

Godoy, F. Garcia: Literatura Americana de Nuestros Dias.

Goldberg, IsaAC: Studies in Spanish American Literature.

Lima, Oliveira: Evolution of Brazil Compared with Spanish and Anglo-Saxon America, Na Argentina.

Shepherd, W. R.: Latin America.

Root, Elinu: Latin America and the United States.

Files of "Inter-America" and "Bulletin of the Pan American Union." 


\section{Chapter II}

\section{PROBLEMS OF LATIN AMERICA}

Granting that Secretary Root's gracious and now famous phrase concerning the salute due from the younger civilization of North America to the older civilization of Latin America was entirely justified by the facts, as brought out in the first chapter, this does not mean that Latin America is not confronted with grave and difficult problems, on the solving of which her future place in world life depends. In making up Latin America's balance sheet we must examine not only the credit side of the ledger, but must frankly face the debit side as well.

\section{LATIN AMERICANS' DIAGNOSIS OF THEIR PROBLEMS}

None have been readier to recognize or franker to describe the things that are holding back these nations than have the Latin Americans themselves. In the beginning of their independence they were too taken up with political questions to consider in any large degree social and moral problems. The remarkable school of writers, to which reference has already been made, who treated political idealism and the problems of democratic government as reflected from the French Revolution of 1848 , touched indirectly the social problem. Juan Bautista Alberdi, of Argentina, an outstanding authority, wrote a book called Bases for the Organization of the Argentine Republic, in which he analyzed the evolution of Argentina much as Hamilton in his Federaiist studied North American life.

Domingo F. Sarmiento, the greatest of Argentines, was the only aggressive worker for social reform known in South America in the early days. His two remedies for social evils are expressed in his own words as follows: 
"I have projected two 'bases' for the regeneration of my country: the education of the present inhabitants, in order to raise them above the moral and racial degradation into which they have fallen, and the introduction of new races into the society of today: 'popular education and immigration.' I have followed these two ideas, I have traveled that I might clarify them, perfect them and make them practicable. In the prosecution of them I crawled-I must say it, as money was scarce with me-to the United States, and regarding what I saw and examined there, all my later writings bear testimony."

But from 1860 to 1890 books on political and moral questions were rare indeed, due partly to the great international wars of that period. From about 1890 , however, we find a school of Latin American sociologists developing, and books written since that time show a keen analysis of the problems of those countries.

In his book, The Sick Continent, César Zumeta of Venezuela, the forerunner of these sociologists, studied the outward and inward danger of Latin America, the ills of the race and its questionable future. He and other sociologists following him seemed to be stirred to an analysis of the weaknesses of their people, particularly because they believed they saw a new imperialism in the United States which was destined to overcome Latin America if she were not able to repair her weaknesses and protect herself. In I899 Francisco Bulnes, a well-known Mexican author, in The Future of Hispanic American Nations, wrote of the future of Latin America in comparison with the progress of the United States. A more pessimistic outlook can hardly be imagined. He makes sport of the legends concerning the riches of Mexico, Peru and Brazil. The curse of Latin America, he holds, is that it is tropical. In those hot zones industrial and progressive nations can never flourish. Alcohol and laziness perpetuate slavery. The entire stretch of territory from Cuba to Bolivia will have by 1980 , predicts this pessimist, lost its independence.

Bulnes examines the Latin American vices, such as bureaucratic selfishness, jacobinism and megalomania. He ex- 
plains the South American revolutions by the economic conditions of those countries. As industries do not exist, the state must feed the middle class, and if it does not satisfy their desires by enlargement of the bureaucratic public offices, then revolutions begin. He doesn't find in Latin American republics any of the virtues of democracy; not veracity because they exaggerate their riches and grandeur; not justice because inequality and intolerance dominate; not cooperation for the public good because of jealousies which have been inherited from Spain.

After Bulnes comes that friend of young men, the Uruguayan author, José E. Rodó. In his book, Ariel, he gives magnificent advice to his young friends. He teaches them, as against the solicitations of politics, anarchy and violence, the worship of the inner life, faith in the multitude, in democracy, in the foundation of a future élite which will develop freely in democracies. His ideal for all America is the conservation of Latin traditions and dreams in this prosaic modern age, the fusion of the essential inspirations of Christianity and Hellenism. Equality is provisional, inequality constant and necessary. Vulgarity and utilitarianism are essential attributes of the young North American democracy. But the excess of practical activity, the power of ambitious plutocrats, the mediocrity of commercialism, in North America work against his ideals for South America -which are unselfishness, nobility, cultivation of art and of intellect. He believes that in republics threatened by bureaucracy there should be a circle given up to culture.

Blanco Fombona of Venezuela, in his Political and Social Evolution of Spanish America, studies the conflict of the classes during the Spanish domination, and argues that civil wars are explained by the mixed Indian populations, the sparsity of inhabitants, the scarcity of railroads, ignorance and lack of liberty. In spite of these things he believes in the great destinies of the continent. "Cities of 45 thousand inhabitants, as Buenos Aires had a hundred years ago, now have a million and a half. The I 5 million of South America's population in 1810 are now 70 million. In countries where Europe had no investments formerly there are tremendous commercial enterprises now. Foreigners who a 
century ago were prevented in Spain from establishing themselves in America, today occupy a large part of the new world."

Fombona's novel, The Man of Iron, is a satire on social conditions in Venezuela, written while in prison as a result of his governorship of the territory of Amazonas, "as wild as in the days of the conquistadores and whose population has the reputation of assassinating governors." The book is rich in keen and sarcastic conversations of special types of people, in descriptions of priests, of pious women and of earthquakes. Revolutions, he finds, are often to be ascribed to personal vanity, like the one led by Joaquín Luz, who, in a gaudy uniform, addressed his bedraggled followers as follows: "Redeemers! Let us depart for war. Our cause demands it; our country needs it. Let us sacrifice our lives to overthrow tyranny and restore law and justice. Weapons the enemy has. Take them away from him. Hurrah for the revolution!"

The book of Bunge, Our America, reminds one somewhat of Carlyle's pamphlets. He writes concerning American vices, concerning the psychology of the creole and of the mulatto, and explains the power of the great despots such as Rosas, Moreno and Diaz. He traces the lack of morality to capitalism and the class distinctions common among Indians, negroes, mulattos and mestizos.

Juan A. Garcia, another Argentine sociologist, discusses the weakness inherent in the imaginative exaggeration, the "more or less" way of putting things, the pessimism, the arrogance, the Spanish blood which is revealed in the lack of respect for law, the cultivation of anger and daring. In his most famous work, La Ciudad Indiana, he says: "The proletariat leads a miserable life, in the most wretched huts built upon waste lands, a simple squatter upon the vacant lots of the city where he sets up his shanty. $\mathrm{He}$ eats the butcher's leavings or subsists on the alms of the great house. He has not the least idea of any possible social betterment. According to his view his situation is final, like that of his companions in misery, the Indians and the negroes. Work is useless, and he resigns himself, aided by his hereditary temperament-a term that has been applied to the effect pro- 
duced by the traditional education, which taught both the oppressors and the oppressed that the world is as it is because God wills and has made it thus, and that $\mathrm{He}$ is angry with those who rebel against $H$ is will and sends upon them terrible punishments over and above those imposed by the king."

Gonzales Prada, until his recent death the director of Peru's National Library, one of her most brilliant sons, the leader of a large school of South American literary men, attacks fiercely the immorality of Peru. As he examines her life, he sees everywhere abounding corruption and weakness. "Littleness pervades everything, littleness in character, littleness in hearts." He launches his heaviest invectives against. what he calls "la mentira social"- the social lie. He says, "Peru is a sick organism; wherever the finger is applied to her she exudes pus." Such conditions drive him to a black pessimism and make him exclaim, "Existence and sorrow are synonymous. The most worthy work of a God would be to reduce the universe to nothing."

Franz Tomaya, a young Bolivian sociologist, says :

"We believe that peoples were made for the service of rulers and not for the service of peoples; we believe that learning ought to be acquired to satisfy our personal concupiscences, and not to increase the welfare of all; we believe that art, and very especially the art of writing, ought to be treasured like a heritage or a cow, instead of being the divine, elevating and sublimating instrument of the inner man whom we carry within us; we believe in the fecundity of laziness, in the efficacy of the lie, in the lawfulness of every scheme that leads to success, although it be a stranger to honesty."

Agustin Alvarez, in his book, South America, and in countless articles published in periodicals, proves himself to be one of the keenest analysts of the reasons for the woes of his countrymen. He is known as the "Emerson of Argentina." In studying the causes of social unrest in South America he traces it to the fact that "the proletarian was surprised by the revolution headed by the proprietors who 
had been excluded from the honors and advantages of power, and which he could not explain to himself as a change of political condition but as a change in social condition, because he never felt the need to govern, but had always been pushed along by the need to live. *** So the disappointment of the proletarian, who had acquired in the revolution the consciousness of his worth and power, caused us an additional thirty' years of civil war."

Alvarez is particularly severe on the abuses of the Church and of the proprietors of the great landed estates. He says:

"The two great calamities of the colonial period were contempt for work, considered as a punishment imposed by sin, and fear of knowledge, regarded as a risk for the salvation of the soul. Upon these two premises some consume in an inverse proportion to what they produce, while others produce in an inverse proportion to what they consume, and society is composed of laborers brutalized by want and ingenious idlers luxuriating in a hothouse of comfort.

"By always viewing the qualities of others in the light of our own interests, we attain at once to the ingenuousness of the boy hunter who complained that 'the quail are becoming more and more shy and will no longer allow themselves to be killed.' He was not different, certainly, from a very religious professor who raised a cry to heaven because he had to pay to the peons of his vineyard a peso for eight hours of work at present, when formerly he paid them half a peso for sixteen hours, while considering the increase in the price of grapes very just because it meant money for him-and the increase in the cost of the peon very unjust because it was taken out of his pocket.

"This is how Christianity, which began by being the religion of the humble, changed into the religion of the powerful, when the pastor turned into a potentate and could no longer perceive the needs of the ruled except as they touched the interests of the rulers.

"According to the theory of colonial morality, man was born to suffer in this world and to reap his reward in the next. Therefore the frightful cruelty of the tutelary régime, springing from natural instincts, had obtained religious sanc- 
tion and it could not now be diminished, but rather was aggravated, by the pastor of souls, who, under the lash, extracted from the hunger of the Indians the ecclesiastical tributes, and under the lash drove them to mass and rosary: the degradation of man for the glorification of God."

Manuel Ugarte, who is today the outstanding enemy of the United States in Latin America, has written an important analysis of Spanish American life in a book called The Future of Latin America. He points out with cruel frankness the weak points of his people which must be strengthened if they are to resist the "octopus of the North."

Alfredo Colmo, professor of law in the University of Buenos Aires, is a self-made man and brings to the study of his people his own struggles as a background. His book, The Countries of Latin America, is the latest and probably the most extensive of the sociological treatises and is full of criticisms of his own people and praise of the Anglo-Saxon. He says:

"What has the United States in common with the countries of Latin America? Very little: the incidental fact of its geographical location in the same hemisphere and the external circumstance that it became independent at almost the same time. $* * *$ What, then, does it offer by way of unlikeness? Nearly everything, and in terms so disparate that they are but little less than diametrically the opposite of one another. Details and secondary matters apart, the contrasts, in which these countries never hold the place of vantage, are the following: populousness and habitability; wealth and misery; deeds and words; activity and atrophy; education and inculture; industry and politicalism; commerce and militarism; order and impulsiveness; legality and defiance of law; free will and arbitrariness; morality and egotism; truth and falsehood; principles and men; railways and mules; civilization and stagnation and even barbarism; liberty and slavery, etc."

The following from an address I heard him give on July 9th, I9I7, in commemoration of Argentine independence, 
gives an idea of this scholar's way of thinking. Generally on such occasions wonderful eloquence is used in applauding heroes of the past, but Dr. Colmo entirely changed this order of things. He said at the very beginning, "I am going to make a simple talk. I like to talk to the heart and not to the stars. I want to flee from academic discussion. Latin America emphasizes entirely too much the intellectual. We seldom find any of us who have the power of initiative. Anglo-Saxons are the highest expression of character the world has ever known. A bouquet is made up of flowers, but an independent nation cannot be developed except by men. We have an infinitude of riches in our soil and yet as citizens we are never satisfied until we have gotten a position with the government and have been able to issue a book. Even if we decide to exploit some of our riches, we do it not with our own capital, but demand a concession from the government. We have emancipated ourselves nationally but not individually. This is the one great problem before Argentina-to emancipate ourselves as individuals, to initiate new things, to stand against the common sins and temptations of the majority.

"The Young Men's Christian Association comes among us and is a real Temple, which shows how the Anglo-Saxons stand out individually for what is right and noble. I know of no organization, whether it be of laboring men, of a university, of business men, or what not, in Anglo-Saxon countries, that has not as its real basis a moral purpose, because it puts emphasis on individual morality and initiative. Too often men on patriotic occasions cry 'Patria! Patria!' but when you look into their lives you find that they really care nothing for the Patria. They are dishonest; they do not pay their debts; they do not tell the truth; they are not honestly working for the good of their country. The small shopkeeper, who never so much as gives a grito for the country in public, but who works constantly to build up his little business, to educate his family, to treat his neighbor honestly, is a greater citizen than the man who makes speeches continually, crying out publicly for the Patria."

Sr. Julio R. Barcos, a leader of the younger generation 
who has lived a good deal in the United States, published in his magazine, Cuasimodo, a remarkable series of articles, in which he takes decided issue with such writers as Rodó, Ugarte and Fombona:

"Alberdi is not writing a mere literary paradox when he says that 'next to the liberators, the poets are the most dangerous enemies of liberty in South America.' For a century these false idealists, wrapped in the romantic style, have had the floor in the government, in society and in the realm of literature in Hispanic America. They found a world ready made, and their mission has been to reverence it servilely, thus perpetuating the prejudices and castes of the colonial period. We have to confess that, thanks to such educative elements, we are still spiritually molded after the image and likeness of our mother Spain. We have changed only the surface of our customs and beliefs, but in reality, in the depths of our psychology, there is in every one of us Hispanic Americans an embryo soldier, monk or rascal, a remote inheritance of the Pizarros, Loyolas and Gil Blases who, in emigrating to these shores, grafted either their blood or their souls upon the aboriginal stock of our America. In truth, if we do but slightly lift the skin of our double moral personality we discover that while we call ourselves republicans we venerate monarchy. We have excluded the king, but we preserve the royal pomp, and the enormous bureaucratic scaffolding of the epoch of the viceroys. We are liberals at the club and ultramontanes at home; we are gentlemen in form, idealists in words, and opportunist Philistines at bottom during the twenty-four hours of the day.

"We have had enough of the camouflage of knighthood, for there is now not a rascal in these lands who does not wear the harness of a knight. Even Don Quixote in this America, according to Alberdi, without ceasing to be always the same old fool, has become also a knave and a peculator. We have a superfluity of haughty and punctilious gentlemen who speak to us in verse and poetic prose, and are lacking in true men, genuine men, who move upon the vast and multiple stage of real life and awaken the soul of these torpid 
peoples to the naked and terrible truth of their immense vital problems. How many are the great, noble, strong things that remain to be done in America! I shall be told that we are highly cultivated men, artistic writers, eminent poets and brilliant politicians, even philosophers, sages and sociologists. We have such, yes, as a luminous nucleus, surrounded by an immense opaque body formed by our masses -hungry, barefoot, filthy and illiterate pariahs. This is the general rule in Latin America. What influence have these, the intellectual élite, exerted upon the fate of the community? $* * *$

"Everything remains to be done among us; all that has already been accomplished by those peoples who really live the civilization of the twentieth century, while we go along on all fours, still in the infancy of the nineteenth century. It is high time for us to come forth from the contemplative ecstasy of our soft and ideal life, more appropriate to oriental potentates than to virile men, in order to pass over to the dynamic life sound in body and spirit in all their potential forms: love, work, strife, creation and the constant irradiation of our personality. Enough of literary magpies without soul and without a purpose in life, who, along with malaria and uncinariasis, form a part of our American epidemics. We have already poetized long enough; it is time that we abandon the cerebral infantilism of ridiculous literary tournaments, which have made of every South American a Crœsus in verse and a beggar in ideas, in order to enter the formidable ideological tournament which affects the very heart of the social problems of our epoch; that we abandon the brilliant rhetoricians for thinkers filled with optimism and the vainglorious thaumaturges of art for the sincere priests of life; that we redeem ourselves, in short, from the disease that killed Spain-wordiness-in order to enter the real, energetic, laborious and fruitful life, by mingling without cowardice in the torrent of the great human struggle that draws us toward the heroically intellectual life like a new Marseillaise.

"Welcome to our America be all foreigners, even if we do not always share their doctrines, because they bring to 
us at least a breath of intellectual realism that will cause us to throw aside the crutches of invalids sunk in a quagmire of trickeries and imbecilities peculiarly ours, and advancing rapidly toward the future, putting ourselves first on a level with Europe and surpassing her later, not in so-called 'culture,' which is what old men and old peoples treasure, but in the fervor of humanity translated into human redemptions; that is, the victorious achievements of life: public hygiene, bread for the people, individual liberty, education, redeemed labor, joy for all, the abatement of plagues in the form either of microbes or of men, the suppression of the pariah by the suppression of the master."

Garcia Calderon is the only author treating his countries' social problems whose work has appeared in English. His book, Latin America, Its Rise and Progress, while more philosophical than sociological, is of great importance as an analysis of the struggle of the new world Latins.

Manoel Bomfin, a Brazilian, has written an important treatise in his Latin America, in which he traces most of the ills of these countries to their inheritances from their mother countries. The fact that their problems in all the various countries are practically the same he contends is ample proof of the theory of parasitism.

This is not a complete list, by any means, of the men who have written books on the social and moral problems confronting Hispanic America, but it gives an idea of this school of thought which has developed since about 1890 and, as was said before, seems to have been animated particularly by what a writer in La Revista de Chile in I 895 called "The brusk change in the traditional policy of the United States seen in its present imperialistic tendency, which will no doubt consolidate in the great northern republic the arrogant pretensions of the politicians of the Blaine school, who consider it manifest destiny that their country shall exercise commercial hegemony and political tutelage over the rest of the continent.'

Three things are particularly noticeable about these writers. The first is the tendency to philosophize and generalize 
rather than to collect detailed facts in specific fields of investigation upon which definite lines of advance could be marked out.

The second observation is that sociologists are entirely too few in these countries. As Professor Megalhaes of Brazil says, "We have in Brazil many poets, many artists, many journalists. But it is rare to find among our public men one who dedicates himself to social studies. Rare indeed are the practical works which study national economy. Learned men often prefer to exchange a real and irrevocable immortality, which might be obtained by serious investigation, for the ephemeral laurels of romance and of the theatre."

The third important thing to note about these writers is that all of them express faith in these countries. Their pessimism is confined to the present, based on a defective social system and the lack of immigration. Even Bulnes believes in Mexico, Argentina and Chile. Blanco Fombona says that the balance sheet shows at the ending of a century of independence a distinct amount in favor of these countries.

Manuel Ugarte thinks that the wonderful prosperity, the miraculous progress and the superior social conditions of Argentina, Brazil, Mexico and Uruguay are a prophecy of what may be expected of the whole continent when ruled by "a unified doctrine."

Bunge thinks that in spite of the inferiority of the mestizo, the continent may save itself by the American people assimilating European culture or by producing a civilization of their own as the Japanese have done. He affirms that with the correction of Hispanic American defects his people will be superior to the Yankees and the Europeans, but he falls under his own criticism of "more or less" ways of stating things when he fails to suggest definite ways of achieving this.

A consideration of the future place of Latin America in world life requires brief reference to some of the important unsolved problems, which, until solved, must hold these countries back from first place among the nations. 


\section{THE INDIAN PROBLEM}

Although, as earlier indicated, the process of assimilation by the Iberian conquerors in the early days went on rapidly, resulting in the large mestizo population which constitutes the bulk of the inhabitants today, it must be said that this process seems now to have practically ceased, leaving intact an aggregate community of some eighteen millions of pure Indians, scattered from Mexico to Patagonia.

The early culture of their own civilization, so remarkable among the Aztecs of Mexico, the Mayas of Central America, the Chibchas of Colombia and the Incas of Peru and Bolivia, has been swept away and they have all been segregated from the influence of modern life. Consequently they stand out in peculiar and pathetic isolation.

Perhaps the most terrible indictment of the government's treatment of the Indians in South America is made by Sr. Alcides Argüedas in his well-known book, A Sick People, for the writing of which the author is compelled to live outside of Bolivia, his native land. Concerning conditions among the Indians in Bolivia, Señor Argüedas says:

"Blinded by different and contradictory creeds, under the material and moral influence of the priests, the patrons and the public officials, his soul is a deposit of rumors from time past. When the flower of his race was shut up against its will in the heart of the mines, he wasted away rapidly, gaining the help and sympathy of none. $* * *$ This hate has accumulated so that the race has lost its best characteristics. Today the Indians are the object of general exploitation and general antipathy. When this exploitation in an aggressive and brutal form arrives at a maximum and the sufferers have corne to the point where they have gotten beyond the power of human endurance, then the Indian rises, forgets his manifest inferiority, loses the instinct of conservatism and, listening to his soul, filled with hatred, looses his passions and robs and assassinates with terrible vigor. Authority, patron, power, priest-all are forgotten by him. The idea of reprisals and punishment, if it occurs to him, acts only as on the fiendish tiger escaped from his den. Afterward, when 
he has given free rein to all of his passions, let the soldiers, the priests and the judges come and kill and rob-it makes no difference; and certainly they come. Certainly they kill, they rob, they violate, they sow terror on all sides. Those who escape death are taken before lawyers and judges, wellread, whose occupation consists in showing the terrible apparatus of the law. The Indians are put in obscure gaols and taken out once in a while under the armed vigilance of soldiers and made to work ten hours a day without food sufficient to sustain their poor, weak bodies after so much privation."

The visitor to South America will see nothing more pitiful than the Indians of Peru and Bolivia, descendants of great civilizations now forgotten.

In Cuzco one is at the center of the Indian population of Peru. Riding on horseback through the Ilcamaya, one of the most wonderful valleys in the world, one has the opportunity of seeing the Quechuas in their old haunts, where they have lived for many centuries. Here are found the ruins of great temples and fortresses. Wonderful terraces running up the mountain sides a thousand feet or more are still under cultivation, although built by pre-Inca peoples of whom we have no knowledge.

In the shadow of the magnificent ruins which typify the former greatness one sees, for instance, a company of halfclad men and women bearing the body of a dead friend to the grave. The corpse is wrapped in a blanket and carried on one man's shoulder or between three or four people. It is their one time to enjoy a holiday. They are invariably armed with the cheap native gin and are reeling and cursing and fighting. The fray becomes so interesting that they lay the body down and argue wildly with their hands. One of the women strikes a man and knocks him across the corpse. A free-for-all fight ensues until they are all lying on the ground, so drunk they cannot rise. There they lie until the stupor is worn off and then proceed to the grave. Maybe they have a Padre to say the last rites or maybe it has been impossible for them to collect sufficient funds to command his costly services. 
How have the mighty fallen! In the old Inca days the common salutation as they passed one another on the road was a reference to their two fundamental laws. The first traveler would say "Thou shalt not steal, thou shalt not lie." The other would reply, "Nor shalt thou do either of these." The modern salutation is "Ave Maria purissima," and the reply is "Sin pecado concebida" (Conceived without sin). Above the door of the Catholic Church on the main plaza of Cuzco, next to the University, are these words in bold letters: "Come unto Mary all ye that labor and are heavy laden, and she will give you rest."

Anyone who wishes to understand how the Indians are exploited by government officials and priests should read Birds without Nests, a novel by Clorinda Matto de Turner, a native of this district. The plot is developed around a brilliant young lawyer, supposed son of the governor, and a young Indian girl, who is being reared by a philanthropic Spanish family. When they fall in love with one another and are about to be married, it is revealed to them that they are both children of the same priest. "We were born Indians, slaves of the priests, slaves of the governor, slaves of the chief, slaves of all who have a club to drive us. Indians! Yes. Death is our only and beautiful hope of liberty." Madam de Turner, like Señor Argüedas, paid the price of her writings in banishment from her native country until her death.

In southern Chile I called on a former chief of the Araucanians. He received me with as much style as his broken estate would allow and had the accustomed feast prepared. But he could talk of nothing except his lost land. I tried to get his mind away from his troubles by telling him about the wonderful city of New York. He would appear interested for a moment or two, then would turn and say, "But my land, Señor, my land!" Then I would try him on the war, telling him of the tremendous guns, the tanks, and all the wonderful things that modern civilization has developed with which to kill men. This interested him greatly, but only for a few minutes and then again, "But my lands, Señor. You are going back to Santiago. Will you not see the President and explain to him how our lands have been taken 
away from us and that we cannot make a living on the little that we have now? We want our land."

The following clipping from a $\mathrm{La} \mathrm{Paz}$ daily duly presents another side of the Indian question:

"To the President of the Hon. Council of the Province of Arque:

"It is my painful duty to report the following shameful charges against Isidoro Claros, priest of Quirquiavi :

"In a sermon he told the Indians that those who obeyed the municipality were savages, adulterers and ex-communicated; that neither the municipality nor the President had anything to do with the Church. He recently ordered the Indians to close up a street which the municipality had opened.

"He demands from the Indians taxes he has not the least right to demand.

"In less than a month he has collected from Manuel Bel$\operatorname{tran} \$ 56$ for burial rites and $\$ 32$ for masses, and now threatens to send his church officials to take possession of the property of the widow.

"From Gaviano Checa, another poor Indian, he demanded \$I 2 for having pronounced a blessing over his deceased sister, but Checa not being able to pay, the priest seized four of his sheep and intends to take possession also of three llamas, the property of the deceased sister.

"From another widow this heartless wretch has extorted $\$ 32$ for masses and responses.

"He thinks that being a parish priest he is the owner of all the property of the Indians, whom he fleeces extravagantly in the face of public outcry. He goes to their preserves in search of sheep, which he secures by saying a few prayers over their belongings in order to keep away the evil spirits. He intrudes into the huts and performs these ceremonies against their wishes. He brings them from their ranches and makes them marry against their will, just for the money it brings him.

"In August last he whipped a poor widow named Maria Tola from the Church to her house, because she had informed the municipality that he had extorted $\$ 32$ from her. 
He left her, saying, "That will teach you not to go to the municipality.'

"The man does just as he pleases and says he fears nobody and no authority."

Franz Tamayo believes that the pure Indian, the native Aymará and Quechua, are the great sources of national energy in Bolivia. The author tries to show the characteristics of the Indian, his virtues and his faults.

According to Tamayo athletic contests have proven that the Indian is stronger than the white. "The most moral, that is to say the strongest element in Bolivia, is the Indian; then comes the half-breed, on account of his Indian blood, and lastly the white, who is the parasite of the nation, which owes its life to the Indian."

The author looks upon the petty task of teaching the Indian how to read somewhat scornfully. The primary school, as it exists in Bolivia, has weakened the Indian and made a parasite of him, he says. Before giving him instruction, they should instil in him good habits. The Indian's energy is there, but it must be guided in the right direction and intensified, not weakened by a veneer of culture.

The main idea of the whole book is this: Bolivian racial characteristics must be studied, the destiny of the race must be foreseen, and a national system of education built up, not copied servilely from Europe, but one of their own creation, adapted to existing facts. And for this work the aid of foreign psychologists, educators and sociologists must be solicited.

The Hon. Ignacio Calderón, recently Minister of Bolivia to the United States, invited to say a word about the Indians, wrote as follows :

"I am glad to have this chance to make an earnest plea in favor of the Bolivian Indians. They are the descendants of the great Inca empire, a people that had reached a very high degree of peaceful civilization when the Spaniards conquered and took possession of their lands. The Inca Empire, according to tradition, was founded by Manco-Capac, helped by his wife, Mama-Ocllo, and they based their rule 
and domain not in the use of force, but in the teaching of the arts of peace and mutual help.

"At the time of Pizarro's arrival the Inca Empire extended in the north up to what is now Colombia, and towards the south to northern Chile and Argentina. Wonderful highways connected the various portions of the vast empire, and the people lived contented and happy under the fatherly rule of the Incas. But the Spaniards, taking advantage of the awe which they inspired with their firearms and the sight of ironclad soldiers mounted on strange looking animals-the Indians never having seen horses before - subdued them easily and reduced them to mere slaves to their will and power.

"Once masters of the country, the Spaniards treated the conquered Indians more like cattle than as human beings. No right, no consideration whatever, was allowed them. The history of the Indian race during the centuries that have passed since the conquest is an uninterrupted tale of woe, of misery and degradation. The once noble and happy sub. jects of the Inca became pariahs in their own land; mere tools of the whims and desires of their masters. All ambition was thus taken away from the Indians and distrust and indolence became prevalent instead. In spite of all that they are the only agriculturists of my country, working in the fields as well as in the mines.

"The Bolivian Government has lately very commendably given some attention to improving the miserable condition of the Indians and has established some schools for them. Unfortunately, neither are the resources of the country sufficient nor are there enough teachers available, inspired by that noble self-denial that moves the heart and sustains the will of the Christian missionaries in the great work of educating and improving the souls of the downtrodden.

"There are many millions of these unfortunate Indians in the different countries of South and Central America and Mexico, who are in dire need of help. They are nominally citizens of the several republics, but have little idea of what that means. As long as they are kept in their present state they will remain a great stumbling block to the orderly and democratic development of the various American republics. 
"The Indian needs to be educated, especially in manual training and in the use of agricultural implements to replace the obsolete and primitive methods they now use. They could be taught carpentry, blacksmithing and other useful and necessary industries that they could do well and which could profitably meet their needs."

\section{THE SYSTEM OF LATIFUNDIOS}

At the bottom of all the social problems of these countries is the land question. In the early colonial days great sections of land were given to Spanish settlers and whole tribes were assigned to these landlords in order that they might be educated and at the same time furnish the labor necessary. The landlord generally forgot about his duty to educate the Indian, but never his duty to make him work. Often the church authorities, as was particularly the case in Mexico, worked the Indians unmercifully in building great cathedrals. On passing through a city like Querétaro one is astounded at the number of great churches and can only understand how it was possible for these to be built when he is told that they cost the Church practically nothing, by reason of this enforced labor.

During the period of independence also many of these lands have been given to individuals for political favors, so that all over Latin America there exists more or less a feudal condition. The proprietors of these great landed estates in Mexico paid, before the present Revolution, about twentyfive cents a day for their labor. A man with a family of a dozen might be excused for going in debt with such a wage. In fact, the land owner encouraged his getting in debt. These debts held the man to the farm. They are passed on from him to his children and to his grandchildren. Before the Revolution if one asked the price of a great farm in Mexico he would be told $\$ 100,000$, for example, which would include not only the land and the houses, but the peons on the land. That is, one would buy their debts and in that way 'would practically buy the workmen themselves.

There are farms in Mexico which it takes all day on a railroad train to go through. The Mexican census of I9Io 
showed that 7,000 families own nearly all the fertile soil of that country. The total area of the country is 757,000 square miles, so these estates must average over Ioo square miles each. The Terrazas estate in Chihuahua contains some I3 million acres, an area as large as Holland and Belgium combined. There is an estate in Yucatan said to contain 15 million acres. The peons on these estates received formerly twelve and a half cents gold a day and were kept in debt so that they might be compelled to remain on the place.

The treatment of the Yaqui Indians is a good illustration of how the Indians generally have been deprived of their lands. Their lands had been held in common since time immemorial, their rights recognized by all, with no idea of such a thing as a formal title. The Diaz Government passed a law requiring registration of written titles to all land owned. Since the Indians had no idea of such titles, the creoles took advantage of their ignorance and denounced their lands. The Diaz Government not only recognized this denunciation, but often sent soldiers to drive the Indians off the land. In the case of the Yaquis they did worse, carrying them off by the trainload to work on the big haciendas of Yucatan.

In Argentina there are 12,000 tracts of land, containing from 25,000 to 62,500 acres, and I,000 which contain more than I25 acres. In Chile the tillable soil is held by seven per cent. of the population. The ramifications of this evil run out into the economic, political, social and religious life of the people in a way that makes it impossible entirely to solve other problems until this great problem is met.

\section{THE PROBLEM OF CASTE}

From what has been said about the land problem and peonage, it is easy to deduce the fact that in general there are only two great classes in Latin America-the extremely poor and the extremely rich. The great cosmopolitan centers form exceptions to this rule, but, generally speaking, there is no middle class. Jonathan Swift said that society was like beer in that there were three parts, the top, the 
froth; the bottom, the dregs; the center (the middle class), the real strength. To the development of a middle class must the energies of the leaders in government and education be given.

\section{SUFFRAGE}

This matter is wrapped up in questions of illiteracy and others cited. Calderón says: "If these republics persist in a magnificent continent their failure will be explained not by the poorness of the soil nor the hostility of conquering people, but by the mediocrity of their politicians."

Argüedas' view is that "The great problem, almost the only one, is to nullify these three elements which fatally cooperate to oppose the development of the country: (I) the excessive immorality and lack of training of the government class; (2) the thorough corruption of the classes governed; and (3) the nullity of the indigenous, the numerically preponderant, group."

Manuel Ugarte says: "What first strikes one in the New World is the contradiction between the loftiness of the constitutions and the baseness of the political life. The right to vote, which is the foundation of our social contract, proves almost always a delusion, because governments or parties substitute their wishes for the will of the people by means of fraud or revolution. *** X and $\mathrm{Z}$ declaim in resounding periods terminating in 'liberty,' 'progress,' or 'constitution,' and we take sides with one or the other, for no apparent reason, as we choose head or tail in a game of chance. *** In South America the time has not yet come when ambitions are supported by doctrines. The contest is brutal and open among those who want to occupy the highest post. And as in a proud people, among whom the greatest insult that can be inflicted on a citizen is to call him 'adulador,' those who aspire to rise are many, the fact may be accounted for that civil war has been until recently a national function."

\section{IMMIGRATION}

There are many Spanish Americans who fear immigration, lest they be robbed of their Latin spirit and culture, 
F. García Godoy comments favorably on this fear expressed by various authors, as follows: "The fundamental conception of nationality in some of the republics, due to the direct influence of the ethnic elements that make up the great mass of immigrants, is so penetrating the mass that it is gradually destroying the national sentiment, which is the only thing that gives personality to the peoples of Spanish civilization."

Others, however, believe that only in the blending of the right kind of new blood with the present inhabitants, will they be able to solve their problems. What should this hlood be? Many argue that Latin Europe only can supply the desired elements. Others believe that the Anglo-Saxon immigrant would bring those sterling qualities of sternness, sacrifice, determination, thrift and honesty which are the greatest need of the Latin American. As Le Bon says: "That which the struggle with nature is not able to create, the crossing of the races will realize. This is the only infallible means that we possess of transforming fundamentally the character of a people. For only inheritance is powerful enough to fight against inheritance."

Simon Bolivar, always keen in his appreciation of the difficulties facing the newly liberated countries, was the first to insist on the need of immigration. He said:

"We ought to induce immigration of the peoples of North America and Europe, in order that they may settle here and bring us their arts and sciences. These advantages, namely, an independent government, free schools and intermarriage with Europeans and Anglo-Americans, will totally change the character of the country, and will render it well-informed and prosperous. $* * *$ We lack mechanics and agriculturists and it is these that the country has need of to insure advancement and progress."

\section{Alberdi says :}

"To fuse races, to transplant living civilization by means of a current of immigration, is to create the civilization of new peoples. $* * *$ Civilization, like light, causes the buds to burst forth. 
"Without a large population, there is no development of culture; there is no considerable progress; all is mean and small.-Every European who comes to our shores brings us more civilization in his habits than many books of philosophy.- If the Argentine is a tyrant, death to the Argentine; if the foreigner is a liberator, glory to the foreigner; the throne goes to ideas, not to persons."

Already the problem of assimilating the immigrant is being felt in countries like Argentina. Unlike most Latin American countries her population is made up almost entirely of European stock. About half of the pure whites in Latin America live in Argentina and Uruguay. The few Indians that remain are now found entirely separated from the rest of the population, inhabiting only the Chaco in the north and Patagonia in the extreme south. Argentina is doing for the old European Latin races what the United States has done for the old European Anglo-Teutonic peoples. Ninety-two per cent. of the foreigners of Argentina are Latins, Italians and Spaniards predominating. The melting pot boils here south of the equator with as much fervor as it does in the United States. In 1913, 225,000 foreigners entered the country. There are a half million Italians in Buenos Aires alone. The influence on the Argentine language and culture is already considerable. Temperamentally the Italian influx easily relates itself to its Latin cousins.

A much more serious question is presented in the German and Japanese immigration. There are already half a million Germans in southern Brazil, a large colony in southern Chile, and some 25,000 connected with commercial enterprises in Argentina. Their influence in Central America before the World War was seen everywhere. Not only have they built up solid communities, which represent little Germanies, transplanted root and branch, but in every colony in South America their separate schools were to be found, conducted entirely in German and subsidized directly by the Kaiser. The purpose of all this is now only too plain. While their political aims have been stayed they 
still plan for commercial supremacy and look to Latin America as an inviting field for their activities.

When Count Okuma was asked about the future home of the surplus population of Japan he replied: "South America, especially the northern part, will furnish ample room for the surplus of our population."

The recent discussion in the United States Senate concerning Mexico's ceding certain privileges in Magdalena Bay to a Japanese colony suggests this problem from a different angle. One finds little reference to the Chinese in the discussion of immigration, but, traveling through these countries, he realizes they must be taken into account. In Mexico they already own a considerable number of the hotels, several banks, farms, and the most modern interurban trolley. In Panama the Chinese entirely dominate commercial life. In Cuba they not only do the washing, but much of the labor in the sugar districts. In Lima they have erected a joss house in the very shadow of the cathedral. The Chinaman, of course, lives by himself and is far from understanding the political conditions of these countries.

Ross estimates that unless there is adverse legislation South America may easily be the home of twenty or thirty million Orientals by the end of the century. He further suggests that this might have three results: (I) Forestall immigration from Europe, which South American statesmen are counting on to help key up mestizo unprogressiveness and misgovernment. (2) Large areas of South America might cease to be parts of Christendom, if some of those republics become as dependent on Asiatic power as Cuba is on the United States. (3) Seal the doom of the Indian, who could make no effective stand against the hard-working, close-fisted Oriental.

This question suggests an interesting problem that might be put up to the United States as to whether we would apply the Monroe Doctrine to help keeping out oriental immigrants.

The largest problem of immigration, that is assimilation, is recognized by only a few leaders. Ambassador Nabuco, speaking at the University of Chicago, well said: 
"Take one common point in our destiny. We must all be immigration countries. But in order to be able to oppose foreign immigration with a national spirit capable of turning it quickly into patriotic citizenship, as you do, the assimilating power of the Latin organism needs everywhere to be much increased. Immigration countries must have the necessary strength to assimilate all they absorb. Intercourse with you would teach the other American countries the secret of winning over the immigrants that come to them and of attracting them in larger numbers. That would be by far the most useful knowledge they could receive, because when they knew and succeeded in transforming into true citizens their immigrants, the great national problem would be solved for each of them. To understand that they must all be immigration countries and to create the proper immigrant-habitat, they need to study immigration in your laboratory."

\section{SOCIAL PROBLEMS}

The extent to which marriage is ignored is one of the most noticeable social phenomena of Hispanic America. The Peruvian statistician Fuentes states that $5 \mathrm{I}$ per cent. of the births of Lima are illegitimate or "natural," and adds that "a shocking proportion of the people avoid marriage and live in a complete libertinage which increases as one descends the social scale." In Bolivia 28 per cent. of the army recruits in 19 Io were born out of wedlock. In all Chile the percentage of illegitimate births is given as 38 per cent., but in cities it runs much higher, 57 per cent in Concepción, for example. In Paraguay the census of I9ro shows 6,038 legitimate births and 8,387 illegitimate; that of $1913,6,739$ legitimate and 9,638 illegitimate. Ross says :

"Save in pietistic circles, continence before marriage does not seem to enter into the masculine ideal of the South Americans. Without exception the physicians and educators questioned agreed that all young men sow their wild oats. Outside of Chile it is hardly a matter of blood, for in point of sensuality the Indians of Ecuador, Peru and Bolivia do not seem to differ in endowment from the Span- 
iards. The fact that sex is an overmastering concern in males from puberty on may be attributable in part to climate. There is, indeed, very unequivocal evidence that, irrespective of altitude, the human organism in the tropics is affected in ways adverse to the moral standards wrought out in the lands of the slanting sun. Then one must allow for the factor of early contamination. Throughout tropical South America the mother of the better classes does not care for her children herself but turns them over to native nurses and servants, so that the obscenities and low standards of the ignorant servile element are emptied into the minds of even the children of the ruling caste. Add to this the easy accessibility of the chola and it is clear why in these countries it is well-nigh impossible to keep any life current free from pollution from below.

"Another reason why young men 'think and talk of nothing but women,' why they listen with polite incredulity to an account of the relations between the sexes in the United States and regard our moral tone as pure hypocrisy, is the bareness of life, the paucity of things to do. With us athletic games, sports, camping, scholarship, public discussion, political reform, social work, business and travel compete with the sex interest and aid men to control it. If life presented more interests to the young South Americans, their morals would be better. It is strange that such a flank attack on evil does not seem to have occurred to their spiritual leaders. From the pulpit one hears perfervid denunciations of sensuality, but the preacher can suggest no remedy but the conquest of the sensual man by the spiritual man, while virtue is presented as a sheer dead lift against the downward pull of one's own nature. He might well take a hint from the Yankee educators in Bolivia, who keep their boarding-school lads straight by the simple expedient of crowding the day so full that they have not time for naughty thoughts."

With regard to sex education and vice regulation but little has been done, although both Brazil and Argentina have taken the first steps in this direction. Among these have been efforts to suppress the publication of obscene lit- 
erature and its transmission through the mails. Here and there medical men are being heard and are appearing in print and supporting the continent life as consistent with health and virility. For generations the youth have been instructed to the contrary, as most of them are still. The double standard of morality for men and women is generally accepted by both sexes. The great municipalities continue to put their faith in such discredited devices as segregation, police licensing, medical inspection and other futile measures now being repudiated and abandoned in North America and in Europe as both unChristian and contributory to the harm and misery they are designed to remove.

The presence of many foreign women of ill-repute in the larger ports, in some inland cities of the east coast and in others north of Panama, confirms the belief in the universality of the "white slave" traffic. Efforts to mitigate this form of commercialized vice are reported from Buenos Aires, where the National Vigilance Association, of London, maintains a representative.

As this is being written there has arrived in the United States a deputation of medical men from Chile who have come to study modern methods of venereal disease control. They state that venereal disease enters into the medical history of about 80 per cent. of the men of South America, with practically nothing being done so far for its treatment or for prevention by educational methods. Señor Santiago de Toro H. says: "Chile needs the educational and publicity methods that have been of such value in other parts of the world, and I am certain that we shall receive assistance from social hygiene agencies in this work."

Alcoholism is one of the most pressing social problems in Latin America, acutely so in Chile and certain other areas. Its ravages are worst among the Indians and mestizos of Mexico, Peru and Chile and the lower classes in all the countries. There is a most remarkable temperance movement now gathering headway, however, backed by strong local organizations in Mexico, Peru, Chile, Uruguay and Argentina. Impressed by the "going dry" of the IJnited States and Porto Rico, advanced legislation has 
been passed in a number of countries during the last few months, and there is every indication that sentiment in favor of restriction will grow rapidly.

The general principles of the preservation of public health, outside of the larger centers, are largely ignored. Open sewers abound, if, indeed, sewers exist at all. Markets are held in open places without shade, food being laid out upon the ground for sale amid swarms of flies. City water supplies are open to easy contamination, while no effort is made to get rid of mosquitoes, flies or rats until the yellow fever or bubonic plague has made its actual appearance among the people. Typhoid and smallpox are prevalent and often take fearful toll. The hookworm disease is widespread and leprosy spreads its poison farther every day. In many cities there is no isolation of contagious diseases and little attempt made to prevent tubercular persons from spreading their disease throughout the community in which they live.

\section{THE ECONOMIC PROBLEM}

The outstanding economic fact in all Latin American countries is the dependence of those countries on financial help from the outside. In the very first days after their independence they began to borrow capital for the development of their natural resources, the building of docks and railroads, the exploitation of mines, and, above all, the financing of their governments. This economic dependence has generally had two effects, internal disorders and international complications.

Political leaders have often sold the remarkable physical resources of their countries for foreign loans. When these funds have been recklessly spent or used as rewards for partisan support, revolutionary movements are able to force the old party out. The reform party needs money to carry out their reform program and new loans are made, being disbursed usually in the payment of the political debts incurred during the party's struggle for the upper hand. Thus foreign loans pile up until the country is practically owned by foreign bankers and the slightest fluctuation of political sentiment in the debtor country immediately be- 
comes a matter of economic as well as political interest in the country that has bought its bonds. Sometimes these foreign creditors are able to satisfy their claims, as did the English in Peru, by means of a holding company (the Peruvian Corporation), which takes over and operates the railways, port works and public utilities. In other instances, as in Santo Domingo and Nicaragua, the result of default is diplomatic pressure which may result in the assumption by the creditor nation of responsibility for the integrity of the debtor.

It would be difficult to say which of the two parties in interest is most to blame for this result. The descendants of the prodigal Spaniards seem generally willing to borrow wherever there is a lender, without trying to cut budgets or wait patiently for normal returns. A new need generally means a new loan. As payment is almost certain to fall on their successors in office they feel no need to worry about the amortization of their bonds. On the other hand, foreigners have been uniformly willing to take advantage of such extravagance, and gamble on getting payment in part, at least, through extraordinary rates of interest. Ex-President Wilson says :

"There is one peculiarity about the history of the Latin American states of which I am sure they are keenly aware. You hear of 'concessions' to foreign capitalists in Latin America. You do not hear of concessions granted to foreign capitalists in the United States. They are not granted concessions. They are invited to make investments. The work is ours, though they are welcome to invest in it. We do not ask them to supply the capital and do the work. It is an invitation, not a privilege; and states that are obliged, because their territory does not lie within the main field of modern enterprises and action, to grant concessions are in this condition, that foreign interests are apt to dominate their domestic affairs, a condition of affairs always dangerous and apt to become intolerable. $* * *$ They have had harder bargains driven with them in the matter of loans than any other peoples of the world. Interest has been exacted of them that was not exacted of anybody 
else, because the risk was said to be greater, and thus securities were taken that destroyed the risk-an admirable arrangement for those who were forcing the terms. I rejoice in nothing so much as in the prospect that they will now be emancipated from these conditions, and we ought to be the first to take part in assisting in that emancipation."

The relation of the actual value of the ordinary foreign claim to the amount demanded is illustrated by the following table of the Venezuelan claims and the amounts finally awarded by the International Commission after proper investigation:

Table of Awards and Claims.

(A Bolivar is worth about 20 cents in gold)

Claims

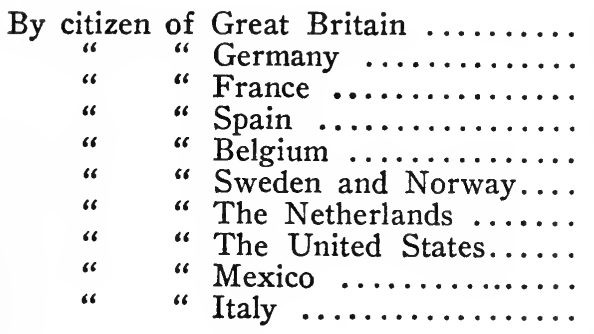

I 4,743,572

$7,376,685$

I $7,888,512$

$5,307,626$

I $4,921,805$

$1,047,701$

$5,242,519$

$81,410,952$

$2,893,040$

$39,844,258$

$190,676,670$
Awards

$9,401,267$

$2,091,908$

$2,667,079$

I,974,8 I 8

$10,898,643$

I 74,359

544,301

2,3 I 3,7 I I

$2,577,328$

$5,785,962$

$38,429,376$

Honduras may be taken as an example of the extremes to which this dependence upon foreign capital may lead a nation. One of the first loans was floated in Europe in I866 for a face value of 5 million dollars. The bonds were issued at 60 , bore ten per cent. interest, and the proceeds were supposed to be used in the building of a railroad. But the railroad was not built. The whole scheme was publicly denounced in the British parliament. Not over $\$ 250,000$ of the original 5 million ever reached Honduras. This sort of thing was worked so often on a weak people that her present foreign debt is somewhere between I 50 and 200 million dollars - no one knows how much, as several experts have said that it is impossible entirely to untangle the country's finances. United States bankers and diplomats 
have recently made several efforts to fund this debt and pay off the English creditors. A treaty similar to the arrangement in force with Santo Domingo was proposed by the United States in I9II, but it was rejected by Honduras, now becoming somewhat wary of such arrangements. No one believes that the country will ever pay, or should pay, the full amount of its foreign debt. It is practically living on its trade with the United States, even to the extent that United States currency is the common medium of exchange. The immense banana business developed in Honduras in recent years by the United Fruit Company has given the country a new start financially. This company owns and operates its own railroads, port works and plantations, all of which are new assets to the country. Incidentally, it hasn't been bad for the United Fruit Company, which earned $\$ 40$ per share for the I 5 months ending December $31,1919$.

In Mexico the actual foreign land holdings are small in financial significance compared to the foreign control of what has recently become the nation's most important source of wealth-the petroleum industry. According to the United States Bureau of Foreign and Domestic Commerce, 97 per cent. of the oil industry is controlled by foreigners :

"Of the total investment in the oil industry of Mexico, 97 per cent. is held by foreigners. In the petroleum industry of the United States but 4 per cent. of the total amount invested is held by foreign capital. In I9I 8 there were 27 companies in Mexico which produced oil in commercial quantities, I 7 of these being owned by Americans, 5 by Spanish-Mexican capital, 3 by Dutch, and 2 by British interests. Of the total of $63,828,326$ barrels produced in Mexico in 1918, the American interests produced 73 per cent., British 2 I per cent., Holland 4 per cent. and SpanishMexican 2 per cent. In 1919, however, the British interests materially increased their production. Only American and British interests shipped oil from Mexico during 1918, the oil exports having been 79 per cent. American and 21 per cent. British." 
The Doheny companies, which have led in the endeavor to direct the United States government's policy toward Mexico in recent years, recently added to their 600,000 acres another 600,000 , giving this group alone the control of more than a million acres of valuable land. Senator Albert B. Fall, in constructing his argument for intervention in Mexico, said in his recent report to the United States Senate that the total value of Mexico's wealth was $\$ 2,434,000,000$, of which $\$ 1,057,770,000$ is owned by Americans and $\$ 584$,000,000 by other foreigners. Senator Fall himself is of the opinion that these are minimum figures, and that the total American holdings probably amount to $\$ \mathrm{I}, 500,000,000$. Certainly this would seem to furnish some justification for the adoption by Mexico of the policy of "Mexico for the Mexicans," an idea which has proved so offensive to a number of American interests.

The immense holdings of foreigners in Mexico, secured largely under the Diaz government, were chiefly responsible for the dissatisfaction which in Igro caused the Mexican people to revolt. According to data furnished by the General Agrarian Offices to the Mexican Ministry of Fomento, that part of the territory of Lower California in the hands of foreigners constitutes about two-thirds of that territory, these holdings being equal in extent to the area of Cuba and Porto Rico combined. Many of these grants were made to companies which volunteered to make the surveys themselves and lay out their own boundaries. Traditional engineering accuracy suffered to such an extent under this arrangement that the national government recently requested authority from Congress to use the national credit to the extent of $50,000,000$ pesos in an effort to recover a large part of these grants. According to a report in a semiofficial government organ, The Mexican Review:

"From data obtained, it seems that something similar to what came to pass in Lower California and Chihuahua also occurred in the states of Sonora, Sinaloa, Tamaulipas, Durango, Guerrero, Tepic Territory, and Vera Cruz, and if the work of the boundary surveying companies did not flourish in the central states it was only because that part 
of the republic which produces grain was already in the hands of leading national landholders.

"In Quintana Roo, the territory of which is thickly covered by extensive forests, I,550,000 acres of land were granted to a single company, and a like thing happened in Campeche, Tabasco and Chiapas, where the greatest extent of territory is deeded to a handful of companies, mostly foreign, notwithstanding the legal prohibition against foreigners acquiring immovable estate within the roo kilometers ( 65 miles) which constitutes the border zone.

"Through concessions, foreigners have become possessed of $54,874,557$ acres of land within the National Territory, or approximately an area equal to that comprised by the following European countries combined: France, Spain, Portugal and Switzerland.

"The following are the grantees of the Territory of Lower California: Luis Huller, with $13,487,473$ acres; Adolfo Bulle, with $1,755,660$ acres; Flores Haile, with 3,74I, 138 acres; Pablo Macedo, with 4,489,6I 5 acres; and Guillermo Andrade, with 893,750 acres.

"In Sonora: Samuel Wood, 565,920; Sonora Land Co., 3,505,308; C. W. Campbell, 315.300; W. Hennings, 44,393; Camou Bros., 403,630; Whiller Land Co., I,333,383; Land and Cattle Co., 280,795.

"In Chihuahua: Palomas Concession and minor grants, 2,706,265 acres.

"In Coahuila: Boertoni Concession, 664,420; B. Williams, 291,188; Milmo de Helli, I,040, I98; Milmo de Radziwill, 373,065 .

"In Tamaulipas: Scott Concession, 875,000 acres, and minor extensions, 6r, r ro acres.

"In Chiapas: Chiapas Mex., Ltd., I,61 7,163; López Bru, Marquis of Comillas, 356,053; Bulnes, 3 I I,825; minor extensions, 407,980.

"In Quintana Roo: Faustino Martinez Concession, I,748,845.

"In Guerrero: Anglo-Mexican Land Co., I,662,803; J. Cardenas, 705,510.

"In Sinaloa: Sinaloa Land Co. and minor concessions, 92,453 . 
"In Nayarit: Luis Gayou and minor extensions, 338,2 I 5 acres."

It was pointed out before that political idealism, constantly maintained against all odds, is one of the great assets of Latin America. It is very clear, however, that the realization in practice of this ideal of self-government and independent sovereignty is dependent upon the ability of these nations to become economically independent by a process of self-denial and the assumption of the responsibility and risk of developing their own resources.

\section{EDUCATION}

Education in Latin America was from the beginning under the control of the Church, which has carried out the medieval practice of confining it to the few who were supposed to possess superior intellectual ability and to those of wealth, high social position and influence. Since these republics secured their independence, education has generally been brought under the control of the government.

Higher education in some centers is well developed, but primary education has not received the attention it deserves, and opportunities for even primary instruction are lacking to the great majority of the people. "Popular education has progressed slowly in most parts of Latin America because of overwhelming indigenous populations, precarious finances, sparse settlement, troubled administrations and persistent opposition of powerful groups." The prosperous and ambitious have sought and gained education as becoming and necessary to their position. The Indians and other poor, as elsewhere, do not want an education because they do not see the use of it. In some considerable areas it might require Ioo square miles to assemble enough children to justify the maintenance of a school. Liberal minded leaders advocate education for all, but selfish taxpayers often intervene. The upper classes, as a class, have conceived their interests to be best conserved by keeping the peon laborer ignorant, helpless and submissive. The priests have also resisted teaching by the state and have not pro- 
vided for it themselves with any measure of universality. They have taught the common people the doctrines of the Church only, apparently sharing with the wealthy classes the belief that no good can come from education of the masses.

Illiteracy, therefore, is stifling national development in practically every Latin American country, the percentages ranging from forty to eighty per cent. In Argentina it is said that forty per cent. of persons six years of age and older are illiterate; in Bolivia eighty per cent. cannot read; in Brazil eighty per cent. are illiterate; in Chile sixty-three per cent.; in Colombia, Venezuela and Peru over eighty per cent.; in Uruguay forty per cent. of persons six years of age and older. In Mexico about seventy per cent. are unable to read or write, and in Costa Rica about seventyfive per cent. Of course it must be understood that most of these figures, while taken from government reports for the most part, are only approximate-as the Latin would say, "poco más o menos."

Latin America had one in twenty of its population in schools in 1912, while Germany had one in six and Japan one in seven. In Colombia, about one person in twenty-two is attending school. In Ecuador, where one in sixteen is receiving instruction, the 800,000 Indians who form about one-half of the population are getting practically no education at all. While landowners are required by law to provide a school if ten or more families are employed on an estate, the law is generally evaded. In the large Indian population of Peru, also, a mere eighteen per cent. of the children of school age are actually under any sort of instruction. Here it is estimated that two-fifths of the children live in districts so remote that the state cannot reach them. The Bolivian government sends out traveling teachers to spend a brief time in each village of the more remote sections, but only one in forty of her population is in school. The Central American group has three per cent. at school, Cuba ten per cent., Porto Rico twenty per cent. Chile, probably more aggressive educationally than most of the Latin American countries, out of a total population of $3,459,95$ I had 331,636 pupils in the elementary schools 
and 39,198 in the secondary schools. School buildings are crowded and many children are turned away because of lack of equipment. Argentina has developed her schools along more democratic lines and about one-tenth of the population is in the elementary schools.

In some sections the Argentine Government is extending education by the provision of portable school buildings, and in that republic every effort is being made to increase educational facilities. The Uruguayan system in efficiency and outreach is second in no respect to that of its larger neighbor. These two nations are said to expend for education a larger proportion of their national revenues than any other countries in the world. The state of Sao Paulo, in Brazil, ranks easily with them, leading the country, which has 635,000 in school out of a population of twenty-four million. Yet the municipality of New York alone spends more on its schools than do all the governments of Latin America. The city of Detroit spends as much annually on its night schools and playgrounds as the republic of Haiti does on its entire educational program.

The educational system installed by the United States and turned over to Cuba in 1902 has greatly deteriorated. Dr. Arturo Montori (Cuba Contemporánea, Havana) puts the blame upon the following factors:

(I) Scanty instruction and defective education of lower classes.

(2) Deficient collective aptitude for economic activity.

(3) Frequent political disturbances.

(4) The evident depression of patriotic feeling in very considerable portions of our Republic (Cuba).

Illiteracy (80 per cent. in I902) is almost eliminated today; but reading and writing is nearly the whole achievement (only I2 per cent. of the pupils get beyond the second grade).

Four common defects must be corrected by the schools :

(I) Economic improvidence-lack of thought for the future; (2) addiction to gambling (excessive in lower classes); 
(3) superstition (among women especially); (4) gross
language (among boys).

Economic education, today almost lacking, should be given in special schools. The upper classes, educated in private schools, are responsible for political disturbances. Patriotism is weakening, as shown by:

(a) Political indifference and avoidance of public life by electorate.

(b) The sale (on a great scale) of land and large individual enterprises to fore:gners.

(c) The demand for foreign supervisors.

The rich are responsible for the first by direct, and the two last by indirect, action. Their indifference has lowered political standards. The remedy lies in bettering all schools.

In 1902 the United States left Cuba this centralized school organization:

The Secretary of Public Instruction, the Board of Superintendents, the Commissioner of Schools, the Board of Education, the Masters.

National idiosyncrasies rapidly transformed the school system into a political machine. The General Superintendent's powers were given the Secretary of Instruction (usually a politician). Provincial superintendents were administration errand boys, not technical men.

A generation, itself uneducated, failed to understand the significance of education (either for the individual or collectively). A politically elected commissioner chose teachers on political, not educational, grounds. The legal oneyear appointments (meant to eliminate the inefficient) became a political weapon. Teachers sought appointments like day laborers. Congress (July I8, 1909) passed a law making a teacher permanent after two years' satisfactory teaching. Political appointees were forced to take the pedagogical courses.

With the organization of the board of inspectors began a disastrous epoch in Cuban pedagogical schools. Politics took the place of teaching. Lecture halls were closed, 
useless books bought, while necessary material was not bought. Examinations for masters were corrupt. The Summer Normal School was suppressed. Resultant scandals led to establishment of normal schools (Act of Congress, I9I5). Simultaneously school salaries were increased, and aspirants for school inspector were required to have had five years' teaching experience.

Adequate buildings are lacking almost everywhere. In Ecuador, for example, all the schools are usually in rented buildings originally erected for other purposes and not adapted at all for school use. In Arequipa, Peru, seventeen schools are in rented private property. Even in rich Argentina many schoolhouses are rented. This condition is quite general throughout Latin America, possibly an extreme case being Venezuela, where in all her history there has never been a single building erected for school purposes with the exception of the government military academy.

In Paraguay education has made great strides compared to conditions in 1870, when there were less than 1,000 children in school in the entire republic. By 1902 this had increased to $24,75^{2}$ and in I9IO to 52,200 , while the I9I6 statistics show I,047 schools manned by I,48I teachers and having 80,I42 pupils. There is little tendency among the people to give their children more than the bare requirements necessary to class them as "literate," as is shown by the figures for the city of Asunción, where out of 7,000 children enrolled in the city schools some 4,500 are in the first grade and only 95 in the sixth.

Teachers in Paraguay are very poorly paid and often are not much above their pupils in education. One teacher replied to a parent who wished his boy to have a knowledge of decimals with the question as to how long the parent. thought he would remain a school teacher at ten dollars a month if he knew decimals himself.

Every friend of Paraguay will sympathize with the following appeal in a book, The Pain of Paraguay, by a Spaniard who has spent many years in the country: "It would be a fountain of incalculable redemption, here above all places, to send into the country a heroic regiment of one hundred teachers, full of sympathy, capable of gaining the 
love of the children, consecrated to the task of sowing in these young hearts the seed of sincerity and liberty of ideas. But these teachers, are they in Paraguay? Are they in America? Are they anywhere in this great vale of tears?" Bomfin says :

"To proclaim democracy and liberty and at the same time maintain and defend social and political conditions of the era of absolutism, is more than senseless. It is the saddest conceivable thing. Republic, democracy, liberty and ignorance-one might as well build a house on the sand dunes. Human evolution means the progress of the soul, the cultivation of the mind to understand, the cultivation of the heart to love.

"The greatness and extensiveness of our misfortunes is no reason for us to fold our arms. Let us make a campaign against our ignorance. There is no other way to save this America of ours. These expedients and political wisdom have now contributed all they are able to give. That progress which some count by tax receipts, others by the number of ships and others in the extent of mines being worked, not only is badly defined, it is false and illusory. Progress must be made by society in its totality; and this is only attained by the education and culture of each social element. The environment is not bettered without bettering the individual. There is no progress for him who is unable to comprehend and desire it, insist in searching for it. Progress is a triumph-a growing victory over nature, and in the struggle which leads to it the first essential is to free oneself of ignorance, of preconceptions and the discouragement which is to be found within them, to know the enemy, to conquer him, to know the obstacles, to overcome them, to know the resources which can serve, to know the reach of each effort, to know, to know, to know-more and more."

The educational systems of Latin America have been constructed, like their political systems, on a highly idealistic basis. There is absolutely no question of the desire of the leaders to minister to the educational needs of their people. The noticeable defect is on the practical side, in its 
bearing on actual needs and local conditions. In the matter of education, we have an exhibition of what Prof. Ernesto Nelson of Argentina calls "insistence on logic and symmetry." If it is decided that a national college should be put into the provincial capitals, one is placed in an insignificant town where only fifty students are to be had, while some large city which does not happen to be a provincial capital is left entirely unprovided for. The symmetry of the plan could not be spoiled for the sake of the needy city, nor would logical consistency permit the most remote rural capital to be deprived of its colegio.

The educational institutions are often built from the standpoint of the convenience of the faculty, the gratifying of public pride, conformity to a city architectural scheme, rather than to conform to the needs or convenience of the pupils. Many institutions are built simply because of models seen in other countries which have impressed the imagination, to the ignoring of practical adaptability of such an institution to local conditions. Prof. Nelson tells of returning to Argentina from the United States and telling of fine children's libraries there. Immediately the Argentines said they would have them too. They would put up suitable buildings immediately. "But," the professor replied, "the first thing for the library is to have the children's books." They replied, "We have these." "No," cautioned the professor, "the books we have for children represent adult thoughts expressed in children's language. We must study the children themselves and write books that are really children's books; then we will be ready to build libraries for them." This kind of reasoning, however, was very difficult for the Argentines to understand.

Dr. Villaran of Peru says :

"We still maintain the same ornamental and literary education which the Spanish governors implanted in South America for political purposes, instead of an intellectual training capable of advancing material well-being; an education which gives brilliancy to cultivated minds but does not produce practical intelligence; which can amuse the leisure hours of the rich but does not teach the poor how 
to work. We are a people possessed by the same mania for speaking and writing as old and decadent nations. We look with horror upon active professions which demand energy and the spirit of strife. Few of us are willing to endure the hardships of mining or incur the risks and cares of manufacture and trade. Instead we like the tranquillity and security, the semi-repose of public office and the literary professions to which the public opinion of our society urges us. Fathers of families like to see their sons advocates, doctors, office holders, literati and professors. Peru is much like China-the promised land of functionaries and literati."

There is no place on earth where one faces more difficult questions of curricula, discipline and administration. The state education system resembles the French more than the North American, both in its courses and in its fundamental organization. There is no college in the North American sense. From the sixth grade, on the average, though each country differs, the pupil goes into the liceo or colegio civil, which is something like our low grade academy. Most of the work given in our colleges is taught in the first years of the professional schools in Latin America, which, instead of having three to five years, generally offer a course extending through seven years. The question of how better to bridge the gap between the liceo and the professional school is now giving much concern to educators. Another problem is the one of choice between two radically different theories of education or of making a happy combination of the two.

North Americans are accustomed to a system which is designed to develop the freedom of the individual student, who is allowed to select his own courses very largely and choose his own way of mastering the required material, the theory being that liberty is so precious that it is worth while to risk failure or ill-proportioned development in order that each personality may develop along the line of its own nature. But in countries where the Jesuits have directed education for centuries and have stamped their theories and methods so thoroughly upon the thinking of the people, as has 
been the case in Latin America, the theory of rigid discipline rather than liberty prevails. Emphasis is put upon memory and tradition. It means a centralized system of schools conforming to the narrow, authorized curriculum for the masses, and specialized schools for the privileged classes. This results in culture of a kind and a wide range of facts, but a lamentable lack of initiative, self-reliance and original thinking.

\section{THE MORAL PROBLEM}

A greatly increasing number of Latin Americans are coming to the conclusion that the greatest of all their problems are the moral and spiritual ones. Alfredo Colmo says : "These are the defects which I will show are found in the morality of individual Argentines: lack of initiative, lack of punctuality, a continual looking for 'the turn'-that is, how to evade contracts and agreements-and dodging all that places upon one an obligation and a duty."

He continues:

"I will content myself with putting down two sins which seem to be of decisive importance. The first is the habit of lying. This is so general and so intensified that it seems to be a subconscious predisposition, so that there is nothing about which one does not lie. ***

"The second thing is more general. It is a lack of real men. I mean men who have sentiment, will, morality, character, all that makes the individual a force, an efficient driver with energy, honesty and a superiority of aims.

"The work of developing honesty, of making it a religion of the masses and consolidating it with the work of forming men, is the great, I might say the one, national problem. All the rest of our problems are simply a consequence of this one."

Agustin Alvarez says:

"Sarmiento said that the evil which affects the Argentine Republic is its extension. Very well, the republicans have suppressed the extension and unified the country. Now the evil which affects Argentina is the lie. And it is necessary that she work without rest until she succeeds in 
emancipating herself from this detestable South American institution, which is three-fourths Indian and four-fourths barbarian."

To quote Dr. José M. de la Rua:

"The Latin is generally selfish and individualistic. $\mathrm{He}$ does not wish to form part of any society or organization in which he does not see some benefit or practical advantage more or less immediate for himself. He does not know or understand what it is to work for others, hence that class of association which asks his money, work or time without visible and practical returns to himself does not ordinarily get either his interest or his participation. Another defect of the majority of Latins is the lack of constancy. They are easily made enthusiastic over a good idea or a noble purpose, but soon lose their enthusiasm and fall into indifference and apathy."

The following from a well-known Uruguayan author makes the essential connection between problems of morality and problems of religion which has too long failed of recognition in Latin America :

"If we doubt the advantages of Christianity for Latin America, a journey to the United States will do away with that doubt. The North American, though very independent, is yet most obedient to the essential principles of the social life. From the President to the most humble citizen, all recognize the power of the religious idea in the formation and stability of a people. An attentive analysis of Latin American society produces the most disagreeable impression. In the moral and spiritual worlds everything remains to be done. We are distinguished for mental vivacity. We excel in linguistics and the power of assimilation. The upper classes give an example of singular versatility in all lines of knowledge and occupation. But this is not sufficient in a directing aristocracy, which thinks that there does not exist any authority except that of science and reason.

"The Christian culture will always be necessary because 
great thoughts come from the heart. But the majority of our notable men are free thinkers. There exists an absolute indifference to religion. This is true even among the young people, at the age most propitious for inculcating the ideals of life.

"The Latin American child is brighter and more precocious than his northern brother, but in the long run the robust virtues of self-domination, of sacrifice, of patience and will, conquer. Character asks only one aid-good customs to oppose sensuality."

Án artičle in $E l$ Sur, of Arequipa, Peru, in November of I9I4, headed "Ruin," states:

"That which cannot be cured and which foreshadows death is moral failure. And this is the evil of this country. *** We breathe a fetid atmosphere and are not sickened. The life of the country is poisoned, and the country needs a life purification. In the state in which we are, the passing of the years does not change men, it only accentuates the evil. A purging and a struggle are absolutely necessary."

The Vice-Rector of La Plata University, Argertina, in his opening address of the college year, called upon the university to recognize its obligation to develop character in the young men who pass through its halls :

"It is with great sadness that I witness the steady decrease in the number of unselfish, idealistic, genuine men; how engulfing the tide of selfishness, of rebellion, of indiscipline and of unsatiable ambition; impunity so often supplants justice that I fear for the spiritual future of the land of my children, unless we make haste to remedy the great evil, which is disregard for the noble, and the great and unmeasured lust for material riches."

\section{THE RELIGIOUS PROBLEM}

Whatever else visitors to Hispanic America may notice, they are practically unanimous in their observance of the 
lack of religion in those countries. In former times this indifference or hostility to Christianity was noted only among the men of the more cultured classes; $110 \mathrm{w}$ it is spreading to the educated women and in a large degree to the workingmen in the cities. As Prof. G. H. Blakeslee says: "However the religious question is to be settled, it remains today the greatest problem of South America. Until it is solved every South American republic is likely to witness from time to time such scenes as those recently enacted in Chile, where crowds of its best educated young men marched night after night through the streets of its capital city deriding, mocking and insulting the Church to which the nation belongs."

The demonstration to which reference is here made is that in Santiago and Valparaiso where the university students went on strike against the activities of the Papal Nuncio. For almost a week they kept those cities in a ferment, completely disorganizing university arrangements by their refusal to attend classes and by other acts of protest. The object of the agitation was to bring pressure on the government to send the Pope's representative out of the country. Joining with the students, a crowd of citizens estimated as high as 50,000 gathered in Santiago and petitioned the President of Chile for the deportation of the Nuncio. Each night during this somewhat hectic week witnessed parades of protest or mock processions and ceremonials ridiculing religious rites. This extension of the people's enmity from the person of the Nuncio to the Church itself was easily accomplished in the tense state of public feeling. In one of these mock processions two large figures were carried by the marchers representing in no flattering way a monk and a nun. Other processions were made up of students robed as priests, carrying swinging censers and followed by a crowd of young men dressed as penitents, with lighted tapers in their hands. So realistic was this latter feature that one observer reports seeing old women kneeling to them in the streets, unaware of the real character of the marchers. Banners and transparencies attacking the Papal representative, the local hierarchy and the Church itself were carried in most of these processions. 
The public clamor over the matter reached into the Chilean Congress, where it was the subject of lively debate. Strange to say, one of the impelling causes of this outbreak lay in the economic strain under which the South American countries have labored since the close of the war, the specific charge against the Nuncio being that he was sending money realized from the sale of Church property out of the country. Radicals in Chile claim that within the last five years Church officials in Chile have sent to Rome more than a million and a quarter dollars in anticipation of the possible separation of Church and State in that country. This particular charge has precipitated a general scrutiny of the wealth of the established Church. In Santiago alone its property is valued at more than Ioo million dollars and there are some who claim that the income of the Church in Chile is greater than that of the government itself.

While this outbreak came with considerable suddenness out of an atmosphere of almost complete subservience to ecclesiastical authority, it had long been brewing. For years there has been a latent hostility to the Church and the clergy in the minds of educated men in Chile, although it has always been politically and socially expedient to conceal this animosity as much as possible. With this recent agitation it has broken out into the open.

If visitors to Hispanic American countries speak often of the lack of religion in those lands, their own writers almost universally condemn the established Church. Among the numerous references of García Calderón to the subject the following may be cited from his book, "The Creation of a Continent":

"We do not find in Latin America either an elegant skepticism, a puritan religion, or even a mysticism like the Spanish. Her Catholicism is a limited and official religion. We are witnessing the decadence of traditional religion. The Church is being converted into a bureaucratic institution. Its convents attract only those of the inferior classes. The robustness of creative convictions, which is the strength of the Biblical men of North America, the deep interest in human destiny, the stern sense of duty, the realization of 
the seriousness of life, do not disturb Latin American Catholicism, sensual and lymphatic. ***

"In the political and economic order our religious indifference is the cause of indecision in opinions, of hatred of ideas, and of immorality. *** These different republics lack a creed. Their ancient life was linked to a severe religion. The abandonment of Catholicism in democracies without moral culture means retrogression to barbarism. *** In the United States puritanism is the perpetual defense against the plutocratic immorality. In the Latin South only a renovated and profound faith can give to accumulated riches a national sentiment. An American servant of Caliban, without clear ideals, coldly atheistic because of mental laziness or indifference, would be an immense mediocre continent that could submerge, as did Atlantis, without leaving in human annals the memory of a secret unrest, a hymn to the gods, or even a passionate skepticism and tragic doubt."

In an interesting book, "The Plow, the Pen and the Sword," Señor Huerta, of Paraguay, in discussing national problems, has this to say:

"How distinct has been the rôle of religion in Spanish America from that it has played in North America! Since the time of the conquest, when the priests were in such a hurry to administer the sacrament of baptism to the Indians, until the present, religion has not exercised the amplitude of its noble mission outside of the Church building and the congregation.

"Mixing in politics has brought about many evils in the Republic, which has had to suffer the acts and propaganda of the clericals whose fruit has been nothing more than the discrediting of worship and the skepticism of the masses, with grave injury to the young society and its government. It would be easy to cite many honorable and patriotic actions of the Catholic Church and its many educational activities, but as a moral entity it has not been able to escape the materialistic spirit of government with which it has been so closely associated. 
"In Ecuador or Colombia it is impossible to know whether the government is served by the clergy or the clergy is a model for the government. The religious influence has not the merit of aiding the development of these countries, pacifying the ardor of the political parties, but has the effect of exciting them with intolerance and exclusiveness. If, as is the case in the United States and as the psychologists believe, religion is a powerful force for the transformation of human groups into nationality, religion is destined to play a great part in the Spanish American republics."

That the student class is leading the attack on the Church signifies that it is in the college and university centers of South America that religious indifference is most marked and sentiment toward the Church most hostile. For the benefit of North Americans who may be inclined to dismiss the whole matter as a mere student agitation, it must be pointed out that in Latin America, as in continental Europe, the university students are an important political factor and nearly always form the backbone of progressive movements and are active politically. The students, too, have been directed to some extent by political leaders who preferred to remain in the background and not openly appear as leaders in an attack upon the clergy.

A great religious reform is greatly needed in South America. Some of her keenest critics-several of them among her own sons-believe that lack of a strongly developed moral sense is the main thing that stands between the South American and a great future of world leadership and world service. This vital lack shows itself not only in the realm of religion, but in the attitude of the people toward their work, in their political life, and in their social relationships, particularly in the relations between the sexes. A spiritualized Church should surely do something to bring to these peoples a stronger sense of duty and right and a greater stimulus toward allowing this sense to govern their lives.

It remains, then, for these southern nations to discover a religion that is compatible with true democracy and modern scientific knowledge, which will at the same time build 
up personal and national character and furnish those spiritual ideals without which no permanent cultural edifice can be built. What form shall this religion take? Many believe with Garcia Calderón that it must be a reformed $\mathrm{Ca}$ tholicism. He says :

"Protestantism is not, however, the religion suited to these democracies, submitted to a three-century Catholic discipline. The race has lost its ancient individualism which inclines toward Protestantism, and austere Calvinism or Puritanism is out of the realm of tropical imagination and Castilian sensuality. The religious renaissance can only be realized within Catholicism, a traditional religion, mother of ideas and customs, a powerful force that cannot be escaped by either the servile Indian or the Spanish hidalgo."

On the other hand, there are not lacking other great Latin Americans who believe that the simple, democratic Evangelical Christianity is the greatest need of the south. Agustin Alvarez says:

"Thus liberal Protestantism, leaving to man his best aptitude and amplitude for lay progress, has formed the colonizing races which, by their greater resources dominating nature and exploiting the soil, have enriched and extended themselves to all continents. In the same way Catholicism, repudiating profane science, and captured by attention to public worship, has separated the best energies of man, has withdrawn him from improved methods of agriculture, commerce and industry, from personal cleanliness and public sanitation, from earthly justice and civil morality.

"The mother country did us greater harm by prohibiting in America the cultivation of ideas and the sentiments of tolerance than it did by prohibiting the cultivation of the vine and the olive. If the primary cause of the progress of man is the thought which modifies his sentiments and forms his character, a man limits his progress to the degree to which he limits his thought. So the fundamental cause of the backwardness of Spanish America, and of Spain itself, is the restriction of thought by an absurd religion.

"Thus narrow and superstitious Catholicism, the open 
enemy of science and the advocate of lay ignorance, develops a spirit incapable of self-government because it is educated in dogmatic intolerance and spiritual slavery, which are the spiritual father and mother of this Spanish perverseness which we knew in 1810 and the Cubans knew in Igoo. In the same way liberal Protestantism develops those spirits with self-rule, tolerant in action because they are educated to be tolerant in thought."

Alberdi, one of the greatest thinkers Argentina ever produced, was firm in his conviction that Protestantism is the religion for republics. Juarez, the greatest of Mexicans, said that upon the development of Protestantism in Mexico largely depended the future of his country. President Alessandri, of Chile, recently said, on the occasion of being presented with a Bible by evangelical workers in that country:

"I am a Christian. I believe in the doctrines of Christ. I accept the sound doctrines of the Bible and reject errors of the Roman Catholic Church. I raise the white flag to all truth. This book of yours which you present will remain by my side. It will be my guide and I shall know how to appreciate it at its true worth. If Congress confirms my election, when I come into the capitol I will work incessantly for complete and absolute liberty of conscience. I know of the cultural and moral work that you, the evangelicals, are doing in all the republics and I hold it in the highest esteem. If I enter the nation's capital the doors will always be open to help every good work which you do and you will always occupy a place in my heart."

The presidents of Guatemala, Ecuador, Bolivia, Mexico and Argentina have officially invited North American evangelical missionaries to their countries. Evangelical schools are often patronized by the leading citizens of the community and government subsidies are frequently offered them.

There now exist many self-supporting evangelical churches, entirely directed by nationals who are recognized as strong forces in their communities. In Rio de Janeiro one such church counts among its thousand members prominent lawyers, engineers and members of Congress, raises 
an annual budget of $\$ 15,000$ and is active in many community philanthropies. The number of evangelicals who have taken prominent part in the Mexican Revolution and are now conspicuous in the reconstruction of the country, particularly along educational lines, is very large. The paper published unitedly by the evangelical churches in Porto Rico has the largest circulation of any periodical on the island. City-wide campaigns in which prominent business and professional men of the community furnished the leadership have recently raised hundreds of thousands of dollars for Y. M. C. A. buildings in Montevideo and Rio de Janeiro.

The problem of a vital religion for Hispanic America will probably be solved not by an unquestioned loyalty to either a cold New England Protestantism or a narrow, other-worldly Catholicism. In the short time since Protestantism was introduced into these countries it has had a liberalizing influence on the Catholic Church. On the other hand, Protestantism, as it establishes itself in the South, is being transformed by the warm, sympathetic temperament of the Latins into a much less rigorous and austere faith. No doubt these two divisions of Christianity will mutually react upon each other with a resultant gain to the people. The defeat of both would come, and sadder yet, the people would completely lose the fruits of real spirituality, if these two creeds should waste their energies in fighting one another instead of giving themselves to working out, as discussed in this chapter, the great racial, moral, economic and social problems with which these lands of sunshine and shadow are so threateningly confronted.

There is no doubt that the best elements of Latin American life are seeking earnestly to solve these problems, which together make up the greater problem of providing an adequate religious dynamic for the peoples of the South. As Dr. Abel J. Perez of Montevideo says :

"Another of the factors which in the most fundamental way can cooperate to secure to the American citizens an elevated culture as beautiful as it is sane, which would give a high and invariably moral ideal, making possible the soli- 
darity which is pursued as a high purpose of its collective existence, is the adoption of a religious creed so pure that it can protect in its sanctuary all the most noble aspirations; so ample that in it are found all creeds; so tolerant that in it all the faithful may mix their prayers-an indispensable complement of popular education, a factor of resistance and energy that will bring to a realization the exalted objects of the young countries of America.

"What I desire is to reserve for the child in the school this shield (religion). I wish to leave him this treasure of resistance which shall maintain his faith, tone up his enthusiasm, give him absolute possession of himself, assure to the future warrior the harmonious integrity of his activities which the collective life of America imperatively demands."

\section{Sources of Further Information on Problems of Latin America}

Alberdi: Bases para la Organización de la República Argentina. Alvarez, Agustin : ¿Adonde vamos?, "La Cultura Argentina." Arguedas, Alcides: El Pueblo Enfermo.

BARRETT, RAFAeL: El Dolor Paraguayo.

Blakeslee, Geo.: The Outlook, Vol. 120, p. 379.

Blanco-Fombona: Evolución Politica y Social de América Española, El Hombre de Hierro.

Bomfin, M.: A America Latina.

Bulnes, Francisco: El Porvenir de las Naciones Hispano-Americanias.

Bunge: Nuestra America.

Calderón, F. García: La Creación de un Continente, Latin America, Its Rise and Progress.

Colmo, Alfredo: Los Países Latino-Americanos.

Galdames, Luis: Educación, Económica e Intelectual.

García: La Ciudad Indiana.

Huerta, Cardus: Harado, Pluma y Espada.

Matto de Turner, Clorinda: Aves sin Nidos.

Mendieta, Salvador: La Enfermidad de Centro America.

Perez, Abel J.: "America."

Reports of the Panama Congress on Christian Work.

Rodo, J. E.: Ariel.

Ross, E. A.: South of Panama.

SARMiento: Fecundo (English translation).

SpeEr, R. E.: South American Problems.

Ugarte, M.: El Porvenir de la América Latina.

Zúmeta, Cesar: El Continente Enfermo. 


\section{Chapter III}

\section{EARLY EFFORTS TOWARD PAN AMERICANISM}

THE BOLÍVAR IDEA

In the former chapters we have drawn up the balance sheet of Latin America. We have looked at her wonderful possibilities based on her physical, intellectual and spiritual resources. We have also taken into account, on her debit side, the great problems which she is facing, and which she must solve before taking a place of leadership among the nations of the world. With these considerations as a background let us raise the question of how all of the Americas may develop among themselves close cooperation, and then build up a real continental solidarity. First of all let us look to the past, and examine the historic attitude toward one another of both the United States and the southern republics. It is not necessary for us here to cover the historic differences in the origin and colonial life of North and Hispanic America. These are amply treated in many books. What we propose is to trace the spirit of unity which, in spite of all the divisive elements and selfish purposes prevailing in all the American countries, has been conspicuous since the beginning of the movement for independence of these countries from Europe. This insistence upon American unity by the great leaders of Latin America runs like a thread of gold through all of the turbulent struggle of those nations towards the development of real democracy.

Sentiment has played its part in keeping this idea in the foreground. We must admit, however, that the important reason for its persistence has been logical rather than psychological. The development of Pan Americanism today is peculiarly dependent, therefore, on scientific and historical 
interpretation. The three big facts that caused great Americans like Bolivar, and Clay, and Monroe to think on what we now call Pan Americanism were the geographical fact that all live on a common continent separated from the rest of the world by two oceans; the historical fact that all had emigrated from and been colonies of European nations, and the political fact that all, having gained their independence, had established republican forms of government-governments which were more or less menaced by these European countries, which were as strongly monarchical as America was republican.

We might as well frankly admit that there are two very different peoples living on the American continent, differing widely and profoundly in race, training and their interpretation of life. If we are to trust simply to sentiment, these two peoples will not find themselves particularly drawn to one another. The punctiliously polite Latin depreciates the blunt Saxon, and the practical Saxon finds it hard to be patient with the idealistic Latin. But we must be willing each to allow the other his own place in the American sun, and his privilege to be himself, seeking a common friendship, not because we are especially "simpático" to one another, but because the logic of our position leads to mutual relations. This is not to say at all that we must eliminate sentiment and forego any friendship but a selfish one. But it does mean that a Pan Americanism not based on well understood geographical, historical and political facts, is one that will not stand.

There are three great policies that have guided the American Republics in their international relations since they became independent from the mother countries. First, the Washington principle of no entangling alliances, which kept the United States out of European politics; second, the Monroe Doctrine, which kept the European countries out of America; third, the Bolivar idea, which has advocated the close cooperation of all American republics for mutual development and protection against Europe. While Bolivar and other great South American advocates of continental solidarity have not always been consistent in their inclusion of the United States, nor indeed of Brazil in this unity, Bolivar 
can well be called the father of Pan Americanism, or as it was called in his day, American Union. The most fundamental historical fact, one which is often ignored, in the rise of Pan Americanism is that in the early development of American life, both Anglo-Saxon and Hispanic America were strongly in favor of continental solidarity. This policy of American Unity has been the ideal of the greatest Southern statesmen since the beginning of their independence. We may call it the Bolivar Idea because he was its greatest exponent, not that it was peculiar to him any more than what we call the Monroe Doctrine was peculiar to Monroe. Let us look at the way this idea of unity prevailed in the early days of the Latin American republics.

EARLIEST EXPRESSIONS OF THE IDEA OF PAN AMERICANISM IN HISPANIC AMERICA

In another chapter we will deal with the early desires for continental solidarity as expressed by leaders in the United States. Here we are interested in a brief review of this idea of unity as advocated by Hispanic American leaders.

In 1810 expressions of Pan Americanism were made by the Argentinian, Bernandino Rivadavia, and the Chilean, Juan Martinez de Rosas. Kivadavia in communicating the news of the installation of the first Junta at Buenos Aires, speaks of the union and harmony which should prevail among citizens of the same origin, dependence and interests. In Rosas' "Declaration of the Rights of the Chilean People" we find the following striking statement: "The people of Latin America cannot defend their sovereignty single-handed: in order to develop themselves they need to unite, not in an internal organization, but for literal security against the plans of Europe, and to avoid wars among themselves. *** The American states must unite in a congress in order $\mathrm{tr}$, organize and fortify themselves. *** The day when America, united in a congress, whether of the two continents, or of the south, shall speak to the rest of the world, her voice will make itself respected and her resolve would be opposed with difficulty."

In I8I I Chile and Venezuela aspired to unite the two 
countries, and in that year the Constitution of Chile declared that the American people ought to form an alliance to defend themselves against Europe and to avoid fratricidal wars:

In I818 O'Higgins, the Dictator of Chile, suggested a confederation of all Latin American republics and urged "the great federation of the American continent capable of maintaining its political and civil liberty."

The unity of the Spanish-American states was argued by the Guatemalan Ayos and others of Central America almost at the beginning of the movement for independence. José Cecilio del Valle conceived his beautiful "dream" concerning the necessity of a general federation of the new American states in I824. This received the approval of the National Assembly of Central America which named plenipotentiaries to the governments of Colombia, Peru, Chile and Buenos Aires, to present this idea to them. Not knowing of Bolivar's movement along the same lines, their representative was directed to congratulate the liberator of Colombia on his heroic work for the independence of these countries and to solicit his help in the development of the proposed conference.

The Minister of Foreign Affairs of Central America, in his first message to the Federal Congress, in I825, referred as follows to the Monroe Doctrine and to the friendly relations between North and Central America:

"The existence of the new republics of the continent does not interest these republics alone but also the United States of the north. In that country of liberty were born the institutions which have acted as a splendid example for others to imitate. Any armed intervention on the part of Europe would be directed toward the destruction of these same free institutions and the establishment in America of the principle of a hereditary monarchy, where constitutional acts are nothing more than the expression of their monarchical will. Therefore the United States would find itself equally threatened, and it is for this reason that the President declared in his message to Congress that they would look upon any intervention of a European power directed 
EARLY EFFORTS TOWARD PAN AMERTCANISM 101

toward violating the destinies of independent Amesican governments as a manifestation of hostility towards the United States. This attitude makes the executive power hope that we shall find in the sons of Washington the most decided cooperators or supporters in case our independence should be threatened by European powers. This government, being influenced by these sentiments and desirous of manifesting to the said United States our sincere desires for a reciprocal consideration and mutual friendship and the establishment of commercial relations on bases that will be mutually helpful to each nation, appointed a Minister to the United States, charging him at the same time to carry out certain other useful projects which would be halpful to the cause of independence and the service of the Central American Republic."

Dr. Francisco Castañeda, after quoting this document in his splendid book recently issued, called "Nuevos Estudios," continues as follows: "This was the predominant mode of thought at that time, and the more those statesmen studied the problems of the new American republics the greater was their effort to stimulate union and fraternity."

The idea of Pan Americanism was first suggested in Brazil in 1817 by Cruz Cahinga, plenipotentiary of the Pernambucan Government in the United States. In I8I9 another Brazilian, Rodrigo Pinto Guedes, presented to the Minister of War and Foreign Affairs of Brazil the idea that the only means Brazil possessed of safeguarding herself in the presence of the threats of Europe was an alliance with her neighbors to the north and south, by means of what he called an American League. In 1819 the Brazilian government, endeavoring to carry out this suggestion, sent the following instruction to its political agent in Buenos Aires:

"After you have constantly reminded them that the interests of the kingdom are identical with those of the other states of this hemisphere and that they should participate in our destinies, you will promise on behalf of his royal highness the solemn recognition of the political independence of those governments, and you will explain the priceless 
benefis that may result from their forming a confederation or offensive and defensive treaty with Brazil, in order that, with the other governments of Spanish America, they may bring to naught the crafty wiles of European politics."

In a proclamation to the Peruvians, November I3, I8I8, San Martin expressed the conviction that only by a union between Argentina, Chile and Peru would they be able to inspire in Spain the feeling of her impotence and in the other European powers the proper consideration and respect. This idea was the basis of his sending, as Protector of Peru, envoys to Mexico, Guatemala, Colombia, Argentina and Chile.

Colombia and Peru signed a treaty of alliance in 1822 , which provided the basis of a future league of all the Spanish-American republics, and for the meeting of an Assembly at Panama which would serve to develop intimate relations between the states, an advisor in conflicts and interpreter of treaties. Colombia and Mexico signed a like treaty. These treaties were the first formal expression of the unity shown in the struggle for independence, which was a revelation of the interdependence of the various countries. An Argentine army helped liberate Chile and Peru. Sucre, the Venezuelan hero, won the final triumph of Peru at Ayacucho. Bolivar advanced from Venezuela and freed Colombia, Ecuador, Peru and Bolivia and won the title of "the Father of Five Republics." These treaties really laid the foundation for the calling of the Panama Congress in I826.

Bernardo Monteagudo wrote the first comprehensive "Plan for Federation" in Lima in 1825. This document has taken its place as one of the most remarkable state papers ever produced by a Spanish American. Monteagudo, who was not noted for his virtue, was assassinated soon after producing this document, but no doubt it influenced Bolivar in working out the plans for the Panama Congress. $^{1}$

1 The full text of this remarkable document, along with most of the other documents concerning early attempts at American Union, will be found in a recent publication issued by the Mexican government, called "El Ideal Latino- 


\section{EARLY EFFORTS TOWARD PAN AMERICANISM 103}

\section{BOLIVAR'S INITIATIVE}

It is to Bolivar, as already indicated, that American unity owes its greatest advocacy. Even before independence from Spain had been secured he began working on this problem, as the most important one before the young governments then in the midst of their birth pangs. In writing to the government concerning the campaign in Venezuela in 1813 , he said: "Only an intimate and fraternal union of the sons of the New World and an unalterable harmony in the operation of their respective governments will be able to make them formidable to our enemies and respectable in the sight of other nations." On September 6, I8I5, he wrote his famous Prophetic Letter from Jamaica, where he was in exile, which is filled with this idea, as the following quotation shows:

"The consolidation of the New World into a single nation with a single bond uniting all its parts is a grand conception. Since the different parts have the same language, customs and religion, they ought to be confederated into a single state; but this is not possible, because differences of climate, diverse conditions, opposing interests, and dissimilar characteristics divide America. How beautiful it would be if the Isthmus of Panama should become for us what the Isthmus of Corinth was for the Greeks! Would to God that we may have the fortune some day of holding there some august congress of the representatives of the republics, kingdoms, and empires of America, to deliberate upon the high interests of peace and of war not only between the American nations, but between them and the rest of the globe."

Three years later he wrote to Pueyrredón, Dictator of the United Provinces of Rio de la Plata:

"When more favorable circumstances afford us more frequent communications and closer relations, we shall hasten, with the liveliest interest, to set on foot, on our part, the American covenant which, by forming one political body of all our republics, shall present America to the world with an aspect of majesty and greatness without parallel among 
the ancient nations. America, thus united, will be able to call herself the queen of nations, the mother of republics."

About the middle of I8I9, the Liberator crossed the Andes and freed the viceroyalty of Nueva Granada. Immediately, before the close of the year, he united Nueva Granada and Venezuela in a single state, which he christened República de Colombia. He was soon to incorporate Ecuador with the new republic. He was realizing, in his own way, his ideal of unifying the American peoples. In 1822, he invited the other republics of the continent, in the name of Colombia, to make treaties of alliance, as already stated. He governed Venezuela, Nueva Granada, Panama, Ecuador, Peru and Bolivia. He exercised influence upon the policy of the Argentine Republic, where there existed a strong party in opposition to the government, a party of opposition that sought to lean upon the Liberator; the Argentine government itself sought the aid of the victorious and powerful ruler against Brazil. He offered to Chile a contingent of troops to free the archipelago of Chiloé, still in possession of Spain. On the north he sought to extend his influence to Mexico, to liberate the Antilles, one of which, Santo Domingo, had already declared itself in I82 I an integral part of Colombia.

In December, 1824 , he wrote from Peru his memorable circular addressed to the governments of Buenos Aires, Brazil, Colombia, Chile, Mexico and Central America, in which he insisted upon the immense benefits that would accrue to the young republics from a meeting of delegates at Panama to consider the protection of their institutions. Bolívar said:

"After fifteen years of sacrifices, devoted to the liberation of America, in order to obtain a system of guarantees that, in peace or war, shall be the buckler of our destinies, it is now time that the interests and relations which unite among themselves the American republics, formerly Spanish colonies, ought to have a fundamental basis that shall perpetuate, if possible, the duration of these governments.

So respectable an authority (as that which shall direct the 
policy of these governments) can not exist, except in an assembly of plenipotentiaries, appointed by each of our republics, and gathered under the auspices of the victory obtained by our arms against the might of Spain. The Isthmus of Panama has been offered by the government of Colombia for this purpose by existing treaties." .

Thus came about the first meeting in the world's history to consider the formation of a League of Nations. Because it was not immediately successful, history has given far too little recognition to this remarkable gathering, the idea back of which has struggled for expression a hundred years and must soon triumph.

The Congress was hurriedly called and only the delegates from Colombia, Peru, Mexico and Central America arrived in time to attend the sessions.) There was also present a representative of Great Britain and Holland had an unofficial observer. Chile professed friendship for the Congress, but delegates were appointed too late to arrive. Bolivia's delegates had the same fate. Brazil appointed delegates, but probably her fear that the congress might wish to side with Argentina in their dispute over Uruguay, caused them to stay away. Paraguay, under the dictator Francia, was maintaining a policy of isolation from all the world at that time, so refused all relations with the meeting. As the Chilean historian B. Vicuña Mackenna says: "As far as Chile and La Plata were concerned, they refused to send delegates to the assembly because of a petty suspicion con;cerning the designs for universal power attributed to Bolivar."

The Congress was to consider, according to a letter from the Colombian Government to its representative in Buenos Aires, the following matters:

I. "To renew the treaty of union, alliance, and perpetual confederacy against Spain or any other power which might attempt to dominate over us.

2. "To issue, in the name of their constituents, a suitable manifesto upon the justice of their cause, exposing the sinister views of Spain and declaring our system of politics with respect to the other powers of Christianity. 
3. "To consider the condition of the islands of Porto Rico and Cuba; the expediency of a combined force to free them from the Spanish yoke; and the proportion of troops which each state should contribute for that purpose ; and to determine whether the islands shall be united to either of the confederated states or be left at liberty to choose their own government.

4. "To conclude or renew a treaty of commerce between the new states as allies and confederates.

5. "To conclude a consular convention between all, which should clearly and distinctly lay down the functions and prerogatives of their respective consuls.

6. "To take into consideration the means of giving effect to the declarations of the President of the United States of America, in his message to the Congress of last year, with a view to frustrating any future idea of colonization on this continent by the powers of Europe, and to resist any principle of interference in our internal affairs.

7. "To establish in concert those principles of the rights of nations, which are of a controversial nature, and especially those which relate to two nations, one of which is engaged in war, whilst the other is neutral.

8. "Lastly, to declare on what footing the political and commercial relations of those parts of our hemisphere, which, like the island of Santo Domingo or Haiti, are separated from their ancient government, and have not yet been recognized by any European or American power, should be placed.'

Bolivar's first invitation did not include the United States, which was afterward invited by representatives of the Colombian and Mexican Governments. ${ }^{2}$ President Santander

\footnotetext{
2 This has led some writers to assert that Bolivar was an enemy to the United States. But this is not borne out by the facts, as is shown in the excellent study of Prof. W. R. Shepherd, in his pamphlet, "Bolivar and the United States."

While Bolivar did not believe that Colombia and other Latin American coun. tries were ready to follow the United States in her federal constitution, yet he spoke many times of the wonderful country toward the North. In his famous Jamaica letter he wrote:

"As long as our compatriots do not acquire the political talent and virtues that distinguish our brothers of the North, systems entirely popular far from being advantageous to us, I fear greatly, may come to be our ruin. Unhappily these qualities in the requisite degrees seem very distant from us. On the contrary we are dominated by the vices contracted under the rule of a nation like the Spanish, which has excelled only in pride, ambition, prejudice and avarice." (Blanco Fombona. "Bolivar y la Liberación de Sur América," Vol. I, page 383.)

Concerning Bolivar's evident desire that the United States participate in the
} 
of Colombia, referring to this matter, said: "In regard to the United States I: have believed it important to invite them to the Assembly at Panama, being convinced that our allies would see with satisfaction the taking part in the deliberations concerning our common interests such sincere and illustrious friends."

President John Quincy Adams, although warmly espousing the cause of the young southern nations, yet hesitated at first to accept the invitation because the United States was neutral in the conflict with Spain, with whom we had been treating for the purchase of Florida. However, on December 26,1825 , the President sent to the Senate the appointment as plenipotentiaries of the United States of two eminent men, Richard C. Anderson of Kentucky, and John Sergeant of Pennsylvania. There was such determined opposition by the Senate that it looked as though the proposal would be defeated. The discussions concerning the invitation to join this first League of Nations make strangely interesting reading in view of the Senate's debates concerning the Covenant of the Versailles League. Happily it only required five months in these early days to reach an affirmative vote and confirm the commissioner's nomination. Their instructions, dated May 8, I 826 , were drawn by Henry Clay and signed by him as Secretary of State.

\section{INSTRUCTIONS OF UNITED STATES DELEGATES}

Covering a wide range, they disclosed the broad and farreaching views to which, in cooperation with President Adams, he sought to give effect. First the instructions declared that the President could not have declined the invitation to the Congress without subjecting the United States to the reproach of insensibility to the deepest concerns of the

Panama Congress, O'Leary, his secretary, writes on page 36 of "Brief Data for the Diplomatic History of Colombia," as follows:

"Colombia ordered Salazar, its Minister in Washington, to sound the intentions of that government regarding the great assembly and in case it were favorably disposed formally to invite it to send plenipotentiaries to Panama, who, in union with those from Colombia and allies, should concert efficacious means of resisting all foreign colonization on the American Continent and to the application of legitimate principles to the American states in general." ("Bolivar y la Liberación de Sur América," Vol. II, p. 621.) 
American hemisphere. Moreover, the assembling of a Congress would "form a new epoch in human affairs." Not only would the fact itself challenge the attention of the civilized world, but it was confidently hoped that the Congress would "entitle itself to the affection and lasting gratitude of all America, by the wisdom and liberality of its principles" and by the establishment of a new guarantee for the great interests which would engage its deliberations. At the same time the fact was emphasized that the Congress was to be regarded as a diplomatic body, without powers of ordinary legislation. It was not to be an amphictyonic council, invested with power finally to decide controversies between the American states or to regulate in any respect their conduct, but was expected to afford opportunities for free and friendly conference and to facilitate the conclusion of treaties.

After these preliminary explanations, the instructions proceeded to point out that it was not the intention of the United States to change its pacific and neutral policy. While, therefore, the Congress probably would consider the future prosecution of the war with Spain by the existing belligerents, the delegates of the United States were not to enter into a discussion of that subject, but were to confine themselves strictly to subjects in which all the American nations, whether belligerent or neutral, might have an interest. One of these was the maintenance of peace, which was declared to be the greatest want of America.

In regard to European wars, confidence was expressed that the policy of all America would be the same, that of peace and neutrality, which the United States had constantly labored to preserve. On this supposition, the greatest importance was, said the instructions, attached to questions of maritime neutrality. The delegates were to bring forward the proposition to abolish war against private property and non-combatants upon the ocean, as formerly proposed by Dr. Franklin; but as this might not be readily adopted, they were authorized to propose that free ships should make free goods and that enemy ships should make enemy goods, both rules being considered to operate in favor of neutrality. The 
delegates were also to seek a definition of blockade, and were, besides, to deal with the subject of contraband.

In regard to commercial intercourse, the instructions incorporated the most liberal views. The delegates of the United States were not to seek exclusive privileges even as against the European powers. They were to observe the most-favored-nation principle, so that any favors in commerce or in navigation granted by an American nation to any foreign power should extend to every other American nation; and were to oppose the imposition of discriminating duties on importations or exportations on account of the flag.

As for the Monroe Doctrine, the delegates of the United States, without committing the parties to the support of any particular boundaries or to a joint resistance in any future case, were desired to propose a joint declaration that each American state, acting for and binding only itself, would not allow a new European colony to be established within its territories.

Concerning Cuba and Haiti, which the Congress might consider, the stating of a satisfactory position was much more difficult. As to Haiti (which, as a "negro republic," was closely associated with the slavery question ) the opinion was expressed that it was not necessary for all America to agree upon it. Respecting Cuba, the United States would like to see it free itself, but could not see its freedom guaranteed by other powers, European or American, neither could it look with favor on its being conquered and ruled by Colombia and Mexico, which was reported to be the plan of those countries.

The instructions further suggested that a joint declaration be made in favor of freedom of religious worship; that concerning government, the United States preferred their own confederacy to all other forms, but as they allowed no foreign interference in their own government, they were "equally scrupulous in refraining from all interference in the original structure or subsequent interior movement of the governments of other independent nations."

Anderson, who was then Minister to Colombia, started to Panama, but died on the way at Puerto Bello. Sergeant saw 
the uselessness of making the attempt but later went to Tacubaya where the second session was scheduled to take place.

Delegates from Colombia and Peru went early to the Isthmus and tegan their parleys almost a year before the formal opening of the Congress, which took place on June $22,1826$.

\section{THE CONGRESS IN ACTION}

In an inaugural address the Peruvian deputy Vidaurre spoke of two things that threatened peace in Americaimperialism of certain states (not then referring to the United States) and the anarchy within other states. "Let us form one family, forgetting the names which distinguish each country and let us be brothers all," said the distinguished Peruvian. Panama proved to be anything but a propitious locality for the developing of such a brotherhood. Its unhealthfulness, connected with the small attendance, caused an early adjournment.

The principles adopted at this Congress were:

I. Countries to aid one another with military and naval forces if attacked by foreign nations;

2. To settle all disputes by friendly arbitration (thus it is seen that arbitration originated in Latin America);

3. Extend the rights of citizenship in each country to citizens of other American countries;

4. Renounce the traffic in slaves; and state.

5. Guarantee mutually the integrity of each American

It was decided that an Assembly should be organized to meet every two years to:

I. Negotiate treaties to promote satisfactory relations between the American countries;

2. Contribute to maintenance of peace among the American nations;

3. Forward the habit of conciliation among allied and foreign powers;

4. Offer its good offices to terminate wars. 


\section{EARLY EFFORTS TOWARD PAN AMERICANISM 111}

\section{FAILURE OF ADJOURNED SESSION}

The Congress adjourned on July I $5^{\text {th }}$ to meet at Tacubaya, a suburb of the City of Mexico. One of the delegates from each country returned home to report to his government and secure the ratification of the agreements of the Congress, and the other proceeded to Tacubaya to await the opening of the second session. Only Colombia approved the proposed agreement. Several representatives remained in Mexico for some time awaiting such approval, but not even the Mexican government itself would face the matter, since a revolution started about then that took all the officials' time. So the representatives of the United States and other countries finally left for home, with nothing accomplished.

As a Peruvian writer says: "These were platonic votes in an hour of grave dissension, noble ideals confronted by premature wars." Even Bolivar himself seemed to have lost confidence in the movement, before the meeting's adjournment. His power had already begun to wane, and about this time he left Peru, discredited, and returned to Colombia, with the hope of staying the movement against him there. Of the Congress he said: "The Panama Congress, which would have been admirable if it had been more efficacious, reminds me of that Greek madman, who, from the summit of a rock, pretended to direct the movement of vessels on the high seas." The various ships of state went to pieces rapidly and Bolivar, everywhere discredited, died of a broken heart.

The seed planted by him were, however, destined to grow, slowly it is true, through the years, with both North and Latin Americans working away at the problems that his far-seeing vision had realized must be solved before the American republics can attain their rightful place in world leadership. While much is yet to be accomplished, at least the following of Bolivar's Panama program has been worked out: arbitration, abolition of slavery, settlement of most boundary disputes, standing together against European intrusion, building of the Panama Canal, the uniting of all American nations in the Pan American Union. 


\section{SUCCESSORS TO BOLÍVAR}

Soon after the Panama Congress Bolivar died, but it is most interesting to see how other Latin American leaders went on amid all kinds of discouragements, patiently working at the problem of unity.

The government of Mexico in March, I83 I, invited all the republics of America to attend a conference to be held, at the option of a majority, either in Tacubaya, Panama or Lima. In the absence of tangible results, Mexico induced Venezuela to second it in the task of :

"promoting the union and close alliance of the new states for defence against foreign invasion; for the acceptance of friendly mediation of the neutral states; for the settlement of all disagreements and disputes of whatever nature that might happen to arise between the sister republics; and for the framing and promulgation of a code of public law regulating their mutual relations."

The Mexican statesman, Juan de Dios Cañedo, as Minister to Peru and other South American states from I83I to I839, and later as Minister of Foreign Relations, worked assiduously at the task of union during this period. But, as Nuñez Ortega points out, the work of Señor Cañedo seemed to be lost because of the rivalries between Bolivia, Peru, Chile and Buenos Aires, and because of continued internal disturbances, the anarchy and extreme poverty of these states during this period.

But the idea, like all true visions, would not down. Colombia and Mexico having failed as leaders to bring about desired unity, Peru now became the noble knight who was to do valiant service for many years for the ideal.

The occasion for the calling of the next congress was the movement of Spain, encouraged by the Ecuadorian Juan José Flores, to reconquer her colonies on the Pacific.

\section{THE "AMERICAN CONGRESS"}

This was called the "American Congress" and met at Lima from Dec. I, I847, to March Io, I848, on the initiative 
of the republics of Bolivia, Chile, Ecuador, Nueva Granada and Peru. The fundamental ideas of this second assembly did not differ from those of the first : the territorial integrity and political independence of the federated states; defensive alliance against aggression of foreign powers; unification of the rights of Americans; confirmation of agreements from 1810-1824 that fixed the frontiers of the new republics; solidarity in the repression of interior anarchy; defense of a democratic régime; abolition of slavery, and an ideal fraternity.

Bolivia, Chile, Ecuador, Nueva Granada and Peru sent delegates to the conference. These delegates recognized in the treaty signed Feb. 8, I 848, that "the American Republics joined together by the principles of origin, language, religion and customs; by their geographical position; by the common cause which they had defended; by the analogy of their institutions, and, above all, by their common necessities and reciprocal interests cannot consider themselves except as parts of one and the same nation."

The plenipotentiaries meeting in Lima, as those that met in Panama, resolved that a Congress formed by the ministers of the contracting states should meet every three years, more or less, in extraordinary session. The zealous patriotism of these nations, however, thought it saw a danger to their autonomy in the permanency of this proposed congress. So they called it an Assembly, in order not to confound it with the national congress. Its attributes, very much limited, consisted mainly in the interpretation of treaties that the interested parties might conclude among themselves and in the right of benevolent intervention in future conflicts in order to propose conciliatory measures. Thus it was that a moral power, a species of advisory board, "inefficient and solemn," was proposed in this period of American evolution.

This conference was distinguished, however, by a tentative practical agreement providing that: "the natural products and manufactured articles of any of the confederated republics that should be introduced in other republics in national bottoms would only be charged one-third part of the importation duties that were charged to outside nations." 
Thus it was that the political discussions were converted into a practical resolution. A half century later Secretary of State Blaine adopted the same plan, as a necessary antecedent to Pan Americanism. While these States were sitting in council to devise means of uniting America to protect themselves from foreign invasion, the United States was at war with Mexico. So of course neither she nor Mexico had any part in the Congress.

Unfortunately the decisions of this "American Congress". met with little more enthusiasm in the various national governments than had those of the Panama gathering.

\section{BEGINNING OF SUSPICION OF THE UNITED STATES}

The expeditions of the North American filibuster, Walker, against Central America led to the next movement for unity among the Spanish-American countries, which had now become fearful of the United States as well as of Europe. Peru, again leading, sent arms and money to her brothers in Central America and initiated a movement which resulted in the so-called "Continental Treaty" or Triple Alliance (Pacto Tripartito) which was signed September 15, 1856, in Santiago by the representatives of Peru, Ecuador and Chile. This treaty was more careful than previous ones to guard the rights of each country, to conserve its autonomy and the integrity of its territory. The securing of the signatures of the other Hispanic American countries was left to Peru. In presenting the treaty to Argentina, in 1862 , the Peruvian minister expressed the ideas behind it, as follows:

"The government of Peru, witnessing what has recently taken place in Mexico and Santo Domingo, which signifies a general danger to independent America, believes that one of the first steps that ought to be taken to ward off this danger is the unification, in the republics of this continent, of certain principles which should be made a part of their international law, and the development of friendly relations and good understanding among these peoples and governments in order to eliminate in the future all kinds of war. Because such hostile acts have even overtaken Anglo-Saxon 
America, a just alarm intimates the arrival of an hour when we should proceed to an understanding concerning the bases of a general American peace and union, in order that the nations of this continent may form an alliance, if the same attacks should be made on their liberty that were made against Mexico."

Guatemala, in agreeing to sign the pact, said: "There has been an endeavor to impress all these states with the idea that the happiness of the whole continent, including the two Americas, depends on subjection to that republic (the United States of America) sustaining that the 'Manifest Destiny' of that republic is to make uniform her principles and interests with those of every other American nation."

\section{DIFFERENCES BETWEEN VARIOUS COUNTRIES}

Colombia, in response to Peru's invitation to sign the Triple Alliance agreement, accepted the invitation but pointed out to the Peruvian ministry that the Colombian government had already planned to invite the governments of both Americas to send representatives to an International Congress of Republics, to be held in Panama as soon as it seemed necessary to meet the evidently hostile intentions of Europe. Colombia did shortly after issue a statement to the American governments which proposed an "American Decalogue," consisting of ten articles looking toward united action of all America, to be discussed at the conference provided for in Article XX of the Triple Alliance agreement. In response to this note the government of Costa Rica proposed "a new treaty by which the United States would contract the solemn duty of respecting and cause to be respected the independence, sovereignty and territorial integrity of her sister republics of this continent."

The governments of Mexico, Nicaragua, Bolivia, Honduras, Colombia and Costa Rica either signed the Triple Alliance agreement or endorsed its ideas. Argentina challenged the whole assumption of the treaty, saying through Minister Elisandre: "Independent America is a political entity that does not exist, nor is it possible to constitute it by diplomatic fulminations. America contains independent na- 
tions with their own institutions and means of government and cannot form one political entity."

Argentina had now found out the advantages of her geographical situation. She was to receive capital and immigration from Europe. Indeed she already felt in her ports the rumbling of a tumultuous immigration and thought that there existed for the Spanish-American republics more ties, more interests, more harmony with Europe than with one another. She did not fear the aggressions of monarchical governments. Indeed such men as Alberdi argued that it was from Europe that Argentina might expect the most help. In international relations then she proposed to do away with antagonisms with the governments and the peoples of Europe and to bring together, on the contrary, all the forces and elements that were able to help in developing her national resources; to foment the reconstruction of the nationalities of America that imprudently had divided and subdivided; not to place herself in opposition to other governments because they do not accept her form of government; to look for harmony with the United States instead of excluding it and keeping it off at a distance; to resist every aggression of American states to conquer them and to annul the form of republican government; to abandon the idea of an American Congress as impossible and to substitute the signing of treaties of alliance to guarantee the defense and common security of all America.

"Facing this Colombian position of platonic congresses," says García Calderón, "we find the Argentinian belief in the utility of alliances. Neither in 1856 nor today is the American continent unified. Deserts, undiscovered stretches of territory, geographical differences separate these peoples. To force a political unity on diverse nations without creating interests, without joining up territories, without reconstructing sterile national division, was a utopian scheme."

The skepticism of the Argentine politicians threatened to destroy the noble Americanism of the liberators, thought the Peruvian statesmen, one of whom observed pessimistically: "This is the first time since our great Revolution that the voice of a government has arisen opposing what for the 
Americans has come to be a principle and dogma founded in the glories of the past, in the hope of the future, and the fraternity of all times. The Argentine Republic was the first soldier of the independence of America. If today, when danger is near, the means of combating it is sought, she prefers to desert, denying the principal basis of her grandeur, not recognizing in herself anything but a mixture of nationalities with isolated and diverse interests, she could not forget without hurting her deserved renown, that she was also the first in recognizing American unity through the acts of her greatest citizens and the sacrifice of her treasures and blood."

Whatever objections Argentina, more practical than her tropical neighbors, may have had to this merry round of meetings, that worked for a close federation of American nations, she was always a leader in advocating arbitrationcompulsory arbitration at that. This position was clearly stated in a notable paper, written by Minister Irygoyen, in answer to Colombia's invitation to the second Panama Congress. Señor Irygoyen said:

"Arbitration is certainly a noble aspiration of the present day and the Argentine government can point with pride to its endorsement, from an early date, of that measure which wisely reconciles the requirements of justice with the generous sentiment of mankind. It had occasion to stipulate for it with the most excellent government of Chile in 1856 , to settle boundary disputes then existing and those which might thereafter arise. It declared in 1874 , in official documents published to the world, that it was 'resolved, with or without treaties, to settle all international controversies by arbitration'; and, faithful to those declarations, it submitted in I 876 its differences with Paraguay to arbitration, after a long war pursued for reasons of honor and of security in which its arms and those of its allies completely repelled the advances of that nation."

Along with Argentina, Chile, the other most southern country, blessed with stable government and no doubt in- 
fluenced with imperialistic ambitions, had in different ways shown inclinations to "throw the monkey wrench into the machinery" of a smooth-working American unity toward which the countries of the more tropical lands were continuously working. Following her war with Peru and Bolivia, when she added three rich northern provinces to her territory, she was naturally more careful than ever about entering into unions and blanket agreements concerning arbitration.

But Peru continued her ardent support of the American Ideal and in I864 again invited the American nations to a new Congress in order to give the continent "a peculiar form." The special occasion for the Congress was of course the intervention of Spain in Santo Domingo and the intervention of France in Mexico. Peru also showed practically her sympathy for Mexico by sending a large amount of war material and money to Mexico, with a special salutation in the form of a gold medal to the intrepid little Indian, Juárez. The principles submitted to the assembly were not new : To formulate a new family of nations; to maintain the integrity of their territory; to oppose foreign domination; to provide for compulsory arbitration and to discuss certain practical questions-commercial and postal conventions, a common currency and an exchange of products.

\section{SECOND "AMERICAN CONGRESS"}

This Second American Congress met in Lima, from November 14, I864, to March I3, 1865. In its sessions, as also in those of the previous one, fears were expressed of the way the United States was working out its "Manifest Destiny" program. One of the delegates said: "Liberty is not unknown either in monarchies or in republics; it is enjoyed in monarchical England as also in the most advanced of the republics. The friendship of Europe should be sought. The natural preponderance of a powerful neighbor disturbed us all. The political policies of North America continue to be threatening and the enthusiasm for her statesmen during I 826 is now lost."

The Congress was attended by many eminent men: $\mathrm{Paz}$ 
Soldán of Peru; Manuel Montt, founder of a political party and president of Chile; Antonio Leocadio Guzmán, liberal politician of great influence in Venezuela; and finally, Sarmiento, leader of democracy in Argentina. The danger from Spain gave a tragic prestige to the deliberations of this assembly. Unanimously it rejected the claims of Spain. As in the times of the great Revolution, the international cords that bound them together were strengthened and an alliance between Colombia, Peru, Ecuador, Venezuela, Salvador, Bolivia and Chile covenanting to defend their own political life and their national integrity, to agree to compulsory arbitration, reciprocal commercial, navigation and postal exchange, was the final decision of this powerful gathering of peoples. But the governments seem to have paid no more heed to this congress than to the one at Panama and the first one at Lima, so that the proposals were not formally accepted by. a single country.

\section{VARIOUS OTHER EFFORTS AT UNITY}

Peru and Chile entered into an offensive and defensive treaty in 1865 , because of the threat of Spain to reconquer her Pacific colonies. Ecuador and Bolivia later joined in the pact, which found a practical application when Spain did actually attempt to reconquer these countries, and they were called to a common defense of their sovereignty.

On May 18, 1867, while still at war with Spain, a treaty was signed at Lima between Chile, Ecuador and Bolivia relating to questions of international law. The unity of Central America was the object of many efforts during this period, as it has continued to be up to the present. In 1876 Guatemala convoked a Central-American congress for this purpose, but owing to an outbreak of war between that country and Salvador the invitations were withdrawn and the congress was held on the 20th of January, 1887 . As a result of that conference others were celebrated in Costa Rica in 1888 , and in Salvador in I889, when the idea of organizing the republics of Central America was further discussed.

As the eminent jurist, Alejandro Álvarez, says : 
"The states of Latin America, in spite of the fact that they had abandoned by this time the idea of a confederation, continued to consider themselves as a family of nations, in which friendly relationships, close commercial intercourse and a consensus of agreement on external policy should exist."

In short, Señor Álvarez declares that the idea of solidarity did not disappear, but assumed a more practical aspect in conformity with the international life of these countries. This interpretation is confirmed by the fact that there assembled in Lima Dec. 9, I877, by the invitation of the Peruvian government, an American congress of jurists to unify the principles of private international law. There were present representatives from Argentina, Bolivia, Chile, Ecuador, Peru, Colombia, Guatemala, Honduras and Venezuela. This congress agreed upon two conventions, one relating to private international law and the other to extradition. The meeting had a sad ending, when its sessions were interrupted by Chile's forces capturing and sacking the city of Lima.

From I866 to 1872 , which covered the period of the war between Spain and the republics of Peru, Chile, Bolivia and Ecuador, the remarkable and successful efforts at mediation of the United States between Spain and these republics form one of the most noteworthy events in the history of Pan Americanism. The final and definite conference, called for the purpose indicated, took place at Washington on October 29, I870, under the presidency of Mr. Fish, then Secretary of State: On April I I, I87 I, an armistice was signed, which "armistice or truce" was to "continue indefinitely." Under the terms of this armistice hostilities might not be resumed by either of the belligerents "save three years after having expressly and explicitly notified the other."

In I880 Colombia invited the republics of America to a congress to meet at Panama in I88I for the purpose of securing the adhesion of these republics to the principle of arbitration incorporated in a convention which Colombia had celebrated with Chile. All the countries invited, except Mexico and Argentina, accepted the invitation. Owing, however, to the fact hat Chile interpreted the objects of the 
conference as constituting a desire to intervene in that country's external policy, a campaign of opposition was begun, with the result that when the congress met, there were only present the representatives of three Central-American republics.

In 1883 , on the centenary of the birth of Bolivar, in the city of Caracas, the representatives of Argentina, Bolivia, Colombia, Peru, Salvador, Mexico and Venezuela signed a convention recommending arbitration.

In $1887-1888$ there were convened respectively at Rio de Janeiro and Lima two sanitary congresses, Argentina, Brazil and Uruguay being represented at the first of these, and Bolivia, Chile, Ecuador and Peru at the second.

In I888-I 889 a congress on private international law was held at Montevideo. The invitations were issued jointly by Argentina and Uruguay, and, besides those two countries there were representatives present from Bolivia, Brazil, Chile, Paraguay and Peru.

Equally important with these various conferences in showing the earnest desire of America for unity is the long list of authors and statesmen who have worked incessantly for this great idea. Vicuna Mackenna in his "Estudios Históricos" gives a list of thirty well-known publicists, along with their contributions to the subject. These men differed very widely in their plans and in their inclusion or exclusion of the United States, Brazil and Europe in connection with the federation, but they all firmly believed in the necessity of American solidarity.

Among the best of these studies was the thesis presented by the celebrated Argentine statesman, Juan Bautista Alberdi, to the University of Santiago, Chile, as a requirement for the degree of Doctor of Laws. He outlined the following subjects as those which ought to be discussed by a Pan American Congress:

I. First, adjustment of boundaries between the American states;

2. The regulation of maritime and river traffic;

3. Protection of commerce;

4. Unifying customs duties; 
5. Uniformity in currency, weights and measures;

6. Uniformity in banking arrangements ; tinent;

7. Foundation of a bank for public credit for the con-

8. Validation of incorporation;

9. Validation of scientific and professional diplomas;

Io. Copyrights;

I I. Construction of international railroads;

I2. Postal unions;

I3. Extradition of criminals;

I4. Limitation of armies;

I 5. Establishment of an international court of peace;

I6. Determination of American international law;

I7. Prevention and control of war;

I8. Development of colonization;

19. Construction of a Trans-Andean railroad.

As Mackenna well says, as he refers to the lack of practical accomplishments favorable to unity: "One most consoling conclusion is clear, in this solemn hour, when this subject is agitated in parliament and in the press, and has become a never-ending study for youth - this movement for unity has been maintained without faltering from the first years of our independence until the present day (I862) when it has become a universal American agitation."

Ernesto Quesada of Argentina sums up these conferences as follows: "These conventions remain as a monument to the honor of Bolivar and Latin America as heralds of the lofty aspirations which they embody; and the republics of the New Continent, true to them, have generally followed the principle of arbitration for the settlement of international disputes."

Dr. Francisco Castañeda of Salvador, who has just made (I920) a most interesting study of these efforts at American unity, says :

"Such has been the process by means of which in evolutionary growth across the years and under the influence of diverse elements and circumstances, American friendship has developed. Born because of natural desires, with a common perspective of fear, it has received a healthful expansion in 
searching for the realization of the ideals of modern international law. That which in its origin was the aspiration of a race at present is the bond of union and obligatory program of all the countries of the continent without reference to the various ethnic factors nor to the distinct sociological conditions.

"Pan Americanism has enlarged the political horizon and amplified its forms so that it now embraces every subject that refers to prosperity and the development of the peoples of the western hemisphere. Complying with that is the most far-reaching interpretation of Mr. James Blaine's declaration at the inauguration of the first congress, so beautifully interpreted and broadened by Secretary of State Elihu Root, at the Third Pan American Conference in Rio de Janeiro, and a few days afterwards in Buenos Aires, when he said: 'We do not make alliances. This is our traditional attitude which we received from George Washington and which his successors have respected always. But there are alliances which, although they are not derived from written documents and treaties, are very formal ones. We have thus an alliance with our sister nations upon this continent, one of sentiment, of fraternity, of the common prosecution of the ideals of liberty and justice, one which seeks a common good for all.'

"Here is the synthesis of the new policy. Here is the new and important phase of the subject which should be considered. Partial alliances have no reason for existing. Those that are necessary, those which duty imposes upon us and which must be fought for at all times, are those which unite in a strong embrace and by a common law all the peoples of the continent. This is the elevated point of view taken by thinkers and statesmen, and on the success of which depends the development of continental policies and universal good will."

Sources of Further Information on Early Efforts Touard Pan Americanism

Akanda, Ricardo: Congresos y Conferencias Internacionales en que ha tomado parte el Peru. 
Calderón, F. García: La Creación de un Continente.

CANDLER: Inter-American Acquaintances.

Castaneda, Francisco: Nuevos Estudios.

Lockey, Jos.: Pan Americanism, Its Beginnings.

Maurtura, Anibal: La Idea Pan Americana y la Cuestión del Arbitraje.

Moore, JoHn B.: American Diplomacy, Chapter on Pan Ámericanism.

O'Leary, Daniel F.: El Congreso Internacional de Panamá en I826.

O'Leary, Daniel F.: Bolívar.

Quesada, ERnesto: La Evolución del Panamericanismo.

Robertson, Wm. Spence: Rise of Spanish American Republics, Chap. VII.

Urutia, Francisco José: Los Estados Unidos de America y las Republicas, Hispano Americanas, de I8Io a 1830.

Files of "Inter-America" contain valuable material on this subject. 


\section{Chapter IV}

\section{EARLY EFFORTS OF THE UNITED STATES TOWARD AMERICAN FRIENDSHIP}

We have seen in former chapters that the leaders of Hispanic America during their struggle for independence and the development of their national life thought much of continental solidarity, and regarded so highly the United States that they modeled their governments after that of the republic of the north. We now come to look at the other side of the shield and inquire concerning the attitude of the United States towards Hispanic America.

It is of greatest importance to clear up this matter because many Latin American leaders, especially during the last twenty-five years when the prejudice toward the United States has been most largely developed, have claimed that the United States, if not hostile to Hispanic American independence, at least did nothing to aid it. Such writers as President Saenz Pena of Argentina, Pardo of Brazil and Fombona of Venezuela have made much of this argument in their general program of opposition to this country.

Some twenty years ago the Mexican Ambassador, Matias Romero, wrote an article in The North American Review that attracted wide attention. In it he took the ground that the United States did not render either material or moral assistance to the Spanish colonies in their struggle for independence. Senator Mooney, of Mississippi, answered the paper, expressing the feelings of most North Americans when he said that Romero's contention left a disagreeable impression on the minds of North Americans, who gloried in the fact that their government had always sympathized with peoples struggling for liberty, and especially so in refard to the peoples on this continent. 


\section{PERIOD OF BENEVOLENT NEUTRALITY}

While it must be admitted that the young and comparatively weak government of the United States found it wiser to declare officially her neutrality in the war between Spain and her colonies, this was not due to any lack of sympathy with the colonies but to the policy adopted on the advice of Washington concerning "entangling alliances," which was from the first interpreted to include non-intervention in other nations' affairs and non-participation in arrangements between other governments. The case of Great Britain, which some of the Latin American historians praise for her help as much as they condemn the United States for her lack of it, was entirely different. She was playing the game of world politics and she had her own purposes to fulfill in encouraging the patriotic cause in the Spanish colonies, as is well revealed by the boast of Canning, idle as it was, when he said that he had brought a new world into existence to redress the balance of the old. The United States was working from just exactly the opposite motive-to keep America out of the eternal question of the balance of power in Europe and have it develop along its own distinct democratic lines. Time has shown that the young and weak government of the United States rendered its best service to its southern neighbors by saving its strength to protect all America from Europe, rather than by rendering some little ineffectual aid to the Spanish colonies, who, it was evident, would be able to gain their freedom unassisted.

The neutrality declared was indeed a benevolent neutrality, similar to the one declared in the first part of the recent World War, when the liberal forces could count on much help from the United States. The various steps openly taken and the frank avowals of sympathy by the United States Government for the southern colonies, confirm the deep interest felt in their welfare and the hopes for success in their fight for independence. This sympathy was so clear to Spain that she made it the reason for delaying several years the signing of the treaty which conveyed Florida to the United States. Indeed President Monroe at one time confessed that, from the first, the struggle was regarded "not 
in the light of an ordinary insurrection or rebellion, but as a civil war between parties nearly equal, having as to neutral powers, equal rights."

One of the first approaches toward the great subject of American solidarity that history reveals to us was that of a Brazilian student named Maia, to Thomas Jefferson in 1787 , when both were in Paris. Maia was one of a company of conspirators who were planning the independence of Brazil. In appealing to Jefferson to help Brazil, this young student struck the keynote of Pan Americanism, which in spite of many vicissitudes, was to ring through all time. The United States should be their natural friend, said Maia, "because nature in making us inhabitants of the same continent has in some way united us in the bonds of a common patriotism." Even before this a Mexican had spoken to Jefferson about a possible revolution in Mexico, which drew from our representative the following, written to his friend Jay: "However distant we may be, both in condition and disposition, from taking an active part in any commotion in that country, nature has placed it too near to us to make its movements altogether indifferent to our interests." This beginning of interest in Hispanic American affairs grew steadily with Jefferson until it became one of the outstanding interests of his life.

The friendship of the people of the United States was shown by the help that Hamilton gave Miranda, the forerunner of South American independence, when he came to the United States in 1805 to fit out an expedition to free the South American colonies. He received at least enough encouragement from President Jefferson, who had already shown his strong faith in the great future of the American continent, to write the President, "If the happy prediction which you pronounced upon the future destinies of our dear Colombia is to be accomplished in our day, may Providence grant that it may be under your auspices." Two years later Jefferson appointed a special agent, Gen. James Wilkinson, to visit at least Mexico and Cuba to thus demonstrate the interest of the United States in its southern neighbors.

Writing about this same time to Governor Claiborne of . ouisiana Jefferson said, "The truth is that the patriots of 
Spain have no warmer friends than the administration of the United States. *** We consider their interests and ours as the same, and the object of both must be to exclude all European influence from this hemisphere."

It was the year I810, the most memorable in the annals of Hispanic America, that brought a definite open movement by the Government of the United States to form closer relations with the Spanish colonies. In that year revolts from Spain were formally declared in Venezuela, Argentina and Mexico. When news of these reached Washington President Madison appointed Joel R. Poinsett, a brilliant politician of South Carolina who was destined to play a prominent part in interAmerican relations for the next twenty years, to visit Buenos Aires and probably Chile and Peru on a friendly mission. Because this appointment marks a new departure in the foreign policy of the United States, it seems well to give here his letter of instructions, dated June 28 , I8Io, and written by Secretary of State James Monroe as follows:

"As a crisis is approaching which must produce great changes in the situation of Spanish America, and may dissolve altogether its colonial relations to Europe, and as the geographical position of the United States, and other obvious considerations, give them an intimate interest in whatever may affect the destiny of that part of the American Continent, it is our duty to turn our attention to this important subject, and to take such steps, not incompatible with the neutral character and honest policy of the United States, as the occasion renders proper. With this in view, you have been selected to proceed, without delay, to Buenos Aires. You will make it your object, whenever it may be proper, to diffuse the impression that the United States cherish the sincerest good will toward the people of Spanish America as neighbors, as belonging to the same portion of the globe and as having a mutual interest in cultivating friendly intercourse; that this disposition will exist whatever may be their internal system or European relation, with respect to which no interference of any sort is pretended; and that, in the event of a political separation from the parent country, and of the establishment of an independent system of national 
government, it will coincide with the sentiments and policy of the United States to promote the most friendly relations, and the most liberal intercourse, between the inhabitants of this hemisphere, as having all a common interest, and as lying under a common obligation to maintain that system of peace, justice and good will, which is the only source or happiness for nations.

"Whilst you inculcate these as the principles and dispositions of the United States, it will be no less proper to ascertain those on the other side, not only toward the United States, but in reference to the great nations of Europe, and to the commercial and other connections with them, respectively ; and, generally, to inquire into the state, the characteristics, and the proportions, as to numbers, intelligence, and wealth, of the several parties, the amount of population, the extent and organization of the military force, and the pecuniary resources of the country.

"The real as well as ostensible object of your mission is to explain the mutual advantages of commerce with the United States, to promote liberal and stable regulations, and to transmit reasonable information on the subject. In order that you may render the more service in this respect, and that you may, at the same time, enjoy the greater protection and respectability, you will be furnished with a credential letter, such as is held by sundry agents of the United States in the West Indies, and as was lately held by one at Havana, and under the sanction of which you will give the requisite attention to commercial objects."

That the appointment of Poinsett was appreciated and remembered is seen in the following which appeared in $L a$ Prensa, of Buenos Aires, on the occasion of the visit of the United States battleships to that city in the critical days of I9I7:

"Economic relations, liberal and ample, were initiated in I 810 between the United States and the River Plate. Since then the Spanish colonies in their struggle for independence have not lacked the help and moral support of the Union, although at certain times the necessities of European poli- 
tics compelled the withholding of practical help. The persevering work of eminent men always advanced the cause and culminated in the recognition of our independence, followed by the proclamation of the Monroe Doctrine. The attitude recently proclaimed by President Wilson in his immortal message in regard to Pan Americanism is the same that moved the Union to send an agent to Buenos Aires in I8Io to cut across the plans of the Holy Alliance and to prevent the invasion and conquest of America in 1823 . Behold the hand of Argentina now extended in this crisis, marking her frank adhesion to the attitude of the great Republic of the North."

Poinsett also went to Chile, where he was received with the greatest enthusiasm, President Carrera welcoming him in a speech which was filled with admiration of the United States. Poinsett, in reply, said that the Americans of the North had the deepest interest in the events taking place in these countries and ardently desired the prosperity and happiness of their southern brethren, and that he would inform his government about the desire of his Excellency for friendly relations, considering it a great honor to be the first to establish relationships between these two nations, which should be united as friends and allies.

Robert K. Lowry was sent about the same time to Venezuela, where he counseled the leaders of the incipient democracy in their first attempts in republican government. $\mathrm{He}$ remained in Venezuela until independence was secured, engaging in business afterward until his death.

Thomas Sumter, a third agent, appointed by Madison at this time, was received at Petropolis by the Prince Regent, John VI, as United States Minister to Brazil. This marked the beginning of a century of close relations with Brazil. The Brazilian representative to Washington, José M. de Camara, was received May I3, I8Io. Brazil was the first American power to endorse the Monroe Doctrine and on the other hand the United States was the first foreign power to recognize the Empire of Brazil, May 26, I824, a year and a half after its independence was declared. 
As the well-known Brazilian internationalist, Pereira Pinto, said in 1865 : "It was the North American Republic that first recognized the independence of Brazil. Great Britain was impelled to favor our freedom because of her liberal system of government and her tenacious aspirations to abolish slavery, but hesitated to do so because of her historic and faithful ally, Portugal. The United States consequently with that clear attitude which they had adopted toward all the American peoples that had separated themselves from the metropolis, extended us a brotherly hand and invited us to take our place at the council table of the nations of the globe. Let us give, then, a vote of gratitude to this people, the most powerful nation of the New World."

On January 15, I8I I, the Congress of the United States of America, acting in response to a secret message of President Madison regarding the occupation of the Floridas, passed in secret session the following resolution which was one of the numerous forerunners of the Monroe Doctrine:

"Taking into view the peculiar situation of Spain and of her American provinces; and considering the influence which the destiny of the territory adjoining the southern border of the United States may have on their security, tranquillity, and commerce,-

"Resolved, That the United States, under the peculiar circumstances of the existing crises cannot, without serious inquietude, see any part of the said territory pass into the hands of any foreign power; and that a due regard to their own safety compels them to provide, under certain contingencies, for the temporary occupation of the said territory."

President Madison was always friendly toward his southern neighbors. In determining his attitude toward the increasingly difficult international questions he seemed always to take into his perspective the whole continent. In his annual message to Congress on November 5, I8I I, President Madison declared that attention must be given to the scenes "developing themselves among the great communities which occupy the southern portion of our own hemisphere 
and extend into our own neighborhood. An enlarged philanthropy and an enlightened forecast concur in imposing on the national councils an obligation to take a deep interest in their destinies, to cherish reciprocal sentiments of good will, to regard the progress of events and not to be unprepared for whatever order of things may be ultimately established."

As a result of President Madison's message the first resolution of sympathy for Latin America ever offered in a foreign legislature was passed by the United States Congress on December I0, I8II. It was as follows:

"Whereas, Several of the American Spanish Provinces have represented to the United States that it has been found expedient for them to associate and form federal governments upon the elective and representative plan, and to declare themselves free and independent; Therefore be it

"RESOLved by the Senate and House of Representatives of the United States of America in Congress assembled, That they behold with friendly interest, the establishment of independent sovereignties by the Spanish Provinces in America, consequent upon the actual state of monarchy to which they belong; that as neighbors and inhabitants of the same hemisphere, the United States feel great solicitude for their welfare; and that, when these Provinces shall have attained the conditions of nations, by the just exercise of their rights, the Senate and the House will unite with the Executive in establishing with them, as sovereign and independent states, such amicable relations and commercial intercourse as may require their legislative authority."

Throughout all the fluctuations of the patriot cause in Spanish America, in the years immediately following, in spite of its own severe difficulties, the government of the United States maintained a keen interest in the struggle. In I8I7 a commission composed of Messrs. Rodney, Graham and Bland went to Buenos Aires under instructions which appropriately described the policy of the United States at that time. These instructions were: 


\section{EARLY EFFORTS TOWARD FRIENDSHIP}

"It is by success that the colonies acquire new claims on other powers which it may comport neither with their interest nor duty to disregard. Several of the colonies having declared their independence and enjoyed it for some years, and the authority of Spain being shaken in others, it seems probable that, if the parties be left to themselves, the most permanent political changes will be effected. It therefore seems incumbent on the United States to watch the movement in its subsequent steps with particular attention, with a view to pursue such course as a just regard for all those considerations which they are bound to respect may dictate."

In spite of her deep sympathies the United States Government did not recognize the new Republics until I822. The matter of recognition of the struggling colonies by a country which was itself cordially hated by the reactionary monarchical governments of Europe was not the simple question it would be today. While after a hundred years it is easy to criticise the United States for slowness in action, yet a careful study of all sides of the case seems to give no evidence to question the friendship for Hispanic America, even if wise caution were used, caution which no doubt in the long run strengthened all America in maintaining its independence of Europe.

The first agent to visit the United States to seek recognition for a Latin American nation which had declared its independence was Telésforo de Orea. He was appointed by the new Venezuelan government on July 24, I8 I I, its special agent to the United States to inform that government of the declaration of independence by the "United Provinces of Venezuela" and to solicit the recognition of the new state.

This action by Venezuela served to place more prominently before the government and people of the United States the struggle for independence of their Southern neighbors and brought out many expressions of sympathy.

Notwithstanding the deep appreciation of her heroic struggles, Orea's note of November 6, I 8 I I, to the Secretary of State expressing the hope that the United States would acknowledge the independence of Venezuela did not meet with an immediate response. Monroe, who was then the 
Secretary of State, realized that it would cause an unfavorable reaction, both on his own government and the Venezuelan cause if after a premature recognition Spain should later succeed in reconquering her territory. His cautious policy was soon justified for in July, 1812, Miranda met a decided defeat at the hands of the royalist commander, Monteverde, and Venezuela again was ruled by Spain until Bolivar organized a new revolution and by his astounding success gained the title of Liberator.

The next country, following Venezuela, to ask recognition was the United Provinces of La Plata. Secretary of State Adams, fresh from an extended diplomatic experience in Europe, where he had learned much of Europe's designs on all America, felt it was not expedient for the President to acknowledge their independence at that time and induced thim on several occasions to assume a conservative attitude toward the new states of Latin America. In a letter to President Monroe in August, I8I8, Adams expresses his idea of the principles upon which the government should act, in these words :

"But there is a stage in such contests when the parties struggling for independence have, as I conceive, a right to demand its acknowledgment by neutral parties, and when the acknowledgment may be granted without departure from the obligations of neutrality. It is the stage when independence is established as a matter of fact so as to leave the chance of the opposite party to recover their dominion utterly desperate. The neutral nation must, of course, judge for itself when this period has arrived; and as the belligerent nation has the same right to judge for itself, it is very likely to judge differently from the neutral and to make it a cause or pretext for war. *** If war thus results in point of fact from the measure of recognizing a contested independence, the moral right or wrong of the war depends upon the justice, and sincerity, and prudence with which the recognizing nation took the step. I am satisfied that the cause of the South Americans, so far as it consists in the assertion of independence against Spain, is just. But the justice of a cause, however it may enlist individual feelings 
in its favor, is not sufficient to justify third parties in siding with it. The fact and the right combined can alone authorize a neutral to acknowledge a new and disputed sovereignty."

\section{THE FIGHT FOR RECOGNITION}

If Adams can be charged with being too cautious, because of his European experience, the United States held another great soul, sufficiently daring, sufficiently far-seeing to vie with the great Bolivar himself in his faith in the great future before the Spanish and Portuguese colonies, and willing to stake his all and that of his country in backing their struggle for independence. That man was the idol of the western frontier state of Kentucky, Henry Clay. The work of that great man for Pan American friendship and solidarity must ever be one of the glories of the early history of the United States and the inspiration of all who strive for common understandings and common ideals for all America. For ten years he labored incessantly for recognition by the United States and European governments of the cause of the Spanish-American patriots. As early as 1816 , while the struggle for freedom was at its height in several of the Spanish colonies, Clay, who was at the time Speaker of the House of Representatives, opposed the reduction of certain taxes which had been levied by the United States Government as a result of the War of 1812 , on the ground that "The United States might have openly to take part with the patriots of South America."

In an eloquent speech on March 25, 1818, in the debate upon his proposal to appropriate money for a minister to the United Provinces of La Plata, he called attention to the "immensity and character of the country which Spain was attempting to subjugate:

"Stretching on the Pacific Ocean from about the 4oth degree of north latitude to about the $55^{\text {th }}$ degree of south latitude, and extending from the mouth of the Rio del Norte (exclusive of East Florida) around the Gulf of Mexico, and along the South Atlantic to near Cape Horn, it is about 5,000 miles in length, and in some places near 3,000 in 
breadth. Within this vast region, we behold the most sublime and interesting objects of creation; the loftiest mountains, the most majestic rivers in the world; the richest mines of the precious metals, and the choicest productions of the earth. We behold there a spectacle still more interesting and sublime-the glorious spectacle of 18 millions of people, struggling to burst their chains and to be free.

"In the establishment of the independence of Spanish America, the United States have the deepest interest. I have no hesitation in asserting my firm belief that there is no question in the foreign policy of this country which has ever arisen, or which I can conceive as ever occurring, in the decision of which we have had or can have so much at stake. This interest concerns our politics, our commerce, our navigation. There cannot be a doubt that, Spanish America once independent, whatever may be the form of the governments established in its several parts, these governments will be animated by an American feeling and guided by an American policy. They will obey the laws of the New World, of which they will form a part. $* * *$

"We are their great example. Of us they constantly speak as of brothers, having a similar origin. They adopt our principles, copy our institutions, and in many instances employ the very language and sentiments of our revolutionary papers.

"But it is sometimes said that they are too ignorant and too superstitious to admit of the existence of free government. This charge of ignorance is often urged by persons themselves actually ignorant of the real condition of the people. I deny the alleged fact of ignorance; I deny the inference from that fact, if it were true, that they want capacity for free government; and I refuse assent to the further conclusion, if the fact were true, and the inference just, that we are to be indifferent to their fate. All the writers of the most established authority, Depons, Humboldt, and others, concur in assigning to the people of South America, great quickness, genius, and particular aptitude for the acquisition of the exact sciences, and others which they have been allowed to cultivate. In astronomy, geology, 
mineralogy, chemistry, botany, and so forth, they are allowed to make distinguished proficiency. They justly boast of their Abzate, Velasques and Gama, and other illustrious contributors to science. They have nine universities, and in the City of Mexico, it is affirmed by Humboldt that there are more solid scientific establishments than in any other city even in North America. I would refer to the message of the Supreme Director of La Plata (Pueyrredón) as a model of composition of a State paper, challenging the comparison with any, the most celebrated, that ever issued from the pens of Jefferson or Madison. ***

"We may safely trust to the daring enterprise of our merchants. The precious metals are in South America, and they will command the articles wanted in South America, which will purchase them. Our navigation will be benefited by the transportation, and our country will realize the mercantile profits. Already the item in our exports of American manufacture is respectable. They go chiefly to the West Indies and to South America, and this item is constantly augmenting."

On May 10, 1820, Clay submitted in the House a resolution declaring it to be expedient to provide by law for the sending of ministers to any of the governments of South America that had established and were maintaining their independence of Spain. In the eloquent speech with which he supported this proposal he did not hesitate to examine the subject in all its phases. Even the question of slavery, which had persistently disturbed the debates of the session, he did not forbear to discuss. Adverting to an intimation that the people of South America were "unfit for freedom," he affirmed that they were in some particulars "in advance of us." In one particular they were indeed "greatly in advance of us"; that was that "Granada, Venezuela and Buenos Aires had all emancipated their slaves." He "rejoiced that circumstances were such as to permit them to do it." Nor had they, he said, neglected education. They had "fostered schools." Newspapers were numerous. He had, he affirmed, never seen a "question discussed with more ability than in a newspaper of Buenos Aires, whether a federative 
or consolidated form of government was best." Rising then to the height of his argument, he exclaimed:

"It is in our power to create a system of which we shall be the center, and in which all South America will act with us. In respect to commerce, we should be most benefited. $* * *$ We should become the center of a system which would constitute the rallying point of human wisdom against all the despotism of the Old World. $* * *$ In spite of our coldness towards them, $* * *$ I have no earthly doubt, if our government would take the lead and recognize them, that they would become yet more anxious to imitate our institutions, and to secure to themselves and to their posterity the same freedom which we enjoy."

The opinion of the friends of freedom in Europe was, he declared, that the policy of the United States had been "cold, heartless, and indifferent towards the greatest cause which could possibly engage our affections and enlist our feelings in its behalf." He would no longer justify this impression. He would break the commercial and political fetters by which the New World had so long been confined. "Let us," he exclaimed, "become real and true Americans, and place ourselves at the head of the American system."

Clay's resolution was carried by a vote of 80 to 75 . The resolution, however, only expressed an opinion in favor of diplomatic representation, but did not actually provide for it. A year later, on February 9, I82I, a motion for a suitable appropriation was lost by only seven votes. On the following day, however, he presented a resolution that the House "participates with the people of the United States in the deep interest which they feel for the success of the Spanish provinces of South America, which are struggling to establish their liberty and independence; and that it will give its Constitutional support to the President whenever he shall deem it expedient to recognize the sovereignty and independence of any of the said provinces."

This resolution was finally carried and a committee appointed to lay the matter before the President. 
The long struggle was ended and victory was won by this moderate champion of Pan Americanism!

Monroe considered this action as an endorsement of the policy which his administration had followed and stated that "The object of the executive has been to throw the moral weight of the United States into the scale of the revolutionary movement, without such a deep compromitment as to make them a party on that side. With that view the mission to Buenos Aires was adopted, all the messages to Congress were drawn, and other measures have been since pursued."

\section{RECOGNITION AND THE PERIOD OF GOOD WILL}

In a special message to Congress on March 8, I 822, President Monroe reviewed the policy of the United States toward the Latin American revolution. He declared that the countries of La Plata, Chile, Peru, Colombia and Mexico were in the full enjoyment of their independence; that there was not the most remote prospect of their being deprived of it ; and that the new governments had now a claim to recognition by other powers, which ought not to be resisted. "When we regard, then, the great length of time which this war has been prosecuted, the complete success which has attended it in favor of the provinces, the present condition of the parties, and the utter inability of Spain to produce any change in it, we are compelled to conclude that its fate is settled and that the provinces which have declared their independence, and are in the enjoyment of it, ought to be recognized."

The Committee on Foreign Relations, to which the President's message was referred, reported on March 19, 1822, that the Spanish American nations were, in fact, independent, and proposed two resolutions: first, that the House should concur with the President that the American provinces of Spain which had declared and were enjoying their independence "ought to be recognized by the United Sitates as independent nations"; and, second, that the Comnittee on Ways and Means should report a bill appropriating a sum to enable the President "to give due effect to such recognition." 
This report provoked an animated debate in the House. David Trimble of Kentucky enthusiastically declared that the proposal for the acknowledgment of Spanish American independence was "a message of good tidings to twenty millions of freemen. $* * *$ Shall the last of the revolutionary heroes leave the high station which he fills, without officiating, in his robes of office, at the baptism $* * *$ of all the new Republics in America?*** Let us boldly fill up our page of destiny, and leave no blank for after-time to write an execration of our memory. Let us make acknowledgment at once $* * *$ and laugh the fear of despots into scorn."

May 4, I822, President Monroe signed a bill which appropriated $\$ 100,000$ to defray the expenses of "such missions to the independent nations of the American continent" as the President may deem proper, which was, in effect, an announcement that the Government of the United States intended to acknowledge the independence of the revolting colonies of Spain in America. Thus she became the first government, with the exception of Brazil, to extend the hand of welcome to these young countries as members of the society of nations. The storm of protest with which this announcement was greeted in Europe was sufficient to show what the United States was willing to risk in order to encourage the young southern neighbors and to act as their sponsors before an unsympathetic world.

The first step in formal recognition was the presentation to President Monroe by Secretary Adams of Manuel Torres as chargé d'affaires of Colombia on June I9, I822. Torres was in very poor health at the time, scarcely having strength to walk alone, and was greatly affected by his reception. $\mathrm{He}$ spoke on the great importance of the event to the Republic of Colombia and of his assurance that it would give extraordinary gratification to Bolívar. President Monroe sat down beside Torres, "and spoke to him with kindness which moved him even to tears. The President assured him of the great interest taken by the United States in the welfare and success of his country, and of the peculiar satisfaction with which he received him as its first representative."

About the same time that President Monroe had signi- 
fied to Secretary Adams his intention to receive Torres officially, Adams wrote to José M. de Herrera, the Mexican Secretary of Foreign Affairs, of the President's willingness to receive an envoy from Mexico. A change in Mexican affairs, ensuing shortly afterward and which resulted in the proclamation of Iturbide as Emperor in May, 1822, made the United States somewhat reluctant to carry out the proposal, and Joel R. Poinsett was sent to Mexico City to investigate conditions. Recognition could not be long delayed, however, for in September Iturbide appointed José Manuel Zozaya as Minister Plenipotentiary to Washington, under instructions to propose treaties of friendship, alliance, commerce and adjustment of boundaries. Arriving in Washington on December 10, I822, he was presented to President Monroe two days later as Envoy Extraordinary and Minister Plenipotentiary from the Mexican Empire.

On June 27, 1823, the United States Senate confirmed the nomination of Richard C. Anderson as Minister to Colombia, C. A. Rodney as Minister to Argentina and Herman Allen as Minister to Chile. On June I, I825, Joel R. Poinsett was relieved as Minister at Mexico City. A few months later chargés d'affaires were sent to Lima and Central America. Thus were begun in those critical days the formal diplomatic relations with the young American democracies which for more than a century have remained unbroken, with the single unfortunate exception of the Mexican War of $1846-47$. It is thus seen that just as in Hispanic America the great leaders had thought much of continental solidarity, so also the leading statesmen, as well as the common people, of the United States were in the early days most sympathetic toward their southern neighbors. In these first days there was neither suspicion on the part of the South nor designs on the part of the North. The constitutions of all the Latin American republics were modeled upon that of the United States, which country was generally referred to by some such term as "our great sister of the North," the "model republic," etc.

After the southern republics secured their freedom and 'we, by means of the Monroe Doctrine, succeeded in keeping Europe from encroaching on American territory, we more 
or less forgot the rest of America in our intense desire to round out and develop our own great territory.

The only other American country with which we had any particular dealings in that period was our next-door neighbor, with whom we came in contact in expanding our own national life. Our relations with Mexico started out splendidly. On November 30, I82I, the Mexican Minister of Foreign Affairs, José M. de Herrera, sent the first diplomatic commission to the Washington government, and among other things said:

"The people of Mexico are desirous of being united to all governments by means of friendly alliances and connections. The United States of North America have a preferable right to demand of the Mexican Empire these considerations, the more just and reasonable because they are supported by well-known maxims of policy. Even nature herself has separated these nations from Europe by immense seas and placed them upon the same continent that they might make common cause in reciprocally supplying their necessities and cooperating for their mutual felicity."

\section{THE DISASTROUS WAR WITH MEXICO}

Unfortunately these cordial words did not prove prophetic of future relations between the two countries. Minister Poinsett got mixed up in internal politics in Mexico and came to be cordially hated by many Mexicans who resented his seeming endeavor to conduct their government for them. The second American Minister, Anthony Butler, was even more objectionable, because of his continued insistence upon buying Texas after Mexico had told him it was not for sale.

Border claims early came to be a troublesome issue. The independence of Texas and its later annexation to the United States widened the breach and prepared for the war declared by the United States on May I3, I846. Most historians of the United States agree that this was an unjust war largely caused by the selfish designs of American politicians. Latin Americans who, justly so, criticize this war 
should remember that the best elements in the United States have equally condemned it. General Grant called it an "unholy war," saying:

"For myself, I was bitterly opposed to the measure (the annexation of Texas) and to this day regard the war which resulted as one of the most unjust ever waged by a stronger against a weaker nation. It was an instance of a republic following the bad example of European monarchies, in not considering justice in their desire to acquire additional territory."

It was Abraham Lincoln, the great defender of weak peoples, who led the fight in Congress itself against the war. Lincoln argued that the war was unnecessarily and unconstitutionally begun by the President of the United States for the following reasons:

That the President had sent General Taylor into an inhabited part of the country belonging to Mexico and not to the United States and had thereby provoked the first act of hostility, in fact, the commencement of the war; that the place, being the country bordering on the east bank of the Rio Grande, was inhabited by native Mexicans born under the Mexican government and had never submitted to or been conquered by either Texas or the United States, nor transferred to either of them by treaty; that although Texas claimed the Rio Grande as her boundary, Mexico had never recognized it and neither Texas nor the United States had ever enforced it and there was a broad desert between that and the country over which Texas had actual control; that the country where hostilities commenced having once belonged to Mexico must remain so until it was somehow legally transferred, which had never been done.

Mr. Lincoln thought the act of sending an armed force among the Mexicans was unnecessary inasmuch as Mexico was in no way molesting or menacing the United States, and that it was unconstitutional because the power of levying war is vested in Congress and not in the Executive. He thought the principal motive for the act was to divert public attention from the surrender of "fifty-four forty or fight" to 
Great Britain in the Oregon boundary controversy. In addressing Congress Lincoln said:

"Now, sir, for the purpose of obtaining the very best evidence as to whether Texas had actually carried her revolution to the place where the hostilities of the present war commenced, let the President answer the interrogatories I proposed, or some similar ones. Let him answer, fully, fairly, and candidly. Let him answer with facts, and not with arguments. Let him remember he sits where Washington sat, and so remembering, let him answer as Washington would answer. As a nation should not, and the Almighty will not, be evaded, so let him attempt no evasion-no equivocation. And if, so answering, he can show that the soil was ours where the first blood of the war was shed-that it was not within an inhabited country, or, if within such, that the inhabitants had submitted themselves to the civil authority of Texas or of the United States, and that the same is true of the site of Fort Brown, then I am with him for his justification. $* * *$ But if he cannot or will not do this-if on any pretense or no pretense he shall refuse or omit it then I shall be fully convinced of what I more than suspect already - that he is deeply conscious of being in the wrong; that he feels the blood of this war, like the blood of Abel, is crying to Heaven against him; that originally having some strong motive-what, I will not stop now to give my opinion concerning - to involve the two countries in a war, and trusting to escape scrutiny by fixing the public gaze upon the exceeding brightness of military glory-that attractive rainbow that arises in showers of blood-that serpent's eye that charms to destroy-he plunged into it, and has swept on and on till, disappointed in his calculation of the ease with which Mexico might be subdued, he now finds himself he knows not where. How like the insane mumblings of a fever dream is the whole war part of his last message! At one time urging the national honor, the security of the future, the prevention of foreign interference, and even the good of Mexico herself as among the objects of the war; at another telling us that 'to reject indemnity, by refusing to accept a cession of territory would be to abandon all our 
just demands, and to wage the war bearing all its expenses, without a purpose or definite object.'

"*** Again, it is a singular omission in this message that it nowhere intimates when the President expects the war to terminate. At its beginning, General Scott was by this same President driven into disfavor, if not disgrace, for intimating that peace could not be conquered in less than three or four months. But now, at the end of about twenty months $* * *$ this same President gives us a long message, without showing us that as to the end he himself has even an imaginary conception. As I have said before, he knows not where he is. He is a bewildered, confounded, and miserably perplexed man. God grant he may be able to show there is not something about his conscience more painful than all his mental perplexity."

CONSEQUENCE OF THE WAR WITH MEXICO

The war between the United States and Mexico marks the dividing of the ways between North and Hispanic America. From that time on, the southerners began to be afraid of the nation that was not only greater than they, but now seemed to be willing to use its strength to exploit its weaker neighbors. This change of sentiment is widely recognized by Hispanic American writers. Ex-President Bonillas, of Honduras, says :

"Ever since the Mexican War, the Monroe Doctrine, instead of being considered as a guarantee of American independence by the Latin American countries, has been regarded as a menace to their existence."

\section{The Venezuelan historian, Blanco Fombona, says:}

"The United States were, until their war with Mexico, a people without militaristic or imperialistic ambitions, the model and the home of civil liberty. All South America admired her with the same ardor with which today they hate her."

Manuel Ugarte in a lecture in Columbia University a short time ago said: 
"During the early times, from the eve of the eighteenth to the middle of the nineteenth century, the two groups (Latin Americans and Anglo-Saxon Americans) maintained themselves in a spirit of fraternity and mutual respect. $* * *$ It was in these times of austerity and strict logic when we Latin Americans began to admire the United States. The vital breath of equity that seemed to animate the young nation inspired our fullest and most sincere admiration. When the United States obtained from Spain the sale of Florida and from France the cession of Louisiana we did not picture in that aggrandizement anything more formidable than a just desire to preserve collective independence, barring from the Continent the last vestige of European domination. But in the victory of yesterday is discernible a tendency to become the executioner of today and the emancipated subject, the freed colony, once fortified, forgot the declarations of its heroes and began in turn to abuse its powers. The annexation of Mexican territory in I $845-48$ was the revelation of a policy which was afterward to extend itself in a lamentable manner. A specter of domination and despoilment appeared to float over our undefended countries. Several countries succumbed, and injustice has lately become so accentuated that we turn to the United States today to cry out: 'The same injustice which the mother country perpetrated against you, you are now committing against us; and we have no fault save that which you had even yesterday, our weakness.'

It was not simply the Mexican War itself that brought about this change of sentiment toward the United States, but it was the development and boastful use of the term "Manifest Destiny" which North American politicians and editors began at that time to flout to the world. There was at that period, and continues to be, far too much of the jingo spirit illustrated by the following words attributed by Eduardo Prado of Brazil to Mr. Everetts, spoken at a dinner presided over by General Grant:

"America for the Americans! Yes. But we understand it means America for the North Americans. Let us begin 
with Mexico, of which we have already taken a part. We must now take her entirely. Central America will follow, whetting our appetites for South America. Looking at the map we see that South America has the shape of a ham. Uncle Sam's favorite dish is ham. Our starry banners are sufficient to reach from one glorious ocean to another. Some day it will float alone and triumphant from the North Pole to the South."

Dr. Ernesto Quesada, in recent lectures before the University of Buenos Aires, has brought together a long series of quotations from eminent North Americans in the administrations of Polk, Taylor, Pierce and Buchanan, which spread alarm through Latin America, such as the following, uttered in a notable session of the United States Congress in 1857 by Senator Douglas:

"Whatever the interests of the United States dictate should be considered the law of the land, and other nations must accept it, for the conditions, limitations and restrictions of former days cannot prevail in view of the manifest destiny of our nation."

President Pierce, who had a scheme to take over Yucatan, said:

"The policy of my administration will not be controlled by any timid forebodings of evil from expansion. Indeed, it is not doubted that our attitude as a nation and our position on the globe render the acquisition of certain territory, not within our jurisdiction, eminently important for our protection."

Since this book is not a historical study, but the presentation of certain outstanding developments related to problems of American unity, time will not be taken to consider in detail the history of the United States' relations to Latin America between the Mexican War and the First Pan American Congress in 1889 . The most significant events in InterAmerican relations, from the standpoint of the United States, were the Walker Expedition to Central America, the 
diplomatic intervention of the United States in the War between Chile and Peru and Bolivia, the development of the idea of Manifest Destiny, the demand on Napoleon to withdraw his troops from Mexico, and the mediation of the United States between Spain and South America in their war of the sixties, which events, except the latter two, augmented the fear of the growing power of the United States.

Summarizing we may say that in the early days the Americas, both North and South, had great interest in one another, and a common desire for friendship and helpful relations; but that the Mexican War started a suspicion and fear of the United States among the Hispanic American countries, which grew to such proportions that it became the outstanding phenomenon in American international relations. If fact as well as appearance has sometimes justified this suspicion, we at least must realize that there have always been great men in the United States, who, just as Lincoln protested against the Mexican War, have raised their voices against anything that looked like taking advantage of a weaker people. In fact, all through our history we have been fortunate enough to have great outstanding souls like Henry Clay who in the broadest continental sense have been "animated by an American feeling and guided by an American policy."

Sources of Further Information on Early Efforts of the United States Toward American Friendship

Blanco-Fombona, R.: Grandes Escritores de América.

Latané: The United States and Latin America, Chapters II and VIII.

Lima, M. de Oliveira: Relations of Brazil with the United States. Loвo, Helio: Cousas Diplomaticas.

Lockey, Jos. B.: Pan-Americanism, Its Beginnings.

Manning: Early Diplomatic Relations with Mexico.

MoORe, John B.: Henry Clay and Pan Americanism, Bulletin

American Association of International Conciliation.

Prado, Eduardo: A Illusao Americana.

Robinson, James Spence: Recognition of Hispanic America by the United States. 


\section{Chapter V}

\section{THE MONROE DOCTRINE AND LATIN AMERICA}

The Monroe Doctrine has been for the American continent at once the most powerful unifying force and the greatest cause of division and misunderstanding. From the standpoint of the United States it might be called "the American fetish." Along with the Washington doctrine of no entangling alliances it has been the cardinal principle of our foreign policy. As Jefferson said, "It is the offspring of the American Revolution and the most momentous question offered to my contemplation since the Independence." Like many an important principle, it has through the passage of time come to be more of a sentiment than a principle or a policy. And like every sentiment it has as many interpretations as there are kinds of persons who deal with it. To the average North American it means the divine right-as sacred and clear as was ever such right to any monarch-to act as the big brother of all the other American nations. This means first to protect them from all outside interference, and, second, to help them in their own difficulties when they seem to have lost their way politically, financially or economically. It makes no difference what question concerning Latin America may arise in this country or what difficulty may arise in the South which affects the life of the United States, many immediately call out the Monroe Doctrine as arbiter.

"Why has General Crowder gone to Cuba?" was the question appearing recently from a reader of one of our prominent dailies. "It is due to the Monroe Doctrine, which makes us responsible for fair elections in Cuba," answered the all-wise editor. And no doubt the questioner was entirely satisfied with this simple answer. (Because we North Americans are so sure of our generous desire to help all who 
are in need, and so sure of our superiority to all the rest of America, many of us suppose that all Latin American governments must be highly appreciative of the help which the Monroe Doctrine makes us in honor bound to give. J Of course, if the young sinner proves recalcitrant, we, as the unselfish and more experienced brother, desirous only of the other's improvement, must compel him to be good. If anyone questions at all whether this is the right procedure he is met with "We do not discuss the Monroe Doctrine, we enforce it."

( It is this attitude of the North American toward the Doctrine, rather than the Doctrine itself, that explains why it has been such a cause of division and misunderstanding.) In other words, it is a certain interpretation of the Doctrine (a false interpretation, I believe) and not the Doctrine itself, that is so much opposed in Latin America.) Indeed, the original Monroe Doctrine was well received in the South, and from that time until today the declaration in its original sense has been approved by the best minds of Hispanic America.)

In these days when all international relations are in flux and when every principle of life is being stripped of its accretions and thoroughly examined, we need a fresh study of the original purposes of the Doctrine, which has been the basis of more discussion and more varied interpretation than any other document ever issued by the president of a republic.

\section{ORIGIN OF THE DOCTRINE}

The substance of this Doctrine, which calls for the exclusion of European colonization and interference in American affairs, had often been stated before the Monroe pronouncement both by North American and South American statesmen. But in I822 it seemed probable that the efforts of the Holy Alliance to strangle all democratic development in Europe might be extended to the western hemisphere. So Monroe and his advisors felt it necessary to take steps to forestall any such movement. (Great Britain was also opposed to the extension of the influence of the Holy Alli- 
ance to America, for with the reconquest of Spanish America large part of the conquered territory might be turned over to France and the large commerce which had been diverted to Great Britain on account of the revolt of the colonies would be seriously affected. )

At this time the British Foreign Secretary was the celebrated Canning, one of the most astute men that ever held that office, a man who exercised almost a charmed influence over Latin American statesmen of those days, as well as an exaggerated place in the judgments of later Latin American historians. His proposal to the United States of an agreement that would checkmate the influence of the Alliance (and incidentally that of the United States) in Hispanic America, has led many historians to erroneously credit him with originating the Monroe Doctrine. At least two strong proofs of the falsity of the "Canning myth," as it has rightly been called, are these: First, the doctrine that Europe must not meddle in American affairs had been stated many times, both in North and South America, before it was formally announced by Monroe. Second, the Doctrine had no more strenuous opponent than Canning himself. He later said, "It is not easy to say how much the previous British propositions influenced the message, but the doctrine, if such it can be called, of the presidential message prohibiting all future colonization on the American continent, is absolutely unacceptable to my government and to France. This extraordinary principle will be combated by my government with all its force." The private correspondence of Canning with some of his friends shows that he did everything possible to combat the doctrine. In fact, Great Britain has generally been its strong opponent, Lord Salisbury writing to Secretary Olney during the Venezuelan controversy that the Monroe Doctrine was not entitled to anyone's respect.

When Canning was asked why he had not sought to prevent the French invasion of Spain, he said, "I sought for compensation in another hemisphere. $* * *$ I resolved that if France had Spain it should not be Spain with the Indies. I called the new world into existence to redress the balance of the old." This, of course, was nonsense, as the Spanish 
American colonies had won their independence by their own efforts and had been recognized by the United States as independent governments two years before Great Britain took any action in the matter. Canning was so irritated by the Monroe Doctrine that he did not permit the United States to participate with Great Britain and Russia in the settlement of the Alaskan boundary question. As long as he remained in public life he opposed the Monroe Doctrine in every possible way, and continually impressed upon the Latin American republics the advantage to them of an alliance with Great Britain over an alliance with the United States.

And yet, with all this evidence to the contrary, great students like Alberdi have believed this Canning myth and attribute the success of the colonies' struggle for independence to the friendship of Great Britain. Many Latin Americans erroneously hold this to be a very important point in showing what they claim was the indifference of the United States to Hispanic America's struggle for independence.

Canning did send to Minister Rush of the United States, who was in London at the time, five proposals concerning the recognition of the independence of the Spanish colonies and their protection from the schemes of the Holy Alliance, which he suggested the two governments might jointly announce. But Monroe, advised by his Secretary, Adams, chose rather to announce a purely American doctrine that would be sustained by American authority. This is a most important matter for Latin Americans to understand. And for North America it is imperative to realize that the circumstances surrounding the announcement of the Doctrine all point to the fact that our statesmen did not have the least idea that we were providing for ourselves any special privileges in America. As John Quincy Adams, the man who historians believe worded the Doctrine itself, wrote in his diary, "Considering the South Americans as independent nations, they themselves, and no other nation, had the right to dispose of their condition. We have no right to dispose of them, either alone or in conjunction with other nations. Neither have any other nations the right to dispose of them without their consent." 
The most salient features of the famous Doctrine, which was contained in President Monroe's annual message to Congress on December 2, 1823, are the following:

"The occasion has been judged proper for asserting as a principle in which the rights and interests of the United States are involved, that the American constituents, by the free and independent condition which they have assumed and maintain, are henceforth not to be considered as subjects for future colonization by an European power.

"The citizens of the United States cherish sentiments the most friendly in favor of the liberty and happiness of their fellow-men on that side of the Atlantic. In the wars of the European in matters relating to themselves we have never taken any part, nor does it comport with our policy to do so. It is only when our rights are invaded or seriously menaced that we resent injuries or make preparation for our defense. .With the movements in this hemisphere we are, of necessity, more immediately connected, and by causes which must be obvious to all enlightened and impartial observers. The political system of the allied powers is essentially different in this respect from that of America. This difference proceeds from that which exists in their respective Governments. And to the defense of our own, which has been achieved by the loss of so much blood and treasure, and matured by the wisdom of their most enlightened citizens, and under which we have enjoyed unexampled felicity, this whole nation is devoted. We owe it, therefore, to candor, and to the amicable relations existing between the United States and those powers, to declare that we should consider any attempt on their part to extend their system to any portion of this hemisphere as dangerous to our peace and safety. With the existing colonies or dependencies of any European power we have not interfered and shall not interfere. But with the Governments who have declared their independence, and maintained it, and whose independence we have, on great consideration and on just principles, acknowledged, we could not view any interposition for the purpose of op- 
pressing them, or controlling in any other manner their destiny, by any European power, in any other light than as the manifestation of an unfriendly disposition toward the United States.

"The late events in Spain and Portugal show that Europe is still unsettled. Of this important fact no stronger proof can be adduced than that the allied powers should have thought it proper, on any principle satisfactory to themselves, to have interposed, by force, in the internal concerns of Spain. To what extent such interposition may be carried, on the same principle, is a question in which all independent powers whose Governments differ from theirs are interested, even those most remote, and surely more so than the United States."

\section{HOW THE DOCTRINE WAS RECEIVED IN LATIN AMERICA}

What was Latin America's attitude to this new Doctrine? - Bolívar seems not to have heard of it for quite a while. He never really made any long pronouncement upon it. $\mathrm{He}$ did, however, applaud the declaration, and in a letter to the - Spanish general whom he was endeavoring to persuade to join the liberal cause, said: "England and the United States protect us. These two nations which form today the only two powers in the world, will not permit that help be given to Spain."

The Brazilian government, through its Minister, Rebello, proposed an alliance between the United States and Brazil which the other Hispanic American republics were invited to join. She invoked the message of Monroe and the necessity of making impossible any tendency of the mother countries to reconquer their old colonies, observing that "the United States is obliged to place in practice the principle announced in the message (Monroe) giving proof of the generosity and the consistency which animates that government, without counting the eventual sacrifice of men and money."

On April 6, I824, Vice-President Santander sent a message to the Colombian Congress in which he referred to the Monroe Doctrine as follows: 
"The President of the United States has lately signalized his administration by an act eminently just and worthy of the classic land of liberty; in his last message to the Congress he has declared that he will regard every interference of any European power directed to oppress or violate the destinies of the independent governments of America as a manifestation of hostile disposition toward the United States. That government considers every attempt on the part of the Allied Powers to extend their system to any portion of the American hemisphere as perilous to the peace and safety of the United States. This policy, consolatory to human nature, would secure to Colombia a powerful ally should its independence and liberty be menaced by the Allied Powers. As the Executive cannot regard with indifference the march which the policy of the United States has taken, it is sedulously occupied in reducing the question to decisive and conclusive points."

About the same time Santander addressed a note to Secretary Adams in which he said:

"My Government has received with the greatest pleasure the message, worthy of its author, which expresses the sentiment of the country over which he presides."

He even went so far as to propose an alliance between the United States and Colombia to sustain the principles of the Monroe Doctrine.

From Buenos Aires United States Minister Rodney wrote on February IO, I824, to President Monroe that his message had been received two days before, that it had inspired the Argentine people, and that it would have the "happiest effect throughout the whole Spanish provinces." On May 22nd he wrote Secretary Adams that the frank and firm message of the President had been productive of happy effects; but that he looked not so much to its temporary influence as to its permanent operation. "We had it immeciately translated," he wrote, "into the Spanish language, frinted and generally circulated in this quarter, Peru and ('hile." 
On December 16, 1824, the congress of the United Provinces of Rio de la Plata opened its sessions at Buenos Aires. In a message of the government of Buenos Aires, laid before that body on the same date, the American policy of the United States was referred to in the following terms:

"We have fulfilled a great national duty toward the republic of the United States of North America. That republic, which, from its origin, presides over the civilization of the New World, has solemnly acknowledged our independence. - It has at the same time made an appeal to our national honor by supposing us capable of contending singlehanded with Spain; but it has constituted itself the guardian of the field of battle in order to prevent any foreign assistance from being introduced to the aid of our rival."

Governor Las Heras, of Buenos Aires, on receiving United States Minister Forbes a little later, said:

"The Governor of the United Provinces recognizes the importance of the two principles which the President of the United States has announced in his message to Congress and, convinced of the usefulness of their adoption by each of the states of this continent, will consider it his duty to back them, and for this purpose will accept any opportunity that is presented."

Chile gave a most genuine response to President Monroe's message. The papers of Santiago seemed to discover in the Monroe Doctrine a frank and explicit promise of effective protection for the Spanish American republics against the political combinations and military projects of European monarchs. A delegate of the Chief Executive, upon the occasion of receiving $\mathrm{Mr}$. Allen, the newly-appointed Minister of the United States to Chile, expressed the gratitude of his government for the recognition of the independence of the new states and for the recent declaration of President Monroe which placed them beyond the reach of the coalitions of European monarchs.

The cordial declarations of the Foreign Office of the Cen- 
tral American Government in 1825 , which heartily approved the Doctrine, have been cited in another chapter.

It would be easy to present other indorsements of the Monroe Doctrine by the Latin American countries in those early days, but these are sufficient to show that at that time they had no idea of anything being involved in the doctrine which made it dangerous to Latin America. It will be remembered that in the call for the Panama Congress it was proposed to make the Monroe declaration a common principle of all the American governments. This is one of the strongest indications that the correct interpretation of the Doctrine rejects the inference that the United States reserves to itself the privilege of doing the things she will not suffer Europe to do. If this earlier interpretation had been retained in practice the present bitterness against the Doctrine would never have developed in Latin America.

The Monroe message states very clearly the three following propositions : first, that there shall be no future colonization in America by European powers; second, that there shall be no extension of the monarchical system to republican America; third, that the United States will defend the independence of these American countries against European aggression. During the years that followed we seem to have added two corollaries to these three propositions: that European governments must not acquire any of the American governments' territory, even with the consent of the nation involved or by the adjustment of boundaries; and that nonAmerican governments cannot occupy any portion of the American republics even temporarily for the satisfaction of any kind of claims against these republics. The first three of these proposals are the original Doctrine. The latter two are interpretations allowed by the Doctrine and which have developed out of recent experience in dealing with the Caribbean countries.

\section{INTERPRETATIONS OF THE DOCTRINE}

One of the greatest questions most often debated concerning the Doctrine is whether or not it is a purely selfish one, : innounced merely to protect the United States, or designed 
as one of those altruistic services which we North Americans like to think we are doing to help smaller nations. Let us listen to what some present North Americans say about that phase of the subject. Mr. Root says:

"The Doctrine is not international law, but it rests upon the right of self-protection and that right is recognized by international law. The right is a necessary corollary of independent sovereignty. It is well understood that the exercise of the right of self-protection may and frequently does extend in its effect beyond the limits of territorial jurisdiction of the state exercising it. $* * *$ The most common exercise of the right of self-protection outside of a state's own territory, and in time of peace, is the interposition of objection to the occupation of territory, of points of strategic military or maritime advantage, or to indirect accomplishment of this effect by dynastic arrangement. $* * *$ Of course each state must judge for itself when a threatened act will create such a situation. If any state objects to a threatened act and the reasonableness of its objection is not assented to, the efficacy of the objection will depend upon the power behind it.

"It is doubtless true that in the adherence of the American people to the original declaration there was a great element of sentiment and sympathy for the people of South America who were struggling for freedom, and it has been a source of great satisfaction to the United States that the course which it took in 1823 concurrently with the action of Great Britain played so great a part in assuring the right of selfgovernment to the countries of South America. Yet is it to be observed that in reference to the South American Governments, as in all other respects, the international right upon which the declaration expressly rests is not sentiment or sympathy or a claim to dictate what kind of government any other country shall have, but the safety of the United States."

\section{Mr. John Bassett Moore says:}

"The Monroe Doctrine was in its origin a defiance to 


\section{THE MONROE DOCTRINE AND LATIN AMERICA 159}

those who would suppress independent governments and restore the system of commercial monopoly and political absolutism on the American continents. It was in this sense that it found an enthusiastic response in popular opinion."

Ex-President Taft has seen this point very clearly and says :

"The Monroe Doctrine was proclaimed for the purpose of upholding the territorial dignity and political independence of the nations of South and Central America. It binds the United States to the exact course which the League of Nations demands of all nations."

\section{Mr. Henry W. Taft says :}

"The Monroe Doctrine is not a principle of international law. It is a national policy based on the right of every nation to protect itself against acts tending to embarrass it in preserving its own national interests or political institutions. It is founded upon the same right as the familiar concert of European powers, except that it affects a greater number of nations more widely separated geographically, and is asserted by a single powerful nation, able, without the sanction of treaty stipulations, to maintain it. [It does not become effective so much by the acquiescence of the American nations subject to its operation as from its recognition by nations of other parts of the world as a political policy which cannot be disregarded by them except at the risk of war with the United States."

\section{Mr. John Bigelow says:}

"In order properly to appreciate the significance of the Monroe Doctrine it must be clearly recognized that it was designed primarily for the protection of the United States, the safeguarding of its territory and political institutions, the effect of which would be, indirectly, to work to the advantage of the Latin American countries by affording 
them the opportunity to work out their problems without interference from European powers."'

Secretary of State Lansing gave the Senate the following account of the conversations which led to the Lansing-Ishii agreement :

"Then it was during the same interview that we mentioned 'paramount interests,' and he (Ishii) made a reference to the Monroe Doctrine of the Far East; and I told him that there seemed to be a misconception as to the underlying principle of the Monroe Doctrine; that it was not an assertion of primary or paramount interest by the United States in its relation to other American republics; that its purpose was to prevent foreign powers from interfering with the separate rights of any nation in this hemisphere and that the whole aim was to preserve to each republic the power of self-development. I said further that so far as aiding in this development the United States claimed no special privileges over other countries."

\section{Rear-Admiral Chester says :}

"The first principle of the Monroe Doctrine-self-preservation-is axiomatic and immutable, and all other considerations must give way to it. The second principle, like the constitution of a country, is amenable to changes and amendments that will bring it into accord with new conditions that may arise in the country. The question now, therefore, is, do the same conditions prevail on the western continent today as in 1823 ? *** Many of the twenty other American Republics are no longer the weaklings they were when the policy was formulated, but are now'strong enough to share-the common defense of the continent. We cannot, however, with propriety form an alliance, for that word has been tabooed by an unwritten law of the land, but we can engage in an 'entente,' as foreigners call it, with the republics of South America that 'will give them a share in the responsibility of maintaining a policy which looks to the good of all parties concerned."

As Admiral Chester says, the Doctrine is partly selfish 
and partly altruistic, as every natural principle should be. It seems very natural to suppose that the United States, being a weak nation in the early days, was particularly interested in protecting herself and also in advancing the great idea of democracy of which she was the pathfinder. Democratic government she selfishly and unselfishly desired to see grow - selfishly in that the development of such government on the American continent would tend to strengthen her own life, unselfishly in that she wished to encourage and assist other small nations to realize the same ideal.

A more practical question concerning the application of the Monroe Doctrine is the extent to which the United States assumes responsibility before the world for the shortcomings of the other American nations. If we say to Europe, "You are to keep completely out of this continent," how far do we expect to see to the just settlement of European complaints against those countries? Consider, for example, the matter of the collection of debts. If we will not let France enter Santo Domingo and take a couple of ports in payment of a $\$ 10,000,000$ debt, how far shall we interfere to make Santo Domingo pay? If an English subject is killed in Mexico and we do not allow England to obtain satisfaction by seizing Mexican territory, how far are we to assume the authority to punish Mexico and force her to deal fairly with England?

We have stated (Roosevelt said it, and it has been intimated many times by our government) that we will not keep European governments from collecting their debts in the American republics. In fact we have permitted them to take measures to enforce payment of such debts as long as this did not mean territorial acquisition by them. At the time when intervention in Mexico was begun, with the announced purpose of collecting debts which she owed Great Britain, France and Spain, the United States was invited to join with them. The situation was tried out to ascertain our attitude, and Secretary Seward wrote that the United States had no objection to these countries collecting their debts from Mexico. When it came to the establishment of a monarchy in Mexico, however, our attitude was very different. 
We have never agreed with certain Latin American statesmen that debts should never be collected forcibly. We have adopted the Hague agreement that the question of debts of this kind shall be arbitrated, but we have undertaken to use moral suasion and more recently have actually assumed responsibility for managing the finances of certain republics in order to save them from a foreign foreclosure. We have thus assumed a protectorate over both Santo Domingo and Haiti because it was claimed that these countries were likely to be seized by European countries for nonpayment of debt. But we have still to determine how far we will go in straightening out the financial difficulties of Latin. American countries that seem to be in danger from European creditors.

The precedent of Santo Domingo, Haiti and Nicaragua seems to indicate pretty clearly that, at least in the Caribbean, or what Admiral Chester calls the "larger Panama Canal Zone," we will take action before risking that of any foreign country. Indeed, diplomatic aid in resuscitating the finances of Honduras, Cuba, Costa Rica and possibly Mexico is now being extended by the United States, although in the case of Mexico the proceedings are still in the formative stage. It is interesting to note that the shift in world credit due to the war makes it altogether probable that the United States will itself more and more assume the rôle of creditor to these republics and that problems in connection with payment of debts will be given an entirely new turn. European nations are not in position to finance foreign governments to any great extent, however profitable it might be.

It has been suggested by some thoughtful students that the Monroe Doctrine should be limited to Caribbean countries or at least those north of the Amazon, for the reason that the zone of defense of the Canal and of the continental United States extends no further than that, and also for the reason that the countries further south have grown strong in their own power and neither need nor appreciate our proffered protection. While a formal pronouncement of any such limitation of the Doctrine will probably never be made, it is almost certain that its application will be limited 
' to this northern zone, as has been the case in the past. It may well be recalled in this connection that even when England and France intervened in Argentina and Spain in Chile and Peru, the United States did no more than express sympathy to these countries. In this connection Dr. Estanislao Zaballos, of Buenos Aires, has said:

"What other countries of America have the same world" problems as Panama or Mexico, the latter on the frontier of the United States and the former at the throat of the continent itself? They have nothing in common with the problems of the La Plata or the shores of Brazil or the coasts of Chile. The Monroe Doctrine is necessary today to the United States. The Caribbean washes the shores of the richest part of the United States and it is necessary that it be dominated by them in order to guarantee the independence and security of the United States."

The most important question concerning the Doctrine is whether it means that Europe must stay out of Hispanic American affairs and that the United States may go in, or simply that Europe shall stay out. It is difficult to see anything in the Monroe Doctrine to justify the assumption of an aggressive policy on the part of the United States toward Latin America. The original doctrine claims nothing for the United States that it does not concede to every other American nation. If in the Monroe Doctrine the United States arrogates to itself supremacy in the western hemisphere, it is only with respect to non-American powers, and with respect to them it wishes every American nation to be supreme. There is nothing in it that makes its provisions a monopoly by the United States. The proclamation of a similar doctrine by each of the other American nations would strengthen rather than impair the force of the Monroe declaration.

In his address at the unveiling of the Bolivar statue in New York President Harding clearly emphasized that the United States reserves no special privileges to itself under the Monroe Doctrine. Speaking to the entire Latin American diplomatic corps he said: 
"There have been times when the meatning of Monroeism was misunderstood by some, perverted by others and made the subject of distorting propaganda by those who saw in it an obstacle to the realization of their own ambitions. * * * They have falsely charged that we sought to hold the nations of the Old World at arm's length in order that we might monopolize the privilege of exploitation for ourselves. Others have protested that the Doctrine would never be enforced if to enforce it should involve us in actual hostilities.

"The history of the generations since that Doctrine was proclaimed has proved that we never intended it selfishly; that we had no dream of exploitation. On the other side, the history of the last decade certainly must have convinced all the world that we stand willing to fight, if necessary, to protect these continents, these sturdy young democracies, from oppression and tyranny."

Nevertheless the Monroe Doctrine has been a continual source of irritation to the Latin American nations. At first they accepted it gladly, as we have seen, as protecting them from Europe, but later we see it becoming in their eyes an instrument through which the United States presumed to dictate to them. "America for the Americans," they say, means "America for the North Americans."

In the early days no such talk was heard as this of Señor José de Astorga, writing in La Revista de América:

“*** The importance of securing concerted movement and unanimity of action among the countries of Latin America in order to offset the imperialistic ambitions of the United States is urgent and of extreme importance. The protests of con-fraternity, of disinterestedness and of respect for the political sovereignty and the commercial independence of Latin America which the Government of the United States sets forth so freely on every occasion, are not able to counteract or to lessen the eloquence of deeds, and these are the deeds: Tutelage over Cuba; the abduction of Panama; the embargo on the custom houses of Santo Do- 
mingo; economic and military intervention in Central America; the 'big stick,' 'dollar diplomacy' and the Lodge declaration."

The Latin Americans, however, are not alone in interpreting the Monroe Doctrine as meaning that the United States retains the right to control the western hemisphere. There are not a few North Americans who hold this view. These extracts from "America Among the Nations" by Prof. $\mathrm{H}$. H. Powers, are certainly disquieting:

"It is difficult to follow the expansion of America in the Caribbean without feeling that it will go farther. Whether it should go farther is not the question. This is neither an indictment nor a propaganda, but a study. No more is assumed than that national character shows a certain continuity, and that incentives which have been potent in the past are likely to be potent in the future. If so much be conceded, then the further development of Caribbean domination seems assured. If the considerations which have impelled us to restrict the liberty of Cuba, to take over the financial problems of Santo Domingo and to assume the management of Haiti, are legitimate, then there is more work of this kind for us to do. Conditions were no worse in Haiti than in other Caribbean countries. Utter recklessness and incompetency have characterized the management of every one of these pseudo-states, which the preoccupations of the real nations have temporarily abandoned to independence. It was a matter of chance which one of the dancers should first pay the piper, but all have danced and all must pay. As each faces in turn the inevitable crisis, the same problem presents itself. What reason is there to believe that we shall not meet it in the same way?"

"To the independence party Central America is its own little world. To the imperialistic party it is but a pawn on the mighty chessboard of world empire. We may sympathize with the one or the other but we must not judge the one by the standards of the other. The United States plays the vaster game, must play it and play it well, for the stake is its existence." 
"We have learned subtler ways of winning, more varied ways of ruling. We have found new reasons for old impulses, and old impulses have renewed their youth.

"Finally, we are'still confronted with opportunity. More than any other people we have prizes within our grasp. And we are grasping them. Never was our frontier more alive than it is today. Acquisition of new territory has become a commonplace and passes unnoticed. Not one American in a hundred realizes that we have a protectorate over Haiti and that our control is creeping out through all these southern seas. If he knew, his only reaction would probably be a slightly increased complacency. The door is thus opened wide for a government, embarrassed by the mischievous irresponsibility of these petty make-believe states, to take refuge in an ever-broadening imperialism. Unless the leopard changes his spots this must carry our frontier to the limits we have mentioned."

"Nor is the call of the tropics the only one. The war upon which we have now embarked has incalculable possibilities. We are committed not merely to the redressing of our grievances to date, but to the vastly larger program of settling such difficulties as the war itself may create. Without taking too seriously the fascinating program of. 'making the world. safe for democracy,' it is well to remember that the war is to be fought on European soil and in conjunction with nations having possessions in every part of the world. When the peace conference meets. we shall hear very little of the sonorous slogans which heralded the war's beginning and much of the concrete problems for which these phrases suggest no very tangible solution."

Such arguments as these certainly do not represent the best North American thought, yet they are common enough to spread wide alarm in Latin America.

Probably the most illuminating discussion of the present Latin American attitude toward the Monroe Doctrine was the debate in I9I4 in the columns of the Atlantic Monthly between Professor Hiram Bingham and Señor F. García Calderón. Professor Bingham's article was entitled "The Monroe Doctrine, an Obsolete Shibboleth." He argues for 
the abandonment of the Monroe Doctrine on the following grounds:

I. The Doctrine was proclaimed under a false conception of (a) geographical proximity, for the great conters of South American life are nearer to Europe than to the United States, and (b) the existence of natural sympathy, which is difficult to encounter in Latin America.

2. Latin America resents our attitude of being "practically sovereign on the continent" and opposed our war with Spain, our interference in Panama, Santo Dómingo, etc.

3. It places the United States in the false position of being the collector of Europe's debts, bringing our intervention in these states on many false grounds and thus multiplying the prejudice of Latin America against us.

4. The great growth of some of the South American states in recent years is ignored in the application of the Doctrine. As Viscount Bryce represents them as saying, "Since there are no longer rain clouds coming up from the East, why should our friend, however well-intentioned, insist on holding an umbrella over us?"

\section{Professor Bingham concludes:}

"Let us face clearly the fact that the maintenance of the Monroe Doctrine is going to cost the United States an immense amount of trouble, men and money. Carried out to its logical conclusion it means a policy of suzerainty and interference which will earn us the increased hatred of our neighbors, the dissatisfaction of Europe, the loss of commercial opportunity and the forfeit of time and attention which would better be given to settling our own difficult internal problems. The continuance of adherence to the Monroe Doctrine offers opportunity to scheming statesmen to diśtract public opinion from the necessity of concentrated attention at home by arousing mingled feelings of jingoism and self-importance in attempting to correct the errors of our neighbors."

Señor Calderón, whom readers of his "Latin America, Its 
Rise and Progress," would certainly not accuse of being partial to the United States, strongly maintained the usefulness of the Doctrine and its acceptability to Latin America if properly interpreted. He said:

"If the United States would affirm that it also is in accord with the sovereign republics of the south, that it respects the territorial status quo in this American continent which its own triumphant expansion seems to threaten, an American system of law would be established, and the union of the two races which govern this huge continent would become a political fact of most far-reaching consequence. We should be face to face, then, with a new Monroeism as the doctrine of American autonomy, accepted and proclaimed by all the peoples oversea, who would agree to protect one another against all future attempts at conquest, and then, in place of this vexing and harassing tutelage, we should have a sturdy declaration of American solidarity.

"Even by I9I I these generous plans showed signs of development. The United States, Brazil and Argentina, through friendly intervention, averted an imminent war between Peru and Ecuador. When they pacified Central America, Mexico came to their aid, and thenceforward their action no longer bore any resemblance to the intrusion of foreigners. It was in the name of a doctrine not only North American but Pan American that the peoples of the New World addressed the powerful nations which stood ready to tear them in pieces. No one then criticised this intervention of the great countries of the New World, of North Saxon and South Latin. The United States played its part alsowhich made its moral influence acceptable to the Spanish American nations.

"In principle the Monroe Doctrine is an essential article in the public code of the New World. Two newspapers of Buenos Aires, La Argentina and La Razon, have come to recognize it as such. (In them we read that the United States is the 'safeguard of American interests,' and they praise the North American republic for the paternal protection which it offers. It is only the brutal expression of the Doctrine, 
the cynical imperialism which is deduced from it, which becomes dangerous to the moral unity of the continent.

"The wisest statesmen have no thought of divorcing this doctrine from the future history of America, even when they criticise its excesses most severely.

"The men of the North have a civilizing function to fulfill in a continent wherein they exercise supreme power. If their behavior is disinterested, if they prevent war, if they fertilize these new countries abundantly with the gold of their banks, if they become apostles of peace and international justice, no one will ever forget the grandeur of their political rôle in the world's politics.

"In considering the behavior of the United States toward its neighbors, we must distinguish quite clearly between its attitude regarding Panama and its policy toward countries south of the Isthmus. Toward South America its intervention deserves only respect. The purely selfish interest of the United States evidently lay in the acceptance of war and anarchy, in accordance with the classical formula 'divide and rule'; yet the United States has kept the peace. From Panama to the La Plata it is working for the union of the peoples and for civilization.

"Here, then, is an aspect of the Monroe Doctrine of perpetual usefulness : the struggle against the wars which threaten to ruin the New World, still poor and thinly populatedintervention with the olive branch. In stimulating the union of South American republics the United States is at the same time protecting its own commercial interests, menaced by this perpetual turmoil. If its action were to halt there, if it renounced all territorial acquisition and set its face against all interference with the internal affairs of every state, the doctrine so often condemned would seem born anew and no one would dare to criticize its efficacy. Most of all, it is on the score of irregular political practices, of fomenting revolution, that the excessive tutelage of the United States comes in for most widespread condemnation. An Argentine writer, Manuel Ugarte, has summarized this sentiment in the phrase, "We wish to be brothers of the North Americans, not their slaves.' Even if this tutelage were designed to prepare democracies without democratic tradition for self- 
government after the Saxon method; even if, as in the case of Cuba, it is granted partial liberty and provisional privileges, the passionate feeling for independence which is so widespread throughout America would be exceedingly irritated by this rather contemptuous method of education. Great Britain pays more respect to the autonomy of her colonies than the new Saxon democracy is willing to bestow upon the still fragile independence of some American republics. What would be thought of the attitude of a Conservative minister of Great Britain who put a veto on the action of the Socialist government of Australia by dissolving the colonial Parliament and criticizing the laws of the free 'Commonwealth'? One cannot comprehend the policy which American peoples are often obliged to endure in their relations with Washington.

"In Latin America people do not understand the United States. A few offhand judgments often control the decision which leads Latin America to antagonism or to unreflecting infatuation. The Americans of the North are thought to be 'practical people.' Men say that they are intensely covetous of riches. They have no morality. The business man, always hard and arrogant in mind and brutal in method, is the symbol of the nation. Ideals, dreams, noble ambitions, never stir their breasts. These characteristics' of the North American the men of the South, according to their individual ideas, admire or despise.

"They forget how austere is the grandeur that Americans of the North acquire from their superb idealism, from their strong Puritan tradition, from the lust of gold made subservient to ambition for power and for influence over men. They are ignorant of the mysticism which forever flourishes in the United States, continually creating new sects, the perpetual Christian Renaissance whose energy was so greatly admired by William James. We must admit that in South American countries, with their narrow and superficial religiosity, we do not find this great concern regarding the line which divides the ideal from the fact. The example of the United States, the reading of its poets, the study of Emerson, the influence of its universities, an examination of the part which wealth has played in this de- 
mocracy, would, I conceive, go far toward reforming the bad manners of the South and make it appreciate the true fundamentals of the grandeur of North America.

"In my book on the Latin democracies I have set forth the contrasts which may easily be established between the Catholicism of the Spanish Americans, the state religion, uniform and formal, and the restless and active Protestantism of the United States; between the mixture of races in the South and that racial pride, 'the white man's burden,' which controls northern opinion. It would be very easy to push this analysis further and to set forth the strength of aristocratic prejudices among the Spaniards and the very democratic spirit which exists among the Saxons; to contrast the idealism of the North with the less vast, less generous ambition of the South; or the stanch, puritanical domestic life among the South Americans with a certain license of morals which exists in North America. But, in spite of this sharp contrast, there are resemblances not less evident than the divergent traits, an Americanism which gives a certain unity to the entire New World. All evidence points to the conclusion that if the United States acts in accord with Latin America, if the Monroe Doctrine loses its aggressive character, the influence of these twenty nations will be a force in the world's progress which cannot be despised."

That is the serious judgment of one of the great Latin American writers and diplomats, a man who becomes most indignant when he discusses North American imperialism.

CONFUSION OF THE MONROE DOCTRINE WITH OTHER POLICIES

With the passing of the years the Monroe Doctrine has been confused with at least three new ideas that have grown up during the period of our relations with the rest of the American continent. In the first place, we have confused it with the headship of the United States in America.]

The United States has developed a hundred times more rapidly than any other country in America, and as a nat- 
ural outgrowth of that development it has necessarily assumed the headship of the American nations. It is more or less the story of all history. The process is similar to that by which the Bishop of Rome became the Pope-the smaller bishoprics sent their problems to the great man in the city and thus his influence developed until he became supreme. In the same way the United States has grown very naturally into a position of leadership on the American continent. 'Whether we like it or whether Latin America likes it, there is no way of preventing the most advanced and most powerful nation in the group from exercising the greatest influence.]

This headship signified, among other things, that we must lead in the building of the Panama Canal, though of course it did not prescribe the method. It likewise meant that we must acquire naval stations and zones of influence for the protection of the Canal and all that that implies. But the Monroe Doctrine has nothing whatever to do with this.] These things came about from the position we necessarily assumed as the greatest nation on the continent. Perhaps - we did not have to do it in quite the way we did; better ways could have been found. Nevertheless the burden was laid upon us and we could not get away from it, so we took the lead just as other great nations have done in other parts of the world where their influence was dominant. Thus the various "Pan American Congresses" met. with little success until the greatest American nation entered and lent its overpowering influence to their promotion.

The second principle with which the Monroe Doctrine is confused is that of imperialism. Imperialism has nothing to do with the Monroe Doctrine, but is merely one of those tendencies of modern nations to take over smaller and more poorly organized countries.] We have been following other peoples in doing that, for the tendency is not only worldwide but is a factor in the economic as well as the political field today. [Most of our territory has really been gained at the expense of other nations. Let it be said to our credit, however, that, in contrast with most modern imperialistic nations, we bought most of the territory acquired. [This is our imperialistic policy, a thing apart from the Monroe Doc- 


\section{THE MONROE DOCTRINE AND LATIN AMERICA 173}

trine. Let us remind our Latin American friends that Chile, Brazil and Argentina have done like things. The big nations in South America have done as the big nation in North America. Of course it is easy to think the United States is the only sinner in the world, but every big nation is imperialistic. It is not the Monroe Doctrine that prompts us to do these things, it is the great and prepossessing idea of empire building. We are not nearly as guilty on this score as Great Britain.

The third point of confusion is with the idea of Pan Americanism. By Pan Americanism we understand the recognition of a community of interests among all American countries and a determination to work these out cooperatively to the best advantage of all concerned. The present tendency is to create a concert of American powers to act together for mutual protection and help, the maintenance of peace and the promotion of better commercial, political and intellectual relations. And this is not the Monroe Doc-, trine.

These three matters of headship, imperialism and Pan Americanism have all exerted an appreciable influence in our relations with Latin America, but they should not be confounded with Monroeism. We will clarify our action and our understanding of all inter-American relations as soon as we cease lumping everything related to Latin America under the one conception of Monroeism, which, after all, is to the average citizen of the United States largely a sentiment.

The address of President Wilson to the Mexican editors probably delighted Latin America more than any other official utterance with the exception of $\mathrm{Mr}$. Root's famous speech at Rio de Janeiro. Mr. Wilson said:

"The famous Monroe Doctrine was adopted without your consent, without the consent of any of the Central or South American states. If I may express it in the terms that we so often use in this country, we said, 'We are going to be your big brother whether you want us to be or not.' We did not ask whether it was agreeable to you that we should be your big brother. We said we were going to be. Now that 
was all very well so far as protecting you from aggression from the other side of the water was concerned, but there was nothing in it that protected you from aggression from us, and I have repeatedly seen the uneasy feeling on the part of representatives of the states of Central and South America that our self-appointed protection might be for our own benefit and our own interests and not for the interests of our neighbors. So I said, 'Very well, let us make some arrangement by which we will give bond. Let us have a common guarantee, that all of us will sign, of political independence and territorial integrity. Let us agree that if any one of us, the United States included, violates the political independence or the territorial integrity of any of the others, all the others will jump on her.'

\section{THE MONROE DOCTRINE AND THE LEAGUE OF NATIONS}

What effect has the World War, which has affected all international relations, had on the Monroe Doctrine? In answering this question one is again confronted with the basic question of the meaning of the Doctrine. President Wilson said, in addressing the Senate on June 22, I917, that "The nations should with one accord adopt the doctrine of President Monroe as the doctrine of the world." $\mathrm{He}$ explained that under this world doctrine no nation should seek to extend its policy over any other nation or people, but that every people should be left free to determine its own policy, its own way of development, unhindered, unthreatened, unafraid, the weak along with the great and powerful.

President Wilson's understanding of the Monroe Doctrine is here clearly revealed. It is certainly not the same as Professor Bingham had when he advocated its abandonment because it kept us from being well regarded in Hispanic America. The simple Monroe and Wilson insistence that each nation shall have the right to develop along its own lines, without interference from the outside, that "good faith and justice toward all nations" shall prevail, represents an entirely different conception. [While Monroe's proposal was that no European nation should seek to extend its authority over an American nation, Wilson proposed that no 
nation in any part of the world should seek to extend its polity over any other nation or people.

[This interpretation of the Doctrine was the one given it by President Cleveland in dealing with the Venezuelan boundary dispute, when he said that the Doctrine found its basis "in the theory that every nation shall have its rights protected and its just clcims enforced." At the same time Secretary Olney pointed out to Great Britain that "the people of the United States had a vital interest in the cause of self-governmer" "and that the British attitude toward Venezuela so threatened the American policy that if the power of the United States was adequate to prevent the carrying out of British purposes it would be done.

It is natural that this Doctrine, maintained for a century and resulting in giving weaker nations in America a chance to develop without outside interference, should be of value in developing a world policy that would protect small nations. That the efficacy of the Monroe Doctrine has depended on the force the United States could bring to its support, suggests of course the need of force to support any world application of the same principle-the principle which has been recognized in the formation of the League of Nations.

Just as the Latin American peoples had favored the original Monroe Doctrine and appreciated its protection from Europe, so they immediately welcomed the extension of the Doctrine to the whole world as embodied in the League of Nations. For strangely enough our southern neighbors, believing that the United States has shifted from the original purpose of the Doctrine and is now using it merely for its own selfish purposes, saw in the proposal to bring the world into the agreement a guarantee that Hispanic America would not only be protected from Europe but from the United States itself.

The League of Nations was received with the greatest enthusiasm by all the southern countries. Here was the movement that would get the American nations beyond the impasse which had been reached in the much talked-of Pan Americanism. For, on the one hand the United States could not give up the historic Monroe Doctrine and on the 
other the Hispanic Americans could never come into free relations with their northern neighbor if that Doctrine meant, as it seemed to have come to mean, the hegemony of the United States in the Pan American family.

But here was the way out of the dilemma-make the Doctrine world wide. The United States would surrender nothing of her historic insistence that European nations must not project themselves into American life, and Latin America would have her fears and her implied inferiority removed, since the United States would thus assume the same obligation to respect the independence of the small American states as did all other nations. Thus the greatest difficulty in the way of continental solidarity would disappear without embarrassment to any of the parties.

This feeling was well expressed by the Cuban, Orestes Ferrara, in his review, La Reforma Social, as follows:

"When Mr. Wilson and Mr. Taft refer to the declarations of President Monroe and insist that the detachment of American nations will not receive a blow but on the contrary will be more absolute because the Doctrine is universally accepted by the establishment of the League, they say something that reveals very clearly how their minds turn to the past when the principle of the independence of American nations was threatened by the transference of the consequences of another great European conflict to American soil. Evidently Wilson and Taft regard the Monroe Doctrine in its original sense, the most just to other rights. It is not so with Senators Knox and Lodge. They think of the Doctrine as it has been practised for the last twenty-five years, which seems to have justified the relations with Panama, Nicaragua, Santo Domingo, Haiti, etc., and which has established the absolute dominion of the United States over the Americas. The difference is therefore paramount, being on the one hand a principle and on the other a selfish interest.

"The truth is that there has never been a declaration in the international life of the world with purer ideas and more noble purposes than the Monroe Doctrine. The North American statesmen of that time had the most unselfish ideas about it. Jefferson, from his retirement, gave to it 
the whole endorsement of his serene mind and tranquil soul. But in the course of time the formula 'The United States standing before Europe in defense of the Americas' naturally brought the predominance of the United States in America. And if the United States had not practised in her international relations the Anglo-Saxon principle that the rights of others shall not be interfered with unless one's own interests are clearly threatened, a situation of this kind would have been fatal to the rest of America.

"To be more specific, we may affirm that if any other nation than the United States had had her hands free in America as she has, with power to make or unmake the map south of the Rio Grande and even to do so with the blessings of Europe, the rights of Latin America would have suffered profoundly.

"But this relative prudence has not vitiated the change of form of the Monroe Doctrine which makes it not the old powerful and unilateral declaration of the early days, but a real program of action which permitted the Presidents of the United States to dictate rules for American international - politics and even national political rules to apply to other countries. Thus the Caribbean has come to be considered as a mare nostrum. The United States has come to regard the Monroe Doctrine, thus transformed, as backing those other policies-trade follows the flag and dollar diplomacy.

"Thus Wilson and Taft on the one hand and Lodge and Knox on the other, since they speak of different periods of the Monroe Doctrine, are both right when one maintains that the League of Nations will maintain the Doctrine intact and the others contend that the opposite is true.

"Discussing the question of the League, if the United States, having helped to break the balance of power in Europe by defeating Germany, should remain outside the alliance of the victorious nations, her isolation will not mean her strength but her weakness. The obligations of the Monroe Doctrine would not then be carried against a divided Europe, but before an alliance of states victorious on sea and land. It is not easy to prophesy the difficulties of the future, but it can be seen that the mission assumed by the United States will be full of difficulties, as it has in the past. 
To share jointly these responsibilities would mean the obviating of conflicts or diminishing the possibility of conflicts which may take place not in Europe but in the tranquil Americas.

"On abandoning the rights of exclusive protection, she would be free of multiplied responsibilities and know that if a conflict occurred, it would be concerning matters that affected her directly and not remotely. The principles of Washington and Monroe would have passed through a complete evolution and become the admitted principles of all humanity, not simply the canons of American law.

"The Monroe Doctrine could thus become the doctrine of the world. Only the aspirations of conquest which make of the doctrine of defense of the small nations of this continent an excuse for continual aggression approaching an American Prussianism, will have died forever."

But this wise and just solution of the Pan American impasse was not to be. A group of North Americans who appreciated the necessity of protecting their own prerogatives but not those of any other nations, insisted on the covenant of the League making specific acknowledgment that, while all the nations of the world would surrender all special privileges and rights of interference with their neighbors, the United States must still have the special privilege of determining the course of national development in the western hemisphere. So the following was inserted as Article XXI of the covenant:

"Nothing in this covenant shall be deemed to affect the validity of international engagements such as treaties of arbitration or regional understandings like the Monroe Doctrine, for securing the maintenance of peace."]

If this article had gone further and defined the Monroe Doctrine as not giving the United States any special privileges on the American continent, but rneaning, as President Wilson had intimated, that every people should be left free to determine its own policy, there could have been no objection. But this was not done. And so at one stroke the old 
situation was continued and made worse. For it looked as if this was a move to have the whole world agree to leave with the United States the determination of all American questions. And, of course, if the Latin American nations signed the covenant, they themselves became guarantors of an arrangement which those who insisted on the inclusion of this reservation stated to mean that the United States would have the right to interfere in the national life of the other American nations whenever it deemed such a course expedient.

Here was Latin America's dilemma: If she stayed out of the League she lost the opportunity of being linked up with the only organization that offered to help the small nation. If she went in she signed a document which might mean her agreement to complete domination by her great northern neighbor. She was much in the position of a man who is forced to borrow a certain sum of money to escape ruin, but who is asked to sign a note for an unknown amount in order to get the money. It leaves him in doubt as to whether he is to be ruined now or later.

\section{FURTHER DEFINITION DESIRABLE}

This was what led little El Salvador to direct a note to our Department of State asking . for a definition of the Monroe Doctrine. This note, in the first place, recites that despite its neutrality in the war, El Salvador manifested "its sympathy on every occasion for the ideals which animated the Government of the United States in entering the war," praises President Wilson for "having crystallized the legitimate hopes of a fruitful peace by submitting the draft of a League of Nations covenant," says El Salvador, "manifests the desire to adhere to this treaty which sanctions arbitration as the only method of settling disputes between nations," and continues:

"The whole text of the treaty is both suggestive and attractive. In it there is a return to those principles of life long awaited by sociologists and publicists. And indeed it seems as if from the ruins of war there have arisen with 
greater strength and potency the beautiful gospels which in a moment of folly were relegated to the discard by those who through the immutable laws of international interdependence were especially charged with sustaining and upholding them.

"The text of the treaty contains, however, one article which has awakened warm discussions throughout the whole American continent including the United States, due no doubt to its brevity and lack of clearness. I refer to Article XXI, drafted, in the following terms: 'Nothing in this covenant shall be deemed to affect the validity of international engagements, such as treaties of arbitration or regional understandings like the Monroe Doctrine, for securing the maintenance of peace.'

"The legal scope of this provision from an international viewpoint is open to differing interpretations, since in the vast scheme of the League of Nations treaties of arbitration and regional understandings, such as the Monroe Doctrine, are recognized and sanctioned, despite the fact that as to the highly peaceful purpose of the latter doctrine there does not exist harmonious meeting of minds nor an absolute criterion.

"From the year I823, in which the distinguished James Monroe rejected all intervention by European nations in the affairs of the American continent to the present day, this doctrine has undergone different applications depending upon the diverse political tendencies prevailing at that particular time in the United States.

"It would be unnecessary, Mr. Secretary, to undertake any detailed exposition of the various views of prominent thinkers and public men of the United States as to the genuine and correct interpretation of the Monroe Doctrine, which former Secretary of State Elihu Root regarded as 'a declaration based on the right of the people of the United States to protect itself as a nation, and which could not be transformed into a declaration, joint or common, to all the nations of America or even to a limited number of them.'

"My Government recognizes that the Monroe Doctrine consolidated the independence of the Continental States of Latin America, and saved them from the great danger of a European intervention. It realizes that it is a powerful fac- 
tor in the existence of the democratic form of government on this continent and that it raises a barrier to European colonization.

"Since, however, the covenant of the League of Nations does not set forth nor determine the purposes nor fix a definite criterion of international relationship in America, and since, on the other hand, the Doctrine will be forthwith transformed-in view of the full sanction of the nations of the world-into a principle of universal public law, juris et de jure, I request that your Excellency will be good enough to give the authentic interpretation of the Monroe Doctrine as it is understood in the present historical moment and in its future application by the Government of the United States, which must realize that my Government is keenly desirous of securing a statement which shall put an end to the divergence of views now prevailing on the subject, which it is recognized by all is not the most propitious in stimulating the ideals of true Pan Americanism.

"Contrary to the authorized and respected view of former Secretary of State Root, the Monroe Doctrine through its inclusion in the covenant of the League of Nations will be converted without doubt into a genesis of American international law.

"Since any amendment to the text of the treaty and even the rejection of all of its provisions by the American Senate would still leave intact the various points which this international agreement covers as to the other signatory nations, by virtue of their general and expressed acceptance, the principle embraced in the League of Nations, and therefore the Monroe Doctrine, would be virtually accepted as a fundamental principle of public American law by all those countries that signed or manifested their adherence to the Peace Treaty.

"The necessity of an interpretation of the genesis and scope of the Monroe Doctrine not only in the development of the lofty purpose of Pan Americanism, but in order that that Doctrine may maintain its original purity and prestige, is rendered all the more urgent."

Even before El Salvador had written her now famous note 
to the Department of State, ex-President Bonilla of Honduras, who represented his country at the Peace Conference, presented to that body the following communication:

"In this covenant all peoples represented in this Conference are directly interested; the smaller nations, like that which I represent, more if possible than the greater ones. Its bases, as expressed by the Commission, are not known; but the public press has asserted that amendments have been proposed: among these a proposal by the delegation of North America to declare that 'the pact shall not affect the validity of other international conventions such as the arbitration treaties or regional understandings, like the Monroe Doctrine, to ass'ure the maintenance of peace.'

"The Monroe Doctrine affects the Latin American republics directly. As it has never been written into an international document, nor been expressly accepted by the nations of the Old Continent, nor of the New World; and as it has been defined and applied in different manners by presidents and other statesmen of the United States of America, I believe that it is necessary that in the pact about to be subscribed it should be defined with entire clearness, in such way that it may be incorporated in the written international law.

"The North American delegation is presided over by the Honorable Woodrow Wilson, and it is certain that if the Monroe Doctrine was not defined the delegation had in mind the definition or interpretation that Mr. Wilson, as President of the United States, has given to it in his various addresses from that which he voiced at Mobile in I9I 3 to the last in the current year. In these he declared that the Doctrine is not a menace, but is a guaranty for the feeblest of the nations of America; and he repudiated expressly the interpretations that had been made to signify that the United States had a right to exercise a kind of tutelage over the other republics of America.

"Especially in his discourse with the Mexican journalists on June 7, 1919, he declared that the guaranty that this Doctrine implied in favor of the feeble countries is not with relation to the powers of the Old World only, but relates to 
the United States also; and that he spoke of the celebration of a Pan American pact that might be realized and might include this point. Such declarations have made President Wilson the best of the exponents of the ideals of the peoples of Latin America.

"All these facts induce me to present the accompanying proposition, which I hope will merit a favorable reception by the delegation of the United States, and will be supported by the Latin American republics, which with it will pay their tribute of admiration and respect to the First Magistrate of the North American republic, that has given such proofs of its love of justice.

"If the American amendment to which I referred is phrased in the terms published, or in others like them, the pact of the League of Nations will be no obstacle to a union or confederation of other form, by the peoples of Latin America, that will tend to a realization of the dream of the immortal Bolivar."

The clause which Dr. Bonilla offered as an addition to the proposed compact of the League of Nations may be translated as follows:

"This Doctrine, that the United States of America have maintained since the year 1823 , when it was proclaimed by President Monroe, signifies that: All the republics of America have a right to independent existence: that no nation may acquire by conquest any part of the territory of any of these nations, nor interfere with its internal government or administration, nor do any other act to impair its autonomy or to wound its national dignity. It is not to hinder the 'Latin' American countries from confederating or in other forms uniting themselves, seeking the best way to realize their destiny."

The view taken generally in Latin America of the Salvadorean note is well illustrated by the following editorial utterance of El Universal, of Mexico City:

"We published yesterdày the Note addressed by the repub- 
lic of El Salvador to the Secretary of State of the North American Union asking for an exact interpretation of the 2 Ist article of the protocol of the League of Nations, referring to the recognition of the Monroe Doctrine by the Latin American nations. It is a document of far-reaching importance.

"On the appearance in 1823 of the Monroe Doctrine, it had the character, as has been expressed by the eminent Chilean statesman, Don Alejandro Alvarez, of a sort of gospel of the New World. President Monroe, according to Alvarez, though taking his stand exclusively on the interests of his own country, in his famous message to Congress, summarized and expressed admirably and clearly the political situation and aspirations of the whole New World. [Circumstances then obtaining in Europe made some such declaration urgent. There was a controversy on between Russia and England over the boundaries of their possessions in America; and besides-and graver still-the countries signatory to the Holy Alliance were suspected of the purpose of coming to the help of Spain for reconquering her lost American colonies. When, therefore, the United States proclaimed its affirmation that the New World ought to be governed by republican organizations, and that all the countries on this side are free and equal, as relates to Europe, the independence of the budding republics was assured -an attitude on the part of the Northern Republic which cannot fail to meet with the goodwill of the other countries.

"Up to that point, and for the reasons set forth, the Monroe Doctrine could not be considered a particular expression of the sentiments of the United States; it was rather the crystallization in international relations of the aspirations of all America. But since then, as the various countries of the continent have gone forward in their evolution, the Latin republics have not always moved harmoniously with the United States-nor even with one another. Thus it has come about that while some publicists consider the Monroe Doctrine as a sort of tacit agreement among all the American nations for warding off the occupation of territory by Europe, or its active intervention in American affairs, there 
are others who have come to believe that the only thing the United States had in view in promulgating the Doctrine was to substitute their own intervention for that of Europe in the affairs of the other nations of this continent, and, in that connection, it has not yet been settled whether acts of imperialism, deliberately engaged in by the United States against the sovereignty of Latin American republics, are or are not subject to regulation by the Monroe Doctrine.

["It is a state of things which has resulted in many misunderstandings. We do not know, really, what to think; as, in view of diverse and even contrary interpretations by different statesmen, the Monroe Doctrine or 'Monroeism' has become something extremely foggy and obscure. It is to this fact that is due the lack of confidence in it on the part of the Latin republics; to this, and to nothing else, was due the statement on the part of our Government recently that it did not recognize that Doctrine.

"President Wilson himself seemed to justify that want of confidence when he suggested in his address to the Mexican editors in June, 1919, that all the Latin American countries should undertake a revision of that Doctrine and should come to an agreement that would put the question of their independence outside the danger of any imperialistic encroachment. If thus the very author of the League of $\mathrm{Na}$ tions admitted less than a year before that it was only natural that the Monroe Doctrine should inspire in Latin America some want of confidence as not being a real community pact, how can those nations which have not yet been called into the consultation adhere to the League of Nations, in which the Monroe Doctrine is explicitly recognized?

"As we see the matter, El Salvador has put a finger on the sore spot, as the saying goes, in this most complicated matter of American politics. Will its note bring about a general revision, a Pan American revision such as Wilson intimated of the Monroe Doctrine? Unless some such thing happens, we do not see how the Latin American nations can sign a compact, such as that of the League of Nations, unless some light can be thrown on a matter that so proioundly concerns their interests."] 
The framing of a reply to E1 Salvador taxed the ingenuity of our Department of State. But a way out was happily found by a simple citation of the address of President Wilson before the Second Pan American Scientific Congress, where the President had discussed the Moproe Doctrine as follows :

"The Monroe Doctrine was proclaimed by the United States on her own authority. It has always been maintained, and always will be maintained, upon her own responsibility. But the Monroe Doctrine demanded merely that European governments should not attempt to extend their political systems to this side of the Atlantic. It did not disclose the use which the United States intended to make of her power on this side of the Atlantic. It was a hand held up in warning, but there was no promise in it of what America was going to do with the implied and partial protectorate which she apparently was trying to set up on this side of the water, and I believe you will sustain me in the statement that it has been fears and suspicions on this score which have hitherto prevented the greater intimacy and confidence and trust between the Americas. The states of America have not been certain what the United States would do with her power. That doubt must be removed. $]$.And latterly there has been a very frank interchange of views between the authorities in Washington and those who represented the other states of this hemisphere, an interchange of views charming and hopeful, because based upon an increasingly sure appreciation of the spirit in which they were undertaken. These gentlemen have seen that, Lif America is to come into her own, into her legitimate own, in a world of peace and order, she must establish the foundations of amity, so that no one will hereafter doubt them.]

"I hope and believe that this can be accomplished. These conferences have enabled me to foresee how it will be accomplished. [It will be accomplished, in the first place, by the states of America uniting in guaranteeing to each other absolute political independence and territorial integrity. In the second place, and as a necessary corollary to that, guaranteeing the agreement to settle all pending boundary disputes as 
soon as possible and by amicable process; by agreeing that all disputes among themselves, should they unhappily arise, will be handled by patient, impartial investigation and settled by arbitration; and the agreement necessary to the peace of the Americas, that no state of either continent will permit revolutionary expeditions against another state to be hitted out on its territory, and that they will prohibit the exportations of munitions of war for the purpose of supplyinga
revolutionists against neighboring governments."

This reply was received by El Salvador with diplomatic expressions of appreciation, but her leaders, as well as those of other Latin American countries, recognize that the sentiments expressed by one of our presidents before a scientific gathering cannot be considered as an authoritative and binding definition of any fundamental policy like the Monroe Doctrine. They want rather a declaration in which the executive and legislative branches of the Government, after a discussion which allowed public opinion to express itself, would officially state the position of the nation.

The following words of Señor A. de Manos-Albas, written a few years ago in the English Revicz' of Reriez's, still remain true:

"The means to accomplish unity of sentiment and to dispel the misgivings between the United States and Latin America is not far to seek. It is only required to amplify the Monroe Doctrine to the full extent of its logical development. *** If the United States should declare that the era of conquest on the American continent has been closed to all and forever, beginning with themselves, the brooding storm of distrust will disappear from the Latin American mind, and an international cordiality of incalculable possibilities will ensue, not only for the welfare of the American nations, but universally for the cause of freedom and democracy."

EAt this writing the United States is in a most peculiar position. Having insisted upon inserting the Monroe Doctrine clause into the Covenant, a clause in which no other nation in the world was interested and to which many were 
opposed, the United States finds itself the only nation of consequence out of the League. The Latin American countries were so enthusiastic for the League idea that fourteen out of twenty of them signed, with the Monroe Doctrine clause and all, almost without debate. The United States was expected to join as well. Most of these countries followed the United States into the war and they all thought they were going with her into the League. Now they are awakening to the fact that their supposed leader is not with them, and the situation is a bit disconcerting to some of them.

The situation reminds one of an incident in the French Revolution when a group of politicians sat discussing matters of state when a great mob rushed by the building. One of the group jumped to his feet, ran to the door and exclaimed, "There go my people. I must hurry and follow them, for I am their leader!"

The complaisant North American may smile at the mention of the possibility of our losing our position of dominance on this continent, but the present situation at least suggests the development of a condition which will unite the rest of America with Europe rather than with us. It is easy to note that among Latin Americans there is great confusion over the situation, and some frankly say that the present division may mean a final separation of the Latin American countries from North America. Commenting on the presidential election in the United States, La Nación, of Buenos Aires, a paper which all during the war ardently supported the United States, said:

"Confronted with the dilemma of abandoning either the League of Nations or the Monroe Doctrine, the Latin American countries probably would choose to abandon the latter. Many people in the United States have believed that the various South American countries, members of the League, would withdraw in order to follow the policy inspired by the United States, and contrary, naturally, to the League. $* * *$

"The declaration on the Monroe Doctrine Senator Harding made to the correspondent of La Nación hardly seems an 
adequate cause for the South American members of the League to abandon it. In effect Senator Harding told our correspondent that the Monroe Doctrine was not an international pact or agreement but a declaration of policy by the United States which promised protection against abuses or aggressions by European nations, precisely an interpretation which causes the greatest resistance from most, if not all, of these countries, and which is contrary to the interpretation President Wilson has given, according to which the Doctrine established among the American nations a most perfect equality - an equality that cannot exist if the question of protection that is not asked is the product entirely of the one-sided resolution of a power declaring itself the protector against dangers in which no one believes."

[If the United States does not form part of the League, these southern countries will find themselves in a different camp from the United States, having acquired a special status in relation to other members of the League, and will be forced to consider the United States as a factor to some extent foreign to the development of their peaceful policy. This surely will not be satisfactory either to them or to us, in view of the sincere desire of both parties that an accord shall exist between the two sections of the continent.

This reported interview with President Harding raises an important question concerning the Monroe Doctrine about which there is absolute difference of opinion. The President is reported as intimating that the Doctrine is not to be considered as an international agreement, but solely as a declaration of the United States, maintained by the power of the United States. Secretary Root, already quoted, also said that it could under no circumstances become a joint agreement.

But President Roosevelt said, in an address at Rio de Janeiro:

"All the nations which are sufficiently advanced, such as 3razil and the United States, should participate on an absolute equality in the responsibilities and development of this loctrine so far as the interests of the western hemisphere 
as a whole are concerned. It must be made a continental and not a unilateral doctrine. **** If ever, as regards any country, intervention does unfortunately become necessary, I hope that wherever possible it will be a joint intervention by such powers as Brazil and the United States, without the thought of self-aggrandizement by any of them, and for the common good of the western world."

As has already been shown, President Wilson accepted the same idea of the Monroe Doctrine being extendable not only to all America but to the whole world. In this same spirit were his words in addressing Congress December 7, I9I5, when he said:

"There was a time in the early days of our great nation and of the republics fighting their way to independence in Central and South America, when the government of the United States looked upon itself as in some sort the guardian of the republics to the south of her as against any encroachments or efforts at political control from the other side of the water; felt it its duty to play the part even without invitation from them; and I think that we can claim that the task was undertaken with a true and disinterested enthusiasm for the freedom of the Americas and the unmolested self-government of her independent peoples. But it was always difficult to maintain such a rôle without offense to the pride of the peoples whose freedom of action we sought to protect, and without provoking serious misconceptions of our motives, and every thoughtful man of affairs must welcome the altered circumstances of the new day in whose light we now stand, when there is no claim of guardianship or thought of wards but, instead, a full and honorable association as of partners between ourselves and our neighbors, in the interest of all America, north and south."

It is this spirit faithfully carried out that will make all Latin America join with us in the support of the Monroe Doctrine and be at one with us in building a continental 
solidarity. The following comment by La Prensa, of Buenos Aires, on this message is expressive of the way all Hispanic America responds to such sentiment:

"There has been a gradual and continuous change in the American policy toward the republics of this continent. These changes have been coincident with the visits of prominent Americans to South America, with the result that a better knowledge of the state of civilization which has been reached by South Americans has become more general. This has been the principal cause of the gradual transformation. The Monroe Doctrine is now essentially modified. It is necessary that it should no longer have the character of tutelage that it had at the time of its origin, but it must undergo an evolution toward Pan Americanish.

"No higher, more fundamental, more authoritative utterance has been made on the subject than that embodied in President Wilson's message. President Wilson made his statement without reserve and with sincerity, showing that it was the result of serene reflection. According to President Wilson, Monroeism will be a means of defense of this continent, but all the American states will be members of the international community, the United States having the same sovereign rank as the others.

"President Wilson's message will be as transcendent as was President Monroe's, both being in accord with regard to solidarity, but differing in regard to the conception of circumstances. President Wilson's program does not lack anything necessary to the high development of ideals."

Let all America then unite in supporting the Monroe Doctrine, and when all have gone into a World League of $\mathrm{Na}$ tions, let a subdivision of that League act as the American League, suggested by Bolivar in 1826 and by Wilson and Brum in 1917 , to promote peace and mutual prosperity among all American nations.

Dr. Baltasar Brum, President of Uruguay, in an address before the university students of the capital of his country, advocated this League of American Nations in the following important declarations: 
"Owing to the state in which European countries remain after the struggle, it may be said that fear of invasion by them in America has been removed for many years. But is that sufficient reason for us to take no interest in the future and turn away from the Monroe Doctrine with the pretext that it is now unnecessary? I believe that today, more than ever, we should use foresight in searching for formulas that may assure forever the peace and full independence of American countries.

"The principle of American solidarity, based on the constitution of a continental league, is more ample than the Monroe Doctrine, because it will not only defend the countries of America against foreign invaders but also against imperialistic tendencies which might arise among themselves.

"The formation of this League, in my opinion, would be a logical consequence of the Treaty of Versailles, which, in recognizing and expressly accepting the Monroe Doctrine, seems to be desirous of limiting its field of action, so far as American affairs are concerned. On the other hand, the Supreme Council of the League of Nations is composed principally of the delegates of the Great Powers, nearly all the American countries having been excluded. These countries need, therefore, to create a powerful organization to look after their interests in the decisions arrived at by the League of Nations. Harmonious and joint action by the 'American League' would avoid European intervention in our affairs."

Some have objected to this League of American Nations because they fear it would become a rival to the World League. But there seems to be no reason why such a League would not really strengthen the World League by assuring its unanimous support by all American nations. These nations would naturally discuss beforehand the questions to come before the League and decide upon the attitude of all the American nations. Indeed it could easily and profitably develop into a kind of sub-committee of the committee of the whole, to consider purely American matters. By such a relationship the American nations could settle their own 
questions, but with the double advantage that these smaller nations would have some final appeal in case of absolute injustice by the one American power that is easily able to impose its will on all the rest of the continent ; also the transAtlantic nations would be enabled to have direct touch with the American nations in working toward the peace and prosperity of the world at large.

We are today in the midst of one of those great world epochs when all relations with and inheritances from the past are in flux. The best of the past must be readjusted, reformed, redefined to contribute to the future-the new day, which, whether we like it or not, is different from the old.

The Monroe Doctrine has been the greatest influence on the American continent for preserving the republican form of government.] It is today neither an "obsolete shibboleth" nor an "international impertinence," if understood in the original and true sense. [There is no question that the Doctrine has been made to cover a multitude of sins, political and commercial, and is abused by North American jingoes. The wrong appeal to and interpretation of the Doctrine has developed among the Hispanic American peoples a prejudice against it, and among the statesmen of the South an insistent demand for a definition of its present application. If we can be big enough to put ourselves in the place of our southern neighbors we must acknowledge that they have a right to a clear understanding of how far the Doctrine means "America for the Americans" and how far it means "America for the North Americans." If we are to retain our leadership in America and in the world in this new age when the rights of the small nation and the common man are the concern of all, and when a righteous peace in the world is tine pearl of great price for which all else may be sacrificed, we will turn toward world friendship rather than shrivel into a Prussian nationalism.

And if we are honest, as we believe we are, in our contention that, as Secretary Root said, "We wish for no victories but those of peace, for no territory except our own," and as Roosevelt said, "This Doctrine has nothing to do with the commercial relations of any American powers save 
that it in truth allows each of them to form such as it desires," and, as President Wilson said, "Let us have a common guarantee that all of us will sign, an agreement of political independence and territorial integrity," -if we really mean these things, let us make them so clear] and so authoritative that our worst enemies cannot but admit that our relations with Latin America are guided, as John Hay said they were with China, by the open door and the Golden Rule, and that the Monroe Doctrine is the simple expression of our commitment to the principles of American democracy, developed without outside interference, and of our willingness to give the last drop of our blood for its defense.]

\section{Sources of Further Information on the Monroe Doctrine and Latin America}

Articles on Present Status of Monroe Doctrine, Annals of American Academy of Political and Social Sciences, I9r4.

Atlantic Monthly: Discussion between Hiram Bingham and $F$. García Calderón, I9I4.

Bigelow: The American Policy.

Brum, Baltasar: Solidaridad Americana.

Calderón, F. García: Latin America, Its Rise and Progress.

Hart, Albert Bushnell: Monroe Doctrine, An Interpretation.

Leuchsenring, Emelio Roig DE: La Doctrina de Monroe y el

Pacto de la Liga de las Naciones, Cuba Contemporanea, 1920. Lово, Helio: Causas Diplomaticas.

Moore, J. B.: American Diplomacy, Chapter VI.

Pereyra, Carlos: El Mito de Monroe.

Powers, H. H.: America Among the Nations.

Proceedings of the American Society of International Law, 1914. Quesada, ERnesto: La Doctrina Monroe, Su Evolución Histórica. Richardson, James Daniel: A Compilation of the Messages and Papers of the Presidents.

Shepherd, William R.: New Light on the Monroe Doctrine, Political Science Quarterly, 1916.

Sherrill, C. H.: Modernizing the Monroe Doctrine.

Wilson, George Grafton: The Monroe Doctrine After the War. Zeballos, E. S.: La República Argentina en la Liga de Naciones (Reprint of Editorials in La Prensa). 


\section{Chapter VI}

\section{PAN AMERICAN CONFERENCES}

The movement for American unity may be divided into two periods. The first period embraces the first two-thirds of the nineteenth century, during which the movement was led by Hispanic America, especially by Colombia and Peru, fostered also by Mexico, Central America and Venezuela. The idea generally revolved around a plan for a congress, with more or less power, which should meet at regular periods. The emphasis was placed on unity among the Spanish-American countries, the United States and Brazil sometimes being included and sometimes left out.

We have considered the first of these periods and noted that "the spirit was willing"-nay, anxious- "but the flesh was weak." The failure of the second Panama Congress called by Colombia in 1881 seemed to finally convince even the most utopian of the Spanish-Americans that they had too many problems in their own separate countries to actually get together. They were ready therefore to try some other way. Everything pointed to the new way consisting in new leadership and in working toward a less rigid unity with a freer course for each separate country. So the second period set in under the leadership of the United States and the loosely organized Pan American Congresses, the first of which met in Washington in 1889 and the last one in Buenos Aires in 1910.

The Civil War in the United States brought about in this country a decided change toward Hispanic America. The bravado of Manifest Destiny and the depreciation of the southern republics because of their frequent internal troubles was greatly reduced by our own sad experience which almost disrupted our nation and left us considerably humbled. Lincoln, in direct contrast to the bluster of Polk and Pierce, 
sent a minister to the Mexican government with instructions to show an attitude of cordiality, frankness, friendship and even magnanimity. Napoleon was informed that he must get his troops out of Mexico, and Juarez was thus enabled to win his fight against a foreign invader, who had all but destroyed Mexican sovereignty. As the United States recovered a bit more from her awful struggle and lifted her eyes a little beyond Mexico, she found a bad situation in South America, which offered another opportunity to show this new sympathy. For five years a state of war had existed between Spain on the one hand and Chile, Peru, Ecuador and Bolivia on the other. While the exhausted state of the United States Government did not seem to make it wise to invoke the Monroe Doctrine and make peremptory demands on Spain, Secretary of State Hamilton Fish did bring about a conference at Washington in 1870 , at which a "perpetual armistice" was signed.

\section{THE FIRST PAN AMERICAN CONFERENCE}

The attention of the United States was again turned to South America by the War of the Pacific, with Chile on one side and Peru and Bolivia on the other, which continued from 1879 to $188 \mathrm{I}$. In the latter year James G. Blaine became Secretary of State. He held to the same ideas of American Unity advocated by his distinguished predecessor, Henry Clay. Such a statesman had no trouble in realizing that the time had arrived for the United States to take the lead in the movement for continental solidarity. On November 29, I88I, the Secretary of State issued in the name of the President an invitation to all the American independent nations to take part in a conference "for the purpose of considering and discussing the methods of preventing war between the nations of America."

Because of the continuance of the War of the Pacific, it was not possible for the Congress to be held at the date set. But the idea persisted. In I 888, largely through the efforts of James G. Blaine, who had again become Secretary of State, the first Pan American Conference was called under Act of Congress (May 24, 1888), to meet in Washington. 
The first session was held on October 2, i 889. All the independent American states were represented. The conference continued until April I9, I890.

The commercial aspect of Pan American relations had been first cliscussed in the United States Congress in I884, when an act was passed creating a commission of three to make a careful study of commercial relations between the different American republics; and Secretary Frelinghuysen advocated a policy of reciprocity treaties with the Latin American countries. Added to the commercial motives were those of a desire for peace among the American countries, as already pointed out. The following words, appearing in Secretary Blaine's call, show his carefulness not to offend any or to assume any attitude of superiority:

"The delegates will be able to show to the world an honorable, pacific Conference of eighteen independent American states where all are united in terms of absolute equality; a Conference in which there will be no effort to coerce any delegate against his own conception of the interests of his nation; a Conference that will not permit secret machinations concerning any question, but will frankly give to the world all its conclusions; a Conference that will not tolerate any spirit of conquest, but that will cultivate an American sympathy as vast as the continent; a Conference that will not form selfish alliances against the old nations of which we are proud to call ourselves descendants; a Conference, finally, that will not look for anything, nor tolerate anything that is not according to the general sentiment of the delegates, opportune, prudent and pacific."

That Secretary Blaine had not misjudged the opportuneness of the United States taking the lead in the movement of American Congresses is indicated by the replies received from the invitation for a Pan American Congress to meet in Washington. Several of the South American states expressed very deep appreciation of this step taken by the United States to bring America closer together.

Venezuela replied: "The future of South America may be considered as secure under the guardianship of the great 
republic which is both our teacher and our model." Guatemala adhered to the probability that "under the auspices and by the initiative of such a powerful and marvelous nation peace would be realized practically among the peoples of this beautiful continent." Salvador accepted with enthusiasm "the generous proposals of the government of the United States, congratulating it on becoming the common guide in this work of civilization and peace, being destined to exalt the good name and secure the progress of these republics." Nicaragua approved the "philanthropic proposal that your Government has in view." Honduras accepted the idea of a peace congress which "for the good of Latin America and the United States would solve questions of the greatest interest for the future of the American nations."

The resolutions and recommendations of the conference were very general since the territory was too new, the principle of cooperation untried and the questions too complicated to allow them to undertake the elaboration of definite projects for treaties or laws with any assurance as to their results. Also the mutual relations of the powers involved were not sufficiently well defined to allow for more definite treatment of the subjects under discussion.

The matter of compulsory arbitration, which was to become the "eternal question" of these conferences, as it had been before in the first series, was discussed and a majority of the members of the Congress voted for its recommendation. The delegates from Mexico and Chile, however, were opposed to this convention. Recommendations were also made relating to reciprocity treaties, postal communications, customs regulations, port duties, the free navigation of American rivers, sanitary regulations, a monetary union, - weights and measures, patents and trademarks, an international American bank, an intercontinental railway, the extradition of criminals, and several other matters.

No definite results were achieved, however, except 'the establishment of an International Bureau of American Republics in Washington, for the collection and publication of information relating to the commerce, products, laws and customs of the countries represented. It was decided that it should operate under the supervision of the Secretary of 
State of the United States. It was established in 1890 with an annual budget of $\$ 36,000$ to be furnished by the different countries in proportion to their populations. This was the beginning of that most useful institution that is now known as the Pan American Union.

Secretary Blaine, in summing up the work of the Congress, said:

"If this Congress had only one of its acts to be proud of, we should call the world's attention to the reasoned, confiding and solemn consecration by the two vast continents of the maintenance of peace and prosperity, the offspring of peace. We look upon this new Magna Charta which suppresses war and substitutes arbitration among American governments in its place, as the first result and most important one of the International American Congress."

This conference differed from most others in that it was not convened for the settlement of a specific diplomatic problem nor did it confine itself to the discussion of any definite interest. It had the character of a general advisory meeting of the representatives of neighboring countries summoned for the purpose of bringing these countries into closer touch with one another and of arriving at a better mutual understanding. Definite results could not be hoped for, but the discussion it was felt would be beneficial to all the nations concerned.

\section{THE SECOND PAN AMERICAN CONGRESS}

President McKinley was favorable to the Pan American movement but shortly after his accession to the presidency the United States became involved in a war with Spain, during and after which it was doubtful as to what influence might be exerted by it on the relations between the United States and Spanish America. But in his message of Dec. 5, 1899, he suggested the holding of another Pan American Congress. The Mexican government which under Diaz was sitaying very close to the United States, gave the invitation to all the American Republics. On October 22, 1901, the 
congress opened its sessions in Mexico City, and continued in session until January 3I, I902. Representatives of all the American nations were present.

The chief subject of discussion was obligatory arbitration. During the first few weeks of the sessions relations were somewhat strained, since Chile was ready to withdraw if the subject was brought up, on account of her troubles with Peru over Tacna and Arica. Brazil also was strongly opposed to the discussion on account of boundary questions with her western neighbors.

The Argentine delegation to the Congress presented a brilliant document in which an exhaustive review was given of that country's treaties of arbitration and of its references to arbitrable justice and arbitrable jurisdiction in America. It was added that "the day will arrive when all the arbitrable jurisdiction will be inclosed within a single article of universal positive law, compiled in analogous wording to that of the treaty celebrated between Argentina and the kingdom of Italy on June $23,1898 . "$ That treaty provides that:

The high contracting parties obligate themselves to submit to arbitrable judgment all disputes of whatever nature that from any cause whatsoever may arise between them during the existence of the present treaty in regard to which no friendly solution may have been attained as the result of direct negotiation. It matters not that such controversies may have originated in circumstances which may have sprung from facts anterior to this stipulation in the present treaty.

After much wrangling a majority of the delegations signed a project whereby their countries should become parties to the Hague Conventions of 1899 , which provide for voluntary arbitration. At the same time ten delegations signed a proposal for a treaty providing for compulsory arbitration. These were the delegations from Argentina, Bolivia, Guatemala, Mexico, Paraguay, Peru, Salvador, Santo Domingo, Uruguay and Venezuela.

The conference also approved a project for a treaty whereby controversies arising from pecuniary claims of individuals of one country against the government of another should be submitted to the arbitration court established by 
the Hague Convention. The conference requested the United States and Mexico to negotiate for the admission of the other American republics to the Hague Conference. The application to the Hague Tribunal to regulate controversies between American states rising out of private claims may be well considered an important milestone in the progress of the world toward a normal and continuous application of international law.

This conference ratified a resolution of the First Conference recommending the construction of complementary lines of the proposed Pan American railway and adopted resolutions approving many steps calculated to bring about closer commercial relations. In the matter of international sanitation the successful work of the United States in Havana, Santiago and other Cuban cities had created a general demand for the extension of such methods for the suppression of epidemics throughout both continents.

Although by 1906 , date of the Third Conference, neither Argentina, Chile nor Brazil had adopted any of the treaties proposed by the conference, and the United States had only accepted the convention concerning pecuniary claims, the Second Conference represents a decided progress in the development of American international relations. For the second time it had been possible in the presence of radical differences of opinion to find a basis for mutual understanding and for cooperation in a number of important matters.

\section{THIRD PAN AMERICAN CONGRESS}

The Third Pan American Conference was held at Rio de Janeiro, July 2 Ist-August 26th, 1906. The United States and all the Latin American countries, with the exceptions of Haiti and Venezuela, were represented. The conference met in Monroe Palace under most auspicious circumstances, since it had behind it the long record of peace and goodwill between Brazil and the United States. A notable contribution to this conference was the address of Elihu Root, then Secretary of State of the United States, who was at the time making his memorable visit to South America. He said, in part : 
"I bring from my country a special greeting to her elder sisters in the civilization of America. *** Unlike as we are in many respects, we are alike in this, that we are all engaged under new conditions, and free from the traditional forms and limitations of the Old World, in working out the same problem of popular self-government. *** Nowhere in the world has this progress (that of the world towards more perfect popular self-government) been more marked than in Latin America. Out of the wrack of Indian fighting and race conflicts and civil wars, strong and stable governments have arisen. Peaceful succession in accord with the people's will has replaced the forcible seizure of power permitted by the people's indifference. Loyalty to country, its peace, its dignity, its honor, has risen above partisanship for individual leaders.

"It is not by national isolation that these results have been accomplished, or that this progress can be continued. No nation can live unto itself alone and continue to live. Each nation's growth is a part of the development of the race. There may be leaders and there may be laggards, but no nation can long continue very far in advance of the general progress of mankind, and no nation that is not doomed to extinction can remain very far behind. It is with nations as it is with individual men; intercourse, association, correction of egotism by the influence of others' judgment, broadening of views by the experience and thought of equals, acceptance of the moral standards of a community the desire for whose good opinion lends a sanction to the rules of right conduct-these are the conditions of growth in civilization.

"To promote this mutual interchange and assistance between the American Republics, engaged in the same great task, inspired by the same purpose, and professing the same principles, I understand to be the function of the American Conference now in session. There is not one of all our countries that cannot benefit the others; there is not one that cannot receive benefit from the others; there is not one that will not gain by the prosperity, the peace, the happiness of all. These beneficent results, the Government and the people of the United States of America greatly desire. We wish for no victories but those of peace; for no territory except 
our own; for no sovereignty except the sovereignty over ourselves. We deem the independence and equal rights of the smallest and weakest member of the family of nations entitled to as much respect as those of the greatest empire, and we deem the observance of that respect the chief guaranty of the weak against the oppression of the strong. We neither claim nor desire any rights, or privileges, or powers that we do not freely concede to every American Republic. We wish to increase our prosperity, to expand our trade, to grow in wealth, in wisdom, and in spirit, but our conception of the true way to accomplish this is not to pull down others and profit by their ruin, but to help all friends to a common prosperity and a common growth, that we may all become greater and stronger together."

The subjects considered at this Third Congress were much the same as at the two preceding. With respect to arbitration this conference passed a resolution that the delegates from the American republics to the Second Conference at the Hague be instructed to endeavor to secure there "the celebration of a general arbitration convention so effective and definite that, meriting the approval of the civilized world, it shall be accepted and put in force by every nation."

It was considered unwise to pass any resolutions concerning the collection of debts by force of arms, since the nations represented were chiefly debtor nations. It was therefore recommended that the "Governments represented therein consider the point of inviting the Second Peace Conference at the Hague to consider the question of compulsory collection of public debts, and, in general, means tending to diminish between nations conflicts having an exclusive pecuniary origin."

With respect to copyrights, patents and trademarks this conference reaffirmed the convention of the Second Conference, with some modifications: two international bureaus, one in Havana and one in Rio, were established for the registration of patents and trademarks, etc.; provision was also made for a center of sanitary information in Montevideo; with respect to naturalization it recommended that whenever a native of one country who has been naturalized 
in another again takes up his residence in his native country without intending to return to his adopted country he should be considered as having reassumed his original citizenship.

The Bureau of the American Republics was reorganized at this conference. Its duties were defined as follows: to assist in securing ratification of resolutions and conventions adopted by the conferences; to prepare complete reports upon problems especially committed to it by any conference to be subjects of discussion at later meetings; and to act as a bureau of educational information. Each country was called upon to appoint a permanent commission on Pan American affairs. With the cooperation of these commissions the Bureau of American Republics was directed to make special investigation into the conditions of internal improvements and the laws governing mining and forest conserves in the various American states, and make the bureau an efficient agent in the internal development of the American republics. Most of these countries were in need of capital and immigrants and it was believed that by the diffusion of correct information concerning industrial conditions a valuable service might be rendered.

The Third Conference was distinguished from its predecessors by the fact that the plans for the regulation and arrangement of it and its discussions had been made by the governing body of the Bureau of American Republics, and the time allowed for its sessions was not to exceed six weeks. The feeling was general among those who arranged it and those who composed its membership that it would not be advisable to inaugurate sweeping policies or attempt radical changes. It sought to improve conventions already existing and devote itself to detailed structural changes and administrative arrangements. Its action was mainly suggestive, calling attention to new lines of international activity, new possibilities of development, and charging the Bureau of American Republics to make preliminary investigations. The debates took place within committees and the resolutions there adopted were accepted without dissension on the part of the -conference. Its predecessors had been characterized by serious debates. The conventions adopted by the Rio de Janeiro Conference have received much attention 
from the American governments and have been quite generally ratified.

\section{THE FOURTH PAN AMERICAN CONGRESS}

The Fourth Conference, held at Buenos Aires, July-August, I9IO, commemorated the independence of the American nations and their willingness to continue to act upon the basis of a common American policy. It was carried on under rules and regulations laid down by the governing board, so that it was possible for it to confine itself to the task of working out treaties and resolutions on the subjects of the program. The business of the conference was distributed among fourteen committees, on six of which every delegation was represented. These committees considered the various questions, which included the matter of improvements in the organization of the Pan American Union; the completion of the Pan American Railway; the establishment of a more rapid steamship service between the republics; uniformity in consular documents and customs regulations; international sanitation; treaties on arrangements concerning copyrights, patents and trademarks; treaties on the arbitration of pecuniary claims and the interchange of professors and students among the American universities.

In the matter of copyrights, etc., it was agreed that rights of literary property obtained in one state, in conformity with its laws, were to be of full effect in all others without the necessity of fulfilling any further formality, whenever there appears in the record some statement indicating the reservation of the property right.

Measures regulating the rules of procedure of the conference were passed. A regulation was established that subjects not included in the program should not be introduced unless by a favorable vote of two-thirds of the members. This rule found its basis in the important fact that international conferences are not composed of legislators but rather of delegates working under instruction of their governments. It is therefore necessary that the subjects to be discussed shall be known to the governments beforehand in order that they may instruct their delegates how to act.

It was also decided that a government which has broken 
off diplomatic relations with the government acting as host to the conference is entitled nevertheless to send a delegation. Republics not having diplomatic representatives in Washington may entrust their representation to other members of the body who then have a vote for each country represented. Full enjoyment of the rights of membership is based upon the maintenance of a stable and undivided government.

The organization and duties of the existing Bureau of American Republics were still more clearly defined at this conference. The presidency of this institution was accorded to the Secretary of State of the United States, according to the common international practice of giving similar positions to the minister of foreign relations of the country in which the union has its seat. It was also felt that the dignity and efficiency of the Bureau would be increased in this way. The name of the organization was changed to "The Pan American Union."

Its functions were enlarged: to compile and distribute data and information regarding commerce, industry, agriculture, education and general progress in the American countries; to collect and classify information concerning treaties, etc., between the American republics; to contribute to the development of commerce and intellectual relations between the American republics; to act as the permanent commission on international American conferences; to present to the various governments a report on the institution's work, before the meeting of each conference. Its meetings shall be held monthly and be composed of representatives of American states which maintain diplomatic representation at Washington. Five members form a quorum. Any government has the right to withdraw from the Union upon giving two years' notice to the Secretary of State of the United States. Only the essential bases of the organization were laid down, leaving to the director and the governing board the power to determine all details concerning the performance of the mission of this union. It is a truly international agency. Its action is based upon the unanimous consent of all the states composing it and no power or group of powers claims for itself a determining influence. 


\section{PAN AMERICAN CONFERENCES}

The committees during the Buenos Aires conference were given time and opportunity for a thorough discussion of their respective subjects. The manner in which the conference proceeded was exceedingly businesslike. It did not spend its efforts in spectacular oratory, somewhat to the disappointment of the local press, but directed itself quietly and persistently to the accomplishment of the purposes before it-that is to improve, in general bearing and detail, the relations between the republics along the lines determined by the program of the conference.

One of the most interesting happenings in the conference related to the discussion concerning the Monroe Doctrine which was carried on privately between several delegations but never brought on the floor of the conference itself. Since it is an interesting sicle light on our general subject as well as on the workings of these conferences, we will follow the discussion as reported by the Chilean diplomat, Alejandro Alvarez. It seems that the late Ambassador of Brazil to the United States, his Excellency Señor Juaquin Nabuco, had cherished the idea of presenting to the conference at Buenos Aires a motion which would register the recognition by all the countries of America of the fact that the Monroe Doctrine had been beneficial to them. Nabuco, at his death, had left in writing a formal declaration, which the Government of Brazil, out of respect to the memory of the great statesman, desired to have presented to the conference without change. His Excellency, Señor Da Gama, Brazilian ambassador to Argentina, presented the matter previously to Argentina and Chile, saying that his government was desirous of counting in this move on the cooperation of Argentina and Chile. The proposition, furthermore, was to be presented only in case the acquiescence of all the other delegations could be counted on beforehand, so that it would be approved without criticism.

The resolution of Nabuco, endorsed by the Brazilian delegation, was in these words: "The long period which has transpired since the declaration of the Monroe Doctrine permits us to recognize in it a permanent factor making for international peace upon the American Continent. For this reason, while celebrating the centenary of her first efforts 
towards independence, Latin America sends to her Great Sister Nation of the North, an expression of her thanks for that noble and unselfish action which has been of so great benefit to the entire New World."

Chile did not feel, however, that she could indorse such a resolution, and proposed the following as a substitute:

"Since their independence the nations of America have proclaimed the right thereby acquired of excluding European intervention in their internal affairs, and, also, the principle that the territory of the New World cannot be made the object of future colonization. These principles, clearly formulated and solemnly expressed by President Monroe in I823, constitute a factor which has contributed towards guaranteeing the sovereignty of the nations of this continent. Wherefore Latin America, celebrating the one hundredth anniversary of her independence, sends now to the Great Sister Nation of the North the expression of her adhesion to that idea of solidarity, as in the past she joined her in proclaiming those principles and upholding them for the benefit of the entire New World."

Señor Alvarez of Chile and Señor Da Gama of Brazil then got together and agreed on the following compromise resolution:

"The long period which has transpired since the declaration of the Monroe Doctrine permits us to recognize in it a permanent factor making for external peace upon the American Continent. It gave concrete and solemn expression to the aims of Latin America from the commencement of her political independence. For this reason, while celebrating the centennial of their first efforts towards independence, the nations represented in the Fourth Pan American Conference send to their Great Sister Nation of the North the expression of their adhesion to that noble and unselfish action, of such beneficial consequence for the New World."

This was presented to the delegations of Argentina (all but two members of which approved it as drawn up) and 
Chile, the members of which believed that another formula must be sought which would not lend itself to false interpretations by Europe, the United States and the rest of America. Their proposal was in the following terms:

"Upon celebrating the centennial of their first efforts towards political independence the nations represented in the Fourth Pan American Conference send to their Great Sister Nation of the North the expression of their thanks, and record the conviction that the declarations contained in the message of President Monroe met the aims of all America and contributed effectively to guarantee its independence."

By now the situation was complicated. The delegation of the United States, consulted in regard to the whole matter, made it clear that while it would be very acceptable for Latin America to make the Monroe Doctrine hers, if in doing this she was going to create dissensions in the assembly, it was preferable to make no presentation of the subject at all. The Brazilian delegation thus realized that a unanimous assent to its views was not easy to obtain; for though everyone agreed as to the basic factors of the resolution it was very difficult to reduce it to a brief form satisfactory to everybody. In view of this the delegation did not further push its project.

So, while all the countries of America there represented were agreed that the Monroe Doctrine, as it was formulated in 1823 , is in accord with the aims of the New World and forms a part of its public law, yet it was very difficult to find a wording, which, without exciting the susceptibility of Europe, would be satisfactory to all the countries of America. There were some states which desired to see incorporated with the principles of that Doctrine other principles limiting the hegemony of the United States.

Such conferences as those held at Washington, Mexico, Rio de Janeiro and Buenos Aires are by nature informatory rather than administrative. They determine the bases for unanimous or almost unanimous international treaties. But they have been highly appreciated by the public and the press of Latin America. The indications are that an in- 
creasing number of their proposals will be ratified by the nations concerned. They have done much to develop a desire for the solidarity of America.

The concrete results of these conferences have not been much greater than the series formerly held in South America, but the fact that the Pan American Union exists and has the opportunity to do a really constructive work means that, as the American nations grow to realize their community of interests, the importance of its services and the weight of its decisions will increase and it will form a bond among the American states. As Don Alejandro Alvarez says: "The happiest results of the Pan American Conferences are that they harmonize all the states of America and that they contribute powerfully in developing and forming upon its true basis the American Conscience, a conscience which is one of the characteristics of the contemporary political life of the States of the New World."

\section{VARIOUS ASPECTS OF PAN AMERICANISM}

Pan Americanism has two aspects, the relations of all America to non-American powers and the relations of the various American nations to one another. The first aspect of the matter has been looked at with much unanimity, the United States announcing it through the Monroe Doctrine and the other governments taking practically the same attitude individually, if not always in specific pronouncements.

As to the second aspect, the relations of American Governments with one another, there are five questions that stand out prominently-commercial intercourse, arbitration, boundary questions, intervention, and mediation. We have seen that commercial intercourse and arbitration were thoroughly treated in Pan American Congresses. The last three matters, boundaries, intervention and mediation, are more delicate and more difficult and have had less frank and open discussion.

It must be said to the credit of the American nations that, while there have been a great many international differences among them concerning boundary lines, these problems have 


\section{PAN AMERICAN CONFERENCES}

almost always been settled by arbitration. For example, the question of boundaries between Argentina and Chile, which first arose in 1843 , had brought about quite a serious situation in $188 \mathrm{I}$. The ministers of the United States in Santiago and Buenos Aires brought about the signing of a treaty by these two nations, which it was hoped would settle the matter. Among other things this treaty stipulated a resort to arbitration should the question be brought forward again, as it was in 1896 . It was upon this occasion that W. I. Buchanan performed an outstanding service as a Pan American, in his capacity as Minister of the United States to the Argentine. Through the satisfactory decision of the King of England, as arbitrator, in 1902, the dispute was finally settled. In commemoration of the happy termination of the controversy a statue of Christ, the Prince of Peace, was erected on the crest of the mountains which form the boundary between Argentina and Chile. It is known as "El Cristo de los Andes," and appropriately bears witness to the noble spirit and idealism to which it is a monument. On the base of this most unique monument are written these impressive words: "Sooner shall these mountains become dust than that the peoples of Argentina and Chile shall break the peace which they have pledged at the feet of their Redeemer."

\section{INTERVENTION}

The governments of Latin America have continually opposed the policy of outside intervention in the internal affairs of any of the American republics. Alberdi is the one outstanding statesman who was willing to admit intervention and even recommended the inclusion of the principle in the public law of the continent. Calvo, on the other hand, who claimed that the independence of the states, with all the corresponding rights, must be absolute, represents the general position of Latin America on the subject. Intervention may be diplomatic, pacific, armed, official or unofficial, but the term is generally understood to mean armed intervention. The French intervention in the Rio de la Plata from 1838 until 1840 , the Anglo-French from I 848 to 1850 , and the joint action of England, France and Spain against 
Mexico, in $\mathrm{r} 86 \mathrm{r}$, and the intervention of Germany, France and England in Venezuela in 1902 are the outstanding armed interventions in American affairs by European nations.

Armed intervention in Latin America, or at least in the Caribbean district, by the United States has lately become rather frequent. As pointed out in a later chapter, it has included sending armed forces into Cuba, Nicaragua, Haiti and Santo Domingo. Some classify the capture of Vera Cruz and the Pershing Expedition as intervention in Mexico. But these had specific objects of punishing particular deeds and did not extend to taking over the country. Some also claim that non-recognition of a government, in the case of the United States and the rest of America, where the former has so preponderant an influence, is equivalent to intervention. Theoretically the United States has always stood for the doctrine of non-intervention in the internal affairs of a sovereign nation. That was clearly involved in Washington's doctrine of no entangling alliances. General Grant said in his Message to Congress, December 6, 1869:

"As the United States is the freest of all nations, so, too, its people sympathize with all people struggling for liberty and self-government, but while so sympathizing it is due to our honor that we shall abstain from enforcing our views upon unwilling nations and from taking an interested part, without invitation, in the quarrels between different nations or between governments and their subjects."

Our statesmen still talk that way, as a usual thing, but a different practice has been followed in the Caribbean, and the jingoes are continually urging intervention in Mexico and other countries where commercial interests are disturbed. Other reasons, such as the protection of nationals, may be alleged, but the supreme reason for intervention is almost universally financial. The right and the justice of such intervention continues to be a much debated subject.

While the practice of states is quite well established in dealing with two of the three kinds of claims that citizens of one country may hold against the government of another 
-tnose for injury to person, the destruction or confiscation of property, or pecuniary obligations-claims of the third class have received little attention from writers of international law because states have, in the past, usually drawn a sharp distinction between contractual and other claims, largely disregarding the former.

In 1848 Lord Palmerston stated that the government of Great Britain has usually considered it undesirable that its subjects should invest their capital in loans to foreign governments, instead of employing it in profitable undertakings at home ; and that with a view to discouraging hazardous loans to foreign governments the British government had hitherto thought it best to abstain from taking up as international questions complaints made by British subjects against foreign states. This policy was reaffirmed by Lord Salisbury in 1880 .

The policy of the United States, which is substantially in accord with the above, is well summarized in a dispatch of Secretary Bayard, dated June 24, I885: "( I ) All that our Government undertakes, when the claim is merely contractual, is to interpose its good offices; in other words, to ask the attention of the foreign sovereign to the claim; and this is only done when the claim is one susceptible of strong and clear proof. (2) If the sovereign appealed to denies the validity of the claim or refuses its payment, the matter drops, since it is not consistent with the dignity of the United States to press, after such a refusal or denial, a contractual claim for the repudiation of which, by the law of nations, there is no redress."

President Roosevelt in an address given on December 6, I904, said:

"Any country whose people conduct themselves well can count on our hearty friendship. If a nation shows that it knows how to act swith reasonable efficiency and decency in social and political matters, if it keeps order and pays its obligations, it need fear no interference from the United States. Chronic wrongdoing, or an impotence which results in a general loosening of the ties of civilized society, may in America, as elsewhere, ultimately require interven- 
tion by some civilized nation, and, in the western hemisphere, the adherence of the United States to the Monroe Doctrine may force the United States, however reluctantly, in flagrant cases of such wrongdoing or impotence, to the exercise of an international police power."

The last clause of this message contains the principle upon which arrangements were made with Santo Domingo to collect her customs and pay her debts.

The most important case involving collection of debts owed Europeans by an American republic was that of Germany, Great Britain and Italy against Venezuela in 1902. The nature of these claims and their collection raised all kinds of questions. The German claims may be taken as typical; one was for dividends guaranteed by the Venezuelan government on railroad stock of a line built by German subjects at a cost of nearly $\$ 20,000,000$ and for the recovery of interest in arrears on public bonds issued to cover the above; another of $\$ 400,000$ was for the recovery of forced loans made during the civil wars of I898-I900. The English and Italian claims were similar.

The German government secured the permission of the United States, by assurance that no violation of the Monroe Doctrine was intended, to ask Venezuela to acknowledge her claims and that a mixed commission be appointed to further consider the matter. Secretary Hay called attention to President Roosevelt's message of December 3, I90I, wherein he proposed that the United States act as an "international police power" or agent of collection in such cases. The matter dragged on for a year, when on December 20 , 1902, Germany, Great Britain and Italy established a warlike blockade of Venezuelan harbors, without declaring war. This met with strenuous objection from the United States and through her insistence, an agreement was reached whereby Venezuela recognized the justice of a part of the claims, promising to set aside 30 per cent. of her customs receipts for the payment. It was agreed that the claims be submitted to a mixed commission. The blockading powers demanded payment of their claims before those of the peace powers. Venezuela insisted that all creditors be treated 
alike. The demand for preferential treatment was submitted to the Hague Tribunal and was allowed in a decision rendered February 22, 1904.

One of the results of the Venezuelan Claims Case was the pronouncement of the Drago Doctrine. Briefly, this means that public debts give no right to armed intervention or the occupation of territory of a debtor state. This was a long stride ahead of the old position taken by the countries which intervened in Mexico in 1862, in which intervention in its initial stages the United States acquiesced.

President Roosevelt also declared that the Monroe Doctrine would not be stretched to protect the Latin American countries in evading the payment of debts. With the question of the Venezuelan claims of Germany in mind, he said in a message to Congress on December 3, 1901 :

"This (Monroe) Doctrine has nothing to do with the commercial relations of any American power, save that it in truth allows each of them to form such as it desires. In other words, it is really a guarantee of the commercial independence of the Americas. We do not ask under this Doctrine for any exclusive commercial dealings with any other American state. We do not guarantee any state against punishment, if it misconducts itself, provided that punishment does not take the form of the acquisition of territory by any non-American power."

It was this declaration that brought the vigorous protest from the Argentine Minister of Foreign Affairs, whose position that nations did not have the right to intervene for the collection of debts became known by his name. In this message Drago contended that the "collection of loans by military means implies territorial occupation to make them effective, and territorial occupation signifies the suppression or subordination of the governments of the countries on which it is imposed."

The Second Hague Conference received the Drago Doctrine with the utmost sympathy. While the Conference did not go the entire length of the Drago Doctrine, it did, in adopting the Porter Proposition, provide for obligatory ar- 
bitration in the collection of contractual indebtedness before a resort to arms.

By the Calvo Doctrine, announced a little later, the Argentine statesman of that name pushed still further the objection to allowing foreign claims to threaten a nation's sovereignty. The Calvo Doctrine claims that governments are not responsible for losses and injuries received by foreigners during internal disturbances. Calvo says:

"To admit the principle of indemnity would be to create an exorbitant and pernicious privilege, essentially favorable to strong states and injurious to feebler nations and to establish an unjustifiable inequality between nationals and foreigners. *** To sanction such indemnity, we should do, although indirectly, a deep injury to one of the constituent elements of the independence of nations, that of territorial jurisdiction."

It is interesting to note that this advanced position was taken in the treaty signed by Peru and Argentina on March 9, I874.

\section{MEDIATION}

As to mediation, the three outstanding cases where proffered good offices were freely accepted by both sides were: Mediation by Mexico and the United States in the Central American Question in 1907, when, because of the succession of attempts at union and separation among the five Central American Republics, Mexico and the United States in a sincere desire to help those unhappy countries to bring about peace, offered jointly their good offices. A great achievement was accomplished by the conference which followed, in the establishment of a Central American Court of Justice "For the purpose of efficaciously guaranteeing their rights and maintaining peace and harmony inalterably in their relations, without being obliged to resort in any case to the employment of force." There followed, in I9I0, the successful mediation of the United States, Argentina and Brazil in the settlement of a serious boundary dispute be- 
tween Peru and Ecuador, which threatened to involve Bolivia, Chile and Colombia; and finally that of Argentina, Brazil and Chile in the difference between the United States and Mexico in I9I4.

The successful Central American mediation will be treated in the chapter on the Caribbean. The "Mexican Mediation" of I9I4 had a profound effect all over Latin America, as indicating the willingness of the great Northern Republic to submit its American relations to the friendly consideration of other American countries, in the same way it had advocated others doing. It marked a new day in Pan American friendship when the United States and Mexico accepted the following proposal of the Ambassadors of the A B C countries: "With the purpose of serving the interests of peace and civilization on our continent and with the earnest desire to prevent any further bloodshed, to the prejudice of the cordiality and union which has always surrounded the relations of the governments, and peoples of America, we, the plenipotentiaries of Brazil, Argentina and Chile, duly authorized hereto, have the honor to tender to your Excellency's government our good offices for the peaceful and friendly settlement of the conflict between the United States and Mexico."

I happened to be in Argentina at the time the mediation was announced. There was a tremendous change in public sentiment. Student demonstrations in favor of Mexico and public meetings to protest against Yankee invasion of Latin America were called off and the public press radically changed its tone. As Dr. Francisco Castañeda of El Salvador says :

"A most important happening, one which the political and the sociological world must take seriously into account, has just taken place, based on the unfortunate situation in Mexico and the international conflict which seemed imminent between that convulsed nation and the United States. The fact to which I refer is the generous attitude assumed by the three most important nations in South America, Argentina, Brazil and Chile, by means of which their representatives in the city of Washington have offered their good 
offices to the contending countries in order to find a solution of the difficulties and to eliminate a conflict which would have such disastrous results. The conferences of Niagara Falls have held during three months the interests of the whole continent and the debate of such an illustrious assembly has interested the press everywhere, coming to a climax when the resolutions were adopted which eliminated the war between the United States and Mexico. The A B C powers will from now on, because of these results, be a moral and political entity which will have great influence in the whole continent."

\section{THE RESULTING PAN AMERICANISM}

Pan Americanism has come to be of much greater importance of recent years because of the growing recognition by the rest of the world of the importance of the IberoAmerican countries. At the opening of the twentieth century those countries were an unrecognized power in the council of the nations, in international commerce and world peace. As Ugarte said, they were standing on the margin of the horizon of international life at the opening of the present century. Their advance into a position of importance in world affairs has been most remarkable. In 1906 Secretary Root made his remarkable journey through the South and attracted the attention of the world to these countries whose history and potential resources he so faithfully interpreted in a series of remarkable addresses. In 1907 the Latin American delegates for the first time took their place at the Council table of the nations and astounded the world by the brilliancy of their representatives at the Hague Conference. In I9IO the beautiful building of the Pan American Union, due to the munificence of Andrew Carnegie, was dedicated as the impressive shrine of American Unity and the workshop of practical American cooperation. In I9I5 the Panama Canal was opened and sent forth a flood of compelling motives for world interest in Latin America. In 1916 there was held at Panama the Congress on Christian Work in Latin America, which brought together representatives of more than fifty religious organi- 
zations from twenty-two nations to study the spiritual, educational and social problems of these southern lands, and aroused a widespread interest in the churches and educational circles of the United States in their southern neighbors. In IOr $=$ there was held in Washington the first Pan American Financial Congress, which began the movement of American capital and ships toward the South. The following year the Second Pan American Scientific Congress met in Washington and brought to the attention of the cultural world the notable circle of intellectuals of the Latin American countries.

In the meantime a remarkable number of well-known men from Europe and North America were making visits to the South and telling the world about the great physical and intellectual riches which they there discovered. Among those visitors were such makers of public opinion as Clemenceau, Bryce, Altamira, Prince Henry, Blasco Ibañez, Bryan and Roosevelt, all of whom wrote material reporting their visits, which was read in all parts of the world.

Add to all these things the great progress which has been made in Latin America in the last twenty years and the hurling together of all the nations by the World War, and we have the principal reasons why these lands, so long isolated, have now come to occupy a prominent place in the thought of the world. And their prominent place gives added importance to the question of Pan Americanism.

What is Pan Americanism? Some will think this question should have been asked and answered much earlier in this discussion. But Pan Americanism is more of a sentiment and an aspiration than a tangible svstem which can be confined within certain limitations of definition.

The term itself is comparatively modern. It was first used in connection with the first Pan American Conference which met in Washington in 1889-1890. The New York Evening Post seems to have been the first to employ the term, in its edition of the 27th of September, 1889. Following that the term was used in the Washington Conference, though the official title of that gathering was International American Conference. It is only since the beginning of the twentieth century that the term has come into popular use. 
It recognizes that the American states form in the world an independent political factor and possess a political system of their own. It emphasizes the principles of political action created by the American states in the course of their mutual relations and stresses the moral union of these states based on a body of principles developed during their struggle for independence and for a real democracy. Lockey, who has made one of the most careful studies of the question, says that these principles are independence, unity of political idealism, territorial integrity, predominance of right over force, non-intervention, equality, cooperation.

The new International Encyclopedia defines Pan Americanism as the principle of an alliance or a political union of the various states of the western hemisphere; also the life of the American people expressed in the republican form of government and tending toward such a union. Murray calls it the idea or sentiment of an alliance or political union of all the states of North and South America. The Hispanic-American Encyclopedia defines it as the aspiration or tendency of the people of the New World to establish between themselves a bond of union, to promote a good understanding and harmonious fraternity between the states of the continents and to work always together against the domination and the influences of European powers in American territory.

Blaine, who called the first Pan American Conference, said that the Garfield government had two purposes in its international policy: "First, to develop peace and to prevent future wars in North and South America; second, to cultivate such relations of friendship and commerce with all the American countries as would develop a considerable commerce of exportation from the United States and furnish to the Latin American nations those articles with which we are amply able to compete with the manufacturing nations of Europe. In place of friendly intervention here and there, bringing about a treaty between two countries, settling some dispute between two others tomorrow, it was evident that a more comprehensive plan should be adopted if these wars were to cease on the .Western hemisphere." Pan Americanism, then, signified to Blaine peace and com- 
merce, as a result of friendly advice and the cooperation of all the American states for the benefit of all.

President Roosevelt, in his instructions to the delegates of the United States to the Second International Conference, meeting in Mexico in I90I, declared: "The principal interest of the United States in respect to the other republics of the American continent is the security and permanence of the political system in which they find their existence and the existence of our own nation, the system of government by the people themselves. It is therefore to be desired that all the American republics enjoy completely the benefits of perfect liberty under just laws, each sovereign nation pursuing its own course of ordinary development without limitations or intervention from the outside. Nothing is of greater importance from the political point of view than the understanding that the United States are the friends of all the Latin American republics and are not the enemy of any. For this purpose it will be prudent not to propose anything radical, to favor a free expression of opinion among all the delegates of the other countries and to submit only those propositions that have the weight of general expectation and clearly tend to promote the common good."

John Bassett Moore declared before the Pan American Financial Congress in 1915: "The idea that America is not simply a geographical term, but a term representing a unity of interests, has existed so long that it may be presumed that it is not a false term, but one that carries us absolutely and persistently along the right road. The word 'America' since the beginning of the last century during the struggle of our neighbors for independence, represented the idea of a community of political interests. As Henry Clay said: 'We ought to be looked upon as united in the purpose of establishing a league of human liberties.' This idea has advanced gradually until today we are beginning the establishment of a community of interests we have had for many years; we proceed now to complete this circuit, installing the identity of material interests upon the ample bases of justice, contentment and fraternity."

Such outstanding Latin Americans as Baron de Rio Branco of Brazil, Luis M. Drago of Buenos Aires, Señor 
Casasus of Mexico have used the same expressions of approval of Pan Americanism. In the Third International Conference Señor Cornejo of Peru said: "These congresses, gentlemen, are the symbol of that solidarity which in spite of the ephemeral passions of men constitutes by the invincible force of circumstances the essence of our continental system. These conferences were conceived by the organizing intelligence of the statesmen of Washington to exalt the sentiment of American patriotism. Liberating it from national egotism which might be justified in the difficult moments of the beginnings of states, but which would today be an obstacle in the development of the American idea, destined to demonstrate that as the democratic principle has been the combination of liberty and order in the constitution of the state, it will combine, also the governments of the nations and fraternity in the relations of peoples."

On the occasion of the laying of the corner-stone of the new Pan American Building in Washington, May I I, I908, some notable speeches were made concerning Pan Americanism, among them that of the Minister of Brazil to the United States, Señor Nabuco. He said:

"Gentlemen, there has never been a parallel for the sight which this ceremony presents-that of twenty-one nations of different languages building together a house for their common deliberations. The more impressive is the scene as these countries, with all possible differences between them in size and population, have established their union on the basis of the most absolute equality. Here the vote of the smallest balances the vote of the greatest. So many sovereign states would not have been drawn so spontaneously and so strongly together, as if by an irresistible force, if there did not exist throughout them, at the bottom or at the top of each national conscience, the feeling of a destiny common to all America. It seems, indeed, that a decree of Providence made the western shore of the Atlantic appear late in history as the chosen land for a great renewal of mankind. From the early days of its colonization the sentiment sprung in the hearts of all its children that this is really 


\section{PAN AMERICAN CONFERENCES}

a new world. That is the sentiment which unites us together on this auspicious day. We feel we are all sons of Columbus."

The eternal negative is voiced in the following words of Jacinto López of Venezuela :

"A system contrary to that of Europe, not of violation but of adhesion and fidelity to principle, is the one supposed to rule in America, and from this system there naturally develops Pan Americanism as an expression of solidarity and fraternity-of a numerous family of nations united in sincere love of justice and right and in its just practices in all mutual relationships.

"But is this true? Unfortunately, no. It is as untrue in America as in Europe. History tells us that since 1846 , that is since the Mexican War, an open war of conquest, the United States has continued to violate the principles of what is known as Pan Americanism.

"There has not been, nor is there, nor can there be a real Pan Americanism until the United States abandons its territorial expansion and domination in America. Pan Americanism and imperialism are mutually exclusive and incompatible. The one destroys the other. Panama, the BryanChamorro treaty and its antecedents, the military occupation of Santo Domingo and its history, say clearly that Pan Americanism does not exist, or exists as an abstract conception. Until the United States respects other American nations Pan Americanism will be simply the mask of imperialism."

In spite of this sentiment of the Pan Latinists, the fact is that the definition of Pan Americanism that has carried the greatest hope to and won the largest acceptance in Latin America has been the one given in his Message to Congress in 1916 by President Wilson, when he said:

"The moral is, that the states of America are not hostile rivals but cooperating friends, and that their growing sense (If community of interests, alike in matters political and in 
matters economic, is likely to give them a new significance as factors in international affairs and in the political history of the world. It presents them as in a very deep and true sense a unit in world affairs, spiritual partners, standing together because thinking together, quick with common sympathies and common ideals. Separated, they are subject to all the cross-currents of the confused politics of a world of hostile rivalries; united in spirit and purpose, they cannot be disappointed of their peaceful destiny. This is Pan Americanism. It has none of the spirit of empire in it. It is the embodiment, the effectual embodiment of the new spirit of law and independence and liberty and mutual service."

As we come to the close of this section of our study in which we have reviewed the historical development of American unity with all the conferences and movements of both North and South America which have striven toward such solidarity, the words of B. Vicuna Mackenna, written a half century ago, seem to be peculiarly appropriate:

"The work of the Panama Congress was sterile because it was the daughter of fear of Alexander of Russia; as was also the failure of the Congress of 1848 , due to fear of the Spanish Queen Cristina ; that of the Triple Alliance of 1856 , due to fear of Walker. All these federations have been simply between governments themselves and they have been based on selfishness and immediate need. There has not been up to the present a proposal for a real American Federation, an alliance of peoples, fraternity of nations, league of Republics. The people should raise their voices in unison and send to one another their fraternal embrace. Love will then rule, not fear. And thus and only thus will the American Federation be a fact. Then will the destiny of this our common fatherland be assured, the most magnificent of the five great continents which the hand of the Eternal One formed in the mold of His Omnipotence and which a sublime pilot called "The New World" because in its dimensions it was like unto a second marvelous Creation." 


\section{Sources of Further Information on Pan American Conferences}

Annals of the American Academy of Political and Social Sciences,

Number 124, Articles on Fourth Pan American Congress by

Henry White, Paul S. Reinsch, Alejandro Alvarez.

BARRETt, John: The Pan American Union.

Calderón, F. García: Ideas y Impresiones, Chapter on Pan Americanism.

Gil, ENrique: Pan Americanism and International Policy of Argentina.

LatanÉ: The United States and Latin America, Chapters V and VI.

Lima, M. DE Oliverra: Pan Americanismo, Bolivar, Monroe, Roosevelt.

LoCKEY, Jos. B.: Pan Americanism, Its Beginnings, Chapter I. López, Jacinto: El Panamericanismo, La Reforma Social, September, 1919.

MOORE, JoH N BAsSetr: Digest of International Law, American Diplomacy.

Quesada, Ernesto: El Nuevo Pan Americanismo.

Reinsch, PAul S.: Public International Unions.

Reports of Four Pan American Conferences.

Report of Second Pan American Scientific Congress. Root, Elihu: Latin America and the United States.

Shepherd, William R.: Hispanic Nations of the New World. World Peace Foundation, The New Pan Americanism. 


\section{Chapter VII}

\section{LATIN AMERICA AND THE WORLD WAR}

To say that Hispanic America along with all other nations and peoples of the world has been profoundly affected by the World War is only to state a commonplace. However, since these nations saw no fighting and sent no organized military forces to the front, there are few who recognize how profound a change the war really brought to them. And it is doubtful if anywhere in the world the good results were so preponderant over the evil as here. These nations, said by Ugarte a few years ago to be on "the margin of international life," have gained by the war a definite place at the council table of the nations. The world at large has a new appreciation of them, both for what they are and what they may become. With a new choice of suitors from Europe, Asia and North America, and an opportunity to play the one against the other, with a fresh recognition of their own powers and their duty to develop these, with a new appreciation of the seriousness of right decisions when facing moral and spiritual problems in international as well as national life, with a revelation of their own impotency in a world crisis and of the weakness of their educational and social systems-Latin American nations have indeed entered a new epoch. If they do not overstep themselves in playing international politics but modestly build more firmly their present advantages into permanent friendships, and faithfully devote themselves to the development of their remarkable economic and spiritual resources, a few decades will see changes that will astound and delight the world. This conviction has increasingly grown on the author as he has visited seventeen out of the twenty southern republics since the United States entered the war. 


\section{ECONOMIC CHANGES}

The first changes to be felt in Latin America consequent upon the war were economic. South America had depended chiefly upon European capital for its development. England had invested in Argentina alone some five hundred million pounds sterling. Railroads, port works, street railways, mines, telephones and extensive land projects were owned by Europeans. Latin America had been selling her enormous resources to the foreigner and living in ease on the proceeds, with no thought that in this modern world of science and commerce and wealth such conditions could ever change. If a nation desired a new loan for some pet project or for the reward of a political party, a concession to a foreigner would bring it. If the rich estancicro desired a new palace, the foreigner was ready with the money in exchange for some of his valuable land. If native labor was scarce or indolent, immigrants from Spain and Italy would come to reap the crops and build public works.

When the European war began all of this order of things, which had come to seem most natural, was suddenly changed. Countries which were not only accustomed to borrow extra funds but to receive money for their raw materials from the foreigner, found both processes stopped because the European kept both his capital and his ships at home. For the same reasons that made foreign money unavailable, foreign goods and foreign labor were unobtainable.

In an endeavor to extricate herself from this trying situation Latin America did two things which are making a profound and permanent change in her life. The first was to turn to the United States for aid. The American Government, answering the appeal, called the first Pan American Financial Conference, which met in Washington in May, 1915. The Ministers of Finance and prominent bankers of practically every one of the twenty southern countries, as well as the leading financiers of the United States, attended the conference. By it was established the International High Commission, a composite body with official representatives from each American republic.

The program of the Commission, as laid down, covered 
a wide but well-considered range, embracing: ( I) The establishment of a gold standard of value; (2) uniform customs regulations; (3) the international protection of trademarks, copyrights and patents; (4) the establishment of a uniform low rate of postage and the improvement of the money order and parcels post facilities between the countries of the Americas; and (5) the extension of the principle of arbitration to include the adjustment of commercial disputes.

In addition to these subjects the International High Commission, at a later meeting in Buenos Aires, dealt with the extension of banking facilities and credits, international agreements for uniform labor legislation, and improved telegraph and transportation facilities between the American republics, including the use of wireless telegraphy for commercial purposes. The work of this Commission and other influences have had remarkable results in developing InterAmerican commercial relations.

At the beginning of the war there was not one North American bank operating in South America and not a North American steamship line maintaining passenger service between the two continents. At the beginning of I92 I there were some fifty North American branch banks in South America, besides an equal number in the Caribbean section, a district which is now doing two billion dollars' worth of foreign commerce annually. The National City Bank of New York controls some forty-two of these banks and the Mercantile Bank of the Americas about twenty-five. The American dollar is everywhere substituting the English pound, and a number of governments have recently made the dollar legal tender, and in other countries it freely circulates, so that a visitor need not bother with exchange in Cuba, Santo Domingo, Haiti, Guatemala, Honduras, E1 Salvador, Nicaragua and Panama. In the provinces of Lima and Callao, Peru, it was decreed that the administrators of public revenues should receive as payments only checks lithographed in the United States. The Department of Cauca, Colombia, negotiated a loan of I,000,000 pesos gold with a New York firm recently. Within the past half-dozen months the Bolivian Government has 
contracted for a loan of Io million dollars with a New York investment house. The State of Santa Catharina, Brazil, has arranged a loan of 5 million dollars in the United States for the construction of railways and for public utilities. Among the other loans that are being increasingly arranged in North America the most important one recently is that placed by Chile in February of 1921 for 20 million dollars.

Half a dozen years ago, out of a thousand vessels entering Latin American ports, scarcely any flew the American flag. In I9I3, according to the United States Bureau of Foreign and Domestic Commerce, "not a single American vessel arrived at Buenos Aires. In 1914 there were $6:$ in 1915,73 ; in 1916, 140; and in 1917, 151." In 1919, 335 American vessels carrying 822,609 tons arrived in the Argentine. In the first four months of 1920 American tonnage at Buenos Aires exceeded by 3 per cent. the total American tonnage at that port for the whole year 1919, in which year it stood second to British tonnage only. In I9I4, the limit reached by American tonuge for the foreign trade was $1,076,000$ gross tons; in Murch, 1920 , it was 9 million tons, or more than the total tonnage of all classes for I9I6; and the entire tonnage is, in 1921 , approximately 16 million tons. Though working under stupendous pressure, British shipping, always immeasurably superior to other shipping, can now barely keep ahead of American production. This, too, like the banking development, is an entirely new economic fact, and is bound to modify the current of foreign relations in Latin America. What the ultimate outcome will be, since Great Britain, the United States, and Japan are all in a frenzy of ship-building and have their eyes on the Latin American trade, probably nobody can say today.

The total value of commerce between Latin America and the United States has shown an enormous increase since the beginning of the war. In 1913 that commerce amounted to 743 million dollars. In 1919 it had grown to practically 3 billion dollars. In I9I 8 our trade with the West Indies amounted to four times what we did with Great Britain in 1913, and Argentina's business with us was five times as inuch as we did with France in I9I3. In 1919, in spite of disturbed conditions in Mexico, we sold her more farming 
implements than we did France, at that period supposed to be in greatest need of such material. Our commerce with Uruguay grew from 5 I million dollars in 1918 to 81 million in I9I9, or 58 per cent.; our trade with Colombia reached the record value of 67 million dollars, showing a gain of 90 per cent. over the 1918 trade; imports from Venezuela in I9I9 increased I70 per cent. over the 19I8 figure, and exports to that country showed an equal gain.

\section{DEVELOPMENT OF HER OWN RESOURCES}

Besides Latin America's endeavor to arrange for new credits and supplies in the United States, she did a second thing which is destined to have a very large effect on all her life. She began to make a most determined effort to develop her own resources and to manufacture her own goods.

This movement was most notable in Brazil, the one big country in South America hat actually declared war. The federal government took up systematically the whole question of increasing agricultural products and cattle raising and the manufacturing of goods formerly imported. Previously her export had been largely coffee, with the proceeds of which she had bought many staples which could have been easily raised at home. In the new effort toward development, a North American missionary was called upon to help in planning a corn exhibit and other methods of increasing production like those used in the United States, and several thousand Japanese colonists were brought in to teach the people to grow rice cheaply. The methods of producing rubber began to be reformed. The coal mines in the south were again opened. An official campaign around the world was initiated to promote the sale of Brazilian tea, mate. Manufacturing has grown to an astounding extent. Brazil is now almost entirely shod with nationally made shoes. The importation of hats in Sao Paulo has practically ceased because of the nineteen hat factories now in that city. Native textile products are rapidly replacing the foreign makes. Brazil's shipping industry has profited enormously by the taking over of nearly fifty interned Ger- 
man ships, with which it is planned to establish lines between Brazil and many other countries, including Chile and China.

The demand in the warring nations for beef and wheat, and the high prices paid, caused a great increase in their production. Argentina has now become the leader of the world in the exportation of beef, surpassing the United States and Australia. She has also come to occupy first place in the export of wool and third place in the export of wheat. She has begun the use of native petroleum and firewood, and to search for her own coal deposits and exploit her own forests since denied these necessities by Europe. Argentina's total foreign commerce for 1920 approximated the remarkable figure of 2 billion American dollars. Argentina's trade balance in her favor for 1919 was 375 million dollars. Her per capita foreign business amounts to more than $\$ 200$ per capita, whereas that of the United States is estimated at \$86. Chile has learned her lesson as did Brazil, not to depend entirely on one product for her national commercial existence. Heretofore about 85 per cent. of her national revenue had been derived from an export tax on nitrate, but during the war taxation was distributed in a more scientific way, including a land tax which Chile had never had before.

As one Chilean has said, "The war has brought us a certain prosperity and also something that is worth more than prosperity-common sense." Chile had already encouraged manufacturing to some extent, there being some 8,000 factories employing 90,000 persons in 1914. This number has been greatly augmented since that time. Chile now gets practically all of her coal from her own mines.

Peru has also been led to stimulate greatly her production of sugar and cotton, the high price of these articles during the war having brought producers of these products great prosperity. Her inability to get needed food supplies and manufactured goods has caused this country also to make a splendid endeavor to supply her own needs.

The smaller countries in the Caribbean have been less able to develop their own resources and as a rule have greatly suffered economically. Cuba is a marked exception. That 
country's foreign commerce has been multiplied by three during the war on account of her giving herself almost entirely, backed by American capital, to the production of sugar. Cuba now produces about one-quarter of the world's supply of sugar. Her foreign commerce in 1918 amounted to 718 million dollars and in 1920 to about one billion dollars. Her per capita wealth is now more than that of the United States, and her foreign commerce about equal to that of China.

"The imagination is almost overpowered in attempting to comprehend the vast proportions of the sugar industry of the island as it exists this year.

"The cane produced is of such tremendous volume that a procession of bull teams, four abreast, reaching around the earth, would be required to move it. The crop would suffice to build a solid wall around the entire 2,000 miles of the island's coast line as high as an ordinary dwelling house and thick enough for a file of four men to walk abreast on it.

"The sugar extracted from this cane would load a fleet of steamers reaching from Havana to New York, with a ship for every mile of the $\mathrm{I}, 200$ that stretch between the two ports. The great pyramid of Cheops, before whose awe-inspiring proportions millions of people have stood and gazed in open-mouthed amazement, remains, after 5,000 years, unrivaled as a monumental pile; but Cuba's sugar output this year would make two pyramids, each outbasing and overtopping Cheops.

"The wealth the outgoing sugar crop brings in is not less remarkable in its proportions. Four hundred dollars out of a single crop for every human being who lives on the island-a sum almost as great as the per capita wealth produced by all the farms, all the factories and all the mines of the United States!

"What wonder, then, that Cuba today is a land of gold and gems, richer than Midas ever was, converting Crœesus, by contrast, into a beggar!" 1

All this prosperity means that Hispanic America is not

1 Of course Cuba and all Latin America have been deeply affected by the post war financial crisis. But this is no doubt only temporary. 
only a market for our manufactured goods, but also a great source of energy and economic strength in the rehabilitation of the world. It is sometimes said that the only source of credit for the current needs of Europe is in North America. The United States may be the only place where very large issues of bonds could be floated, but international banking and mercantile organization is even now drawing upon the surplus credit-strength of the rich overseas parts of the world. The basic sources of credit in South America are furnishing now the means of supplying Europe on a basis of deferred payment. Moreover, the new financial position of South America is being consolidated in a movement of those republics whose money has been on a fluctuating basis to put their currency and banking systems upon a sound and stable footing, backed by gold. Within five years all South America south of the equator will be on the "gold basis."

The premier industries of South America in all probability will always be the former ones, that produced vast quantities of raw materials. Meat, wool, wheat, linseed, hides, tanning extract, coffee, cocoa, rubber, copper, tin, nitrate, will always be the great "money makers" and the South American contribution to the world's manufacturing. Lumber and beautiful woods are to be added and there may come a great development of cotton production. South America has all along furnished some good cotton and sugar. To these products, moving in heavy volume, there is now being added a very respectable total of minor ones, such as rice, beans, canned vegetables and fruits, butter and cheese, and wines. There is some prospect of South America developing a tanning industry that may eventually export leather in place of hides. The South American growth of manufacturing is important, but it is only complementary to the premier industries of the "camps" and the forests.

It is therefore of great significance that the agricultural industries and the country life of Brazil, Uruguay, and Argentina are waking up to something absolutely new to them. A. progressive element among the farmers is absolutely hungry for new ideas of "scientific" production.

The third change in economic conditions during the war has been the development of the labor movement. Labor in 
these countries in the past has had little opportunity to assert itself. The formation of the Pan American Federation of Labor in 1918, which is fostered by the American Federation of Labor, has served to organize labor in several Latin American countries. Three Pan American conferences on labor have been held, resulting in an understanding between workmen of different countries and helping them to study more closely the economic, social and political inıprovements of the laboring classes.

The objects of the Pan American Federation of Labor, organized at the first of these conferences, are stated as follows :

First. The establishment of better conditions for the working people who emigrate from one country to another.

Second. The establishment of a better understanding and relationship between the peoples of the Pan American Republics.

Third. To utilize every lawful and honorable means for the protection and promotion of the rights, the interests, and the welfare of the peoples of the Pan American Republics.

Fourth. To utilize every lawful and honorable means for the purpose of cultivating the most favorable and friendly relations between the labor movements and peoples of the Pan American Republics.

At the Second Pan American Congress it was brought out that the offices of the federation had acted as an information bureau for the labor movements of the $\bar{P}$ an American Republics, and had collected considerable data concerning labor conditions in the Western Hemisphere, especially in connection with the state of organization of the workers.

It was found that the labor movement had been organized into a national federation or body, outside of the United States and Mexico, in Argentina, Paraguay, Uruguay, Guatemala, Salvador, Chile, Peru, and the Dominican Republic. In those countries not mentioned there are quite a 
number of labor unions, but they have not formed into a national organization.

In the three conventions of the Pan American Federation and in the work of ad interim committees delicate international questions have been courageously faced. As the then secretary of the Federation, Señor Luis Marones, said: "It is time the workers of the world found a way to remedy the mistakes of government. It is their duty to deal with international differences, when governments do not care to settle them, and try to prevent conflicts among workers." Mr. Samuel Gompers in his second inaugural address said: "Anything that makes for international unity and the prevention of international strife and war is the proper work of the labor unions of the world."

The Federation has already, acting on this principle, taken up three problems that affect American peace. The first was that of relations between Mexico and the United States. The inside story of the influence of labor in preventing an armed conflict between the two countries would reveal an important contribution in this regard. At the Second Annual Convention, held in New York, July, I919, a resolution was adopted under which the Federation promised to use its good offices toward effecting a settlement of the boundary dispute between Chile and Peru. Delegates said it was the duty of labor to end this controversy of many years' standing, as there was danger of war in which the workers would be the chief sufferers. Objection was made by the delegates from Ecuador that the resolution was of a political character, but Mr. Gompers said that if the workers of Germany and Austria had had the courage and intelligence to set themselves against the action of their governments the war of the past five years would not have occurred.

The most instructive work done toward establishing right relations between the United States and Santo Domingo is being carried out by this Federation. The Dominican delegates to the first conference presented complaints concerning some injustices to labor practiced by the American forces in occupation. This led to President Gompers writing to President Wilson, setting forth at length the whole 
question of American occupation. Later the American Federation of Labor appointed a commission, which in January of 1920 visited Santo Domingo and made a careful study of the labor conditions and the question of the military occupation. This commission submitted thirty-four proposals to the government for the betterment of the conditions of the people, a number of which were immediately carried out by the officials. No doubt this work has had much to do with bringing about of the recent announcement of the United States Government that the marines are soon to be withdrawn from the Dominican Republic.

The Third Convention of the Federation, which was held in Mexico City in January, I92 I, witnessed a very severe test of the organization when radicals and extreme nationalists made a strenuous effort to disrupt the organization. But the saner element prevailed, and passed the following resolution, which sums up the purposes of the Federation:

"Whereas, it is the aim and purpose of the Pan American Federation to use every proper and legitimate means to advance the interests of the working people; be it

"Resolved, That the following is expressive of our desires and purposes and sets forth principles which we consider fundamental:

"Political freedom, the right of the workers to have a voice and vote equal to that of every other citizen is the first practical step toward those individual rights that are essentialito liberty. But political liberty, working through legislative, executive and judicial departments of the organized government of a free people does not, and should not be permitted to enter into that personal (non-governmental) relationship between wage-earner and employer through which the terms of employment are determined by the recognition of equality of rights, and the joint agreement of both parties.

"The trades union movement holds that the principle of self-government by free peoples and the principle that in industry and commerce the wage-earners through their organization should freely and fully participate in determining the terms of employment, are identical. The principle that 
governments should only exist with the consent of the governed is identical with the principle that the terms of employment, conditions of labor and the rules and regulations of employment should only exist with the consent of the employed.

"We regard it as essential to the success of our movement that there be a clear and definite statement as to the attitude of this federation toward questions subject to controversy and honest difference, not only because of our desire to promote understanding among those now affiliated to the Federation, but so that those not yet affiliated may the more readily understand the character of our Federation and the more quickly assume their proper responsibilities by seeking affiliation.

"We, the delegates assembled in this congress, regard it as essential that it be established as a foundation principle that progress can be achieved only through agreement. The aim of our federation must be to find those programs, principles and tactics upon which agreement can be had. This federation has a right to life only because it is of service to the workers and there is no service in disunity and disharmony. Those matters regarded as essential by some, but not by all, should be held in abeyance until the processes of education, understanding and experience develop agreement among all. Any effort to force upon minorities principles or tactics to which they cannot give consent, must, in an international Federation such as this, lead to destruction. In like manner any effort of minorities, through strategy or otherwise, to thrust their decisions upon majorities must be equally fatal. "We call the attention of all workers to the vital need of education as a prime requisite of intelligent progress. WVe set it down as a fundamental fact that a high state of democratic civilization and enlightenment cannot be founded upon ignorance. The more highly our civilization is developed, the more complete must be the degree of education, enlightenment and understanding of the workers if democracy is to be preserved and its opportunities kept open to those who do the useful work of all nations.

"We urge upon all affiliated organizations, and upon labor movements everywhere, the prime necessity of encouraging 
education, of insisting upon education and of securing the just right to participation in the development and administration of education.

"Our movement is a movement of protest against wrong and injustice and a movement of constructive progress. We cannot develop beyond the understanding of the working people everywhere. Without an intelligent and understanding labor movement, capable of receiving and transmitting thought and capable of a proper appraisal of facts, conditions and theories, there can be only chaos or tyranny. Proper education is a first requisite of democratic constructive progress.

"One of the primary conditions essential to the success of our movement in our respective countries as well as that of the Pan American Federation of Labor is the organization of the yet unorganized wage workers, whether skilled or unskilled, into unions of their trades, callings or industries and the unity of these organizations for the cultivation of the spirit and action of fraternity and solidarity.

"We regard as essential the extension of democracy in industry and we declare our unalterable opposition to interference in the processes of industry by forces outside of the industrial field and therefore incompetent to deal with its problems. We urge upon the labor movement everywhere the extension of the practice of negotiation between the employers and the workers and the making of trade agreements. We hold this to be the first great step in the development of democracy in industry and we hold that in no other way can such democracy be developed. There is no democracy while the workers are inarticulate and the workers can have no effective voice except through organization in the industrial field."

Labor disturbances have occurred all over Latin America during the last two years. Just how far these have been due to the efforts of foreign agitators and how much to the growing spirit of independence among the workers themselves, it is difficult to say.

The most serious strike took place in Buenos Aires during I9I9. That city of a million and a half people has suf- 


\section{LATIN AMERICA AND THE WORLD WAR 239}

fered probably more than any other since the close of the war by the continuous strikes which blocked all ocean traffic, closed all the great daily papers for two weeks and brought on what was practically a political revolution. Extensive labor troubles were also registered in Brazil, especially around Sao Paulo. Strikes in the mines and ports of Peru served to bring about serious conditions in that country. Strikes in Havana, Cuba, and in Oriziba, Mexico, among the tobacco workers in Porto Rico, the stevedores in Chile, and others of more or less importance, have served to bring to the front the tense situation of the laborers in all these countries.

Socialistic and labor representatives are found exercising large influence at the present time in the national congresses of Chile, Argentina, Uruguay, Brazil, Porto Rico, Mexico and Cuba. Several governments have recently deported large numbers of aliens who have taken part in labor disturbances, Argentina during July, I919, having deported about 900 on a special ship chartered for that purpose. Since the war has brought to the fore the questions of socialism and unionism, they promise to be among the most vexing of all the problems facing these countries for the next few years.

FIGHT FOR COMMERCIAL AND CULTURAL SUPREMACY BY OTHER WORLD POWERS

Finally, in discussing economic changes in Latin America during the war there must be mentioned the attention commanded from the rest of the world by these nations because of their enormous resources. Careful students are now regarding this as the most promising field for furnishing the three great demands of the world today: food, room for overcrowded populations, and a market for surplus goods and capital. Beginning at the Rio Grande and stretching down through Mexico, Central America and through the untold riches of South America to the Straits of Magellan, is the largest area of undeveloped fertile land in the world. Capitalists, manufacturers, steamship directors, food economists and political leaders in North America, Europe and 
even Japan, are intently fixing their attention on these fallow lands. A German observer has lately described Latin America as the "Fair Helen" of the business world. Her charms are admired and her favors sought by all industrial nations.

It is interesting to glance at what a few nations are doing to woo this fair maiden. The French, who have always had a profound influence on the Latin American republics, seemingly without any particular effort on their part, have recently organized a French-American Committee which is to direct a movement to unite France and Latin America; to develop economic, intellectual and artistic relations; to attract students and travelers to France, and to encourage every means of bringing these countries together. A good deal is being said about the necessity of the Latin races uniting. All of this has its advantages in the development of commercial relations. A Latin American Week has recently been celebrated in France. The visits of such men as Clemenceau to Latin America have been a strong means of cultivating these relations during the past, and it is proposed that these visits shall be continued on a much larger scale.

An article by George Lafon, recently appearing in the Revue Minerva, says: "One of the inevitable consequences of the European War will be a most terrible competition in the markets of Latin America. This contest will not be limited to commerce but will extend itself to all of the fields of human activities. There will be a political, financial, industrial and intellectual contest. It is necessary to prepare for it. Only a few years ago South America was of little importance in the world: immense territory and small population; weak nations agitated by internal disorders; a civilization in evolution but far removed from us. Today, on the other hand, Argentina, Brazil, Chile, Uruguay and other nationalities have a homogeneous people, numerous population and stable and strong government. The world importance of these young American republics consists in their agricultural and mineral wealth, which has scarcely been touched. 
"There are two competitors, Europe and the United States. The United States displays the Monroe Doctrine to exclude, if possible, from the southern markets European capital and production. That political doctrine includes also an economic domination. But the South prefers her liberty to a purely geographical union. Her points of contact with North America are few; neither language nor race, nor religion, nor customs are included. She will gain little if she enters into the orbit of the United States, but on the contrary will lose much.

"The most active elements in South America today are European emigrants that have maintained close relationships with their fatherland, and the sons and descendants of emigrants who feel and call themselves 'sons of the country' but who do not wish to deny that they are Latins : latinity is not a vague and literary phrase, it is a real thing in many economic and political problems. The Latin republics of America feel their affinity of race for the Latins of Europe. We must prepare promptly an army of young men for this new struggle, an army that does not need to be so numerous but well chosen. Only thus shall we be able to conquer the place which the Latins deserve in South America."

England discovered Latin America more than a hundred years ago. Her relationships have been largely commercial. She is now not only endeavoring to recapture her trade lost largely to the United States during the recent hostilities, but also to establish it on a firmer basis of cultural relations than existed before the war. Many books on the Latin American countries are published in England by English authors. Her schools are founding professorships in the Spanish and Portuguese languages and are studying Latin American history as never before. An Anglo-Spanish society has recently, been formed, and other movements are noted which show her earnestness in the matter.

Germany has for many years made South America one of her chief points of commercial attack. Her large colonies in the different countries and her merchants in every commercial center in Latin America have not lost as much as might be supposed during the war. Germany is pre- 
pared to make the greatest fight of her life for trade in all parts of Latin America. Directly connected with this movement is the promotion of emigration to these countries in large numbers through a semi-official emigration bureau.

Japan has recently developed steamship lines to Peru, Chile, Argentina, Brazil and Mexico. She has also established emigration to Brazil and her people have been entering Peru in large numbers. To be reckoned with as local competitors are the large numbers of Syrians and other near-eastern nationalities who are increasingly becoming the leading merchants, especially in the Caribbean countries.

All are developing their shipping interests. Of British efforts, nothing need be said. It is a foregone conclusion that Great Britain will meet every advance put forth by competitors.

The French Compagnie Générale de Transports Maritimes has instituted a regular service between France and the Caribbean and Mexican ports and San Francisco via the Panama Canal. The Transatlantica Italiana and the $\mathrm{Na}-$ cional de Navegación have already sent steamers to Chile by way of Panama and expect to add ten more vessels, receiving a substantial subsidy from the Chilean Government. Suárez and Company, of Havana, have established a line between Havana, the United States, and the Argentine. The Compagnie Générale Transatlantique began last December monthly sailings to the West Coast of South America by the Panama route. Ex-German vessels seized by Portugal have been assigned to Portugal-Brazil service. The firm of Henry Frank and Co. has initiated steamship service between the Argentine and southern Brazil; the New York and Cuba Mail Steamship Co. plans a monthly service between European and Mexican ports and has added new passenger and freight service between New York and Mexico; the Pacific Steamship Co. now connects San Francisco with Corinto, Nicaragua, by boat, has inaugurated a direct line of steamers between New York and Callao-Valparaiso, and is expecting soon to replace smaller vessels serving San Francisco and Central American cities by 5,000-ton vessels; the Companhia Minas e Viação de Matto Grosso of Brazil has let contracts in the United States for the construction 


\section{LATIN AMERICA AND THE WORLD WAR 243}

of twenty ships; the Compañia Viajera Antillana has been formed in Havana with a capital of $\$ 4,000,000$ and is having seven steamships built in England and in the United States; the Holland-American Line is to establish service between Valparaíso and other Chilean ports and Panama; the Latin American Line has begun to run between New York and Santo Domingo and Colombia.

The European nations are using especially the power of the friendly visitor to capture the sympathy of Hispanic America, whose temperament makes her particularly susceptible to this kind of approach. Since the war closed Belgium has sent her hero King, France has sent Premier Viviani, and Italy Premier Orlando. The most notable reception seems to have been given to distinguished Spanish visitors, such as Ferdinando, Prince of Bavaria, thus showing the remarkable revival of close relations with the mother country, Spain, which has come to be particularly noticeable during the last year. In order to promote further these relations King Alfonso himself is now planning an inclusive visit. Besides these men distinguished in political life there have been any number of less known men touring these countries as individuals or members of commercial, scientific, literary or diplomatic commissions.

As to the activities of the United States for developing closer contacts with Latin America reference has already been made to the Pan American Financial Congress and the activities growing out of it, as also to the Pan American Federation of Labor. The Second Pan American Scientific Congress, held in Washington in 1916, and the movements growing out of it, did much to remove the complaint of the Latin Americans that the United States was interested in them chiefly from the commercial side, failing to appreciate their contribution to science, literature and art. Besides the continual activities of the Pan American Union, with headquarters in Washington, there have been developed a large number of societies and innumerable publications for the promotion of various phases of inter-American relations.

The Committee on Cooperation in Latin America represents a large movement among the churches of the United States to cultivate friendly relations with their Southern 
neighbors and help them to solve their problems by sending ministers, teachers, physicians and social workers who will share with them the best of North American life. The Committee is especially devoted to the production of literature, particularly the translation into Spanish and Portuguese of some of the best North American books. It publishes a review, La Nueva Democracia, which is probably the only publication in the Spanish language that offers a common platform on which all the Americas may discuss their spiritual problems.

Universities and colleges of the United States have organized special courses in the languages and history of Latin America, and have made the attendance of Latin American students much easier. Latin America has come to be an increasingly popular subject to discuss with commercial organizations and chautauqua audiences. Banks, factories, steamship companies and engineers have made elaborate plans to extend trade toward the south. It may be said that for the first time in its history the United States is awake to the need of developing close relations with her southern neighbors.

During the war, then, and partly on its account, all the principal industrial nations of the world have come to appreciate in a new way the importance of Latin America, and have resolved to win commercial and cultural supremacy in these twenty young and rich republics, where the struggle for such supremacy will be keener than in any other part of the world.

\section{POLITICAL CHANGES}

The technical attitude of the Latin American countries in the world war was as follows:

Eight of the twenty nations actually declared war on Germany. These were Brazil, Costa Rica, Cuba, Guatemala, Haiti, Honduras, Nicaragua and Panama. Five other Latin American states broke off diplomatic relations with Germany, namely, Bolivia, the Dominican Republic, Ecuador, Peru and Uruguay. Salvador declared herself in favor of benevolent neutrality toward the United States, which per- 
mitted the use of her ports and territorial waters by the warships of the United States and the Allies. The six remaining neutral nations, Argentina, Chile, Colombia, Mexico, Paraguay and Venezuela, either by the statements of the executives or by resolutions passed by their congresses, or again by the pro-Ally tone of the majority of their leading newspapers and finally by the utterances of their most representative statesmen, also expressed themselves in favor of Pan American solidarity. ${ }^{1}$

The outstanding change in the political life of Latin America brought about by the war, was its new attitude of friendliness toward the United States. It is not necessary here to refer to the well-known suspicion of the United States which has existed in all Latin American countries for years. This prejudice and the change of sentiment are well described in the following editorial published in a leading Buenos Aires daily on July 4, I9I7:

"The circumstances in which we find ourselves today on this anniversary of the North American nation serve to define a double principle of Americanism and democracy. This celebration in other years has been an occasion for re. joicing only for the United States. She could, with patriotic joy, stop in her march and contemplate with satisfaction the road traveled since the days of that memorable declaration. Other people joined the celebration with a cordiality more official and diplomatic than real.

"Today all is different. The United States, by the power of that great republican virtue which is the supporter of the right, is for the whole world not only a nation engaged in a knightly war, but an apostle in action. Some four years ago the Latin author, Ruben Dario, was able to say, led astray by superficial observation, that the United States, which had everything, lacked but one thing-God.

"Today this cannot be said, for the crusade of the United States and the serene and eloquent words of Wilson have a religious character, now that they intimate the abandonmer.t

1 The causes of the various attitudes assumed by the different Latin American nations have been the subject of much treatment in current literature to which reference is made at the end of this chapter. 
and disregard of material interests in the face of the defense of the ideal.

"Quietly, without the sound of trumpets or noise, the United States has entered the contest, and thus it returns to noble France the generous contribution of that great Frenchman, Lafayette, the American national hero. If America stands for anything in the world and in history it is liberty. Other peoples have been formed by reason of conquest, or of religion, but the Americans were born out of the idea of liberty.

"In this sentiment is found the unity of San Martin, Bolivar and Washington. It matters little that history registers this or that disturbance and this or that variation. That is the sentiment, and that is the thing that, after conquering all cruel tyrannies and retrogressive desitions, has overcome all.

"So, in the awful conflict which today is shaking the world, the United States is bearing the burden of all America, because she is on the side of liberty. She is the big sister in years and in power among the American nations. This place belongs to her and worthily has she taken it."

Dr. Ernesto Quesada, of Argentina, speaking of the need of all America standing together, said: "Never more than at the present moment, while Europe is in the great conflict of nations, has America been confronted with a more vital necessity to stand together." Señor Ignacio Calderón, of Bolivia, put it this way: "Freedom is a gift that is only given to nations who know how and are ready to defend it. America is destined to lead the world. Let us work together for the principle of right and justice, of liberty and happiness." Dr. Edward J. Pinto of Costa Rica was even more emphatic: "It would seem," he said, "that by a natural reflex action Americans, having witnessed the result of upheaval and conflict across the Atlantic, have banded together in order that the bonds of their security and peace may be strengthened and assured."

Many volumes could be filled with such quotations.

A Latin American writer, discussing the effect of the arrival of the United States Army at the front, says: 
"The Americans arrived in time! It was because they had a pure ideal. Benignant Destiny willed that those who had least material interest involved in it should decide the war. The dominating word of the President explained to the New Men that the future of Liberty and of Democracy was in peril, and they marched bravely to the field of battle. Ancient Britain defended her Empire and her maritime power; France and Italy their integrity; the New Men defended their ideal, the dictates of their consciences, the good of all, the spiritual heritage, the right of coming men to breathe with sovereign lungs in the atmosphere of the earth. Because they were building a dwelling worthy of the future humanity, they had been called materialists. $* * *$ But when the deceptive mist fades away, our eyes, filled with the limpid grace of comprehension, behold the Uncle of the Big Stick transfigured into an heroic paladin."

Just as the United States entered the war the writer began an extended trip through the southern hemisphere. All throughout my tour, beginning at Mexico, I felt this change in sentiment. But not until I arrived in Chile did it come over me with full force. On my visit three years before I felt like leaving Chile on the first train, for I heard on every hand unpleasant references to the United States. The students of the universities were particularly hostile. This time, when I called upon a professor in the National University, I was asked to address one of his classes; later on, another; till I found myself giving a whole morning of talks. These led to a conference at one of the big theaters, secured for the occasion by the university students. The theme they wanted me to discuss was, "How to Develop Closer Relations between the United States and Chile." At the close of the lecture a full hour was spent answering their eager and pointed questions. I spoke very frankly; analyzing the good and bad in the Anglo-Saxon and the Latin, pointing out why each had failed to understand the other in the past. That session with these brilliant young people was a most delightful experience. Their hunger for knowledge about North American life, particularly concerning our universities, was amazing and refreshing. 
For the first time in the history of a South American nation Brazil has openly declared that the prime reason for her taking a serious political step was to follow the leadership of the United States. In her note to the other South American powers, announcing the breaking of relationships with Germany, she said:

"Brazil has never had, nor has it now, warlike ambitions. If it has heretofore abstained from taking sides in the European conflict, it has not been able to continue indifferent since the United States has been drawn into the war without any further motives than simply those of action in the name of international justice and order. $* * *$ If up to the present the relative lack of reciprocity on the part of the American republics has deprived the Monroe Doctrine of its real character, permitting an interpretation scarcely founded on the prerogative of sovereignty, the present conditions place Brazil at the side of the United States of America at this critical moment in the history of the world, and continue to give our political relationships a practical form of continental solidarity."

In the same way Panama, in its declaration of war, says that, "Neutrality is impossible in a conflict where the vital interests of the United States are involved."

The visit of the North American fleet under the command of Admiral Caperton to South American waters in I9I7 promoted these friendly relations in a remarkable way. In order that the fleet might visit Montevideo when Uruguay had not yet broken relations with the Central Powers, the government promulgated the following special decree, which will no doubt be of great weight in future international relationships in America:

"Whereas the Government of Uruguay has proclaimed the principle of American solidarity as a criterion of its international policy, it hereby decrees that no American country, which in defense of its own rights should find itself in a state of war with nations of other continents will be treated as a belligerent." 
In Montevideo the whole program and reception were practically directed by the Young Men's Christian Association, to which the government turned over a large building near the wharf. In this building there were opened a reading-room, a writing-room, a reception hall, and a bureau of information. Ten thousand dollars American gold was exchanged for the visitors in one day. In this same building the Salvation Army conducted a restaurant in which nearly one thousand men were fed daily. Every night there were entertainments of different kinds, furnished largely by the young people of the churches and social organizations.

The last Sunday night of the visit at Montevideo a remarkable meeting was held in this hall, lasting about four hours. The dean of the literati of Uruguay, Dr. Juan Zorilla de San Martin, who is known wherever the Spanish language is read, said, in speaking to the boys:

"It is the breath, indeed, of that great lady of ours, Democracy, my friends, which waves those glorious banners that you unfurl on your mastheads; it is her breath which carries them into this war that America has not provoked but that has struck her to the heart with its mailed fist and has aroused her in the name of her duty toward humanity; it is, in a word, that which now welds in a great embrace your ensigns filled with the light of the stars and ours filled with the splendor of the sun and makes of them one beneficent constellation.

"But this moment has come in which I find myself in relation not with a great multitude or a gigantic collective person but in immediate and affectionate contact with men whom we love individually, with spirits that are to us real favorites; with each and all of you, valiant and good seamen of our great sister, toward whom I feel an irresistible impulse of genuine affection.

"And this constitutes, my friends, the most intimate of brotherhoods. If the fraternity of our countries comes from the common mother, Democracy, this of which I now speak, this which inspires in me such warmth of affection and interest in each and every one of you, this comes from :something higher and more enduring-our common uni- 
versal Father, our Father which is in Heaven, and who is one with the Son whom we all worship, Jesus Christ the Divine Redeemer of men.

"I wish to speak to you of Him on this occasion, my friends and brothers, because I wish to leave in your souls as the most precious remembrance of my country, living and eternal words. Cherish them as precious jewels, in the depths, in the most intimate and hidden recesses of the secret places of your hearts.

"This house that we have specially prepared for you in order that you might pass here in innocent and pleasant occupation your leisure time, in order that you might here find a reflection of your faraway home, in order that you might here renew the memory of your fathers, of your mothers, of your sweethearts, who are now thinking of you; of your native land in which your absence is felt while you are away on the call of your country; this house and this meeting which we offer you show that we Uruguayans have been thinking of you all individually, that we have seen in the crews of your formidable warships not only the units of an army which is passing, but the members of a family, with whom we share our home; not an anonymous group of beings destined to die, but a handful of beloved brothers for whose life we raise our prayer to our common Father and whom we would wish to embrace one by one, to save one by one from the dangers and hidden enemies, not only material but moral as well, which may rise to meet them in their unselfish journeying to and fro by sea and land.

"I see now before me that fair young sailor, almost a child, who looks at me with his large blue eyes full of memories $* * *$ and that other $* * *$ yes, hundreds of others. $* * *$ A profound feeling of personal affection, I was going to say fatherly affection, is awakened in my heart and surges up to irritate my eyes. I am thinking of the pure and lovely things which bind men closest together; I feel that the strongest of ties is being knit between my soul and yours, my brave lads, joyous heralds of Mother America, soldiers of justice, of right, and of peace! Many, and most happy, are the memories left in Montevideo by the notable and gracious visit of the United States fleet to which you 


\section{LATIN AMERICA AND THE WORLD WAR 251}

belong, but, my valiant sailors, of all these memories the most gratifying and lasting is that of your own conduct among us; we have seen you in our streets and even in our churches as models of democratic culture; you have left us the example of an army of gentlemen above reproach, of men truly free and, what is more, of citizens worthy of that freedom, masters of themselves.

"Farewell then, brave soldiers of our free and republican America. I have given you in my words the most precious thing which $I$ have been able to find for you in the depths of my soul, the best that as a parting gift, I believe is to be found among the riches of this my country of Uruguay: paternal inspirations, sincere love for your souls. Everything else passes away, this alone remains to, and throughout, eternity.

"Continue then, with valor and with unwavering faith in victory, your glorious journeyings on the great deep in the beneficent shadow of your spotless banner. Cherish with affection the remembrance of this land of Uruguay, whose fraternal embrace your very hearts have felt."

These remarkable words show not only how the hearts of Americans, North and South, have been opened to one another recently. They show also the significant spiritual currents which have been set in motion recently in the Southern countries.

\section{SPIRITUAL CHANGES}

The outstanding spiritual change brought about by the war is an increased open-mindedness. The people of Latin America are doing more fundamental thinking than ever before in their history. They have hitherto been ruled more by sentiment than by reason. They have rested on the glorious past of the Latin race, have magnified the differences between Latin Catholics and Anglo-Saxon Protestants, and have minimized the great economic and moral bases of American solidarity. They had ceased to regard religion as a real factor in a modern life. But this World War, with its rude shock to their economic progress and to many of 
their philosophic theories, supposedly beyond attack, compelled them to re-examine their individual and national relationships and to restate their theories. The spirit of inquiry, the willingness to listen, the new readiness to seek after God, if perchance they might find Him, impresses one profoundly as traveling in those countries he talks with men of every status from university professors to laboring men.

Not since the struggle for independence a century ago has all Latin America been so stirred with the need of decision on a moral question as during the war. Some of the most dramatic scenes ever enacted in her history took place in the legislative halls and public assemblies when the questions concerning the nation's attitude toward the war were debated. In Peru, Dr. Mariano H. Cornejo, in a brilliant address before Congress September 7, 1917, thus stated the moral issues involved: "Gentlemen, I do not exaggerate when I say that never has Peru had in her past history, never will she have in the future, a greater problem than to decide her attitude toward the world conflict, whose issues illumine the human conscience, bringing to judgment all religious and scientific dogmas, all moral values, all the utopias that man has conceived through the centuries. In the universe reality consists not simply in the material which is temporal. Reality also consists in the intangible light. He does not know reality who does not take into account the unseen energy. $* * *$ Do you know in what consists the supreme science of statesmanship? It consists in knowing which is the hour of ideals and which the hour of personal interest. Lost are the peoples who misread the great pendulum of History. $* * *$ The peoples of America are called upon to enlist themselves on the side of the Ideal. How unfortunate that at this time the ideal is so confounded with personal interest!"

Dr. Leopoldo Lugones, one of the outstanding men of Argentina, in arguing for a visit of the United States fleet to Buenos Aires, said:

"In Argentina neutrality is a desertion. This is true because, in spite of all that is said today, there is no neutrality. Here as in the entire world, there are two powers that com- 
pete with one another-despotism and liberty. And the object of such a gigantic struggle is the right to live with honor, without which even the life of a dog is too sad. This has received since the beginning of the war a sublime ratification. Belgium, only a little atom in relation to colossal Germany, preferred her honor to her life. She gained with this her place of equality among the great. Did I say equality? Historical grandeur has nothing that goes beyond it!"

The following are extracts from an address delivered in the Brazilian Senate on Armistice Day by the well-known Brazilian statesman, Dr. Ruy Barbosa, who was called from his home to address the Senate upon the receipt of the news of peace:

"I have spent the entire morning, until eleven o'clock, in writing at considerable length a reply in the name of Brazilian charity to the appeal of American charity, which is now carrying on a campaign, both there and here, under the auspices of the President of the United States, to provide spiritual, moral and social aid and comfort to the soldiers of democracy, whose mission has not yet been concluded upon the battle-fields of Europe, silent today under the shadow of peace, but agitated still by the birth of the new problems which have followed the war, and which will not be lighter than those of the war itself as a test of the ability and talents of the great statesmen of the period, of the resources and powers of the great nations now crowned with the recent victory.

"I desire to lift up my heart in praise to God for not having permitted me to deceive myself, when, in the conference at Buenos Aires, I counseled our nation, I counseled the other Latin American republics, I counseled the great republic of the north, I counseled all America, I counseled all the neutral countries of the world, to break this unbearable :eutrality between crime and right, between falsehood and "ruth, between infamy and justice. I desire only to say: 'Glory to God in the highest, peace on earth among men of 'good will,' whose faith, whose perseverance, whose heroism, 
took this cause upon their shoulders and bore it to the final victory of this present hour.

"However, gentlemen, there is still another lesson of the war just ended, and we must not forget to make use of it for ourselves, for the salvation of our own country.

"The world moves toward other laws, toward other goals, toward a future of illimitable extent. Crowns have disappeared, democracy seems to be extending its vast dominion over the whole world. All human relationships are changed, transformed, recast, even those between the sexes. The older conditions of life are being swept away in a revolution that may have incalculable results.

"Will it be possible for Brazil in the midst of all these revolutions and upheavals, not to suffer its meed of change in the character of its politics, its institutions, the procedures of its statesmen?

"But, gentlemen, we must be taught by these events, and we ought to realize that our republic must accommodate herself to the new modes of thought, that our government must set its people a different example from the wonted one, or days perhaps tempestuous will be in store for us."

A new humility has come over Hispanic Americans. Countries that have heretofore considered themselves as comparing favorably with some of the big nations of the world have come to realize how utterly inadequate their resources in men and money would be in entering into a contest of the magnitude of the world war. If they have been disillusioned concerning their own strength they have been also concerning the supposed military weakness of the United States. A fable has drifted about that Mexicans believed that if Texas was taken out, she should whip the United States. Certainly Mexico has been entirely convinced by the World War that so far as military force is concerned she would stand no show against the United States. Thus one of the arguments at least of the interventionists is removed, namely, that we ought to whip Mexico because she believed we could not do it.

This realization of the weakness of their national resources and life is causing the leaders in several countries 
to make in a spirit of humility a new study of their economic, educational and social life.

These Southerners have been forced to face many decisions that involved an analysis of moral purposes. They have lived, during the past, rather in isolation, believing that science had solved their problems for them, that nature had given them all that could be desired of riches and prosperity, and that religion had been practically eliminated. But they were suddenly confronted with the necessity of deciding which side they would take in a world struggle, realizing that they were being watched by the whole world as they made this decision. They were thus compelled to think of other things than the economic interests in which they had trusted almost entirely in the past.

These conditions also made them take life more seriously. Stopped from over-borrowing, both in public and in private, they were compelled to think of saving money as well as food and materials. A family which ordinarily had several automobiles for its different members now had to be content with one. Even if they had the money to buy automobiles or sugar or coal, they were often forced to realize that there were times when not even money could buy the things desired. The effect was something like a spoilt child losing his parents and being cut off from all of the things he had naturally supposed would come to him forever.

Moreover the stories of the sacrifices and the heroism of the peoples of Europe had large effect. Whether their particular nation declared war or not people were compelled to wake up to the meaning of war. The organization in their own homes of the work of such enterprises as the Red Cross, carried on at first by the British and French, later by the Americans, and still iater joined in by the nationals of the various countries themselves, had a widespread effect in awakening the people to the need for sacrifice and service.

Even the investment in Liberty Bonds has had a good effect in bringing about these closer relations and in emthasizing the lessons of thrift and responsibility of different Jeoples to help one another. The campaigns for the various war funds for the Allies were carried on in practically every 
Latin American country and yielded large results. Even little Santo Domingo gave some $\$ 85,000$ in one campaign to the Red Cross. The Young Men's Christian Association was able to raise large sums of money for its buildings in Montevideo and Rio de Janeiro, when the war was at its height. Thus a new spirit of giving was developed by the war. This new spirit will be favorable to a large support of those philanthropic projects which are for the development of the community. It is impressive to note the large number of individuals and organizations that are now beginning to engage in efforts to serve the people. The Temperance Society of Peru, which is composed of some of the leading men of the country, is doing a remarkable work. In Chile and Uruguay there are a large number of societies promoting educational and charitable work which are quite independent of the government. In Argentina there are large groups, ranging in their activities from discussions in university halls to socialistic meetings among workmen on the street corners, which indicate spiritual hunger and initiative.

The Child Welfare Congress is an illustration of this new spirit. The second such Congress held in June, 1919, in Montevideo was an outstanding success, and denotes a new day for the neglected child in South America. The discussions were frank and fundamental. It is impossible to imagine a physician saying in public a few years ago, as one did at this recent Congress, such words as the following:

"With relative frequency, and in the case of women who are neither ignorant nor poverty-stricken, I have been able to observe another cause of the abandonment of the child, something comparable to that which has been the result of the barbarous violations of women by the soldiers and officers of the German army in Belgium and France. Seduced by individuals of a higher social class than their own, which fact drives away from their minds all thought of legal reparation-marriage or the legitimation of the child-or betrayed by specimens of that impudent class of young sports who abound, particularly in the country districts, and who keep account of their conquests with the same cold-bloodedness and pleasure that a hunter calculates the number of 
trophies fallen to his gun-these poor young mothers abandon their child in despair."

The most remarkable of all reform movements are the two which in the United States have led to additional amendments to our Constitution-Prohibition and Feminism. Leading statesmen of these Southern countries have recently given voice to utterances which clearly show that they recognize the probability that both these movements will grow very rapidly. An illustration of the eagerness of women to enter into a larger life is found in the recent organization of a Young Women's Christian Association in Rio de Janeiro. Within one year it had 1,200 members.

There is an encouraging demand for light on spiritual questions. A course of lectures, which proved to be most popular recently in Buenos Aires, was given on Emerson and the significance of the Puritan and Unitarian movements in New England. The professor who gave these is profoundly concerned for his country as he says it makes no difference how far Argentina may advance materially, unless she finds a spirit-basis for her development, she cannot become a strong nation. He has been considering recently the organization of a conference on religion, with representatives from all the faiths of Argentina, to face up to this question, which he says is the most important now before his people.

Leaders in various countries also realize more deeply than before the necessity of practical and moral education for their children, and so impressed are they by the work of the North American mission schools that they are anxious to have the number increased. There is scarcely one of these schools in all Latin America that is not greatly overcrowded. The President of Paraguay, in discussing education with a group of North American missionaries who recently went to Asunción to plan for a new station, was so eager to cooperate, that he offered public lands for an agricultural school, and mentioned an experimental station, already begun, which could be turned over, equipment and all. He also promised his own children and those of the most prominent families as pupils. A most remarkable proposition was 
made recently to North American missionaries by one of the states of Brazil which offered them the free use of a well equipped agricultural school, with some I0,000 acres of land, agreeing to back the school for a period of fifty years, if the mission would provide the leaders in the teaching force. Moreover, the management was to have entire freedom in the matter of religious instruction. The Government of Brazil has selected a former teacher in one of the mission schools there to head a modern school of domestic science and paid her expenses to the United States to secure seven other young women teachers, specifying that they, like herself, should have the missionary spirit.

Many prominent Latin Americans claim that the Roman Catholic Church has lost prestige in South America because of the general recognition that the Roman hierarchy in practically all of these countries as well as in Europe favored Germany. The following words of Señor Vildosola, Editor of El Mercurio of Santiago, are generally applicable to other Latin American countries :

"Perhaps the most of those who in Chile are still friendly to the German cause are to be found among the clergy and the militant Catholics, although indeed they are not the more cultured and better informed. At the beginning of the war many members of the Chilean clergy suffered the same perturbation of judgment as that in which the Spanish clergy still remains; they believed that in this war the German Empire was an instrument of Providence to chastise France for having expelled the religious orders."

F. B. Luquiers, writing in The Century, refers to the same fact, as follows:

"The last common factor is very hard for us to understand, for there is nothing similar in the United States. I refer to the pro-German influence of the Latin American clergy. The attitude of the church in Latin American countries is perhaps to be explained by the fact that a majority of the priests are merely following the lead of Spain, for a tendency to look to Spain in matters of religion is the single 
exception to the rule that France is Latin America's counselor in all things material. It is very possible, in other words, that the first cause of the pro-Germanism of the Latin American clergy is to be found in the Napoleonic invasion of Spain more than a hundred years ago. In any case, it is certain that the lowest classes in Latin America, who feel no love for France, because they have no artistic impulses, and who do not abhor anything except starvation, have been easily pro-Germanized by their clerical advisers."

A radical writer in The Review of Philosophy, Culture, Science and Education of Buenos Aires takes advantage of the situation to say the following:

"And that which is even a greater anachronism, that which reveals the absolute lack of moral value in religion-since being religious does not signify being a lover of justiceis the fact that has been proved all over the world, and that is the sympathy of the Catholics for Germany, and the established principle that everyone under clerical influence is also a Germanophile. This is an aberration, an absurdity, an inadmissible incongruity,-inadmissible but nevertheless real. And the Spanish people, dominated by a retrograde and rancid clergy, is that which has struck the highest note in this matter, reaching extremes of tolerance for the Kaiser that is truly inexplicable."

This spirit of revolt against religion and society, as already pointed out, is growing. A number of ultra-socialistic, anarchistic and Bolshevist periodicals are now being published in Argentina, Brazil, Mexico and other countries. We must remember that this seed falls in prepared soil. The laboring classes have been greatly abused and controlled by superstitions and they will not stop at any extreme when they find that they have the power, unless Christian leadership sanely guides these movements among the laborers. The Catholic Church in Buenos Aires has recently assigned some of its priests to join the street meetings of the laborers and counteract the influence of the agitators. "Evangelical Christianity is all that can save Chile from a bloody revolu- 
tion," said a student of social affairs not long ago. In Mexico evangelical ministers, many of whom have taken a prominent part in the recent revolution, have already had a quieting influence on such agitation.

The writer recently addressed a questionnaire concerning the new conditions of education and religion in their countries to a number of Latin Americans. The following are some answers:

"Applied Christianity must be made a factor in national, political and social thought."

"The church must be put to work. Make it a business and men will care for it. Its activities will help to save it in this era of industrial iconoclasm. There is no medium like the Christian religion for the overcoming of prejudice. Racial, class and linguistic barriers are set aside and the political honesty of Wilson wins response from the sensitive Latins. It is self-evident that we must have this international moral rapprochement."

"The religious organization must be no less democratized than the political organization of human society."

"On every hand there is a clamor for a higher type of Christianity. Most men shrink from the mere thought of religion in forms or in creedal symbols or theological terms. The average man is repelled by conversations in which there is frequent reference to the church as the representative of Jesus Christ. There exists in the popular mind a clear distinction between the Christianity of Jesus and that of the ecclesiastics. The robust and virile type of discipleship is commended. For the man in the street contemplative Christianity has been largely sacrificed to the more practical type. Service is more important than services. Tolerance is as necessary as conviction."

There is pretty universal testimony that all the religious work must for the best results tend toward educational methods. As to education, it must recognize:

"That science is not necessarily benign unless informed by humane ideals-efficiency is not an end in itself-Liberty 
is. That the State should exist for persons, not persons for the State. That if strong national government tends to molestation of one's neighbors, anarchy, of the peaceful type (the extreme of individualism), is preferable."

"That real education en masse is impossible, just as character building en masse is likewise impossible. We need to teach and practice the privilege of the trained individual to interpret the duty and destiny of others to them, by unanswerable example."

"The urgent necessity of an educational system organized to use public funds in public education for the training of public-spirited citizens, competent and eager to render service. This, of course, involves academic and practical training, but this should be made subordinate to the prime goal of public service as distinguished from private gain. There must be a reorganization of courses of study and of general school activities with this in view. The educational system is in danger of developing along two lines, inconsistent with the general principle suggested above: first, an exceedingly narrow, superficial and excessive nationalism, and second, a selfish and narrow vocational training not designed to cultivate public spirit."

"All educational factors must be so organized as to train for world citizenship. Public sentiment must be educated to frown upon and refuse to tolerate the exploitation of the people in industrial, social or political fields; or jingoistic activities; or narrow, selfish nationalism."

Educators and religious leaders, some correspondents say, must with renewed vigor and from the modern viewpoint, show the falsity of the materialistic and economic theories of life. By new methods the people must be shown that strong nationality can only be developed through love and service and sacrifice. The spiritual leader must find new ways of identifying himself with the social, philanthropic organizations that are seeking outside of the church to do the same things that he is seeking to do in the church. He must realize that the church itself, as long as it is composed of human beings, is not a perfect organization, that besides there are many honest, spiritually minded people outside the 
church who are doing much for the Kingdom. He must seek fellowship with these men and work shoulder to shoulder with them. Rightly guiding the rising spirit of nationalism is mentioned as an important task. Ricardo Rojas defines nationalism as patriotism which has as its territorial and political base the nation. Its elements are solidarity, the consciousness of tradition and of language. $\mathrm{He}$ regards as "active factors of national dissolution Jewish schools where lessons are given in Hebrew, or colleges of religious congregations, Protestant establishments and German and Italian educational institutions which obey foreign governments." Discouragingly he describes a growing "cosmopolitanism in men and ideas, the dissolution of the old moral nuclei, indifference concerning the public business, and increasing forgetfulness of traditions, the popular corruption of language, ignorance of our own territory, lack of national solidarity, anxiety for riches without scruple, the worship of the most ignoble hierarchies, the disdain of higher accomplishments, the lack of passion in struggle, the lowering of suffrage, superstitious regard for exotic names, and blasting individualism and depreciation of ideals." The school is for Rojas the protector of nationalism, "as the church confronts a crisis and the family is not yet a powerful factor." The spiritual leader should guide this nationalism in sane channels and lead it into internationalism, showing that Christianity needs the peculiar emphasis of Latin America and North America, the Orient and of all peoples to make it a perfect whole.

It seems well to close these quotations with a letter just received from Dr. José Ingenieros of Buenos Aires, well known author and critic, which reveals both the difficult social problem and the most unfortunate reaction that has in the last few months set in against the United States, especially in Argentina, where commercial difficulties have colored all our relations. He writes:

"The religious and moral problem is today subordinated in all parts of the world to the social problem; until the iniquitous action of capital is done away with, it is impossible to look for justice and the solidarity of the people. 
LATIN AMERICA AND THE WORLD WAR 263

"We who believed three years ago in the famous propositions of Wilson are now undeceived in face of the immoral avarice of the Allied governments; the peace of Versailles has been simply a business arrangement, carried out with the spirit of commercialism.

"The industrial reconstruction of the world cannot be carried forward under the same economic principles that ruled before the war; in order that the producing classes give themselves to work it will be necessary to emancipate them from the parasitism of the unproductive classes. It seems to me that this is today the only problem that interests humanity: the suppressing of the parasites of work. Until this is done, with all good faith, the world will continue in civil war. Peace will only come with the triumph of justice.

"I know that these ideas are somewhat radical, but I have much faith in them, and I believe that they interpret historically the social reality. On the other hand I consider that the past economic régime has contributed to lowering the morality of men, placing the desire to enrich themselves above all ideals of moral perfection. As a consequence we ought to expect the greatest benefits from those ideas which tend to eliminate from society speculators, jugglers in finance, and parasites of all classes.

"In this city all of the churches, either by conviction or on account of fear, take the side of injustice and social parasitism; the progressive part of the youth and of the people themselves do not take any interest in the churches, being convinced that they are instruments of the past against the future.

"It has seemed to me well to give these ideas to you. Here everything North American is looked upon with doubt because it is believed that the only object is commercial conquest and capitalistic exploitation of South America. In order to rectify this belief it will be necessary to show an active sympathy for the new social ideas which are agitating all classes of people."

Notwithstanding Dr. Ingenieros' words, the following from one who travels all over South America and comes 
into contact especially with the cultured classes, should be given due consideration:

"With the present spiritual unrest, that signifies a deep longing for something morally and spiritually better, and with the United States standing today beside France in the affections of the South American peoples, one longs to see every North American agency that can, make a genuine contribution to the moral and spiritual progress of South America, give itself whole-heartedly to this opportunity. No such time has existed since the days following the gaining of their political independence."

\section{SOME DANGERS GROWING OUT OF THE WORLD WAR}

One of the first dangers to world peace to be found in Latin America would seem to be that involved in the trade war to which reference has already been made. This trade war will be liveliest as between England, the United States, Germany and Japan. It is not pleasant to refer to the bitter feeling often generated by trade rivalry between Americans and Englishmen in Latin America. Observers who live in South America, however, realize the keenness and seriousness of this rivalry.

In connection with foreign trade another evil should be pointed out, namely, a lowering of moral standards by those who engage in this keen commercial competition. Many report as having a baneful influence on North America's moral influence the practice of some merchants in the United States of deceiving Latin American customers by furnishing goods inferior to those promised, and in some instances practicing well planned deception. Many "war baby" export enterprises gave North American business a bad name in South America. The inexperience of many of our merchants-stupidity, Latin Americans call it-in export trade has been at the bottom of much misunderstanding. One result was to pile up, in the port of Buenos Aires alone, up to February, 1921, 45 million dollars of North American goods undelivered because of disputes and the financial crisis. 


\section{LATIN AMERICA AND THE WORLD WAR 265}

Since, owing to world conditions, it is the investors of the United States who are most free to extend their holdings and to make new investments in these countries of the South, there is danger of the domination of American financial interests in the affairs of these nations.

Already there have been upon the part of our investors several instances of successful interference in Latin American affairs, an outstanding illustration being the recent revolution in Costa Rica, where a progressive president was ousted largely through the influence of certain American financial interests who resented his refusal to grant concessions and special privileges to them. In Cuba, American investors control the economic life almost entirely, through their investments in sugar. If $\mathrm{Cuba}$ is not to become the American Ireland, careful consideration must be given to the obligation of the American people for the development of her spiritual and educational life.

Certain financial interests have united in the organization of a propaganda bureatu to discredit the Mexican Government in the United States. This organization may claim, as it has declared, that it is not in favor of armed intervention, which could only mean a war of invasion, but the effect of its propaganda is to persuade the American people that it is their Christian duty to take charge of the affairs of Mexico. A superficial view makes the average man, interested in "a moral clean-up" compare Mexico with Cuba and the Philippines, forgetting the vast differences not only in the size of the countries, but in the development of their nationality, and, above all, the fact that Mexico is against our intervening, whereas Cuba welcomed it very warmly since she needed help in her struggle for independence. The Philippines are composed of many separate peoples, speaking different languages, who have never yet developed a real national life or spirit. There rests upon the friends of Mexico a responsibility not only to make known all the facts in the case but also to take the part of their comparatively weak people when the strong materialistic and militaristic forces are united against it. If we fail to do this in all such cases, where because of our present outstanding power we have much to do with deciding the fate of the smaller nations, 
they will have little confidence in our protestations of friendship.

The third danger growing out of the war is the fear that the United States will use her military power developed in the World War for imperialistic purposes in Latin America. A former president of Colombia said recently in a public address: "We glory in the wonderful idealistic program of the United States as carried out in the World War. We admire all of her accomplishments. We pay tribute to her wonderful organization and the unselfishness with which she has thrown herself into the fight for democracy which is a fight for all of America. Yet we cannot fail to realize that the United States is building up a powerful war machine which might very easily be turned upon her weaker neighbors to the South."

Unfortunately there is enough talk of "America First" these days to explain why our southern neighbors should at times have such fears. As President Lowell says:

"Some Americans, while professing a faith in the right of all peoples to independence and self-government, are really imperialists at heart. They believe in the right and manifest destiny of the United States to expand by overrunning its weaker neighbors. They appeal to a spirit of patriotism that sees no object, holds no ideals, and acknowledges no rights or duties, but the national welfare and aggrandizement. In the name of that principle Germany sinned and fell. The ideas of these American imperialists are less grandiose, but at bottom they differ little from hers. It would be a calamity if we should have helped to overcome Germany only to be conquered by her theories and her errors.

"According to that view Central and South America are a game preserve, from which poachers are excluded, but where the proprietor may hunt as he pleases. Naturally the proprietor is anxious not only to keep away the poachers but to oppose game laws that would interfere with his own sport. With their professed principles about protecting the integrity and independence of small countries, the nations that have drawn up the Covenant of Paris can hardly con- 
sent to a claim of this kind. Nor ought we to demand it. A suspicion that this is the real meaning of the Monroe Doctrine is the specter that has prevented the great South American states from accepting the Doctrine. It has been the chief obstacle to mutual confidence and cordial relations with them, and the sooner it is definitely rejected the better."

A fourth danger in the present situation is the new emphasis on militarism and materialism, which in spite of all that has been said concerning new desire for spiritual life, has been felt by many Latin Americans. Many Latin American nations who have had practically no army or navy are now considering it imperative to spend the larger part of their national income on militarism.

The following is a summary of a reply to several questions addressed to a prominent lawyer and educator in Chile :

"First of all the war's lessons is that all nations and principally the small ones must be prepared for war on the Swiss model, so that every man and woman and factory would be a factor in war. The school must be the first step in war preparation. Rights must be supported by force, as force has proved, once more, that it is the best defender of rights. Had it not been for their perfect military organizations Holland and Switzerland would have been invaded. If international wars come to an end, they are going to be replaced by internal wars headed by the working classes against capitalism, and mankind will suffer more by these than by the former."

This feeling of materialism is further illustrated by the following published words of a prominent Argentine:

"The uselessness of the exaggerated religious spirit of our times is revealed by its own inefficiency. What use has religion been in the present world conflict? *** Religion has not been able to avert the war. On the field of battle peoples are being massacred by those of their own belief, and they march hand in hand with those whom they believed to be heretics but yesterday. *** But there must 
come out of it all, as a logical consequence of the struggle, the universal decadence of religious morality, and, with the strengthening of democracy, there will come the implantation of a human morality."

Summing up, the imfuence of the war in Latin America has been very marked in industrial, political and spiritual ways. It has brought hew economic independence, an awakening of labor, and a new attention to these countries from the rest of the world. A new friendship for the United States has been fostered and a new open-mindedness and spiritual hunger have been created. There have also been certain imminent dangers created-trade rivalries, imperialistic possibilities, and strengthening of materialism and militarism. A correspondent aptly puts the whole matter as follows:

"The war has generated a vortex of questions which have never presented themselves to a great many before the outbreak of hostilities. The employment of force, the doctrine of the universal brotherhood, the ancient problem of rampant evil, the baffling mystery of sacrifice, the inevitability of war, the relation of woman to nationhood, etc., have been forced upon them."

The Latin American nations have ceased to be children. Formerly they have been looked after by outside nations, their finances have been provided for them, their national resources exploited, their intellectual life dominated. The war has changed all this. Just as the child who has been protected by others comes to be thrown on his own resources and is forced to make his own choices, so these young nations are beginning to face life with new seriousness and new responsibilities. As with all young people this will not be an unmixed evil. They will yield to many temptations unless they have the strongest possible help from their matured friends. It is not only a fight for supremacy in the world of commerce that we shall see taking place in Latin America, but a fight for supremacy in the world of culture and morals. 
Sources of Further Information on Latin America and the World War

Ingenieros, José: Los Tiempos Nuevos.

Inman, Samuel G.: Intervention in Mexico, Social and Religious Conditions in South America.

KirkPatrick, F. A.: South America and the War.

LUGONES, LEOPOLDO: Mi Beligirancia,

Martin, Percy A.: Latin America and the War, World Peace Foundation.

South American Opinions of the Wa carnegie Endowment for International Peace.

The best material is found in the files of the following magazines: Inter-America, The South American, Pan American Bulletin, Hispanic American, Historic Review, Current History, La Nueva Democracia, La Reforma Social. 


\section{Chapter VIII}

\section{PROBLEMS OF TUE CARIBBEAN COUNTRIES}

Few North Americans realize how extensively and with what rapidity our "far-flung battle-line" is growing. Our conception of our native land is generally limited to the forty-eight states represented in our national congress. It is a positive shock therefore for the ordinary North American to travel through the various Caribbean countries, as I have during the last year, and come face to face with the predominance of the influence of the United States in these little Caribbean republics (so-called). This influence has increased gradually but very steadily. As the result of the Spanish-American War we came into complete possession of Porto Rico. While Cuba was turned back to her own people, by means of the Platt Amendment, we still maintain virtually a protectorate in that country and own outright a naval station at Guantanamo. The war with Spain showed the necessity of building the Panama Canal and the United States forced its control over the Isthmian territory -as President Roosevelt said: "I took Panama." * The Canal Zone became entirely ours, with the Panamanian Republic itself under our influence. In I9I 2 we sent marines into Nicaragua to restore order and since that time we have maintained a garrison of at least a hundred marines in the capital city, Managua.

In I9I 5, after one of the worst of Haiti's many disturbances, we landed marines on that island, directed new elections and proposed a treaty which gives us practical control of the country. A year later a revolution in Santo Domingo was the cause for our landing marines there and when the government then in power would not agree to the kind of a treaty that the United States desired, martial law was declared and Admiral Knapp was made Military Governor. 
Since that time the government of the Dominican Republic has been carried on by decrees of the Military Governor. In 1916 the United States government purchased for 25 million dollars the Virgin Islands in order that our strategic position in the West Indies might be still more secure.

The influence of the United States has also been extended over most of the other countries of this area by the new Caribbean policy begun during the Roosevelt administration and continued and developed during that of Taft and Wilson. This policy is marked by a tendency to force peace and order by establishing fiscal and police control, by denying recognition to revolutionary governments and by blocking the securing of financial aid from abroad. These means were used to restrain violence and irregularities and to maintain progress, as the United States understood that word. It amounted to the establishment of protectorates over these small, disturbed lands, although that term has been, as far as possible, avoided. In subjecting them to guardianship or tutelage, the aim was not to deprive them of their sovereignty or independence, but to extend needed help in insuring stability, solvency, sanitation, protection from foreign creditors and general welfare.

This altruism has not been altogether appreciated by the Caribbean countries. They seem to think they had rather be rowdy children in their own house than orderly children in that of someone else. On the other hand the United States believes that we have come to a time in the world's life when continued disorder cannot be allowed, both because of its dangers to the peace of the United States and to the equilibrium of all international relations, economic as well as political.

\section{STRATEGIC IMPORTANCE}

The two most important trade routes in the world are the Mediterranean and the Caribbean. The former has seen the greatest play of the world's forces of any body of water in the world up to the present time. The two great twin seas, the Gulf of Mexico and the Caribbean Sea, are destined pos- 
sibly to become more vital even than the Mediterranean in their effect upon the commerce and civilization of the world.

The strategic importance of the West Indies has been recognized by the political leaders of the United States ever since the beginning of the Republic. The story of our endeavors to secure the control of Cuba extends back to the beginning of the Nineteenth Century. President Madison in 1810 declared the deep interest of the United States. It was feared that when he became possessed of Florida, Great Britain would secure Cuba, but this did not come to pass. There was some sentiment in the United States in favor of its annexation and John Quincy Adams in I823 said: "In looking forward to the probable course of events * * * it seems scarcely possible to resist the conviction that the annexation of Cuba to the Federal Republic will be indispensable to the continuance and integrity of the Union itself." Jefferson said in I823: "Cuba alone seems to hold up a speck of war to us. Its possession by Great Britain would indeed be a calamity to us." He advocated procuring possession of it.

Mexico and Colombia determined to seize Cuba for defense if war continued with Spain, and in I825 the United States undertook to get Spain to acknowledge the independence of these colonies, and, in order that these attempts might not be thwarted, at the same time endeavored to induce Mexico and Colombia to withhold attack on Cuba.

The Cuban question was prominent in debate about sending delegates to Panama Congress in 1826. Sending of delegates would imply a change of attitude toward Cuba and Porto Rico, which the United States had said she wished to remain part of Spain.

The southern members of Congress were opposed to relations with the southern republics because they had adopted the principle of emancipation and their influence would jeopardize slavery in the United States. For the same reason they were opposed to the transfer of Cuba to any European country. Spain was assured of the help of the United States in case other nations should attack Cuba.

After the Mexican War the idea of natural expansion and "Manifest Destiny" took hold of the United States, 
and many bold schemes were advanced for securing Cuba and extending our territory southward.

With the same idea of strategy, President Grant proposed to the Senate the annexation of Santo Domingo at the bargain price of $\$ 1,500,000$. Among his arguments submitted to Congress were the following:

"The acquisition of Santo Domingo is desirable because of its geographical position. It commands the entrance to the Caribbean Sea and the Isthmus transit of commerce. It possesses the richest soil, the most capacious harbors, most salubrious climate and the most valuable products of the forests, mines and soil of all the West Indian Islands. Its possession by us will in a few years build up a coastwise commerce of immense magnitude, which will go far toward restoring to us our lost merchant marine. It will give to us these articles which we consume so largely and do not produce, thus equalizing our imports and exports. In case of foreign war it will give us command of all the islands referred to and thus prevent an enemy from ever possessing himself of rendezvous on our very coast. At present our coast trade on the Atlantic is cut by the Bahamas and Antilles. Twice we must, as it were, pass through foreign countries to get by sea from Georgia to the west coast of Florida.

"Santo Domingo, with a stable government under which her immense resources can be developed, will give remunerative wages for tens of thousands of laborers not now on the island. This labor will take advantage of every means of transportation to maintain the adjacent islands and seek the blessings of freedom and its sequence-each inhabitant receiving the reward of his own labor."

When the treaty was opposed by Sumner, Grant said: "If we abandon the project I now firmly believe that a free port will be negotiated for by European nations in the Bay of Samana."

In the same way the deciding argument that was said to weigh with President Wilson in the purchase of the Danish Islands was the report that Germany was ready to buy them, even in the midst of the World War. 
In the same way the United States has seen the importance of Central America, especially Panama and Nicaragua, and, since the discovery of gold in California when these two routes were used by American travelers, has kept a careful eye on these canal routes as being imperative for us to control.

\section{ECONOMIC REASONS}

In recent years the economic importance of the Caribbean countries has become increasingly evident. The land area, consisting of the West Indian Islands, the Guianas, Venezuela, Colombia, Central America and Mexico, has already an annual commerce of approximately $\$ 2,000,000,000$. And this is only the beginning of the producing power of this wonderful area. The area of the thirty islands and countries lying within or adjacent to the waters of the Caribbean and the Gulf of Mexico is about 2,000,000 square miles, its present population approximately $40,000,000$, its $1918 \mathrm{im}-$ ports $\$ 700,000,000$, and its exports $\$ 900,000,000$ in value.

The growth of trade between the United States and the land area fronting upon the Caribbean and Gulf of Mexico has been rapid, especially in recent years. It totalled in 1900 , $\$ 195,000,000$, in 1910, $\$ 392,000,000$, in 1919, $\$ 1,005,-$ 000,000 . The imports from the countries in question were in $1900, \$ 100,000,000$, in $1910, \$ 223,000,000$, in 1919 , $\$ 520,000,000$, and the exports to those countries and islands in $1900, \$ 95,000,000$, in 1910, $\$ 169,000,000$, and in 1919, $\$ 485,000,000$.

Not only is our trade with the countries in question growing rapidly, but the share which we supply of their imports is steadily increasing in practically all cases. The share supplied by the United States of the imports of Cuba, as shown by the official figures of that government, was in I9I $4,58 \%$, in $1918,76 \%$; of Santo Domingo in 1913, 62\%, in 1918, $93 \%$; of Haiti in $1913,59 \%$, in 1919, $90 \%$; of Mexico in I $913,48 \%$, in 1919, $85 \%$; of Colombia in $1913,28 \%$, in $1919,49 \%$; of Venezuela, in 1914, $43 \%$, in 1918, $50 \%$; of Costa Rica, in 1914, 53\%, in 1918,61\%; of Guatemala, in 1913, $50 \%$, in $1918,66 \%$; of Honduras, in $1914,79 \%$, in $1918,82 \%$; of Nicaragua, in $1914,62 \%$, in $1918,71 \%$; of 


\section{PROBLEMS OF THE CARIBBEAN COUNTRIES 275}

Panama in $1914,41 \%$, in $1918,87 \%$; of Salvador (which, while not fronting upon the Caribbean, is so closely associated with the other Central American countries as to justify its inclusion in this discussion), in $1914,41 \%$, in $1918,65 \%$.

These facts as to the producing power, present and prospective, of the land area touching the waters of the Caribbean and the Gulf of Mexico are especially important to the United States, both as to the present and to the future. All of this area just described-the islands of these tropical waters and the lands fronting upon it-produces, almost exclusively, tropical growths:-sugar, coffee, cacao, tobacco, fruits, nuts, sisal, cotton, rubber, balata, cabinet woods, dye woods, cocoanuts, and many other oil nuts and seeds, as well as many other articles which the temperate zone demands-must have, in fact. In exchange they must have certain temperate zone products, meats, breadstuffs, clothing, and manufactures of all kinds, for the manufacturing industries do not thrive in the tropics. As a consequence of this condition, the Caribbean countries must look to some part of the temperate zone as a market for their products and also as a market in which to buy their requirements of food and clothing and manufactures, and they naturally prefer to sell their goods on the nearest possible markets and to purchase their requirements in the nearest possible markets.

\section{CUBA}

We have already referred to the interest that the United States had in Cuba since the beginning of the Spanish-American struggle for liberty. After the Civil War the main object of our Cuban diplomacy was the extension of commercial relations with the island and the protection of American interests. The "Ten Years' War" in Cuba, from I868 to 1878 , was characterized by great cruelty, destruction of property, and irregular methods of warfare, and imposed grave responsibilities upon the United States. President Grant seriously considered, and even threatened, intervention, and intervention at this time would probably have meant annexation; but such action was postponed, and peace was finally restored as a result of the exhaustion of both parties 
and the promise of definite reforms by Spain. The promised reforms were not carried out in good faith; the old policy of exploitation was continued.

Finally in February, 1895, the last insurrection against Spanish rule began, and soon developed the same features as the "Ten Years' War." Both sides were guilty of outrages, and conditions became so distressing that the United States was led to intervene in 1898 and secure Cuba's independence.

Unquestionably one of the finest chapters in United States history is that dealing with the liberation and modernizing of Cuba. While we may frankly admit that we have had a selfish interest in Cuba, because of its strategic position, yet this does not take away the glory of the service rendered that country. For no one who knows the North American people can fail to appreciate their altruistic motives in freeing oppressed neighbors. Unfortunately the rest of the world has not however generally appreciated this service, often alleging that, while partial political liberty was granted, commercial advantages, the real thing desired, have not been attained and Cuba has been abused.

There is necessity for North Americans, while priding themselves on their service to Cuba, to look carefully to the use of our influence over the island, that it may be for her good and not for our self-aggrandizement. By means of the Platt Amendment, we hold large power over the political life of Cuba. This has been generally a blessing, but it could easily become a power to help the few exploit the many. As regards economic life, Cuba is held in the hollow of our hand. Her two great crops of sugar and tobacco are so vital to us that we have come to control them. Since she produces so few things and sells them practically all to us, she must depend on us not only for manufactured goods but very largely for foodstuffs also. The extensive development of an absentee landlord system could easily produce an American Ireland for the United States. To prevent this we must bend our energies to help Cuba develop the education of her people so that strong character will work out the problems of self-government, diversified crops, honesty in administration,--and personal sacrifice for national good. 
The key to the relationships between the United States and Cuba is found in the famous "Platt Amendment," which, at the urgency of the United States government, was adopted by the Cuban Convention as follows:

“(I) That the Government of Cuba shall never enter into any treaty or other compact with any foreign Power or Powers which will impair or tend to impair the independence of Cuba, nor in any manner authorize or permit any foreign power or powers to obtain by colonization or for military or naval purposes, or otherwise, lodgment in or control over any portion of said island.

"(2) That said Government shall not assume or contract any public debt, to pay the interest upon which and to make reasonable sinking-fund provision for the ultimate discharge of which, the ordinary revenues of the island, after defraying the current expenses of government, shall be inadequate.

"(3) That the Government of Cuba consents that the United States may exercise the right to intervene for the preservation of Cuban independence, the maintenance of a government adequate for the protection of life, property, and individual liberty, for discharging the obligations with respect to Cuba imposed by the Treaty of Paris on the United States, now to be assumed and undertaken by the Government of Cuba.

"(4) That all acts of the United States in Cuba during its military occupation thereof are ratified and validated, and all lawful rights acquired thereunder shall be maintained and protected.

"(5) That the Government of Cuba will execute, and as far as necessary extend, the plans already devised or other plans to be mutually agreed upon, for the sanitation of the cities of the island, to the end that a recurrence of epidemic and infectious diseases may be prevented, thereby assuring protection to the people and commerce of Cuba, as well as to the commerce of the southern ports of the United States and the people residing therein.

"(6) That the Isle of Pines shall be omitted from the proposed constitutional boundaries of Cuba, the title thereto left to future adjustment by treaty. 
"(7) That to enable the United States to maintain the independence of $\mathrm{Cuba}$, and to protect the people thereof, as well as for its own defence, the Government of Cuba will sell or lease to the United States lands necessary for coaling or naval stations at certain specified points to be agreed upon with the President of the United States.

"(8) That by way of further assurance the Government of Cuba will embody the foregoing provisions in a permanent treaty with the United States."

\section{PANAMA}

The digging of a canal across Panama was first planned by the Spaniards in early colonial history. The United States early entered into discussion of the project with Colombia and Great Britain. The Clayton-Bulwer convention of 1850 provided for a canal constructed by private capital and under the political control of Great Britain and the United States, and such other powers as might unite with them in guaranteeing its complete neutralization. The organization of a French company by De Lesseps, and the prospect of the speedy construction of a canal at Panama under French auspices, led to the change of policy announced by President Hayes, when he deciared in I 880 that any canal that might be constructed between the Atlantic and Pacific oceans should be under American control; and that the line of such canal should be considered "a part of the coast line of the United States."

But Great Britain refused to waive her rights provided by treaty and Secretary Olney declared in 1896 that the only way to modify the stipulations of 1850 was through a direct appeal to Great Britain for a reconsideration of the whole matter. This was done by Secretary Hay, who undertook, in 1899 , to negotiate a new arrangement with Great Britain, resulting in the Hay-Pauncefote treaty. After many struggles and changes this treaty was ratified December I6, I901. The new treaty abrogated in express terms the ClaytonBulwer agreement and provided that the United States might construct a canal under its own auspices and under its exclusive management. 


\section{PROBLEMS OF THE CARIBBEAN COUNTRIES 279}

Senator Hanna was largely responsible for the selection of the Panama route over Nicaragua. After an investigation of the affairs of the Panama Canal Company, AttorneyGeneral Knox reported that it could give a clear title. Negotiations between Secretary Hay and Mr. Herran, the Colombian chargé d'affaires, resulted, after considerable delay, in the signature, January 22, 1903, of the Hay-Herran convention, by the terms of which the United States agreed to pay Colombia Io million dollars cash and an annuity of 250 thousand dollars for the lease of a strip of land six miles wide across the isthmus. The United States was so anxious for the immediate building of the canal that Colombia was warned that the treaty must be passed "without amendment whatever," and that rejection or delay might seriously compromise the friendly feelings between the two countries.

The Colombian Congress met in extra session June 20 mainly for the purpose of considering this treaty. When the vote was finally taken August I 2 the treaty was rejected by the unanimous vote of all the senators present. President Roosevelt later declared that this action was due to the "anti-social spirit" of Colombia and to the cupidity of the government leaders, who proposed to wait until they could confiscate the 40 million dollars worth of property belonging to the French company and then sell it to the United States. However, Mr. Beaupré, the American Minister, repeatedly warned Secretary Hay that there was a "tremendous tide of public opinion against the canal treaty," which even the Colombian government could not ignore. The people of Colombia felt that Panama was their greatest asset. They knew perfectly well that, in spite of threats to the contrary, President Roosevelt was determined not to adopt the alternative of the Spooner amendment and go to Nicaragua; consequently they opposed the treaty with the expectation that they could get better terms, and particularly that they might reserve a fuller measure of sovereignty over the isthmus. The difficulty in securing the assent of the Colombian Senate to a treaty arranged by the Department of Foreign Relations should be well understood by those North Americans who remember the opposition of their own Senate to almost every treaty prepared by the Executive Department. 
The people of Panama considered that the failure of Colombia to sign the treaty was a sacrifice of their interests. Dr. Manuel Amador visited the United States and had conference with William Nelson Cromwell and with Secretary Hay concerning the advisability of Panama's revolting. The latter was of course guarded in his replies, but outlined what he considered the rights and duties of the United States under the treaty of 1846 . Dr. Amador was greatly encouraged at this time by the sudden arrival in New York of Philippe Bunau-Varilla, the former chief engineer of the French company, who entered with enthusiasm into the revolutionary project.

Soon after Amador returned to Panama the gun-boat Nashville arrived off Colon. The Boston, Dixie and Atlanta had also received orders to proceed "within easy distance of the isthmus, in the event of need arising." Two days after the Colombian Congress had adjourned orders were cabled to the American naval commanders to keep the transit open and to "prevent the landing of any armed force with hostile intent, either government or insurgent, at any point within 50 miles of Panama." It can hardly be denied that this was creating a situation very favorable to revolution.

The revolutionists were slow in taking advantage of their opportunities, seemingly causing impatience in Washington. At 3:40 P.M., November 3, the following dispatch was sent to the American consuls at Panama and Colon: "Uprising on Isthmus reported. Keep Department promptly and fully informed. Loomis, Acting." At 8:I5 P.M. a reply was received from Consul Ehrman at Panama: "No uprising yet. Reported will be in the night. Situation is critical." At 9:50 P.M. a second dispatch was received from the same source: "Uprising occurred to-night, 6; no bloodshed. Army and Navy officials taken prisoners. Government will be organized to-night."

The few Colombian troops on the Isthmus were reembarked after their officers had received a generous bribe, and the marines, landed from the United States gun-boat Nashville, maintained order. Just four days later the United States government recognized the Republic of Panama, and a week later the Minister of the Panama Republic, being in 


\section{PROBLEMS OF THE CARIBBEAN COUNTRIES 281}

Washington when appointed, was received by President Roosevelt. This unprecedented haste tended to give color to the rumors that the whole affair had been prearranged.

An interesting discussion of the Panama question appeared in the Review of Reviews for November, 1903. Dr. Albert Shaw, a close personal friend of President Roosevelt, published an article entitled, "What If Panama Should Revolt?" and outlined with remarkable prophetic insight what actually took place later. It transpired afterward that this editorial had been inspired by the following letter which he had received from the President, dated October Ioth: "My dear Dr. Shaw : I enclose you, purely for your own information, a copy of a letter from our Minister to Colombia. I think it might interest you to see that there was absolutely not the slightest chance of securing by treaty any more than we endeavored to secure. The alternatives were to go to Nicaragua, against the advice of the great majority of competent engineers-some of the most competent saying that we had better have no canal at any time than go thereor else to take the territory by force without any attempt at getting a treaty. I cast aside the proposition at this time to foment the secession of Panama. Whatever other governments can do, the United States can not go into the securing, by such underhand means, the cession. Privately, I freely say to you that I should be delighted if Panama were an independent state, or if it made itself so at this moment; but for me to say so publicly would amount to an instigation of a revolt and therefore I cannot say it."

President Roosevelt justified the course of the administration by showing the ingratitude of Colombia for the work of the United States in maintaining order on the isthmus for over fifty years under the treaty of I 846 , and her utter inability to control the situation and prevent riot and revolution. In a special message to Congress on January 4, 1904, the President held that Colombia was not entitled "to bar the transit of the world's traffic across the isthmus," and that the intervention of the United States was justified(I) by our treaty rights, (2) by our national interests, and (3) by the interests of collective civilization.

The majority of the people of the United States, as well 
as those of Latin America, have undoubtedly felt that all was not right with the way the Panama Canal Zone was secured. So, after an agitation of many years, a treaty with Colombia, which had been held in the Foreign Relations Committee since I9I4, was finally passed by the United States Senate, April 19, I92I, which agrees to pay Colombia the sum of 25 million dollars for the Panama strip, said sum to be invested in certain public works. Thus, let us hope, the world may see that, whether or not there was justification for taking by high-handed means a piece of land for the service of humanity, at least we are ready to pay a money value to the original owners for that which was expropriated. Without doing so the United States could never have stood right in the minds of her Hispanic American neighbors. The writer was in South America when the treaty was passed and was able to observe the universal satisfaction with which the report of the Senate's action was received.

\section{SANTO DOMINGO}

It is in Santo Domingo that the United States Government has taken more complete control of the government than in any other Caribbean country. Reference has already been made to the request of the people of Santo Domingo for annexation to the United States and President Grant's efforts toward the same end. In I904 relations with Santo Domingo again became critical, because of the demands of European creditors. Protocols for the settlement of debts had been signed with Germany, Spain and Italy and these governments were about to make effective by force the collection of these debts. The government of Santo Domingo appealed to the United States for assistance and a plan was worked out whereby North American agents were to take charge of the customs and finances of the country. In spite of the refusal of the United States Senate to approve the plan, President Roosevelt, as Commander of the Navy, put it into effect. Two years later the Senate, seeing that the matter was being carried out anyway, decided that it would be better to make it formal and a treaty was signed by the 
two governments authorizing the arrangements. The results were most satisfactory in that the interest on the debts, which had been funded together, was paid and a fixed sinking fund was augmented annually by which the principal was to be covered.

It was hoped that this arrangement would also entirely do away with revolutionary movements; the theory being that revolutions all revolved around the custom houses, which held the country's revenues. These hopes were not to be realized for disturbances broke out to such an extent in May of 1916 , that some I,800 United States marines were landed in two divisions. Those of the north fought their way across the island until they joined their companions at the capital in the south, who had been able to take charge with less difficulty. The United States Naval authorities came into conflict with the Dominican civil authorities and, in order to break the deadlock, Rear-Admiral Knapp declared the country under military rule of the United States in a proclamation dated November 29, 1916. The following is a part of the proclamation:

"Whereas a treaty was concluded between the United States and the Republic of Santo Domingo on February 8, 1907, article 3 of which reads:

"III. Until the Dominican Republic has paid the whole amount of the bonds of the debt, its public debt shall not be increased, except by previous agreement between the Dominican Government and the United States. A like agreement shall be necessary to modify the import duties, it being an indispensable condition for the modification of such duties that the Dominican Executive demonstrate and that the President of the United States recognize that, on the basis of exportations and importations to the like amount and the like character during the two years preceding that in which it is desired to make such modification, the total net customs receipts would at such altered rates of duties have been for each of such two years in excess of the sum of $\$ 2,000,000$ United States gold.'

"Whereas the government of Santo Domingo has violated article 3 on more than one occasion and 
"Whereas the Government of Santo Domingo has from time to time explained the violation by the necessity of incurring expenses incident to the repression of revolution, and

"Whereas the United States Government, with great forbearance and a friendly desire to enable Santo Domingo to maintain domestic tranquillity and to observe the terms of the aforesaid treaty, has urged upon the Government of Santo Domingo certain necessary measures which that Government has been unwilling or unable to adopt, and

"Whereas the Government of the United States has determined that the time has come to take measures to assure the observance of the aforesaid treaty by the Santo Domingan Republic and to maintain the domestic tranquillity in the said Republic of Santo Domingo necessary thereto.

"Now, therefore, I, H. S. Knapp, Captain of United States Navy, Commander of the cruiser force of the United States Atlantic fleet and the armed forces of the United States stationed in various places within the territory of the Republic of Santo Domingo, acting under the authority and by the direction of the Government of the United States, declare and announce to all concerned that the Republic of Santo Domingo is hereby placed in a state of military occupancy by the forces under my command, is made subject to military government and to the exercise of military law applicable to such occupation.

"The military occupation is undertaken with no immediate or ulterior object of destroying the sovereignty of the $\mathrm{Re}$ public of Santo Domingo, but, on the contrary, is designed to give aid to that country in returning to a condition of internal order that will enable it to observe the terms of the treaty aforesaid and the obligations resting upon it as one of the family of nations."

There follow five other paragraphs, stating that the courts will not be disturbed, revenues will be paid by the Receiver to the military government (to be held in trust for the Republic), calling on all to cooperate in restoring order, and stating that the United States would act under military law governing their conduct, all signed by Commander H. S. 
Knapp, on the U. S. S. Olympia, flagship, November 29, I9I6.

Since that date the government of Santo Domingo has been absolutely in the hands of the military forces of the United States. How absolutely one is not prepared to appreciate until he goes to the country. A Rear-Admiral of the United States Navy is the President of the Republic and his cabinet is made up of officers of the United States Marine Corps. There is not a semblance of a Dominican legislative body. The following is the Executive Order of December 26, 1916, suspending the Congress:

"I. That the sessions of the Dominican Congress are' suspended until after elections shall have been ordered and held to fill vacancies now existing.

"2. That the senators and deputies whose terms have not expired are likewise expelled from office until the full Congress shall have been called into session, and that their emoluments shall cease."

The laws are proclamations by the military authorities and are enforced by the 1,500 marines in the country and the national gendarmerie, made up of natives officered by enlisted men of the Marine Corps.

These American military forces, many of whom are facing an entirely new experience with honest purpose of helping the people, have a difficult task before them. Since Columbus was imprisoned in the fort of her capital city, the history of Santo Domingo has been a sad one. Nowhere is the rise, decline and fall of Spanish colonial power so vividly exemplified as in Santo Domingo with its history teeming with great names and with deeds now bloody, now paltry, with conquest and quarrels, discovery and piracy, with exploits and exploitation, slavery and revolution. Nowhere was there builded into the foundations of the civil structure that love of home, of popular education and of equality lefore the law that have given to the United States whatever of stability its institutions may boast. Religious zeal was there, but it was exotic and misguided, seeking its finest expression in a monasticism that contributed little more than 
faint intermittent protests against the general decay of popular morals caused largely by the brutal exploiting of subject peoples in the general greed for riches without labor.

There is an utter absence of all the facilities and forces that we associate with modern civilization. The capital has no street cars, no sewers, water or telephone systems, only a few private electric light plants and no building ever erected entirely for school purposes. Illiteracy on the island is calculated at 90 to 95 per cent. of persons over ten years of age. Many country people have no sense of numbers above five. There are practically no roads, and the northern and southern parts of the island are like two different countries. Venereal diseases, hookworm, malaria and tuberculosis have run riot without anyone knowing how to treat them. These things must be taken into consideration when we examine the accomplishments of the forces of American occupation.

In the summer of I9I9 I visited Santo Domingo to make a survey of social conditions and suggest a united program of service which could be undertaken to help in the island's development. Practically every person I asked as to what the people particularly needed, replied, "Everything." If I suggested this or that or the other institution or activity, the reply was "Yes, anything you can do for these people will be worth while. Don't be afraid of duplicating or doing too much. That would be impossible."

A program was drawn up which was approved by the principal Dominican and North American residents of the capital. This program is now being put into operation through a newly organized Board for Christian Work in Santo Domingo, which is beginning a system of industrial schools, hospitals, community centers and institutional churches. One of the most notable things about this work is that it is to be entirely non-sectarian, the use of denominational names as found in the United States is to be eliminated and the workers are to be employed because of their ability to render the particular service needed, without reference to their ecclesiastical connections.

As to the good results of the military government, they are seen in the elimination of revolution-the bane of the 
country for a century-the building of roads and port works, gradual paying off of the national debt, improved sanitary conditions, providing stable conditions for business and the improvement of the educational system.

It must be recognized that these improvements are made at the expense of much bad feeling between the governors and the governed. A military government is not designed to develop a people into self-expression or prepare them for self-government. In the first place, there is too much government. Martial law always means regulation of every detail of life. People cannot meet in public gatherings to discuss their problems. The newspapers cannot discuss political questions, and criticisms of the military government are not to be thought of. Individuals talk mostly in whispers if they answer adversely your inquiries as to how they like the present order. In the second place, a foreign military government conducted largely by people who cannot speak the language of the people and who have no idea of their history or national psychology must necessarily be an unjust government. Some of the American officials do their work in as fine a spirit as any missionary who ever went to serve on a foreign mission station. But this does not keep them from making great mistakes when they arbitrarily determine problems of taxation, education and economic and social life. The United States Navy has not had sufficient experience in colonization to have built up a body of experts in such matters. Officers are changed too often to acquire experience, and enlisted men are too anxious to get home to take any interest in the people.

In the matter of education a wonderful showing has been made in the primary schools, which have grown from an enrollment of some 30,000 four years ago to 120,000 at present, due to the efforts of Colonel Lane, of the United States Marine Corps, the Minister of Education. Unfortunately Colonel Lane has recently left the island, illustrating the too-prevailing custom of changing officials just when they are beginning to get into these problems. His efforts were centered upon combating illiteracy. There are no jermanent educational foundations laid for building up an adequate teaching force or training the children along in- 
dustrial lines, which is the great need of the country. Higher education is almost wholly lacking and the provision of former governments to send a number of students to foreign countries has been discontinued by the military government because of these students making certain political problems.

The governors and the governed live entirely apart from each other with practically no means of intercourse. While a few of the Dominicans have been employed to assist the Americans, these have thus largely cut themselves off from their own people. The Americans generally remain to themselves and the Dominicans do likewise, if for no other reason than the simple one that $99 \%$ of each party is unfamiliar with the language of the other.

This was brought home to me by a visit to Señor Federico Garcia Godoy, one of the most noted literary men in Latin America. American Army men in La Vega, his home, did not even know where he lived. When he found out that I was not, as he supposed all American visitors were, a commercial traveler, and that I had read his books and knew some of his friends in the literary world of Latin America, he was simply overjoyed. To meet an American who could talk of something in his world and not simply commercial topics was a new experience for him. Thus all the time I was meeting choice spirits among both Dominicans and Americans who knew nothing of one another. The situation which shuts out entirely from the molding of the national life some of these splendid Dominicans who are well known for their ability in other parts of the world, is an impossible situation.

The Dominicans recognize that they have made a mess of governing themselves during the hundred years they have tried it. They are not unmindful of the benefits that have come from peace and increased prosperity enjoyed under American rule. Few ever expect to be entirely out from under American influence. Strange to say, I found most of them preferring their present situation to that of Haiti. They seem to reason about as follows: "The present military government is temporary. Public opinion of the world will not allow it to continue once the situation here becomes 
understood by the outside world. If we should sign a treaty like that signed by Haiti, then we ourselves should be to blame for the loss of our sovereignty. Give us a treaty like the arrangement with Cuba. Then the United States can protect its commercial interests and help us to restore order if we return to political turmoil. But if we are good, then we can direct our own affairs."

The greatest difficulty with such a situation as the present, however, is that the people are not prepared for self-government. The Dominicans have no responsibility placed upon them. They have no incentive toward progress except material prosperity. More of their children may be taught to read and write and more may enjoy automobile rides on good roads, but the present military government by its very nature cannot give itself to the development of the nobler things of life. Indeed in the interior of the country development is still held back by serious disorder, which in five years the marines have been unable to suppress.

The continuance of a severe press censorship probably does more to cause dissatisfaction than anything else. Not long ago three Dominican newspaper men were arrested for criticising the military government and their cases were transferred from the provost court to a military court martial. This news leaked out and was cabled all over Latin America, causing intense indignation. Telegrams from press organizations in many different countries reached President Wilson, asking him to spare the lives of these men, which was done. Two of these men were authors well known wherever the Spanish language is read. One of them, who has formed a part of the literary circles of Paris, London and New York, was a delegate to the Third Pan American Conference and heard Mr. Root make his famous declaration, "We wish for no victories but those of peace, for no territory except our own, for no sovereignty except over ourselves, we neither claim, nor desire any rights, privileges or powers we do not freely concede to every American republic."

Americans who not only believe that Mr. Root here truly represented his people but who are also anxious that the rest of the world believe this will rejoice in the announcement 
issued just before the close of the Wilson Administration, that the marines were to be withdrawn from Santo Domingo, a commission of Dominicans being appointed to work out with the North American government the relationships that should exist between the two governments. It will not be an easy problem to protect the Dominican people from their own worse selves and to aid them in building a government that will assure peace and progress and the exercising of that sovereignty to which they are, by the law of nations, entitled.

\section{HAITI}

If the visitor to Santo Domingo has come to believe that he is in the most backward of all the world's districts, he is soon led to change his mind on arriving in Haiti. In the interior one is constantly reminded of the heart of Africa, with the latter sometimes having the place of preference. While the country is only half as large as Santo Domingo, it has more than three times the population, about two and a half million, making it one of the most thickly populated districts in the western hemisphere. It is the black man's paradise. In I 795 Spain transferred the island to France and thus it became the only country in Latin America where French is spoken. The country people speak a patois which is a mixture of French, English and their native tribal tongue. Not over five per cent. of the people are able to read and write.

Haiti, like Santo Domingo, is one of the richest countries on earth and, like her neighbor also, has had one of the most turbulent histories. Of the twenty-five presidents from I8I6 to I903, three were assassinated, one died from wounds received in his palace, one committed suicide, fifteen were driven out by revolution, three died in office and one lived out his term and died a natural death in his own country.

As a result of one of the worst of these revolutions Admiral Caperton, on July 29, I9I5, landed marines. A few days later elections were held, and the officials who were elected under American supervision signed a treaty with the 


\section{PROBLEMS OF THE CARIBBEAN COUNTRIES 291}

United States which made that country supreme in the Haitian government except in the Department of Education-the one department where it would seem help could best have been given. While the reading of the treaty does not seem to indicate such a contemplation, a military government has since that time been maintained by the United States. But, unlike Santo Domingo, Haiti has a President, Cabinet and sometimes a Congress, with governors and local officials who function in certain matters when they are willing to cooperate with the American authorities.

There is a dual government in Haiti, one the native government and the other the American marines, headed by the general in command. If the native gendarmerie is counted, and it has large authority, there may be said to be three governments. Frankly, this three-cornered arrangement has created conditions that leave all parties confused and disgusted.

The man of most power is the Financial Advisor, an American who has practically absolute authority over the various items of expenditure by the national treasury. He recently withheld the salaries of the president and his cabinet for several months because they would not sign certain concessions desired by his government. The American in charge of education complains that it is most difficult to get the Financial Advisor to allow funds for education.

In matters like sanitation the usual practice is to detail an officer from the Navy or Marine Corps to serve under the Haitian Government. The gendarmerie, like the Guardia Nacional of Santo Domingo, is composed of native soldiers officered by American Marines, privates or non-commissioned officers who have been detailed by the Marine Corps for this work after they have stood examination in elementary French and in Haitian law. Marines are only stationed permanently in the larger towns, but the gendarmes are found scattered all over the country as well as in all the cities. Where both forces are found, their barracks are in different parts of the town. As the officers of the gendarmes are only enlisted men in the Marine Corps and the private gendarmes are Haitians, there is naturally little relation between the personnel of the two organizations. 
The marine who becomes an officer in the gendarmerie finds himself clothed with almost unlimited power in the district where he serves. $\mathrm{He}$ is the judge of practically all civil and criminal cases, settling everything from a family fight to a murder. $\mathrm{He}$ is the paymaster of all funds expended by the national government, he is ex-officio director of the schools, inasmuch as he pays the teaciers. He controls the mayor and the city council, since they can spend no funds without his $\mathrm{O} . \mathrm{K}$. As collector of taxes he exercises a strong influence on all individuals of the community. It is no wonder that an ordinary private in the Marine Corps, with a few months' residence in a foreign country, where people are at a very low stage of civilization and he himself has little or no preparation for such varied responsibilities as are thrust upon him, is often charged with many abuses and mistakes. When one sees the awful conditions under which these gendarmes officers are called to live he wonders if he himself would do any better under the same circumstances. But the fact remains that it is impossible to get forward in reforming a people who see nothing to admire in the reformer, who too seldom tempers justice with mercy, and at times even inflicts punishments more severe than the crimes merit.

It is with great hesitancy that one passes criticism upon our American marines. No man knows but that he might act the same way under similar conditions. It is the machine, not the man, that is to blame.

From the military standpoint it is natural to regard all life as cheap; especially if one is stationed in a country where people are little above the animal, where you are hated and your life is sought, if not by all, at least by organized bands who compel you to sleep with your hands on your weapons, and where if ever caught, you know you will be subject to unmentionable tortures before you meet a horrible death. Under such conditions it is easy to live up to the rule of "take no prisoners" and to show small respect for the rights and property of those who have no respect for you and little for themselves.

Military life, moreover, does not lend itself to civil reforms, for it is based on caste. Discipline is only maintained 


\section{PROBLEMS OF THE CARIBBEAN COUNTRIES 293}

by obeying your superior without question. The private is subject to the ire of the sergeant, the sergeant to the lieutenant, the lieutenant to the captain, and so on. And very likely the ire of all is visited on the civilian. As a young editor, who had to take his paper to the military authorities for their censorship before it could be published, said, "We want a civil government so we can approach them. You go to one of the military authorities. You know he is a very fine man. But he has a guard at the door who unceremoniously tells you, 'Get out, and do it quick!' " Is it any wonder that the bandit situation does not improve under such treatment or that the American soldier acts as he does under the conditions described, when he has never had any training for administrative or democratizing work?

The same thing applies to moral life. Who will throw the first stone at the man who is compelled to live away from all that is pure and ennobling, without religious or moral influences of any kind, of ten without books or recreation, without even a baseball or a Victrola, in the midst of the vilest native life, where men have little virtue and women small sense of shame? The whole thing is absolutely unnatural. If necessary for a few months under extraordinary conditions, it should certainly not be allowed to exist through the years-years during which men do not get into a pure atmosphere or see good women of their own race or hear a moral exhortation, as happens with some of our marines here. Such men have their whole moral make-up changed.

The best of the officers in Haiti realize that the situation is not satisfactory and are doing what they can to correct it. "So far we have done little for Haiti except stop the graft, and that has not made the people like us. It is time we were doing some constructive service for these people. I should like to see you begin the program of schools and hospitals you have outlined." Thus spoke the commander of the American marines in Haiti, Brigadier-General Catlin, who was wounded at Château-Thierry. Of course he did not mean to be taken literally, because already much has been accomplished in the building of roads, sanitation of cities, improvement of the postal service and other public 
activities. The national debt, which threatened the independent life of the nation, is being gradually liquidated, and revolution, which stifled all economic development, has been suppressed.

If our Government is to go forward satisfactorily with the tremendous job it has begun, there must be in every case the most careful selection of the men who are sent to deal with these people. When we began our work in the Philippines we sent a man like Chief Justice Taft to begin the development of the people into a democracy. He found much the same conditions as now exist in Haiti. When he began to talk about "our little brown brother" it took strong measures to repress the sarcasm of the soldiers, who sang, "He may be a brother of William H. T., But he ain't no kin to me." But the new spirit prevailed and to-day the development of the Filipino toward democracy is the pride of every American. The job in Haiti is a harder one, but it can be accomplished by a combination of the highest type of administrative and moral leadership.

The following extracts from the letter of a naval officer emphasize the duty of the United States to render an unselfish service to the backward people of this island:

"In I9I4, when I was on duty in Haiti and Santo Domingo, the thought occurred to me how the natives of this island had been neglected by the various philanthropic and religious societies of the United States.

"After five years in Europe I have once more returned to Santo Domingo. Meanwhile we have actually taken over the government of this island and our moral responsibility for the improvement and progress of the natives has been greatly increased, while I note the same indifference on the part of the various philanthropic and welfare organizations of the United States toward this work.

"The citizens of the United States, out of private funds, have spent millions of dollars in helping and assisting the peoples of war-stricken Europe. The peoples of warstricken Haiti, our own particular wards, the responsibility for whose betterment we cannot escape, in view of the occupation, have received practically nothing. 
"Europe has suffered from the devastation of wars for five years; Haiti and Santo Domingo for over a hundred. At least fifty per cent. of the population are practically reduced to savagery; a certain proportion are in the same condition as their ancestors were when they were brought in slavery from the African jungles.

"Now that the United States has occupied the island, the American people should no longer remain in ignorance of the true conditions. As soon as they realize and can visualize the state of affairs, knowing that now we are legally and morally responsible and have got to see the thing through, I'm sure they will respond as they have always done to stricken and unfortunate branches of the human race."

The whole annual budget for education in Haiti in 1918 was $\$ 340,000$. Cuba, with the same number of people, spent $\$ 7,000,000$. Porto Rico, with half the population, spent $\$ 4,000,000$; and even Santo Domingo, its next door neighbor with a third of the population of Haiti, will spend this year, under the American colonel of marines who directs her education, $\$ 1,500,900$. This story would not be nearly so bad if this $\$ 340,000$ were spent in the right way. A large part of it heretofore has been wasted on the political army. Many of the teachers who have been appointed in the smaller towns never go to the schoolhouse and indeed there often is none. A captain of the gendarmerie told me of a woman coming in to draw her pay as a school teacher. When he gave her the receipt, she signed by a cross. He asked her to write her name. She said she did not know how to write, and when reproached for this she said that she was the teacher of reading, not of writing!

The limited traffic in ideas may be judged from the fact that the number of letters mailed in Haiti in a year is about equal to the number dropped into the mail boxes of New York City on any business day between five and seven o'clock in the evening. There is no question that the biggest job of the United States in its development of Haiti is the increase in traffic of the right ideas-education in its broadest sense.

As I review the whole situation in Santo Domingo and 
Haiti, the condition at present seems to me very unsatisfactory. In the American military rule there has been incompetency, cruelty, immorality and a tendency to lower conduct and administration of justice to the level of the natives rather than to lift it to the standard of American democracy. On the other hand there has been much real effort to serve in the spirit of true American altruism. The system, not the personnel, is the thing that is not American.

The people of the United States ought to understand that while they are minded to pay no attention to our relations with the small countries, naively supposing that because we are who we are our actions will always be altruistic and the world will recognize that fact-the people of the United States ought to know that the world is continually talking about these things. It has taken a presidential campaign to get a few columns into the newspapers about Santo Domingo and Haiti. But a book could easily be filled with quotations from the Latin American press during the past year on this subject. Of course it is idle for any political party to try to make capital out of our relations with Santo Domingo and Haiti, because they are only a part of the whole drift, evident in Cuba, Porto Rico, Panama and Nicaragua, toward making the Caribbean Sea an American lake.

The American people may believe that this is the right thing to do. But they have never said so. They have never expressed themselves for or against, through a general public discussion, the platform of a political party or even a vote of Congress. They should no longer avoid the obligation to do this. England has in her government a department for the handling of her colonial problems, and the English people keep close watch over it. Means are provided for representatives of the colonies to be heard and officials of the Crown are especially trained for this work. Certainly if after due consideration we decide to govern (and we are governing) these small countries, either politically or entirely, we ought to say to them and to the world what we intend to do and straightway prepare to do it in the way that accords with the highest American traditions. Such a step would of course lead to the alteration of a good many of our diplomatic declarations about the rights of 


\section{PROBLEMS OF THE CARIBBEAN COUNTRIES 297}

small nations, concerning Pan Americanism, and the twentyone American republics, "each free and equal."

\section{CENTRAL AMERICA}

Central America is similarly under the influence of the United States as are the countries already mertioned. In order to understand the relations between these two larger entities, one must know something of the relations of these smaller entities among themselves. Remembering that Panama has never been a part of Central America, we find that in Colonial days, the five divisions now called republics were under the one Viceroyalty of Guatemala. Their independence was secured without great effort in 1821 , and in 1823 they formed the Federation of Central America. Unfortunately local jealousies did not permit the continuance of the Federation, which was dissolved by an act of its own Congress on May 30, 1838 .

Ever since that date the most discussed subject in all the five republics is that of the reunion of these countries. In 1842 , I $848,1852,1862$ and 1872 schemes for union were worked out but not adopted. General Justo Rufino Barrios, president of Guatemala, endeavored to force union by war, and was killed on the field of battle, April 2, 1883. The efforts since the time of Barrios have been too numerous to mention. Whenever a revolutionary leader is looking for a rallying cry or a president wishes to recuperate his waning power he lays hold of the cry for unity.

The first Central American Juridical Congress, held in June, I897, at Guatemala City, laid the basis for unifying various important activities. The treaties that were then signed dealt with mercantile law, penal law, extradition, literary, artistic and industrial property, civil law and legal procedure; and four years later with political and international law. A second Juridical Congress was held at San Salvador in February, I90 I, when additional treaties providing for ratification of the preceding arrangements were signed.

The Peace Pact signed at Corinto in 1902 began the important movement which culminated in the joining together 
of the United States and Mexico to help bring permanent peace to the disturbed lands. A Peace Conference fostered by the lwo nations was held aboard the U. S. Cruiser, Marblehead, in 1905, with satisfactory results. When fresh troubles broke out, the two friendly nations decided to invite the contending parties to Washington to have them go into the whole Central American question and find, if possible, a solution for their difficulties once for all. This notáble conference met on November I3, 1907, and was in session for five weeks. The North American and Mexican representatives were considered not only as members of it but as legal advisors of the Central American delegates. Secretary of State Elihu Root and Ignacio Mariscal, Minister for Foreign Affairs of Mexico, were elected as honorary presidents. Secretary Root occupied the chair during most of the inaugural session and spoke as follows:

"The all-important thing' for you to accomplish is that while you enter into agreements which will, I am sure, be framed in consonance with the most peaceful aspirations and the most rigid sense of justice, you shall devise also some practical methods under which it will be possible to secure the performance of those agreements. $* * *$ To find practical definite methods by which you shall make it somebody's duty to see that the great principles you declare are not violated, by which if an attempt be made to violate them the responsibility may be fixed upon the guilty individual -those, in my judgment, are the problems to which you should specifically and most earnestly address yourselves."

In his inaugural address as permanent president, Luís Anderson, Minister for Foreign Affairs of Costa Rica, said:

"The solemn inauguration of this Central American Peace Conference marks in the history of our people the epoch that separates the past from the future, the time when war and revolution will sink, never to rise, to give way to peace, progress and tranquillity. It is the beginning of an era to which the spirit of the century urgently calls us.

"Civilization cannot allow that in the family of nations 


\section{PROBLEMS OF THE CARIBBEAN COUNTRIES 299}

there be one which does not work for or contribute to the common benefit the full extent of its energies and of the wealth with which nature has endowed it, because all nations are united in human progress.

"Admirably situated between two continents, with extensive coast lines on both oceans, with an exceedingly rich soil, suitable for all kinds of products, with mountains full of gold and silver-in fine, with such wealth that it would seem nature took pride in scattering over these lands all its riches with a prodigal hand-Central America is in duty bound to render to civilization, through universal interchange, all the benefits that its privileged situation demands."

The seven documents prepared by the conference have since become the virtual constitution of a new Central America. A general treaty of amity was negotiated to run ten years. It declares that every difference or difficulty that may arise among them, of whatsoever nature it may be, shall be decided by a court, and that any attempt to alter by violence the constitutional organization of any state is to be deemed a menace to the peace of all. The territory of Honduras-which lies between Guatemala to the north, Nicaragua to the south and Honduras to the west and which frequently was Central America's battle-ground,-was neutralized. Each state obligated itself to accredit permanent diplomatic legations to the others, and all Central Americans were again mutually recognized as citizens. They promised to prevent political refugees from living near their borders, to refuse to recognize any government resulting from a coup d'état or to intervene in any republic on account of internal disorder. They agreed that each country should try for a constitutional reform by which the re-election of a president should be prohibited.

The second convention created the Central American Court of Justice, the most remarkable judicial organ in the world, to be situated at Cartago, Costa Rica. The five sovereign states gave this court authority to determine all questions arising between them which diplomacy should fail to settle; to determine cases involving alleged violation of treaties where denial of justice should be charged by a citi- 
zen of one country against the government of another, and to determine any question submitted by two governments, or by a government and a citizen of any of the five states. Further, the court determines its own competency respecting cases brought before it and decides all questions of fact according to its own judgment. Its decision is final, but must be rendered by a majority. An optional article makes it possible for the court to take jurisdiction "over the conflicts which may arise between the legislative, executive and judicial power, and when as a matter of fact the judicial decisions and resolutions of the national congress are not respected" in any state, a provision which was not fully ratified.

The third convention provided for mutual extradition of criminals and defined extraditable crimes.

The fourth convention aimed "to develop the interests common to Central America." To this end an international Central American bureau was established "to combine every effort toward the peaceful reorganization of their mother country, Central America." The bureau, with duties specified in some detail, was placed at Guatemala and its membership consists of one person from each of the five states.

The fifth convention created a Central American pedagogical institute, establishing a normal school and aiming to bring about a common system of education in the five states.

The sixth convention provided for annual conferences for five years.

The seventh convention contemplated measures looking toward the proper connection of the several republics by railroad.

\section{INAUGURATION OF THE CENTRAL AMERICAN COURT}

The Central American Court of Justice was recognized from the beginning as the most important creation of the I907 conference. It had an auspicious beginning. Its installation was set for May 25, I908, and Costa Rica, the host, invited delegations from the United States and Mexico, the godparents of the whole scheme. William I. Buchanan of the United States and Enrique C. Creel Mexican Ambassador to Washington, were chosen to represent their 
governments, and Mr. Buchanan at once started for Mexico. On May I4 Mr. Buchanan, Mr. Creel and parties went on board the United States cruiser Albany.

Señor Luís Anderson said in the opening address:

"Arbitration has been contemplated as a sure means of arriving at pacific solutions, and those peoples who have been favored thus have accumulated strong proofs of its efficiency in their national life and have escaped in their history pages of sorrow.

"In the history of the countries of Spanish America the noble idea has a glorious origin. It was born with their independence as though inseparable from liberty, and as a necessary element in their existence, since liberty surges from truthful force, which resides in justice. It was thus comprehended by the genius of Bolivar at the very beginning of American emancipation, and, notwithstanding frequent and lamentable vicissitudes, is to-day, germinated by the deep desire of Central American patriotism developing itself, and will soon begin to give abundant and beneficent fruit. $* * *$

"Civilization does not halt in its march while there is a step in advance to be taken, but day by day transforms ideas into doctrines and doctrines into institutions. All realized progress is crystallized into practical and fundamental form after the natural period of evolution of idealistic theory. For this reason great thinkers believe that the idea of international arbitration, a simple humanitarian doctrine contemplated by philanthropists as the base of a superior aspiration, must be carried farther and be converted into an institution which shall form an integral part of the organism of nations. ***

"The glory of making the first attempt at such an institution, worthily represented by this Court of Justice for Central America, belongs to us."

Minister Buchanan, to whose patience, wisdom and sacrificial labors was due so much of the success of this movement, closed the proceedings with an announcement of great interest, as follows: 
"I have received a telegram from His Excellency, the Secretary of State of the United States, Hon. Elihu Rost, instructing me to advise your Excellencies that he has been authorized by Mr. Andrew Carnegie to offer the sum of $\$ 100,000$ for the construction in the city of Cartago of a temple of peace to be destined for the exclusive use of the Court of Justice for Central America, as a mark of his good wishes for the peace and progress of Central America and of his confidence in the success of the great work of humanity and justice which is to spring from this court, which is to constitute a new and splendid example of civilization, of peace, of justice, and of confraternity in the relations of the countries represented here."

The Central American Court of Justice had the broadest jurisdiction ever instituted in a permanent system between nations. In some respects it was even broader than any temporal international tribunal has ever had, and compares favorably with that of national courts. Therefore it marked an advance in a world where enlightened opinion was rapidly crystallizing around the idea that an international legal system, definite in character and operating with certainty, was absolutely necessary.

That this most remarkable experiment in international good will ever known to history was terminated ten years later largely because the United States, the sponsor of the whole idea, refused to abide by one of its decisions, thus robbing it of its prestige, is one of the strangest tricks of fate.

\section{NICARAGUA}

In order to understand the failure of the Court of Justice we must go to Nicaragua which, with Panama, has been kept in turmoil for many years because of its possessing that rare and much prized economic asset, an interoceanic canal route. Uneasy lies the head that wears such an adornment! Both Great Britain and the United States began early to flirt with Nicaragua to gain this prize. The United States concluded its first treaty with Nicaragua for the canal route in 1840 . Around this theme was played the bloody drama 
of the filibuster Walker, who for many years flaunted the worst in North American life before the helpless Central Americans in an endeavor to capture this rich prize.

Passing over many intensely interesting events in the flirtation and oppressions between Nicaragua and the outside world, we come to the rule of President Zelaya, who was Dictator of Nicaragua from I 894 to I9IO. He was one of the most arrogant meddlers in international politics ever known. One of his hopes was to become the strong man of Central America and show the Yankees where they belonged. His arbitrary conduct and financial difficulties with foreigners brought bombardments from British battleships on two different occasions. One of his tricks was to intimate to Japan that a bid for the canal route from her would be well received. The United States did not propose to stand longer for such a disturber. So, when in a revolution against Zelaya in 1909, two North American soldiers of fortune, caught in the act of blowing up a government steamer, were executed, the United States landed marines and forced Zelaya to flee from the country. Secretary of State Knox, in handing the Nicaraguan Minister his passport on December I, I909, said: "Since the Washington Convention of 1907 it is notorious that President Zelaya has almost continuously kept Central America in tension or turmoil; that he has repeatedly and flagrantly violated the provisions of the conventions, and, by a baleful influence upon Honduras, whose neutrality the conventions were to assure, has sought to discredit those sacred international obligations, to the great detriment of Costa Rica, Salvador and Guatemala, whose governments meanwhile appear to have been able patiently to strive for the loyal support of the engagements so solemnly undertaken at Washington under the auspices of the United States and of Mexico. It is equally a matter of common knowledge that under the régime of President Zelaya republican institutions have ceased in Nicaragua to exist except in name, that public cpinion and the press have been throttled, and that prison has been the reward of any tendency to real patriotism."

Zelaya turned over the presidency to Dr. José Madriz, tut he was also forced out by the United States and the 
Conservatives were established in power. In I9I2 General Luis Mena led a revolution, which threatened the overthrow of the government backed by the United States. Some 2,000 marines were sent to Nicaragua in order "to protect American life and property." The liberal movement was put down at a great loss of life, and fresh elections were called under the protection of United States marines. Our Government would only agree to a Conservative candidate, so the Liberals refused to vote. And from that time till the present, marines have maintained a Conservative president in the chair, as all evidence seems to indicate, against the wishes of the great majority of Nicaraguans.

As the note sent by the Taft Administration to Minister Weitzel at Managua, September I8, I9I2, on the occasion of the second landing of marines, since when a permanent company have been maintained there, outlines a general policy, it is here given:

"The policy of the Government of the United States in the present Nicaraguan disturbances is to take the necessary measures for an adequate legation guard at Managua, to keep open communication, and to protect American life and property.

"In discountenancing Zelaya, whose régime of barbarity and corruption was ended by the Nicaraguan nation after a bloody war, the Government of the United States opposed not only the individual, but the system, and this Government could not countenance any movement to restore the same destructive régime.

"The Government of the United States will, therefore, discountenance any revival of Zelayaism, and will lend its strong moral support to the cause of legally constituted good government for the benefit of the people of Nicaragua, whom it has long sought to aid in their just aspiration toward peace and prosperity under constitutional and orderly government.

"Under the Washington conventions the United States has a moral mandate to exert its influence for the preservation of the general peace of Central America, which is seriously menaced by the present uprising, and to this end, 
in the strict enforcement of the Washington conventions and the loyal support of their aims and purposes, all the Central American republics will find means of valuable cooperation.

"When the American Minister called upon the Government of Nicaragua to protect American life and property, the Minister for Foreign Affairs replied that the Government troops must be used to put down the rebellion, adding: 'In consequence, my government desires that the Government of the United States guarantee with its forces security for the property of American citizens in Nicaragua, and that they extend this protection to all the inhabitants of the republic.'

"In this situation the policy of the Government of the United States will be to protect the life and property of its citizens in the manner indicated, and meanwhile to contribute its influence in all appropriate ways to the restoration of lawful and orderly government in order that Nicaragua may resume its program of reforms unhampered by the vicious elements who would restore the methods of Zelaya."

The communication closed with a denunciation of General Mena, leader of the present insurrection, whose revolt is declared to have been in flagrant violation of promises, without even the pretence of contending for a principle, and "in origin one of the most inexcusable in the annals of Central America."

Criticism of and opposition to this line of policy was not lacking in Central America or elsewhere. Never before was it made quite so plain that no government can survive in the five republics between Mexico and Panama without the approval and the moral support of the administration in Washington.

The culmination of this policy of "moral mandate" was reached when, in 1916 , the Bryan-Chamorro treaty was signed. Nicaraguans claim that this was the complete selling out of their country by a president whom they had not put in office and who had no right to represent them. This statement is backed by many reports of Americans in Nicz.ragua, like that of Lieutenant Colonel Charles G. Long, 
who wrote on November I2, I9I2, that "The Liberals constitute three-fourths of the country. The present government is not in power by the will of the country."

The Bryan-Chamorro treaty contained the following im. portant stipulations:

(I) Supervision of Nicaraguan affairs by the United States.

(2) United States to be granted rights to construct a canal through any part of Nicaragua that it should determine. For this the sum of 3 million dollars should be paid Nicaragua, to be spent under the direction of the United States.

(3) Lease to United States certain islands and the Fonseca Bay for fortification and a naval base.

On account of opposition in the United States Senate, the first provision for a kind of a "Platt Amendment" was deleted.

Indignant protests began to be heard all over Central America as soon as the treaty was published. Mass meetings were held throughout the countries, and protests were sent to the United States from prominent men and organizations of Central America. The following extracts from the press show the spirit of resentment:

La Informacion, Costa Rica, said on July I, I914:

"*** Everybody is aware that $* * *$ our sovereignty is threatened, at least in part, through the unbelievable acts of the men governing Nicaragua. Not satisfied with offering their own country to the United States, they included a part of Costa Rican territory."

El Cronista, of Honduras, on August 7, 1914, declared:

"*** American interference in the land of the lakes (Nicaragua) will not stop, and the new feature of the protectorate still threatens the other small republics.

"* * * Young Honduras heatedly protests against the threat of Bryan of a protectorate, and must feel that the danger is not passed. $* * *$ " 


\section{El Cronista declared further on August 21, I9I4:}

“*** The tutelage of the United States over Central America is well known; and it is evident that it will become stronger as a result of the European War.

"*** There is nothing new in that the United States has not given up her intention of creating protectorates from Guatemala to Costa Rica, ruinous not only to CentralAmerican sovereignty, but to human justice as well. *** We shall fall victims to political hunger. ***"

"We must realize that we are to-day threatened by the corrupt 'dollar diplomacy,' applied with unheard-of impuclence by the Executive of the great American nation whose history speaks with legitimate pride of glorious Washington and Lincoln, respected throughout their country for their strict observance of right, justice, and liberty, to which the weaker nations now appeal against the threat of the modern conqueror.

"But if, unfortunately, the eagle of the North finally succeeds in burying his claws in the entrails of our country and wipes out our national existence, let us be content with at least saving the dignity and pride of the race by throwing our energetic protests with sacred fury at the Northern invader, and perishing arms in hand and head uplifted!"

Costa Rica and El Salvador immediately brought suit in the Central American Court of Justice for the annulment of the treaty on the ground that Nicaragua had no right to sign away her sovereignty without consulting the other Central American countries, and particularly could not give any rights in Fonseca Bay, which had always been considered the undivided property of Honduras, Salvador, and Nicaragua. They also showed that the establishment of an effective naval base by the United States would mean placing of guns on points that would command territory of Honduras and Salvador.

The judges upheld the claimants against Nicaragua by a vote of four to one, the Nicaraguan judge of course voting against the decision. Nicaragua and the United States leclined to accept the decision. Thus the United States, 
which was responsible for the establishment of this, the only court of arbitration in the world, allowed the court to close its doors in ignominious defeat on March I5, 1918.

In Nicaragua the outstanding influence is the one hundred United States marines who live up on the hill dominating the city. A hundred marines are not many, but as one gentleman expressed it, "When we see that hundred up there, we see a hundred thousand behind them and then behind them a hundred million. So we know we must not displease Tío Samuel."

The American bank that owns the railroad and dictates the financial policies of the country and the American customs collectors are the predominant forces that persuade the Nicaraguans to court the favor of the United States or curse their luck, as the case may be.

On a visit to Nicaragua in 1920 I had a perfect avalanche of callers and requests for engagements, for they were fancying that maybe this American could have some influence in getting his government to better their conditions. Soon my days were divided up, one with the editors, one with the educators, one with the literati, one with the cabinet, one with the supreme court, and so on.

The presidential elections were very close and the main question with the Conservative party was, "Will our big Uncle stand by us as before and keep the opposition from armed rebellion, so that we may continue in power?" The Liberals no less insistently asked, "Will the United States force the Conservatives to let us vote at these elections so that we may put in a man who represents the majority of the people?"

The Liberals now claim that, since the United States interfered once with their internal affairs the only just thing for it to do is to compel fair elections-that if it keeps its hands off, that will mean the continuance of the Conservatives in power, since they will count themselves in, however, the voting may go.

The following letter from Senator Root, written to a friend, is a splendid statement of the question:

"I understand you are going to see the President regard- 


\section{PROBLEMS OF THE CARIBBEAN COUNTRIES 309}

ing Central American affairs and that before you see him you wish to know what I think about the effect of the pending Nicaragua treaty. I confess I am a good deal troubled about it. I felt that it was desirable to do what the treaty provides for, that is to say, to protect our Panama Canal by securing an exclusive right to the Nicaragua route so far as the Republic of Nicaragua can grant it, and to have the right to a naval station in Fonseca Bay. I was not in favor of the more extensive provisions originally proposed, similar to those in the Platt Amendment, which unduly interfered with the independence of Nicaragua. I was unwilling to have our government accept from any Nicaragua government a grant of power which I felt certain the people of Nicaragua would not and ought not to approve. With those provisions out, however, and nothing left but the grant which I have described, I voted for a favorable report on the treaty. I am, however, troubled about the question whether the Nicaragua government, which has made the treaty, is really representative of the people of Nicaragua, and whether it will be regarded in Nicaragua and in Central America as having been a free agent in making the treaty. I have been looking over the report of the commanding officer of our marines in Nicaragua and I find there the following: "The present government is not in power by the will of the people; the elections of the House of Congress were most fraudulent.'

"And a further statement that the Liberals, that is to say, the opposition, "constitute three-fourths of the country." It is apparent from this report and from other information which has in a casual way come to me from various sources that the present government with which we are making this treaty is really maintained in office by the presence of United States marines in Nicaragua. I am told that if the marines were withdrawn the present President would be obliged to leave the country immediately or he would be expelled by a :evolution. This situation raises a very serious question, not about the desirableness of the treaty, but about the way in which the treaty should be made. Can we afford to make a treaty so serious for Nicaragua, granting us perpetual rights in that country, with a President who we have reason 
to believe does not represent more than a quarter of the people of the country, and who is maintained in office by our military force, and to whom we would, as a result of the treaty, pay a large sum of money to be disposed of by him as President? I should be sorry to see the United States get into that position. We don't want to maintain a government in Nicaragua by military force perpetually, and it is highly probable that if we were to withdraw our force after making such a treaty there would be a revolution and the treaty would be repudiated, leaving us in a position where our legitimate moral influence would be destroyed and nothing but brute force left. There is a good deal of evidence that the other people of Central America look at the subject in this way. I should be very sorry to see the Central Americans convinced that we wish to rule them by force, for it would be the end of all our attempts to benefit them and help them along as we have been trying to do. I think that we ought to keep before us always as an objective the building up of a stable and orderly Central American Union, and a good deal of progress in that direction has already been made. The treaties which were agreed upon at the Central American Conference in Washington in 1907 contribute in a practical way to promote an approach toward ultimate union. It seems to me that there is a great opportunity now to try to bring the Central American states together because of their active interest in this proposed treaty with Nicaragua. At all events, I feel that for our own protection and for the good of Central America we ought to make some provision by which there shall be either a submission of this treaty to the people of Nicaragua under a fairly supervised election, or the election of a new government under such supervision as to prevent fraud in election, and then let the new government, representing the majority of the people of Nicaragua, pass upon the ratification of the treaty."

\section{EL SALVADOR}

Students of Central American politics need to give close attention to little Salvador. If the Chileans are the Yankees of South America, the Salvadoreans are the Chileans 
of Central America. A hard-working population (comparatively), a lack of revolutions, numerous small industries, a well-organized army, emphasis on secondary education (always comparatively, remember), a strongly developed nationalism with a converse questioning concerning North American imperialism, and a pride of leadership among sister states-these and other characteristics remind one familiar with South American states of vigorous little Chile.

One of the most democratic presidents I have met in all Latin America is Don Jorge Melendez, who talked with me nearly an hour recently in the most informal way about the people of Salvador, the difficulties of avoiding revolutions in Central America, financial and political relations with the United States, and other questions.

Because Salvador was the only Central American Republic that did not join the Allies in the war against Germany and because she has recently asked the United States for a definition of the Monroe Doctrine, it was particularly interest. ing to hear the President declare his desire for close relations with the United States. Because his ideas seem to be so well represented by the words of his brother, whom he has just succeeded in the presidency, I give them here:

"If American diplomacy, in its relations with the Central American peoples, maintains unimpaired the principles of equity and justice laid down by President Wilson, principles of cordiality, confraternity and respect for the sovereignty of these peoples, such a policy of mutual consideration and good understanding will be the foundation for closer commercial relations between the United States and Salvador, as well as among the other republics of the American continent.

"The best means of rapprochement for two peoples is an intimate reciprocal knowledge of their peculiar moods, their psychology, their ideals and initiative in the path of civilization. North Americans have made very little systematic and methodical effort to comprehend the characteristics of the political and social evolution of our small nationalities. As a general rule, with but very few exceptions, North Americans know very little about our peoples because of 
false representations prompted by impulsive meddling with these young states.

"The interchange of university professors and students would be an effective means of promoting mutual acquaintance.

"The sending of lecturers to our universities, the establishment of good daily papers and magazines in the Spanish language, having a wide circulation in these countries, will contribute to the spread of information about the resources and characteristics of the North Americans in our midst.

"It behooves the statesmen, bankers and manufacturers of the United States to make effective the most important part in the relations between the United States and Salvador."

Behind those words of Don Carlos Melendez is the fact that during the war, when he was President, Salvador had much pro-German sentiment, which kept the country from entering the war on the side of the Allies, although it declared a benevolent neutrality toward them. For many years there has been a more marked tendency in Salvador than in other Central American countries to question the intentions of the United States with reference to Latin America.

Her protest against the Bryan-Chamorro treaty was most vigorous. She claimed that the Fonseca Bay is the common property of the three countries which it touches, and that the establishment of a naval base there and the fortification of some of the islands would give the United States, with long range guns, absolute command of Salvadorean territory and in case of war make her neutrality impossible.

It may be said in parenthesis that when one sees the Bay it is easy to understand the truth of this statement. The fact that this protest, although sustained by a majority of the Central American Court of Justice, was unattended by the United States and did not serve to lessen suspicion of America's imperialistic motives.

During the Second Pan American Scientific Congress in Washington in 1916 the Salvadorean delegate, Dr. Alonso 
Reyes Guerra, bearded the eagle in its nest and said plainly that before there could be any real Pan Americanism four things were necessary: first, a declaration that the prohibition against the conquest of American territory contained in the Monroe doctrine applies to the United States as well as to European countries; second, the adoption of the Drago Doctrine, which makes the collection of debts exclusively an internal question to be handled within each nation itself; third, elimination of all exceptions to the doctrine of nonintervention; fourth, the institution of obligatory arbitra. tion of all international disputes.

\section{GUATEMALA}

Guatemala has been one of the countries that has most easily "followed the mind" of the United States.

The outstanding event in Guatemala recently was the fall of Cabrera, one of the last of the old order of Dictators in Latin America. It is claimed that he was sustained in his career of more than twenty years by the backing received from the United States.

I was in Guatemala both immediately before and immediately after the revolution. Having talked with Cabrera about his policies during my first visit, I desired to compare him with the new President on my second visit, which resulted in an experience illustrative of the difficulty of keeping straight on Central American politics.

Asking a friend whether he thought I could see the President to find out about his proposed program, he replied that he thought I could and told me where to find him. Following the directions I came to a private house which had a few soldiers in front of the door and, on explaining that I wished to see the President, my card was taken in where I saw a patio full of ragged soldiers. Pretty soon a gentleman in military uniform came out and asked me what I wanted. I told him that I was anxious to see the President and talk with him about his new program. The gentleman seemed to be a little confused and I again explained that I nvas now going back to the United States and wished to carry a message from the new President to the American 
people. But still he did not seem to understand and I began to wonder if my Spanish was at fault. After I had made the third attempt to explain to him how important it was for me to see the Chief Magistrate and find out his attitude toward things American, he looked at me in a queer way and said, "You must want to see the new President. It is the old one that we have here in jail." As I had seen the old President a few weeks before, I had no desire to see him again and hurried on up to the house of President Herrera, to which I was directed, where I had a long interview with him.

"Tell the people of the United States that you met in Guatemala a friend of the Americans," said Don Carlos Herrera, the new President, when I finally found him. "As to my program," he continued, "in two words it is to follow as closely as possible the development of democracy as it has taken place in the United States. In Guatemala we have everything to do and I know of no better way of doing it than studying carefully what has been done in the United States. I have for a long time been a great admirer of that country. My two boys were educated there. I have visited the country myself; have for a long time had business connections with many of its large commercial organizations, and believe thoroughly that the best thing for our country's development is to maintain cordial relations with the United States."

President Herrera is a new type of ruler for Guatemala. $\mathrm{He}$ is not a military man or even a politician. His administration will no doubt be mainly a business administration, devoted to the development of Guatemala's wonderful economic resources.

President Herrera was anxious for me to see his Minister of Foreign Affairs, Señor Aguirre, in order to talk with him more in detail concerning the lines along which the administration would like the help of the United States. The Minister is a cultured gentleman who has traveled widely, speaks several languages and is in every way a cosmopolite.

"We must have the help of the United States," said Señor Aguirre, "along three lines particularly. First, we need 
your moral help. In the past Guatemaltecos have had to hang their heads because of the utter backwardness of their country and the lack of liberty we have enjoyed. All of this must be changed. We must come out into modern life. We realize that fundamentally our problem is a moral one and we are not strong enough to cope with this problem alone. We earnestly hope for the help of the United States in the development of our moral life. Second, we need financial help. Guatemala is one of the richest countries in the world. There is practically nothing that we cannot produce. We have not only the finest coffee in the world but wonderful sugar and all kinds of tropical fruits. There is an opportunity to further develop our agriculture and also for building factories. With all of our fruit, canning factories would give splendid results. Our water power furnishes great opportunities for the development of electricity. We ought to have several North American banks immediately.

"There is also an opening for wholesale and retail stores handling exclusively American goods.

"In the third place we need your help in education. Here almost everything is to be done. While the previous administration pretended to be a friend of education and erected a certain number of showy buildings, they have been little more than shells. The education of the more than a million Indians in our population is in itself a tremendous problem. We must make our education modern and to whom can we look for help so much as to the United States, which has advanced so rapidly along educational lines?

"My idea also is to make Guatemala a modern Mecca for American tourists. We have one of the finest climates in the world, some of the most beautiful scenery, with mountains and lakes more wonderful than those of Switzerland and we are within three days of New Orleans. Our policy is to throw open the gates to all friends of progress. We want the world to come and see us."

The greatest criticism that the Guatemalan people had of the United States Government during the exciting days of the revolution was the publication in the Gautemalan 
press of a note from the State Department which indicated that our government was very much opposed to the revolution. The revolutionary forces had conducted themselves in a most commendable way. The reform or "Unionist" movement represented at least ninety per cent. of the nation and only resorted to arms when Cabrera had cannonaded the city. It did not therefore seem consistent with the history of the United States or with the ideals of liberty for which we stand that our government should publish a statement which seemed to command the Guatemalans not to revolt against one of the worst tyrannies to which a people were ever subjected.

The following is the American note which caused such unfavorable comment:

"Mr. Benton McMillin, Envoy Extraordinary and Minister Plenipotentiary of the United States of America to Guatemala, after the issuance of the President's proclamation, issued, with the authority of his government, the following for publication:

" "The steady policy of the Government of the United States is to encourage constitutional government and free elections in Central America. Having the greatest interest therefore in the constitutional progress of Guatemala, the Government of the United States has learned with great pleasure of the proclamation of President Estrada Cabrera regarding constitutional guarantees and has confidence in view of the statements just made to this Government by President Estrada Cabrera, that he will faithfully carry out the reforms proclaimed.

" "The Government of the United States is opposed to revolutionary measures and firmly believes in view of President Cabrera's proclamation there is no excuse for starting a revolutionary movement in Guatemala and that therefore in the eyes of the civilized world the gravest responsibility would rest with any man or group of men who should start such a movement. The Government of the United States particularly desires to see peaceful constitutional progress in Guatemala and would regard with horror any actions which should cause a needless and inexcusable revolution to 
PROBLEMS OF THE CARIBBEAN COUNTRIES 317

be commenced in that country." (From Diario de CentroAmérica, Guatemala, April 5, 1920.)

It ought to be said that this note was published by Minister McMillin not because of his approval of its contents but by order of superior authority.

Things in Guatemala are becoming reorganized and there are evidences of a new day. The ordinary revolution in Central America is an opera-bouffé affair, but this upheaval in Guatemala has been justified if any revolution in the world was ever justified. Many of the men who are now in power have suffered terrible tortures for long years for the sake of liberty. They have learned by these sufferings the cost of liberty and it is hoped that they will work for a really democratic government in one of the richest countries of all the Americas.

\section{CONCLUSIONS}

On September 15, I92 I, Central America concluded a century of independence from Spain. This event was celebrated by another effort at Unity which has resulted in Guatemala, El Salvador and Honduras definitely setting up a united government with Tegucigalpa as the capital. With the encouragement of the United States no doubt the other two republics would enter the Union and assure its success. Past failures should not discourage, for Central America is fast becoming a new land. The political advance since the Washington Convention of 1907 has been remarkable. Revolutions, fostered in adjoining countries, are becoming more scarce. The Zelayas and Cabreras are gone, never to return. Best of all, the people themselves are changing. No longer are the young men shut up to a career of politics. They are now turning their attention to commerce, agriculture, banking, mining and other industries. Let us hope that the old bone of contention, the canal route, will cease to be the disturbing element as in the past. States without the route wanted to federate, so as to get a piece of the pie, and the state with the route wanted the whole benefit of it. Ambitious dictators wanted to federate for 
their own fortunes. But the canal has been built in Panama, and the concession for another has been given to the United States. The disputes concerning this concession are easily arbitrated, so that the question of canal routes should no longer disturb the Union. In personal conversation with the leaders of the various countries I found practically a unanimous feeling that the United States should use its good offices to bring about and support this Union. This she could easily do without appearing officious. In fact, we should be far more justified in showing an interest in such a worthy object than we have been in imposing our will in connection with canal routes, banks, railroads and petroleum. One of the strange things about the dealings of the Lepartment of State, with the Caribbean countries, is its great sensitiveness in interfering with the affairs of a sister nation by way of encouraging some needed educational, moral or political reform and, on the other hand, its readiness to land marines, make and break presidents, and all the rest of it for "the protection of life and property"- - generally with a strong emphasis on property, possessed or desired.

In Central America I found a different attitude toward the United States from that in any other part of the Southland. There seems to be a rather general feeling that there is no use of longer kicking against the pricks. The North American influence must remain predominant and the best thing to do now is to work toward making it a just influence. While there is plenty of the kind of prejudice that Ugarte and his school stand for in other parts of Latin America, and there is much resentment at direct interference with the internal affairs of the various countries, especially in regard to the presence of the marines in Nicaragua and the Bryan-Chamorro treaty with that country, the reasoning of the average man seems to run something like this: "Our economic life must necessarily depend very closely on the United States. We need the help of the United States in stabilizing our political life. We do not object to receiving such helpful influence. But what does keep us continually resentful is the use of the marines to protect foreign investors and keep in power an administration that is despotic, while doing nothing toward helping the people in gen- 
eral to better their condition. Let your influence be toward a positive program of improving our political, economic, educational and social life, not in suppressing self-expression and just nationalism. If you assume the authority to say we cannot have revolutions, then you must also assume the authority to compel our rulers, whom you protect, to give us political and economic justice. We are independent nations and we would like to run our own affairs. But we admit that economically we are bound inseparably to you; politically we need your steadying influence to bring all Central America into harmonious cooperative relations; and morally we need your stimulating example. But do not force this on us. Help us to keep our self-respect and our national honor while you help us to rid ourselves of the tyranny of our caudillos, of our individualism, our graft and our inertia. Please, Mr. Great Big Yankee Man, we know we need your capital and your powerful influence and we do admire you for many things, but please, fewer marines, fewer one-sided treaties, fewer demands for economic exploitation, and more help in developing the things that have made your own fine nation great."

The way in which practical service is appreciated by the Central Americans is illustrated by the following editorial from El Diario of Guatemala (March, 1920):

"The United States has shown herself in other important ways as above the suspicions of 'dollar diplomacy' and the 'big stick.' In each of these ways there are displayed enough noble and altruistic ideas to erase jealousies and hatreds. More important than political treaties, than the solemn promises of friendship and love, than congresses and conferences, the great cultural endeavors of North America have contributed to the drawing together of the Americas. The truth of what we say is proven by the great work done in all parts of the continent by the Rockefeller Institute and evangelical missions.

"It is not necessary to mention the discretion with which these have carried on their work. No one ignores the posi:ive benefit which the Rockefeller Institute has brought ibout. Its work has not been unilateral. In combatting the 
hookworm and penetrating to the most remote parts of the tropics it has propagated the truth concerning popular hygiene everywhere. It has endeavored to teach cleanliness to the Indians, that they should understand the healthfulness of bathing, the necessity of privies, and of eating only healthful foods. The Institute has gone from farm to farm, from house to house, while its officers in the cities and more important towns have not rested a single minute in the work of examining the sick, distributing medicines and interesting a vast circle of people in its work. The results obtained could not be more satisfactory, as can be seen by the statistical tables published by the Foundation.

"Although less in evidence, but not for this reason less important, especially for our mental and moral progress, has been the work of evangelical missions. By means of ministers splendidly educated and really moral, American Protestantism, giving itself to the humanitarian endeavor of liberating our masses from their ignorance, has carried forward the splendid good news of a pure and human-hearted religion to a large part of our people.

"Thanks to heroic patience Protestant missions have attained notable triumphs. To-day seed sown is beginning to bear fruit. In many humble people a real religious sentiment, reflective and tolerant, is beginning to be substituted for the absurdities of fanaticism and the intolerance of the past. The Sunday preachings of the evangelical pastors have been, at the same time, happy means of propagating ideas against crime and vice.

"Latin America knows how to appreciate all that has come from these humanitarian institutions."

Summing up, my first hand observations in the Caribbean countries have led me to the following conclusions:

I. The economic and political life of these countries is held in the hollow of the hand of the United States. Whether or not either party likes it, modern relationships of life make it inevitable. Something very similar to a colonial problem is therefore presented.

2. The lack of recognition of this close relationship and the lack of a colonial experience and the employment of an 
PROBLEMS OF THE CARIBBEAN COUNTRIES 321

opportunist policy have led us into mistakes that made intervention, even when justified, much more resented than was necessary.

3. Failure to announce openly a definite policy and leaving matters largely to the military has led to a policy of suppression rather than of constructive helpfulness.

4. Intervention, being principally to conserve order, protect American investors and ward off European interference, the reactionary parties in the various countries are too often sustained, liberal elements are shut off from any means of effectual protest against flagrant abuses of such authorities, and the help of the interventors is too often confined to material matters, with little consideration given to educational development.

I would respectfully suggest that steps along the following lines would help in solving this important problem of developing and maintaining friendly relations with the Caribbean countries:

I. Withdrawal of United States marines from countries where they are now stationed.

2. Elimination of press censorship in countries where it is now maintained and the encouraging of free discussion both in the United States and the other countries concerned, so that the people may publicly determine and frankly avow the policies of relationships.

3. A strong department, with recognized responsibility, in the United States Government to study conditions and advise the Executive and Legislative powers concerning relations between this country and smaller nations which have become specially dependent upon us. This department could well have an advisory committee made up of some outstanding private citizens who are in a position to aid in such work. Immediate economic, educational and social surveys should be made to determine the exact situation and needs of the various countries.

4. The signing of treaties between the United States and certain Caribbean countries, based on clear consent of the people, which will recognize the sovereignty of the smaller nation and explicitly define what the stronger nation may and may not do toward giving needed help in stabilizing 
government, insuring fair elections, strengthening finances, improving sanitation and public works and developing education.

5. Special care should be exercised by the United States government in the selection of broad-minded, sympathetic officials, trained especially for the type of work they are sent to accomplish in these countries.

6. Special efforts by educational, social, philanthropic and religious foundations and organizations in the United States to extend the work to these countries, carefully adapting it to local psychology and avoiding a patronizing or "Americanizing" attitude.

7. Cultivation on the part of the North Americans of an appreciation of the history, literature, social life and problems of these southern neighbors.

\section{References}

Arguello, Leonardo: El Caso Nicaragua.

Blakeslee, Geo. H. (Editor): Mexico and the Caribbean. Bonsal, Stephen: The American Mediterranean.

Important discussions on this subject will be found in the issues of 1920 and I92I of the following magazines: The Nation,

Current History, Hispanic American Historical Review and La Reforma Social.

Inman, Samuel G.: Through Santo Domingo and Haiti. JoNES, C. L.: Caribbean Interests of the United States. LATANÉ: The United States and Latin America, Chapters III, IV, VII.

Monroe, Dana G.: Five Republics of Central America.

Oreanumo, J. Rafael: La Caída del Gobierno Constitucional en

Costa Rica.

Shoens, Geo. T.: Report on Public School System of Nicaragua. Slade, William F.: The Federation of Central America.

Schoenrich, Otтo: Santo Domingo, A Country with a Future. Ureña, Henriquez: Los Estados Unidos y La República Dominicana.

Valentine, L. G.: Meddling with Our Neighbors, Century Magazine, I9I4.

World Peace Foundation: The New Pan Americanism, III. 


\section{Chapter IX}

\section{PAN AMERICANISM VS. PAN LATINISM}

North Americans are likely to conceive of all Hispanic Americans taking the same attitude toward every question and all belonging to the same school of thought. But men in those countries differ as widely and as violently as they do in other parts of the world. Political parties are most likely to be divided into Conservatives and Liberals or Clericals and Anti-Clericals. But when it comes to questions of international relations, education, literature and all cultural subjects, intellectual circles can generally be divided into Pan Latinists and Pan Americans. This means more than that one school believes in a cultural and possibly a political entente with the mother country and the other believes in close relations with North America. It means that the members of one school have their whole philosophy of life permeated with the belief that national life will be strengthened to the degree that the glories of the Latin race, its language, its classical literature, its educational theories, its social customs and its ancient standards of individual conduct are maintained. The other school is equally sure that the strength of national life lies in breaking away from old Latin traditions, striking out into new paths, adopting new educational standards, new social customs and new international alignments, the United States being admittedly the friend to be cultivated and the example to be followed. The longer one lives in Hispanic America the more impressed he is with the fact that as between these two, the school of thought to which a man belongs affects the way he regards practically all of life's problems.

In the early days of independent life the Pan American school was most in evidence. The admiration for the United States entertained by the young Hispanic American coun- 
tries was so great that, in spite of their unpreparedness for the North American form of government, they copied it almost entirely. The admiration of the great Bolivar as well as his political wisdom are seen in the following words among many others that might be cited:

"The example of the United States, because of its wonderful prosperity, was too prominent not to be emulated. Who can resist the victorious attraction of a full and absolute enjoyment of sovereignty, independence and liberty? Who can resist the love that inspires such intelligent government, that combines at one and the same time private rights with general rights, that makes the common will the supreme law of the individual will? Who can resist the rule of a beneficent government that with an able, active and powerful head ever and everywhere guides all its springs of action toward social perfection which is the sole end of human institutions?"

Sarmiento was another of the early admirers of the United States. In his introduction to his "Vida de Lincoln," he said:

"South America lacks antecedents of government in her own colonial history, for she must not go to ask light of Felipe II or Fernando VII upon the art of governing. Nothing better would be given us by France, whose publicists can only be pardoned, like the Magdalen, for their much loving. The political school for South America is in the United States, as the sharer of English liberties, as the creator of a government absolutely free and strong, which in peace has built up the most prosperous nation of the earth and in war has displayed resources, has gathered armies, invented weapons and obtained laurels that open a new page in the history of modern war, making the ancient wars seem small."

THE PAN LATIN SCHOOL

But the leaders among the literary men of the last quarter of a century have been mostly hostile to the United States. 
The average citizen of the United States will find it difficult to believe that the Pan Latin school was particularly strengthened by our war with Spain. We think of it as the greatest proof of our friendship to Hispanic America. They think of it as another example of the hostility of the United States, a reason for a closer drawing together of the Latin races. They have sometimes gone so far as to advocate an alliance with Japan and other supposed enemies of the United States, simply because this would weaken the United States and therefore help Latin America. A part of their program has been the uniting of all Latin America in order to oppose their northern enemy, thus bringing into America the balance of power which has been the curse of Europe.

Let us pick out a few of the outstanding representatives of the Pan Latinist school, most of whom have been also very active in promoting opposition to and misunderstanding of the United States. To the North American these writers will often seem so ridiculous and childish that they are not worthy of attention. But it is a great mistake for us to ignore them, for they constitute the outstanding influences in modern Hispanic American literature. Among the writers of the school may be mentioned the ultra-radical Yankee haters like Manuel Ugarte, Rufino Blanco-Fombona, Vargas Vila and Carlos Pereyra, and the more measured critics like García Calderón, José Enrique Rodó, Federico Garcia Godoy, José Martí and Eugenio de Hostos. Most of these men have been sincere in their conviction that the United States constituted the greatest danger for the countries conquered and colonized by the Iberian nations either because of the tendency to copy the cold, materialistic northern civilization or because the North actually had designs on their national territory. Others have been swayed by personal animosities and by ulterior motives that sometimes have been clearly traceable to commercial influences.

It will be observed that there are two lines of argument used by these writers. The one is philosophical, based on the difference of race, and the supremacy of Latin culture and idealism over Saxon uncouthness and materialism. The 
other line of argument is historical, based on the imperialistic advance of the United States in the past and its alleged future designs upon the South. Probably those who hold aloof for philosophical and sentimental reasons are more easily converted than those who fear the imperialistic motives of their powerful neighbor. As a great Argentine philosopher expressed it to me in 1917 , in speaking of the necessity of all America standing together against European aggression: "By sentiment we hate you North Americans, by reason we love you." It is well for those citizens of the United States who are interested in combating anti-American propaganda and developing a real friendship with Hispanic Americans, not because Americans, North or South, are perfect but because it is better for all concerned that neighbors be friends - it is well for us to keep clearly before us these two aspects of Hispanic America's complaint against us. While we cannot admit for a moment all our critics say on either of these counts, yet there is room for improvement in both, and much room for explanation to our Southern friends where they misjudge us both as to our ideals and our practices.

It may not always be correct to link together the school of Pan Latinists with the anti-Yankee propagandists. But the following from F. García Godoy, a Dominican, written before the United States established military control of Santo Domingo, seems to represent pretty well the feelings of this school. He says there are two great dangers to Latin America :

(I) The loss of the "common soul" of all the Latin American nations, which is found in the possession of common ethnic bases, common language, common customs. But all of this common possession may be lost by the constant inflowing of exotic influences which by necessity have brought substantial modifications in this ethnic foundation and in the collective mentality. In nations like Chile and Argentina, because of the immense immigration, the sentiment of nationalism is being eradicated, which sentiment is the only thing that gives personality to these nations as distinct from Spain. It seems as though these countries are 
fortunately beginning to legislate against these tendencies.

(2) The second great danger for Latin America, however, is Yankee imperialism, a thing which the keenest minds of Latin America and Europe see as threatening the autonomy of the nations situated most closely to the United States. "In a recent book the Uruguayan writer, Luís Alberto Herrera, argues that we ought to take as our model the United States. This is the worst kind of advice. There is in the United States a different way of looking upon life from that of Latin America, and it seems to me, that since Latins are formed by undeniably diverse spiritual influences from those which have developed North American psychology, that Yankee imitation would therefore bring a foolish and harmful extension of all that particularizes and distinguishes us as a people molded by the glorious Latin civilization.

"North America's race prejudices, her utilitarianism, her lack of a certain noble and life-giving idealism, will always cause that race to remain distant from us. In the United States the immense majority of the press show prejudices entirely unfavorable to the Hispanic American people. There are a few spirits that do us justice $* * *$ but the majority of the press, every time there is a revolution in one of our countries, accuse us of being unable to govern ourselves, forgetting the good examples of Chile, Argentina, Brazil and Costa Rica. This is the reason why we should work constantly to invigorate the sentiment of nationalism and create an environment entirely refractory to imperialistic Yankee influence in our political life."

"Ariel," by José Enrique Rodó, has probably given more weight to the anti-American feeling in Hispanic America than any other piece of literature. It is one of the great classics of the South and because of its elegant style and the literary merit of its author its influence has been tremenlous and its teachings have been exaggerated. In this book the author warns his fellow-men against imitation of the United States. Though he acknowledges the contributions that the United States have made toward modern civilizaion yet he believes that we are a purely materialistic nation 
without a soul and that it behooves the Hispanic "Americans to guard their idealism lest it be destroyed by our influence. $\mathrm{He}$ concludes by expressing the hope that "the spirit of that titanic social organism, which has thus far been characterized by will and utility alone, may some day be that of intelligence, sentiment, and idealism."

Rufino Blanco-Fombona, in writing an introduction to the book, "El Crimen de W. Wilson," says: "Here Wilson is selected as an illustration of the Yankee policy in its relations to Latin America." The great lesson of this book consists in revealing that which he says Latin America should never lose sight of: That it is not Wilson or Taft, nor the ridiculous Roosevelt, not any president, not the Republicans nor the Democrats, not any party present or future, that is the enemy of America, but that the traditional enemy, present and future, of America is the Republic of the United States." Here are two races facing one another, one of Latin origin, the other of Saxon origin; two Americas, one born in southern Europe, the other in northern Europe; two conceptions of life, the idealistic and the Sancho Panza; two sects, Catholicism and Protestantism; two social ideas, individualism and solidarity; two civilizations, that of the Mediterranean and that of the region of the Northern Lights.

García Calderón discussed the difference between the two Americas as follows:

"There exist two forms of Americanism, Saxon and Latin, which it is impossible to reduce to a unity. The republics of the South have a tradition and history which are also American. They are American on account of the territory in which the political life of these democracies is developed, with greater reason than is the North, where the conquerors annihilated the indigenous races.

"We call 'American' the Iberian nations of whose development the Indians and Meztizos are authors. On the other hand, Americanism symbolizes the new life, undisciplined and spontaneous, in opposition to harmonious European culture. The United States are considered by refined Europeans as a people hostile to art, to form and to grace. These 
barbarous people without history, conquer with accumulated gold and prosaic struggle, the ideal human riches. North Americans are those transatlantics whom Abel Hermant describes in his notable satire: 'They collect in palaces of bric-a-brac, the treasures stolen from Greek masterpieces and their audacious canvases of the imperious Icons from Moscow and jewels from Florence.' This Americanism is reduced to the worship of gold, to violent monotony, to the love of the grotesque, to utilitarianism, which measures with a common leveler - the dollar - the virtue of Lucretia, the talent of Newton and the beauty of Venus de Milo.

"The Yankees of Hermant are 'great athletic and rosycheeked babies' who come to Europe in order to acquire genealogies and to oppose their turbulent youth to the glorious age of the western nations. They believe that they speak better than the Saxons of Europe, "the pure English language.' They love excessive finery. "They aspire to gain all of the records for spending, for noise and for scandal. 'In America,' says Henry Shaw, the American representative, 'we generally have catastrophes worthy of the name, 'the most terrible catastrophes of the world.' And so with reference to floods, fires and multitudes. Compared to North Americans those of the South appear a mature race. They are less youthful and less ingenuous. Instructed by French and Spanish books, under Latin influences, they do not pretend before Mother Europe the irreverent attitude of the enriched Yankee, the burlesque, the irony, the light periodicalism which Roosevelt attacked in the Sorbonne, in the name of optimism, and of the strenuous life."

Again he says: "Pan Americanism has a territorial significance. Geography and commercial advantages contribute to it. But Pan Iberianism is a tendency of race. It restores old bonds of a moral character which have been forgotten because of time.

"However, Pan Iberianism will with great difficulty become a unified force. Contrast the force of the intellectual minority with the ignorance of the Spanish people concerning Latin American subjects. The Latin American is a person to disdain. In vain emigrants return loaded down with gold. The nation looks down upon those colonies that oppose with 
their abundance of riches the proud poverty of Hidalgo. The new continent is not yet popular in the old world. It is far away. It is very indistinct. Against these young preachers of fraternity some writers of Cuba have developed an exaggerated nationalism. Fernando Ortiz, professor in the University of Havana, finds in Spanish ambitions a plan to reconquer America."

Among the choice specimens of indictment by Rufino Blanco Fombona is the following:

"The people of the United States, before their war with Mexico were a people without militaristic and imperialistic ambitions, the model of the home of civil liberty. All of South America admired them, with the same ardor with which to-day they detest them, because of their fraudulent elections, their trusts, their Tammany Hall, the loose customs of their women, their treachery in business, their ridiculous, wordy and symbolical Colonel Roosevelt, their shirtsleeve diplomacy, their professors in universities who write concerning Latin America with supine ignorance, their sinking of the 'Maine,' the secession of Panama, the taking over of the finances of Honduras, the taking over of the customs of Santo Domingo, the blood which they spilled and the independence which they annulled in Nicaragua, the revolutions which they fomented in Mexico and the disembarking in Vera Cruz, their claiming of 8I million pesos from Venezuela, when in reality she only owed them 2 million, their recognition of a foreign arbitration, their demanding of the Alsop claim in Chile, their little-disguised desire for the Galápagos Islands of Ecuador and the Chinese Islands of Peru; the daily affirmation that the Argentine statesmen should not be believed; the pretension of preventing Brazil from a valorization of her coffee; for the seizing of Porto Rico; for the Platt Amendment of the Constitution of Cuba; for having converted her cables and her periodicals into an office to discredit all and each of the republics of America; for their aggressive imperialism and all their conduct in respect to America, from the last half century up to the present." 
A leading Brazilian journalist, Madeiros d'Albuquerque, thus unbosoms himself of his North American impressions upon returning to Rio de Janeiro after a visit to the United States during the war.

"I return from the United States with much enthusiasm for England, Italy, France, Belgium, Japan, and perhaps above all, Mexico." $\mathrm{He}$ accuses the United States of "fomenting revolutions" in Mexico, and declares that: "Brazil is considered by the United States only as a possible future colony. The United States wants to obtain as part of the payment of the debt of France and England a bond for Brazil's debt to those powers. On the day this is realized, Brazil will be sold to the United States, which, on the first occasion when we fail to meet the interest, will do to us as she has done to Central American nations." Señor Albuquerque belittles the part the United States took in the late war, attacks the Monroe Doctrine, ridicules President Wilson's activities at the Peace Conference, and concludes by saying: "The United States is incontestably the Prussia of to-morrow."

Most Colombians have a poor opinion of us and Señor J. M. Vargas Vila, the novelist, is certainly no exception. The title of one of his latest books well describes its contents, the volume being called "Against the Barbarians. The Yankee-Behold the Enemy." That Señor Vila handles us without gloves will be seen from the following excerpts from his coruscating pages:

"The Yankees are giving themselves over to the division and plunder of Latin America-the Yankee has chosen well his hour, this tragic and crepuscular hour, in which none can go in aid of the peoples he is devouring; the Yankee has exploited the European War as if it were a mine. Why not make Latin America see what, in reality, this race and people are? A lustful race, hostile and contemptuous, a countless people, spurious and cruel, insolent and depreciatory toward us, with a monstrous idea of their superiority and an unconquerable desire for conquest. They are the men of the North, the descendants of the Norsemen, of the pirates 
of the Baltic, who in roughly built boats crossed the black waters under a misty sky, to begin the pillage of peoples; they are the descendants of the worst beggars of Albion and Germany, who emigrated to America, became powerful, and who to-day feel in them the vibrations of all the atavisms of their adventurous race; what happened in Cuba was but the prologue of a drama-the conquest of America. The Yankee race, proud and mean; a race of sensual dreamers, avaricious and cruel. It is necessary to combat the Yankee or frankly declare ourselves his slaves; it is necessary that we unite ourselves against the Yankee; it is necessary that from Mexico to Cape Horn there be but one brain to consbat him, one arm to resist him, one heart to hate him. Hate for the Yankee should be our motto since that hate is our duty."

One of the most widely read magazines of Latin America is Nuestra América, published in Buenos Aires. The leading editorial in the September, I920, number is as follows:

"Spanish Americans, free men, soldiers of a real democracy, dreamers, poets, haters of all that is mercenary! Ye in whose spirits are amalgamated the courtesy of France, the honor of Spain and the artistic spirit of Italy, ye, who turn your steps toward the day of equity and of justice, hear me! A free nation, blood of our blood, a nation of small territory but great soul, Santo Domingo, quivers in agony under the claws of a covetous, greedy, mercantile land,- - a conquering nation which makes its conquests with the dollar, not the sword, for that is too noble for it and would be dangerous. Santo Domingo bound down a prisoner in the snares of base intrigue, stretched for it with all cunning, is in desperate straits, crying out for her threatened independence. The statesmen of that sister nation of ours, the journalists, the writers, all her sons, indeed, have sent forth a cry of alarm to their brethren, a cry that calls for our help, our cooperation. Her cause is ours, it is that of every free nation of Latin America. Let us hear them, let us hasten to join their ranks, let us with them lift up the cry of protest. Mexico, torn and bloody, is a palpable example of 
what North American greed means, the first victim in a great conspiracy of intrigue.

"We must forget for an instant our immediate interests and turn all our attention to the painful, tortuous drama which is developing over there in that land no longer free of Santo Domingo. It is a member of our family which the invading giant is chastising. Is it possible that in the presence of such an affront we should remain indifferent? Are we peoples organized into nations or are we mere tribes? If we are peoples let us lift up our protest; let us withstand the mighty enemy with the force of our reasoning. The convictions of great spirits are more powerful than dollars and naval guns.

"Brethren of America, let us unite. Let us lift our arms in defense of the Latin republic whose honor is being wounded by the greedy Yankees."

The most persistent and most active of all the Yankee haters of Hispanic America is Manuel Ugarte of Argentina, now living in Europe. He has not only written much on his favorite theme, but has many times toured America from Punta Arenas to the Rio Grande-indeed he once came as far as New York-lecturing on the necessity of all Hispanic America getting together to conserve their Latin inheritance and resist the onrush of the North American. He has recently issued a new edition of his famous book, "El Porvenir de la América Latina," in which he brings up to date his attack on Yankee imperialism, showing how the World War has augmented its danger.

"When I published this book in I9I I," says Señor Ugarte in his prologue, "Spanish America had just suffered the humiliations of Nicaragua, was writhing under the amputation of Panama and had fresh in mind the memory of the war of greed and felony which compelled Spain to strike her colors in the last of her dominions, thus presaging a painful supplanting of her spiritual influence in the New World.

"Nevertheless, there abounded in the republics across the 
sea ingenuous politicians who, despite the evidence in the case, despite all logic, took me to task for my zeal, spoke of how disinterested the United States was, and proclaimed the necessity of a fraternal policy, because, they averred, 'it is unquestionable that only highly important geographical and strategical necessities have caused that country to commit certain acts which are the limit of its advance and the beginning of a policy of conciliation.'

"Since then we have looked on, restraining our anger, while the United States has sought to invade the very heart of Mexico through El Paso and Vera Cruz; later we witnessed the unspeakable outrage against the little republic of Santo Domingo, governed at present in the most arbitrary manner, against every principle of right and justice, by a captain of the United States Navy. We have followed, finally, the various incidents in the manœuvre of intimidation and international browbeating whereby, during the war, the attempt was made to break down our autonomy and to compel us to serve foreign interests. And to-day, when I am publishing another edition of this book of combat, I must unfortunately bear witness to the fact that the ingenuous politicians of I9II, far from having disappeared from the Spanish-American stage, exist in greater numbers in 1920.

"Our nations of Spanish origin, those that are flourishing as well as those that are stagnant or exhausted, show more clearly every day their helplessness before the wave that is submerging them, surrounding them, or threatening them. This is true of some because, swollen with pride and boastfulness on account of their rapid rise, they despise the rest, forgetting that all of them, compared with the great nations, are held down by their weakness to the same orbit of rotation. It is true of others because, governed with an eye to local rivalries and not to higher interests, they are under the thumb of little groups which deem themselves the Alpha and Omega of life, which possess vanity in inverse proportion to their lights and pride in inverse proportion to their radius of action; it is true of others because all they retain of their autonomy is the harmless toy of a Presidency and Legislature for giving employment to the interminable caravans of claimants who clog the anterooms of Washing- 
ton, begging the semblance of power in exchange for a shred of their nation's flag.

"The passion to make money, the voracity of the factions which fight against each other for supremacy and artificial quarrels about frontiers between sister nations which, though they have not colonized what they already possess, claim, through sheer greed, arid desert territories or inaccessible peaks, are all that occupy the minds of the Latin Americans.

"This favors the economic, intellectual and moral infiltration of the United States. The United States makes its appearance at all the crossroads in the daily life of Latin America, asserting its prestige in all sorts of ways, from the inevitable statue of Washington to gifts of books to libraries, to say nothing of moving pictures and automobiles. And the echoes of the activity of other Spanish-American countries are only heard now and then and in a manner calculated to engender loss of prestige."

He paints Mexico's experiences with her great northern neighbor in these words:

"Predestined by reason of its geographical situation to be the most direct road for North American exploitation, yet prepared by reason of its large population, wealth and civic feeling to face the formidable crisis, it has gone through every phase of the struggle without once losing heartfrom war, with its unhappy outcome, from the territorial amputations of 1845 and 1848 , to the keen and subtle duel of diplomatic notes which has characterized recent years.

"The case of Mexico is, granted differences of distance and intensity, the drama of all Spanish America. Broken up and dispersed, our republics are confronted with the dilemma of submitting like Cuba or resisting like Mexico, of accepting a protectorate with all its concomitants of humiliation or condemning themselves to a heroic and desperate resistance. Only spiritual union and diplomatic accord among all of them can engender that equilibrium of power which should safeguard future development."

Finally Señor Ugarte, in despair, points to what even so 
sane a writer as García Calderón has suggested as the way out-an alliance with Japan.

"What cannot be denied," he says, "is that Japan will always be a cause of worry for North America. Let us take advantage of this, let us follow sympathetically the forward push of the Japanese nation, which, formerly threatened, has now, by a prodigious effort, succeeded in freeing itself from foreign influences, in affirming, in a way precluding discussion, its autonomy, and in undertaking upon the Asiatic Continent the task of emancipation which is beginning to counteract the ambitions of Europe. Nothing could be more sympathetic to Latin Americans than the political personality of the great nation-centuries old, yet young at the same time-which imparts to us lessons in optimism, showing us how a lethargic community can become transformed into a power which ventures to bandy words with the tyrants of the universe."

Some thirty years ago a Brazilian writer, Eduardo Prado, wrote a book called "The American Illusion," which has continued until to-day to be a classic in Latin America. This book expresses the opinion that the rest of America should unite against the United States in order to protect themselves from the North American nation. The following is a summary of his argument to show that the United States has continually pursued a hostile attitude toward Latin America :

"North America did not help Latin America in its struggle for independence. William Burke and Canning were the first Anglo-Saxons to defend Latin American independence; in I8I9 the American government refused to receive consuls appointed by Venezuela and by Buenos Aires. Not until March 9, I823, did she recognize the independence of the Spanish republics; the Monroe Doctrine was promulgated under the influence of England; the United States was hostile to any country that wished to abolish slavery. Haiti was the object of American hatred. Hamilton of South Carofina declared in Congress that its independence should not be tolerated in any form, and Hayne demanded that any 
country that should recognize the independence of Haiti should have its relations with the United States cut off; the United States worked against the independence of Cuba, fearful that this would promote the abolition of slavery; the United States was the last to recognize the independence of Brazil ; insolent messages were written by President Jackson referring to Brazil and other South American nations; the Secretary of the Navy in 1830 insisting on the enlargement of the naval forces, said, 'This is necessary in order to defend our permanent interests among those unstable and incapable governments;' in I 830 the United States was the only government in the world which recognized the usurping and absolute King of Portugal. The United States bombarded the Falkland Islands in $183 \mathrm{I}$, then the possession of Argentina, taking the part of a few adventurers there, disembarking troops, killing many colonists and destroying houses and crops. She refused satisfaction on the ground that the ownership of the islands was in dispute. She later allowed England to take these islands in spite of the Monroe Doctrine; the United States has never appealed to Latin American countries to settle difficulties of the United States by arbitration (this was written before the United StatesMexico mediation); the injustice of the Mexican War is recognized by many American historians (Bancroft quoted) ; after the Civil War President Grant and other leading North Americans helped to exploit Mexico; the filibuster expedition of Walker to Central America was recognized by the United States Government and Walker was protected in every way. President Buchanan sent a telegram to a meeting where Walker was to speak in New York, saying that the heroic work of Walker excited his admiration and solicitude; in I854 Nicaragua was bombarded by the United States forces and the city of San Juan was burned; the United States protected all kinds of abuses in Panama, and aided the revolutionists to free themselves from Colombia; in spite of the Monroe Doctrine she failed to help South America when Spain endeavored to reconquer her colonies in I860; the United States intervened in the settlement of the Chilean Peruvian War, helping Peru in order to protect her financial interests; the 'Water Witch,' an American commercial boat, 
disobeyed the laws of Paraguay and was fired upon by the national authorities. The United States sent a fleet of twenty ships to demand damages. Argentina secured reference of the case to arbitration which declared the owner of the 'Water Witch' had no claims whatever."

The Pan Latinists have a number of reviews and continually publish books and pamphlets and give lectures calculated to advance their cause. No one could object to a positive program of promoting friendship between the Latin peoples. Indeed such a work should receive the encouragement of all lovers of peace. But the present program is largely one of abusing and misrepresenting the United States. A sample of this is found in the work of a magazine that has been published in Spain for twenty-seven years and whose object is explained by its name, Unión Ibero-Americana. In the number of October, I913, the following article appeared, which is quoted as a sample of those that are continually put before the Hispanic American people.

"It is certainly true that the so-called Yankee Peril has been manifested in a new way since 1898 , when the ruling party of the United States, called Republican, greatly aggrieved Spain. The attacking of Spain, although it was most monstrous and unjustifiable, was soon eclipsed by the happenings at Panama and Nicaragua. The necessity that the Ibero-Americans unite, in order to place a barrier before the enormous ambitions of the Yankees, has its foundation in the opinions of the politicians of the United States themselves. The least aggressive of the Yankee imperialists, Mr. Elihu Root, when he was Secretary of War in the Cabinet of McKinley, replied to the delegates from Porto Rico, who visited him with all humility to ask for North American citizenship, the following: 'Between the Latin Americans and us there does not exist, nor can there exist, anything in common; although our desires are very great they are not sufficient to fill the chasm which separates us.'

"Mr. Root speaks well, for there is a deep chasm that separates morality from immorality. The same Mr. Root, 
the pacific imperialist and angelic citizen, said in an address given in New York on the 24th of August, 1912, before the Chamber of Commerce: 'It is a question of time until Mexico, Central America and the islands, which we do not possess in the Caribbean, shall come under our banner.' Let the English, the French, the Hollanders, the Danes, who own islands in the Caribbean, take notice!

"Ex-President Taft, the flower of the imperialists captained by McKinley and Roosevelt, in an article, called 'Reply to the Scientific and Political Critics of the Canal,' inserted in a North American review and reproduced by the Star of Panama, said the following: "The day is not far away when three banners bearing the stars and stripes will point out three points equidistant in our territory, one on the North Pole, another the Panama Canal, and the third the South Pole. All the hemisphere will be ours in fact, as in point of superiority of race it is already ours morally.' All that Mr. Taft did here was to paraphrase the well-known sayings of Senator Prescott, written in 1838 , concerning 'The Origin of the United States,' when he said: 'The starspangled banner will float over all Latin America as far as Tierra del Fuego, the only limit which we recognize as the ambition of our race.' Prescott spoke clearly and called things by their real names. Lodge presented to the Senate at Washington, in March of I9I 2, a proposition which was seconded by Senator Walsh, that no Latin American nation should cede or lease the least part of its coast without the permission of the United States.

"On the I 4 th of February last the proprietors of the large daily, The New York American, directed the following questions to several Latin American presidents: 'Do you not believe that the United States would be justified in restoring peace in Mexico? This does not mean that a permanent occupation is intended or desired. Please give us your opinion.' Concerning such an original inquiry and dangerous investigation, the President of Colombia, Dr. Carlos E. Restrepo, replied in the following virile and dignified terms, through his secretary:

" "The President of Colombia believes that every intervention in the internal affairs of another nation is a violation of 
the sovereignty of the latter, and therefore, a violation of the rights of and an attack on international justice, the practice of which is the greatest desire of the Latin American nations.' The Presidents of Ecuador, Chile, Brazil and other nations replied in a similar way. They unanimously condemned the threatened intervention of the Yankees in Mexico.

"The international attitude of the Yankees has never been a model for us, for it is always full of shadows and ugly places, and a comparison of it with that of the Latin American republics favors these latter in a number of points. Some eight years ago one of the most profound English sociologists, a former professor of history in the University College, London, speaking of the dangers of the policy of the United States towards Latin America, said: 'The United States is the most disordered and most lawless country in the world. Roosevelt is not able to control the mobs that burn alive the negroes. No one is punished for these atrocities. One of the reasons why orderly North Americans congregate in Canada is in order to be in a country where law and order prevail.'

The alleged quotations from Mr. Root and Mr. Taft and other statesmen, in this article, are so evidently false that we should suppose that publications of them would do little harm. But what are the actual results of the publication of such statements in Latin America? A very serious review, the Revista de Paraguay, publishes this whole editorial and adds :

"Without accepting unconditionally all of the deductions which this distinguished author wishes to draw from his work, we must recognize the undeniable fact that this is certainly not all 'pure literature,' and here are revealed profound facts, which are being discussed here and there in all parts of Ibero-America in these later times. It has only been a few weeks since the Argentine champion of these same ideas, the brilliant writer, Manuel Ugarte, brought together in our theater the young people and the intellectual circles before whom he expounded, amidst enthusiastic applause, the 
good news of the rapidly developing crusade against Yankee imperialism."

\section{ANTI-AMERICAN PROPAGANDA}

The last quotation from this article, referring to what the English friend said, brings up the way that foreigners in Latin America often foster and use anti-American spirit for their own benefit. Some little while ago, just before the Boston Chamber of Commerce delegation reached Buenos Aires, an English newspaper stated that in all probability the ultimate purpose of the tour was to open the way for eventual annexation to the United States. "Give us your business," the other foreigners in Latin America say, "concessions for your railroads, your mines, etc., for we cannot secure your territory ; but the United States will use commercial advantages to take your territory itself."

The largest part of this kind of propaganda has, of course, been carried on by the Germans. They have not stopped at any means to turn the hatred of Latin America toward the United States to their own advantage. Where this hatred has not existed they have hired people to develop it. Just after the United States and Brazil entered the World War, there appeared a book in Argentina, which had a cover which told the whole story of the book. On this cover the American eagle was represented as holding the Brazilian flag in his claws and swooping down upon Argentina. The book was entitled "Our Next War." It argued that the United States had now been able to secure Brazil's cooperation against Argentina and that the whole desire was to crush Argentina, which would very soon find itself attacked by these two northern countries. The book created such a sensation that the Argentine Government found it necessary to investigate concerning responsibility for its publication. It found that a Spaniard had written it and the money for its publication had been furnished by the German Government. Argentina made an official explanation and apology :o Brazil for the appearance of the book.

Much concerning the source of such anti-American propa: janda has been shown by the study of propaganda methods 
as a result of the World War. Klaus Wagner, a German writer, spoke as follows in 1906 :

"Slowly, not hastily, we people of Germanic blood must proceed in the settlement of the lands which are to be ours in the future. $* * *$ By right of war (conquest by arms) the non-Germanic (people) of America and Great Australia must be settled in Africa. $* * *$ By right of war we can send back the useless South American Romance peoples, and the half-breeds to North America. * * * The lands will be settled upon by people of Germanic blood, the non-Germanic inhabitants driven into reservations, or at best to Africa (Algiers, Egypt, Morocco, Tunis).'

The French writer, Maurice de Waleffe, begins his book, "The Fair Land of Central America," with the following: "The United States have made up their minds to conquer South America. Washington aspires to become the capital of an enormous empire composing, with the exception of Canada, the whole new world. Eighty million Yankees want to annex not only 70 million Spanish Americans but also such mines, forests and agricultural riches as can be found nowhere else on the globe." Such authorities are often responsible for articles that appear in the magazines and daily papers, like one in a Lima paper with the following headline: "North American Excesses; the Terrible Lynchings; and They Talk of the Putamayo."

In the preface of a volume published in 19I4, entitled "Labor Hondureña por la Autonomía de Centro-América," the alleged publisher of which was "La Liga de la Defensa Nacional Centro-Americana," is the following: "Among other documents of real importance this publication includes a large number of records of protests raised by almost all the towns of Honduras against Yankee imperialism in Central America. The purport of the volume is naïvely revealed, when (page 330) it is stated that:

"The governments of Central America should subsidize transatlantic steamship lines to bring to Central America 
from old Europe its manufactured products, that are more polished, finer and of better quality than the American goods and are, moreover, lower in price; because artisans in the United States lack the classic style, and their wages are high, consequently the prices of their products also are high."

Dr. J. A. Arias, of Honduras, also points out the results of sensational news stories:

"Our own citizens of Latin America have aided the enemy in this work of fomenting prejudice against the United States. One news service in the United States cabled daily to the Hispanic American newspapers items that were mainly about crimes committed, divorces and scandals and follies of society. Cultivators of hostility toward the people of the 'Octopus of the North' cited this matter as proof that those people were criminals, salacious and ungodly. Protests brought from editors the answer: 'Why should we imagine that this matter is unfair? It is chosen by American editors for a press association. Would they send it if it were not true?" "

North Americans are often their own worst enemies in producing prejudice. Publishers in the United States have helped the anti-American propaganda to the injury of those manufacturers, carriers, and merchants whose money for advertising helped to pay contributors, editors and printers of jests, quips, and stories, articles on international affairs, books of travel and of description, and novels intended to amuse, but which do little more than incense the people of the South.

Another class of propaganda against all foreigners, but used particularly against North Americans, is that which the well-known Mexican writer, Francisco Bulnes, calls "Jewish hatred," that is hatred of heretics. As Bulnes says:

"The clergy preaches this persecution, this hatred, this faith $\mathrm{n}$ the greatness of Mexico, not attained by developing our -iches, but by expelling heretics. As the Bishop of Puebla said in a sermon: 'If all heretical Mexicans and foreigners 
would leave this chosen nation of His Divine Majesty we would not be saddened again by the pests and famines which God has visited upon us.'

The United States is often held up to the faithful-by the Catholic clergy as the greatest enemy of Latin America because it is the greatest Protestant nation. Protestant missionaries from the United States are reported as secret emissaries of their government, working for the subjugation of the fatherland. Since North America is heretical it has no soul, no culture, no morals, nothing worthy of imitation but everything worthy of fleeing - so the faithful are told and retold, with the lesson emphasized with exaggerated stories of Yankee imperialism. All who are familiar with Latin American life know that no treatment of anti-American propaganda could justly omit the very strong influence that the clergy-often foreigners themselves-have exercised for generations against North Americans.

Since American shipping has taken a prominent place in the latter days in Latin America, foreign agents have often been able to capture the agency of these ships and work against the United States from the inside. They may be careless about expenditures, they may play into the hands of their fellow countrymen to overcharge for supplies, fuel and repairs; some of these agents actually report that the North American boats are not seaworthy, that the United States cannot possibly become a maritime power, that this Government has no right to engage in the shipping business and deprive other foreigners of their legitimate income, which has been their living for all these years. American ships need American agents and crews, who should be selected with the greatest care both for their professional ability and for their representative American character. Carelessness, wastefulness, dishonesty, immorality, are quickly seized upon by the anti-American propagandist. The conduct of sailors ashore has always been a problem. It should have careful study and such agencies as the Young Men's Christian Association, established in foreign ports, should be encouraged to carry out large plans for our seamen. A Chilean once told the writer that he supposed 
Americans generally ate with their feet on the table, since all those he had ever seen in his little port town were sailors who followed that custom in restaurants. Probably nothing has done so much to bring Uruguay to its staunch friendship for the United States as the fine conduct of our sailors who visited that country with the fleet in 1917. Most of them were fresh recruits from our colleges and business organizations of the middle west. As one citizen expressed it : "IVhen the United States sailors used to come here, the policemen would take to the trees. But these fellows are real missionaries of North American culture. I haven't seen one of them drunk on the street. Our mothers have suspended the rules, and allow their daughters to promenade or dance with any man who wears a United States uniform."

A sample of a common commercial propaganda, legitimate withal, now carried on by France is shown in an article in the Paris Review, by D. Lafond, who speaks as follows concerning Pan Latinism:

"Just as soon as the discussions concerning peace and the establishment of order have been terminated, the conquest of the rich and unexplored markets of Latin America will be the object of an intense struggle, in which the United States and the central European powers will take part. France is disposed to enter this contest, bearing the banner of Pan Latinism, and in this struggle will compete not only against Germany but also against her allies, England and the United States. When we speak of these republics we do not use the term in an academic sense but as an expression of a strong racial sentiment which more and more day by day is emphasized. Brazil, Argentina and Uruguay are dominated by Anglo-French capital and by French ideas. The racial idea in the sentiment of common culture and conditions is the corner stone of modern politics. Pan Slavism, Pan Germanism, Pan Americanism, why not add to this list Pan Latinism? Europe is overcrowded. In a short time the same will liappen to the United States. There is left only South America whose population was $15,000,000$ at the beginning of the nineteenth century and has been multiplied by six. The European War has created a new situation. France, Ger- 
many and England are eliminated and the United States has not prepared itself to occupy the vacant place. We must therefore prepare to fight for the markets of South America. Latin American commerce can be secured for France because the Latin Americans have a point of contact with the French which they have with no other people. Latin Americans have a center of nerves which are moved principally by sentiment. A persuasive and eloquent argument is what is needed to bind them to us."

In similar vein is a long article by Georges Lefor, in a recent issue of Revue Minerva, entitled "Capturing Latin American Markets." He says:

"Latinity is not simply a vague literary expression. It is a practical thing as regards many economic and political matters. The Latin republics of America feel the affinity of race and profess sympathy for the Latins of Europe. Argentina, Brazil and Uruguay, where there is so much AngloFrench capital invested, influenced by French ideas and Italian workmen, will not delay long in drawing near to those European nations which populated, civilized and enriched Latin America, that is France, England, Italy and Spain, and exclude others from her market, for Latin superiority in South America is absolute from every viewpoint."

Spain is pushing even harder these claims of kinship to aid commercial and cultural relations. An example of Spanish enthusiasm along this line is the organization of the order of the "Knights of Hispanic America." The object of the order is to foment friendship between Spanish-speaking countries by means of intellectual exchange, public lectures, founding of Pan Hispanic libraries, the sending of students to Spain, the publication of school texts from which will be eliminated those concepts which engender hatred of Spain, and finally the organization through chambers of commerce, of expositions where exhibits of Spanish and Spanish-American products will be maintained, in order to develop commercial interchange.

The most far-reaching of these efforts is the establishment 
of "El Dia de la Raza" (The Day of the Race) on the anniversary of Columbus' discovery of America, when Spanishspeaking people both in Europe and in America are asked to celebrate the glories of Spanish history and letters and pledge themselves to maintain these noble traditions. The day has rapidly grown in popularity and is now declared a legal holiday in most Latin American countries.

Those who are particularly interested in relations between Spain and her former colonies are likely to belittle the appeal to Pan Latinism and claim that the movement should be confined to Pan Hispanisn. They also object to the term Latin America, claiming that it should be rather Hispanic or Ibero-America, because the people of Southern America did not come from all Latin countries, but only from Spain and Portugal. If objection is made that the term Hispanic America leaves out Brazil, they reply that it does not, since Hispania is the ancient name for all the Iberian Peninsula. But the writer has not found that the Brazilians admit that the term Hispanic America includes them. For that reason and also because southern America is certainly closely akin to France in culture, if not in blood, and is constantly being drawn closer to Italy through immigration, the term Pan Latinism has been employed rather than that of Pan Hispanicism, although the latter is insisted upon by certain societies and publications interested in this field.

\section{THE SCHOOL OF PAN AMERICANISTS}

North Americans will be deeply gratified at the appearance of a school of authors and statesmen who frankly recognize the mistakes in the judgments concerning the United States and earnestly plead for a change of attitude on the part of their fellow countrymen. President Brum of Uruguay has expressed one of the reasons for this new attitude, when, speaking at a banquet in honor of Secretary Colby at the government palace in Montevideo, he recalled his visit to the United States in 1918, where he saw the nation's war effort and could feel "that all that powerful energy was not set in r. otion for the sake of avenging a direct or personal offense, nor to obtain material advantages, nor to extend farther the 
boundaries of the homeland, but for humanity and to establish amongst nations the supremacy of justice for the sake of, as President Wilson would say, 'our sons and the sons of all men in the world, that they may live free and peacefully." "'

"And it is this," continued the President, "which has raised your country to the highest degree; which has made it great, because of the strength of your idealism; which has made it sacred as the bulwark of the noblest international principles; which has bound it more to its brothers of America, who, like it, have grown and who breathe the same impulse of liberty and who consider its glory as their own glory, as a reflex of the great Columbian country."

One of the most remarkable of these new advocates of friendship with the north is Jesús Semprum of Venezuela, who has recently spent some time in the United States and come to know their better side. Writing in a recent issue of Cultura Venezolana, he makes a study of the reasons for the feeling of dislike and contempt felt for the United States, due at first to dissimilarity and misunderstanding but principally to the Spanish-American War. Here are a few extracts from his remarkable article:

"We who opened our eyes to intellectual life with the first years of this century began to breathe an atmosphere by no means friendly to the 'Yankees.' The inevitable defeat of Spain awakened a profound moral echo among our peoples. Envenomed by a multitude of purely rhetorical phrases and falsehoods, we saw in the triumph of 'Yankeeland'-as we wrote, with a certain innocent bitterness to which we strove to communicate a deeply sarcastic air-the victory of the strong over the weak, of the lusty barbarism over the delicate and exquisite being. Thick clouds obscured our vision and prevented our penetrating the magnicent significance involved in the Spanish-American war and the liberation of Cuba, Puerto Rico and the Philippines. Our somewhat extravagant love for good Spain prevented us from informing ourselves regarding events as they were. We were bewitched by the old legend of chivalry, and we beheld Spain 
symbolized in the gaunt silhouette of Don Quijote, who, lance in socket, appeared in the nineteenth century to hurl himself upon a formidable ruffian, an enormous brigand, the forcer of damsels. Properly speaking, this also was not a spontaneous vision of our minds. We conceived it by reading the masters of our generation, the great South American writers who preached to us contempt for, and hatred of, the 'Yankees,' not only as a political concept but also as an esthetic canon. The North Americans were rude and obtuse Calibans, swollen with brutal appetites, the enemies of all idealisms, furiously enamored of the dollar, insatiable gulpers bf whiskey and sausages-swift, overwhelming, fierce, clownish. Thanks to their strength, they had set their feet upon Spain : chivalrous, romantic, sweet, weak Spain. Even those wasters who had not felt the greatest sympathy for Spain, those who owed all their culture to France, Germany, England, and even the United States herself, spoke to us bout the North as a country of gigantic and horrible sons, worshipers of the golden calf, rich, yes, but stupid and zude."

"Such a fabrication was, at all events, easily answerable, hot to say clearly absurd; but we had our heads filled with bad dreams, like good Alonso Quijano, and we took for -elentless robbers what were innocent and useful windmills. "Therefore is the present moment crystalline, because the storm of war, with its frightful profusion of thunderbolts, has cleared the moral and intellectual atmosphere of our imes of those dread clouds that closed to our eyes the hisorical perspectives, which prevented us from contemplating what was in reality occurring beyond the Caribbean, in the and of the north.

"Caliban has disappeared. The furious barbarian vanshed with the clouds of hallucination that befuddled our prains, and in its stead appears Ariel, that same aërial genius -clear, harmonious - who charmed the dreams of our youth vith the music of his flute. We comprehend now that the hen of yesterday were mistaken; and that, guided by I know ot what hidden prophetic force-by inexplicable vanity, perhaps-we attributed to ourselves-we South Americans -the rôle of marvelous Ariels ; and we assigned to our neigh- 
bors of the north the lamentable function of coarse Calibans. For the sentimental bitterness of the Spanish defeat created in us an enduring hostility toward the north. Kindly disposed toward the weak victim by a generous sentiment, which, in reality, honors Spanish America, we were not satisfied to proclaim our sympathy for Spain, but the literature of the south must consider itself under obligations to manifest dislike and even aversion for the republic of the north.

"Transcendental Hispanicism is destined to acquire living and fruitful force upon the day when it is set aright in the path of mutual comprehension and tolerance, which seems still to be somewhat remote. Therefore it is necessary that we cease to ask of Spain the examples she possessed one day, and which she to-day longs to renew with the intense aspiration of her best wills and intellects. Simultaneously it is necessary that Spain shall not demand of Americans those profound and serene virtues that can only spring up in an atmosphere enriched by ages of civilization. Loving Spain, we can, and we ought to, draw near to different kinds of culture, in order to improve and enrich our minds, because by this means shall we contribute to strengthening ourselves for future undertakings. It is therefore important to rid ourselves of the prejudices which our mistaken Hispanicism created and fostered for many years, since in Spain herself many good Spaniards applaud without stint what is admirable and praiseworthy in the United States. It is the hour for ridding ourselves of the tone of contempt or sarcasm that has prevailed for several years in southern literature whenever we referred to the north.

"What separates us from the Yankees, to be brief, is nothing but our indolence, which is incapable of engaging in a strong effort to comprehend the spirit of that wise, prudent and generous people which has already solved the essential problems of the future, or is on the eve of solving them, with enviable success. Our rich men could learn from the multi-millionaires not to consider themselves in reality as other than the transitory depositaries of the fortunes their efforts or destiny placed in their hands, as simple administrators of the possessions that Providence stored in their 
vaults, and which they ought to turn to account for the benefit of the commonwealth. Our believers might well be informed of how there the religious conception, the creed, is considered as something sacred, which does not hinder men from fraternizing, but rather compels them to fraternize, with the sectaries of a different religion, the case having occurred of Christian pastors and even Jewish rabbis who pronounced, with warm accents of admiration, panegyrics upon a Catholic prelate. Our fierce don Juans might well learn there to respect woman; and indifferent fathers, veneration for his majesty, the child."

A second remarkable utterance in favor of closer relations with the United States, which also attacks strongly the Pan Latin school of orators that have had the ear of Latin America in the past, is contained in a series of articles by Señor José Barcas in Causimodo, and reproduced in English in Inter America. Señor Barcas is a young Argentine who has lived in the United States and several other American countries and is now giving himself to building up an all-American friendship, with residence at Panama, with the same devotion that Sr. Manuel Ugarte has been dedicating himself to tearing it down. Here are some of his virile statements, which have been copied by periodicals all over America :

"To uphold and to propagate the idea of the superiority of the Latin-American over the Anglo-American is to foster between South Americans and the North Americans the same kind of grotesque and silly vanity as that which Gobineau would foster between the men of long cranium and the men of round cranium. Rodó *** exaggerated, like every man of letters, the gifts of the Greco-Latin race. His love for ancient Greece, which he calls with unequaled grace 'the smile of history,' and his temperament of a static intellectual, without falling into the Olympianism of our insignificant megalomaniacs, prevented him from comprehending that our century is infinitely greater than that of Pericles and the Renaissance put together. In 'Ariel' he declaims against the mercantilistic influences of the Saxon of the 
North. We-as is natural-are Ariel, the verbum of the idealists; they are Caliban, the dark genius of the instincts. We, the beautiful sons of Apollo, are the 'idealists'; they, the ugly sons of Mercury, the 'Philistines.' This is the truth if at all, only in literature. In the world of facts it is different: we are the Philistines, and the true idealists are the Americans of the North.

"The pride of chivalrous gentlemen and polished conversationalists does not sit well upon us when we need to have the children of Caliban come to wash our faces, sanify our habitations and make us clean in order that we may have better health. What else than this signifies the attitude of the Rockefeller Institute, voting roo million dollars to send technical expeditions commissioned to drain the malarial regions of South America? Rodó forgot, among other things, that our race has not yet produced an Emerson, a Poe, a Walt Whitman, an Edison, a Lincoln. He forgot that in that country of traders the only privileged beings are women and children, which does not happen with our romantic race of gentlemen and troubadours.

"If we had ideals, we should have a homogeneous civilization typically South American as the United States has a civilization typically Yankee. We should have a history, because we should be occupied in 'making' history and not in 'commenting upon it,' boasting vainly of what our grandfathers and our great-grandfathers did. If we had an idealistic sense of life we should not drive our claws and teeth into the neck of the Messiahs who bring us a new creed; we should not combat, with persecution, prison and exile, the one who professes, not the ideas of yesterday or of the day before yesterday, but the ideas of to-day, to-morrow and the day after to-morrow. Let us not confound, in Heaven's name, Philistines disguised as romantics with true idealists."

Heilo Lobo of Brazil, another splendid example of the young men who have examined their country with critical affection and have their eyes toward the future, has pointed out in a recent study, "Cousas Diplomaticas" (Affairs Diplomatic) that the relationships between Brazil and the United 
States have always been most cordial and his country has never had the least reason to feel slighted by the Northern Republic. He shows conclusively the unfairness of the arguments of Eduardo Prado.

Raffiel Urtecho of Nicaragua has pointed out a most important matter when he insists that there is no real cause for rivalry or ill-feeling between the two schools of thought under discussion. He says:

"It has been said by some that Pan Americanism consists in that sentiment of solidarity which ought to exist solely between nations of the same race, and which would be expressed by the term Pan Hispanism; but inasmuch as the latter is a sentiment, a memory, a devotion to Spain and to everything of Spanish origin, rather than anything else, it does not argue the existence of any incompatibility between the two ideas. On the contrary, Pan Hispanism, as Dr. Porras has said, will serve as a counterpoise to prevent the absorption and annihilation of the absorbent elements themselves. The two doctrines can therefore be perfectly coexistent. Nothing hinders the Hispano-American countries from preserving throughout the vicissitudes of time the distinctive characteristics that are peculiar to them: their own customs, their language, their religion, all that constitutes their particular type of civilization.

"Devotion then to these ideals in no way weakens the efficacy of the Pan American doctrine, for this devotion is a sublime abstraction, like love for one's country. It does not imply any plan, any alliance or political league, which is the basic principle of Pan Americanism.

"This doctrine is a defensive bulwark for the weak nations of Spanish America. If ever, by misfortune, in the hazards of fate, this bulwark should fall tottering to the earth, these countries would become the spoils of the European or Asiatic nations.

"Our own existence is bound up intimately with that of the great North American nation. We need from her the Irotection that her power and authority mean to America; she needs from us that we cooperate in the common defence with loyalty and good will. We constitute vulnerable points 
upon the continent whereby the North American nation can be attacked in her vital interests. All that makes for weakness or for strength in us does the same for her; and therefore the United States is anxious that we bid farewell to our disorderly political life, to the proverbial administrative jumble in which we have lived, and that we make of ourselves entities worthy of respect."

Dr. Javier Prado, Rector of the University of San Marcos at Lima, Peru, in a commencement address, praises the soundness of North American life and institutions, as follows :

"Facing reality, the United States is a nation orientated and in continuous tension toward life and action. Her feeling is lively and expansive, her intellect clear and penetrating, her character firm, energetic, and audacious. She possesses will, enthusiasm, faith, and idealism for effort and great enterprises.

"Every man is valued for his energy and activity and he finds open paths for the development of his spirit of endeavor. The true stimulus and pride of the American consists in being the child of effort, in struggling and in triumphing. Obstacle and danger attract and stimulate his energies, and the greater they are, the greater are his eagerness and satisfaction in facing and overcoming them.

"The American's activity never rests. It embraces every kind of life and occupation, passing from one to another with admirable facility, rapidity, and adaptation. His energy feels the impulse to go always onward and upward. Thus progress never stops, but advances and spreads without limitation and without end.

"In the field of labor the North American earnestly seeks wealth, but this does not constitute, as many erroneously fancy, the aim of his existence. He does not pursue it or esteem it as something to be hoarded, but as a means and agent of his activity ever in movement, and as a power creative of new enterprises. American wealth in continual circulation thus develops and multiplies incalculable energies, and its treasures never stagnate or become exhausted, but 
they are mobilized, and they increase and grow in infinite progression.

"Within this marvelous environment for human activity the most humble individual can achieve by his aptitude and energy the highest positions. The true American aristocracy is founded, not upon castes, inheritance, or privileges, but upon personal worth, upon a life of effort and success in it. American individualism is thus spontaneous, wholesome and energetic, with a deep sentiment of its liberty, and in constant and creative action. In a country that develops its energies in this way, social inequalities may not be invoked upon any just grounds, since all have free scope for their aptitudes and activity."

Over against the "Song of Hate," written by Rubén Dario against the Yankees, may be set the writings of the Peruvian poet, Chocano. He sings his songs of belief in America, opposing the pessimism of most of the writers of his time as he opposes their fear of the Yankees. He sees indeed in his "Istmo de Panamá," in which he praises the energy of the Anglo-Saxon, the joint control of America by Saxons and Latins. In his "Blasón" he says :

"I am the singer of America, aboriginal and wild, my lyre has a soul, my song an ideal. When I feel myself an Inca, I render homage to the Sun, which gives me the scepter of royal power. When I feel my Spanish blood, I evoke colonial days. My verses are like trumpets of crystal."

Of course it would be quite wrong for us to conclude that this friendlier movement only began with the World War. Since the opening of the Panama Canal particularly, and the consequent increased interest of the Unifed States in Latin America, there have been many signs of reciprocal appreciation by our southern neighbors. In I9Io Señor Roque Garrigó, Cuban deputy, condemned Iberic influence. His eloquent book, "America for the Americans," analyzes the cliverse aspects of the Spanish decadence, the illiteracy of Spain, the stationary condition of its industry, and its incertain moral life, and shows the great advantages to be found in close relations with the United States. 
The establishment of North American banks and agencies for our large manufacturing concerns in the principal cities of South America has had more influence in promoting friendly relations than would be supposed by superficial observers. It has also led to some interesting social changes. For instance, in Chile, where workmen in the past have been very badly treated, some of the North American firms have set up new industrial standards. They have increased wages and put in modern welfare work, with workmen's cottages, clubs, and the prohibition of liquor. This welfare work has had such splendid results that other firms have found it worth while to send men to the United States to study such work in order to retain their workmen.

The recent disposition of the United States to change its attitude toward the Latin American peoples from jingoism to a real sympathy and appreciation is another influence that is promoting international friendship. The wise utterances of President Wilson in his Mobile speech, and on other occasions, have gone far to assure the Latin Americans that we have no designs upon their territory. Our staying out of Mexico, when all recognized that, according to international custom, we had a right to intervene, has had a remarkable influence toward clearing us from the suspicions long held by the Latin Americans.

La Prensa of Buenos Aires, perhaps the best-known of South American dailies, commented on President Wilson's address to Congress, December 7, I9I 5, as follows :

"There has been a gradual and continuous change in the American policy toward the republics of this continent. These changes have been coincident with the visits of prominent Americans to South America, with the result that a better knowledge of the state of civilization which has been reached by South Americans has become more general. This has been the principal cause of the gradual transformation. The Monroe Doctrine is now essentially modified. It is necessary that it should no longer have the character of tutelage that it had at the time of its origin, but it must undergo an evolution toward Pan Americanism. 
The exchange of visits between university professors of North and South America during these recent years, and the large number of Latin American students who have studied in North American institutions, have made most important contributions to this development of friendship.

It is impossible to estimate the influence for closer friendship of such professors as Dr. José M. Galvez, who has sent ten Chilean students to the United States in the last three years; and Professor Ernesto Nelson of Argentina, who has a most commendable plan for enlarging our educational relationships. One would like to go into detail in this matter, telling of the contributions being made by distinguished educationalists such as Ernesto Quesada and José Ingenieros of Argentina, Olivera Lima and Helio Lobo of Brazil, Abel J. Perez and Zorella de San Martin of Uruguay, Javier Prado and Victor Andres Belaunde of Peru, Enrique Molina and José Maria Galvez of Chile, Andres Osuna of Mexico, and others, whose far-reaching service I have come to know and understand. The visits of some of our own university professors to Latin America, such as William $R$. Shepherd, Leo S. Rowe, and Edward A. Ross, and Chapman, have also done great good. Such visits are forerunners of exchange professorships, which are all too slow in being inaugurated.

The constant friendly influence of the North American missionaries through the years must certainly be set down as also far-reaching. No man that has an open mind can fail to realize that the work of such men as W. E. Browning, H. C. Tucker, IV. A. Waddell, John W. Butler, Chas. W. Dreese, David Trumbull, and many others like them, has an influence for international good will impossible to calculate. A book might easily be written on what the evangelical schools are doing in interpreting Latin and North America to each other. The Young Men's Christian Association is particularly adapted to this work of international friendship, inasmuch as it reaches many of the influential classes who are not yet willing to have relationship with a work which is directly missionary.

It would be easy to continue the quotations such as those rom Semprun and Barcos to show how Latin American 
authors during the last few years have spoken favorably concerning closer relations with the United States. In other chapters several have been cited. Let the final one here then be from the veteran Mexican writer and jurist, Señor R. de Zayas Enríquez. In a notable article published in La Nueva Democracia, concerning dangers of anti-Americanism, Dr. Enríquez opposes in the first place the ideas of García Calderón, Manuel Ugarte and others who have suggested an alliance with the Germans or the Japanese, to defend themselves from the United States. He continues: "These opinions and others of the kind are very general from Mexico to Patagonia. The United States should realize this and the Latin Americans should study with much pains how to eliminate prejudice in order that the future of our respective republics shall not be compromised and another world conflict provoked. The United States cannot afford to reject these opinions as absurdities, for in politics nothing is absurd. The Latin Americans, on their side, should reject these extreme ideas and avoid a danger, which if it seems remote, means delivering themselves into the arms of powers with which there are no natural kinships, for these are peoples with whom it is not possible for us to associate; neither Germany nor Japan are races with which we could mix.

"Germany is absorbent and exclusive. It does not wish to enter as a competitor nor as a co-laborer but as the sole owner. It does not wish to contribute to the development of our countries but to their exploitation. Concerning Japan it ought to be remembered that only a few years ago the famous Count Okuma declared frankly that South America was understood as in the sphere of influence of Japan. We Latin Americans ought to realize that there are no gratuitous alliances, for all result badly for the weak one,-all without exception. Japanese intervention in our destiny would signify the death of the nationality of the people that admitted it, and, therefore, it is inexcusable to pretend that it would serve to defend our autonomy.

"I do not believe that the United States will carry its imperialism to the point of desperation, causing the Latin American spirit to commit suicide. Neither do I wish to 
believe the Latin Americans will carry their anti-Americanism to the point where they will submit voluntarily to Pan Germanism or Panjapanism in spite of what some authors say.

"Let us ask, in case the United States should be invaded by a foreign power, a hypothesis which is not inadmissible, what attitude would the Hispanic American nations take? It is possible that some thinkers listening to the voice of resentment, because of the acts of the Yankees so often mentioned, would advise our entering on the side of the aggressors, forgetting that international politics does not proceed from sentiments nor from resentments, very rarely from abstract principles, but almost always from conveniences, which because it is a matter of dealing with foreigners is generally a matter that affects the vital interests of our own country, that causes us to decide.

"The instinct of conservation would oblige us, in such a remote case, to give our moral aid, if we could not offer anything more effective, to the north American union, converting the original Monroe Doctrine into a continental principle, as an eloquent protest against all foreign invasion.

"For I am persuaded, in spite of what I have said here and in other places, concerning the imperialism of the United States, all of the republics of this continent have a vital interest in the existence of the United States as a prosperous and strong nation. Our life is united to hers in an inexplicable nature.

"The moment that she should disappear or her forces be divided or her moral influence weakened, the HispanicAmerican powers would be at the mercy of the great European nations and Japan. On what powers of men and money would we be able to count to resist their advances? Brazil, Argentina and Chile, that are the three most powerful countries, supposing that they should unite together, would with great difficulty accomplish an almost impossible task. The others, Mexico included, which is the largest, would be able to carry out great acts of heroism which finally would result in failure.

"We should realize that Germany, in spite of the situation in which she has been left by the war, in a few years will be 
in a position to struggle with great advantage against any of our Latin American nations, but she will certainly not attempt it while the United States shows itself formidable.

"It is not the much debäted Monroe Doctrine that saves us, but it is the force that is behind this Doctrine. It is not the altruistic love of the United States that favors us, but the national interests of the Yankees that no European power shall establish itself nor become a preponderant influence on this continent; and if this does not behoove the United States, no less does it behoove the Latin American nations, for we might easily lose our autonomy and become colonies of European countries.

"Besides these political considerations there are also economic considerations which are of great importance. Since, therefore, there does not only exist reciprocity of economic interests but political interests among all the peoples of this continent, why not come to a definite understanding, in order that there may disappear all that is disagreeable, undesirable and dangerous in our relations and foment and develop all that is good and that we recognize as necessary? Let us establish at once Pan Hispanism as a secure basis for Continentalism which will be the perpetual guarantee for all the peoples of the New World.

"If I say Continentalism instead of Pan Americanism it is because the last term is somewhat discredited among the Latin American people, who take it as a concept that involves the hegemony of the United States over the rest of the continent. Let the United States and Latin America persuade themselves that America cannot occupy its proper place in the balance of world power until it is united politically. With the establishment of continentalism, America will occupy its proper place among the nations, maintaining the equilibrium of the world, a work for which it has been predestined."

To a certain extent the two schools of thought, into which Southern America is divided,-Pan Latinism and Pan Americanism,-revolve around mere sentiment and misunderstanding. Tancredo Pinochet, a Chilean who has lived in several countries of North and South America, has recently 
written a most excellent book called "The Gulf of Misunderstanding," which shows how the Latin American for various reasons has completely misunderstood the North American. Due to many of the influences mentioned in the early part of this chapter Señor Pinochet shows that the North American has been misjudged in regard to such important subjects as materialism, imperialism, treatment of the negroes, woman suffrage, marriage and divorce, religion and education.

In so far as the prejudice of Latin Americans against the United States is due to misunderstandings and enemy propaganda, and the attacks of the Pan Latinists are unjust, we should counteract this movement with a careful campaign for spreading the truth-a serious task which challenges the best and noblest talent of the nation. In so far as are just these claims that we are rude, uncultured, unsympathetic, materialistic, lacking in appreciation of others good qualities, interested only in their mines, their oil, their wheat and their territory, we should strive with all our power to correct them. Happily there are to-day many organizations in both the continents that are working unselfishly and unceasingly on both of these problems.

North Americans should always make it clear that they do not object to but rather approve the Latin family standing together, just as they believe that it is a good thing for English-speaking peoples to stand together, so long as it is not for the purpose of resisting other racial groups. Indeed, all those who have come to appreciate the beauties and wonders of Hispanic culture would be glad to see this culture conserved by its inheritors. A close relationship between the mother countries of Spain and Portugal with their children in America, not antagonistic to others, should rejoice the world. The same should be the case of unity among the various Latin peoples of America. President Brum of Uruguay has recently stated that all Latin America should form a federation among themselves and enter unitedly with the United States into an inter-American agreement. Thus he thought Latin America's prestige might be increased as well as her contribution to Pan Americanism. The North American colony in Montevideo immediately approved this sug- 
gestion. When Panama recently appealed to Argentina, denying the validity of the decision of the United States concerning territory under dispute with Costa Rica, Secretary of State Hughes willingly sent all documents in the case to the Argentine authorities. Unity of family groups among nations can do only good so long as they are based on justice and good will, not for themselves alone but for the rest of the world.

\section{Sources of Further Information on Pan Americanism vs. Pan Latinism}

Altamira, Rafael: España en América.

Araquistain, Luís: El Peligro Yanquí.

Berenguer, Fernando: El Hispano-Americanismo.

Blanco-Fombona: Grandes Escritores de América.

Bulnes, Francisco: Las Grandes Mentiras de Nuestra Historia. CaLDERón, F. García : La Creación de un Continente, Wilsonismo. ENRíquez R. DE Zayas: "La Nueva Democracia," August, 1920. GarRigo, Rogue E.: América para los Americanos.

Gaxiola, José: La Frontera de la Raza.

Giberga, Eliseo: El Pan Americanismo y el Pan Hispanismo.

-Godoy, F. García: Literatura Americana de Nuestros Días.

LoBo, Hel1o: Causas Diplomáticas.

Manero, Antonio: México y la Solidaridad Americana.

Ortiz, Fernando: La Reconquista de la América.

Pinochet, TANCREDo: The Gulf of Misunderstanding.

Posada, Adolfo: En América, una Campaña.

Pereyra, Carlos: El Crimen de Woodrow Wilson.

Prado, Eduardo: A Ilusao Americano.

Prada, Javier: La Nueva Epoca y los Destinos Históricos de los Estados Unidos.

Rodó, JosÉ ENRIQUE: Ariel.

UgARTE, M.: El Porvenir de la América Latina.

VARGAS VILA, J. M.: Ante los Bárbaros.

World Peace Foundation: The New Pan Americanism, Part II. Files of Inter-America and La Reforma Social. 


\section{Chapter X}

\section{NEXT STEPS IN INTER-AMERICAN FRIENDSHIP}

Let us, in conclusion, glance at the past and then look for a moment at the possible future of inter-American relations. The cool monopolizing of the name "American" by the people of the United States alone shows how difficult it is for us to include in our consciousness the other twenty American republics. Many even of the great North American advocates of world brotherhood pass by Hispanic America as though it did not exist. There may have been excuses for this in the past, but certainly there is none today and the continuance of such an attitude involves a tremendous peril.

The rest of the world is watching these growing young nations with the deepest interest, recognizing the far-reaching developments that already foretell the important place these countries are to occupy in future world life. On the other hand, the rest of the world is coming to count North America's attitude toward these nearest neighbors as the best interpretation of our whole national life. We cannot render the service we should in bringing about world brotherhood until we have set our own house in order. It ought to be of profound concern to every North American that one of the best known poems in Latin America, a favorite recitation even for school children, is one by the celebrated Rubén Dario, the following being a partial translation of this awful indictment of North American Materialism, dedicated to President Roosevelt:

"Tis only with the Bible and Walt Whitman's verse, That you the mighty hunter are reached by other men. You're primitive and modern, you're simple and complex, A veritable Nimrod, with aught of Washington. You are the United States. 
You are the future foe

Of free America that keeps its Indian blood,

That prays to Jesus Christ, and speaks in Spanish still.

You are a fine example of a strong and haughty race,

The United States are rich; they're powerful and great;

They join the cult of Mammon to that of Hercules,

And when they stir or roar the very Andes shake ***

And though you count on all, one thing is lacking-God!"

Version of E. C. Hills.

Latin America did not always think of us in that way. In the early days of her struggle into national life she admired us and looked forward to an American. Union. The great Bolívar called the Panama Congress in 1826 to form an American League of Nations, and said:

"When more favorable circumstances afford us more frequent communications and closer relations, we shall hasten, with the liveliest interest, to set on foot, on our part, the American covenant, which by forming one political body of all our republics, shall present America to the world with an aspect of majesty and greatness without parallel among the ancient nations. America, thus united, will be able to call herself the queen of nations, the mother of republics."

That wonderful spirit of the South was matched by an equally great champion of American Unity in the North, the indomitable Henry Clay, who, in urging Congress to recognize the struggle of the Spanish colonies, said:

"In the establishment of the independence of Spanish America the United States has the deepest interest. I have no hesitation in asserting my firm belief that there is no question in the foreign policy of this country which has ever arisen or can arise in the decision of which we can have so much at stake. This interest affects our politics, our commerce, our navigation. These Spanish-American governments, once independent, will be animated by an American feeling and guided by an American policy. * * * We are their great example. Of us they constantly speak as of brothers, having a similar origin. They adopt our principles, copy our institutions and often employ the ve:y language and sentiments of our revolutionary papers." 
Unfortunately these words of Clay ceased to be true after the Mexican War, which clearly marked the time when to a large extent they ceased to "constantly speak of us as brothers." A decade later the expeditions of the filibuster Walker to Central America drove a number of the southern republics into an alliance against the "Manifest Destiny" program of their northern neighbor. A series of incidents in our relations with Chile, including our favoring more consideration for Peru, when she was conquered by Chile, our compelling an apology for the killing of the sailors of the "Baltimore" and the brusque forcing of payment of the Alsop Claim, set that country and her very strong influence in Ecuador and Colombia against us. The Spanish American War, instead of appealing to Latin America as a demonstration of our idealism, seemed to her the act of a bully attacking a weak, exhausted neighbor for commercial advantages, and gave rise to an influential school of advocates of Pan Hispanism. The Platt Amendment and the occupation of Porto Rico and the Philippines were to them clear proof of this. The protection of Panama in its revolution against Colombia and the securing of the Canal Zone without recompense to Colombia; the interference in the internal affairs of Central America, with the permanent establishment of a guard of marines in Nicaragua and the violation of rights of other Central American nations by the Bryan-Chamorro treaty with Nicaragua; the Lodge Amendment, prohibiting all Latin American nations from exercising sovereignty in disposing of their national domain; the forcible establishment of a protectorate over Haiti; the establishment of a military government in Santo Domingo; the capture of Vera Cruz and the Pershing Expedition into Mexico-these are the outstanding explanations for the prejudice as expressed by the poet Dario and by many others, as pointed out in the course of this discussion.

If one were addressing the Hispanic Americans, he would point out the vitally erroneous interpretation they put on many of these events, and they would set over against hem our mediation in the war between Spain and her former colonies in 1870 ; our action forcing the withdrawal of French troops from Mexico; our protection of Venezuela 
from European aggression; the freeing of Cuba ; our contribution to order, education and civilization in the Caribbean, and many other services rendered to our less powerful neighbors. Just now, however, we are talking to ourselves; not for defense or for tickling our vanity, but for selfexamination and an understanding of how we appear to our neighbors. This is no pleasant task, but since those of us who live among our southern neighbors must continually hear such criticism, it is probably not more than just that those at home should face up to it once in a while.

In 19I4, after living in this atmosphere of suspicion in Mexico for ten years, I visited practically all the other Latin American countries and found the same suspicion as in Mexico. I came to the conclusion that this distrust was the greatest hindrance in the development of North American spiritual, commercial and intellectual influence in the South and that there was no more important service than that of breaking down this "middle wall of partition."

On my next visit to South America, in I9I7, I found a most encouraging change in the situation. Our entrance into the World War, with its unselfish implications, had convinced our southern neighbors that we were really idealistic. "American Solidarity" was the expression most often heard. Even the university students, who had been the most violent anti-Yankees, now showed themselves especially cordial. As a result of meetings with the students in Chile, where Yankeephobia had been most noticeable, they later sent a representative to this country. It was my pleasant duty to help outline his itinerary for a visit to the North American colleges to consult with students as to what the students of the two countries might do toward bringing their peoples nearer together. The growing cordiality between the two nations is notable. Chile recently placed a loan in the United States. This new drawing together is typical of the whole of America. It is the outstanding happening in Pan American relations during the last twenty years.

Even Rubén Darío changes his attitude of indignation toward the Colossus and more recently has sung: 
"No, let not hatred discharge its arron;

Bear to the altar of peace honey and roses.

Peace to stupendous America! Peace, in the name of God!

And as hers is the center of a new culture

That spreads its principles from north to south,

Let us build a new union that unfurls a new device:

The Star Spangled Banner with its red, white and blue."

These closer relationships have been developing also in the commercial world. When Europe could no longer furnish capital and manufactured goods Latin America was compelled to come to us. So the foreign commerce between the United States and her southern neighbors has grown from 700 millions in 1913 to practically 3 billions in 1920. If we did as much business with the rest of the world as we did with Latin America, proportionately, our trade would total 45 billions instead of 12 billions.

In spiritual matters our southern neighbors have also come to be more open to North American ideas. In former time the educated classes had largely turned against the Church. Since she was opposed to education, to democracy, to progress and to science, the educated people lost interest in all religion. Evolution and the economic theory of life came to be all-sufficient. But when they saw that the most scientific of nations was the one that had led the world astray they began to realize that they must have a spiritual basis for their own national life or fail to attain true greatness. The change from the old attitude to the new is well illustrated by the university students. In the old days they very often organized a manifiesto and paraded the streets in protest against some abuse by the Church or the State. But a few months ago the students of Córdova organized a demonstration and paraded the streets in a new spirit. No longer did their banners say "Down with the Priests" or "Death to the Foreigners" or any other negative demand. Their banners bore only the significant words, "Luz, más I.uz" (Light, more Light!). This to-day is the universal cry of the younger element in every part of Latin America. Chey realize that the world is facing a new day. And they want light on its meaning.

And to whom do they look to furnish this light? A dis- 
tinguished South American educator said recently: "All my life I have looked to France for my spiritual inspiration. But to-day I believe that unless North America shall save the world it will not be saved."

While it is true that the world reaction toward selfishness following the war, which has been seen so clearly in the United States, has abated somewhat this enthusiasm for North America, it is still true that never in American history has there been such a favorable setting for the great Pan American drama. The supplanting of suspicion by a desire for friendship, the multiplication of means of communication, the interdependence of economic life, a new open-mindedness concerning spiritual matters and an everincreasing mutual appreciation have brought us to this truly wonderful opportunity.

But if all are to play their parts with the enthusiasm required to make this great American drama a success, there must be sympathy and mutual concern on the part of all. On the part of the older, stronger actor there must be a double portion of respect and helpfulness for the other players. And certainly the star of the play, because of his riches, power and reputation, must not seek to use the other characters simply to add to the glory of the central figure.

Let us consider some of the practical steps that ought to be taken by the United States for the development of a real Pan Americanism.

\section{EARLY IDEALISM}

We ought to maintain the idealism which drew Latin America to us during the World War. Confidence in this idealism has been strained in Hispanic American minds by the reaction that has set in here since the armistice. There is a growing fear that we will use our financial and military power to oppress weaker peoples. The talk of huge navies and high tariffs has a sad reaction in South America. There is a feeling that we have suddenly drawn within ourselves instead of using our great resources in guiding the reconstruction of the world. Latin America does not care particularly about the form that a league of nations may take, 
but she is tremendously in favor of a league that will protect the small peoples. An ex-president of Brazil was recently asked whether or not his country, having followed the United States into the war, would resign from the League of Nations if the United States did not enter. He replied that Brazil would then feel it doubly her duty to remain in the League, for she would have to represent the idealism of both nations. Another prominent South American declared that if it became necessary for South America to choose between the Monroe Doctrine and the League of $\mathrm{Na}$ tions, it would choose the League.

We ought to study how to eliminate all those objectionable features in our dealings with our southern friends which have come to be designated as the Big Stick, Dollar Diplomacy, and Shirt-sleeve Diplomacy.

Reference has already been made to the visit of Admiral Caperton's warships to Brazil, Uruguay and Argentina during the war as one of the most important events in the development of closer international relations between North and South America. It was natural that some Latin Americans should see in the fleet's visit a threat of force, as they do in many of North America's gestures of friendship. At that time this was especially true in Argentina, where even after the fleet's arrival some of the prominent men of the country retained the idea that the visit had been forced upon them. It was most interesting, however, to see the way in which a direct acquaintance with our admiral and his men changed this attitude. I recall particularly a conversation that $I$ had with a prominent professor in the University of Buenos Aires. Before the fleet's visit we had talked over carefully various problems connected with the enlargement of friendship between our two countries. $\mathrm{He}$ had expressed his belief that Argentina should cultivate closer relations with the United States than with any other country. While I was visiting Montevideo, however, he made an address at a public meeting in one of the large theaters of Buenos Aires protesting against the Government's inviting the North American fleet. On my return to the city we met at his club on the Avenida de Mayo. As the Latins do, we talked around and about many questions until 
I finally said to him: "I am soon returning to the United States and shall have opportunity of speaking to my people concerning these problems of friendship about which we have been talking. I should like to know your final recommendations as to how these may be better cultivated."

Quick as a flash, he turned to me with an upraised hand and said: "Don't force us! This matter of the visit of your fleet doesn't set well with us. It seems that you are forcing us to take a position that we are not yet ready to take. I believe, as your country believed for a long time, that the best thing for Argentina is neutrality. If your protests of friendship and of allowing us to shape our own policies are sincere, then you have no right to force us into a position which really means a declaration of hostilities."

I replied: "I appreciate what you say and cannot entirely answer it, for I do not know the secrets of our State Department. I am sure, however, that it has reasons for what it has done in connection with the fleet's visit to Buenos Aires, if it has suggested the visit, as you claim it has. But I do know the hearts of our people. I believe that I understand the purposes of President Wilson and his Cabinet, that they are thoroughly in accord with the public declarations made by the President concerning our desire for friendship with Latin America and for allowing each nation to direct its own policies. At a time like this is it not necessary for us to trust one another? Some day you and I will know what only our governments now know. Then I am sure that there will be a satisfactory explanation." Spontaneously he extended his hand and exclaimed, "You are right. We will trust one another."

This incident may be said to be typical both of the fears of the intelligent and cultured South Americans and of their real desire to cultivate friendship with us. A careful explanation of our own purposes and a due regard for our neighbors will smooth the way every time toward real friendship.

Shirt-sleeve diplomacy is well illustrated by a recent incident in Panama in connection with the acquiring of Taboga Island by the United States. The United States was desirous of placing fortifications on this island in order to 
safeguard the Panama Canal and quite suddenly notified Panama to release this most prized possession, which her nabobs use as a summer resort. The public in the United States would probably never have known anything about the matter had it not been that General Pershing's recent visit to Panama gave the Panamanians an opportunity to stage a demonstration against the United States' seizure of the island. Just about that time also, Major Lowther in the British House of Commons, in order to plague his political enemies, placed before the Under Secretary for Foreign Affairs of his government the question as to whether the taking of this island by the United States might be referred to the League of Nations as an infringement of the rights of small nations.

Negotiations for acquiring the island were properly initiated by the State Department of the United States with the Panamanian Minister at Washington. While this was pending in Washington it seems that an under official of the American government of the Canal Zone appeared, with more haste than ceremony, before the Alcalde of Taboga and announced the impending seizure, declaring he had been sent by the American authorities to make preliminary arrangements for removing the inhabitants. The Alcalde refused to recognize the American agent. Our War Department contended that the agent went to Taboga with the consent of the government of Panama, but the latter denied the accuracy of that contention. The Panama Government had understood from advices of the Secretary of State that the United States Government would do nothing precipitately and that no action would be taken until the negotiations at Washington had been satisfactorily concluded.

The Panamanian Minister then called the attention of the State Department to the incident and described what an unfortunate impression it had made. His note presented three requests from the Government of Panama: That the amount of land taken for fortifications be reduced to a minimum, that there be no immediate expropriation of private property beyond what was absolutely necessary, and that the United States leave to the inhabitants of the island what they need and cherish most-their water supply and 
their graveyards. The incident aroused such intense feeling in Panama that the populace staged a very ugly demonstration against General Pershing, their only opportunity for bringing it to the attention of the outside world. Whatever may be the just settlement of this matter, certainly a proper diplomatic handling of the case would have proved more satisfactory to both sides than would such a process as that just described.

The American officer may not actually have gone in his shirt-sleeves to demand the island of the Alcalde, but he gave the impression of being rude and inconsiderate of the dignity of the Government of Panama and its officials. His dignidad may be the last thing that a North American considers, but it is the first that a Latin regards. He would rather starve than sacrifice his dignidad, individual or national. If we could only remember this in dealing with him we should get many things done, even disagreeable ones, without causing rancor and resentment. Not long ago the writer was discussing with a Latin American the question of how we might legitimately help some of the Caribbean countries to maintain peace and develop democracy without incurring their ill-will. "Todo está en 'la forma," he replied earnestly. And indeed almost everything in Latin America does often seem to depend on the form. Certainly anything that is just can be carried out if we are considerate of our neighbors' feelings. It would not hurt even to cater a bit to his pride and prejudice, where principle is not involved. The North American is often too proud of this "brutal frankness" and his presentation of the "naked truth." We shall get along much better with South America when we dress up the truth in garments of sympathetic consideration and forget the "shirt-sleeves" method of presenting it.

A few months ago when the Tacna-Arica question between Chile, Bolivia and Peru again became acute, our State Department sent a note to the countries concerned which caused much unfavorable comment. La Prensa, of Buenos Aires, referring to the brusk admonitions of the United States Government, characterized them as if from a tutor to a disorderly pupil, and asked: "What is the cause of that arrogant style of diplomacy adopted by the White House?" 
El Mercurio, of Chile, said: "The American Government should now open well its eyes and take note of the mentality of these countries, of their present state, of their degree of progress and of their self-respect. It must not be forgotten that one of the causes of Germany's ruin was the lack of comprehension of other peoples' psychology, under which German statesmen have always labored. We hope, for the sake of mutual expediency, that the Americans will show themselves to be more intelligent." Even the American Chamber of Commerce of Valparaiso thought it necessary to protest against the tone of the note.

The bluster, bravado and threatening of the United States Senate's Committee Investigating Mexican Affairs and their unreasonable demands on Mexico is the best kind of an illustration of how not to do things if we wish to have any of the persuasive elements in our diplomacy. The public announcement that this government wishes to have appointed a joint commission to settle questions between the two governments, and that Mexico must promise beforehand to do certain things, offers the Latin American cartoonist another opportunity of picturing Uncle Sam, with a big stick, saying to little Mexico, "Come now, quick! Let's make an agreement! Sign here!" Consideration and persuasion will get a good deal more from Mexico and will make the rest of the world think a great deal better of us. The best known cartoon in Latin America arose out of our "Dollar Diplomacy" used in the collection of the Alsop Claim from Chile. This cartoon represents the United States as a big, fine gentleman in Prince Albert coat, high hat, gold-headed cane, and diamond stickpin and all the rest, saying to a poor little chap: "My boy, get to thyself riches-honestly, if thou canst. But by all means, get to thyself riches."

When one goes over the record of our dealings with Latin America and finds that many times as much and more could have been accomplished in a given matter by the proper form and proper consideration of Latin sensitiveness than have been gained by our rough methods, which leave a sting and resentment, he appreciates the great place that sympathy has in the development of Pan Americanism. It would of course be neither fair nor true to say that Latin America is 
so superficial as to care for nothing but form. The content is of importance. And the content of Pan Americanism must not include North American imperialism, if it is to be accepted by the South.

Nothing would do more toward forwarding American Unity than an authoritative declaration by the combined treaty-making powers of the United States Government embracing the principles proposed by President Wilson for a Pan American agreement. These were: The United States and all other nations of this hemisphere mutually agree to guarantee the territorial integrity of the countries of this hemisphere; all the nations agree to maintain the republican form of government; all bind themselves to submit to settlement by diplomacy, arbitration, or investigating commissions as provided for by the several treaties already ratified, disputes of all kinds, including boundary troubles, but not controversies affecting the independence of each; general agreement whereby exportation of arms to any but the legally constituted governments of this hemisphere will be prohibited; neutrality laws adopted which will make it impossible for filibustering expeditions to threaten or carry on revolutions in neighboring republics.

These agreements would naturally lead to an extension of the joint consideration of American problems by various American nations, as happened in the mediation between the United States and Mexico. The more the United States can call on the stronger countries of Latin America to help her in bringing law and order to the unstable countries, the greater will be the appreciation of the difficulty of the problem of the United States in relationships with the disturbed Caribbean countries. Such joint action would both remove the suspicion of land-grabbing and broaden the Monroe Doctrine to where the whole Continent would feel responsible for its maintenance, thus eliminating the one objection to the doctrine that it is entirely unilateral.

\section{SOME TROUBLESOME PROBLEMS}

In order that the Pan American drama may proceed it is necessary to clear away two imperative questions. These 
are: Friendly reciprocity with Mexico, and just and satisfactory relationships with the Caribbean countries.

The one thing that would wipe out all the advantages of the present wonderful opportunity for Inter-American friendship is the very thing that started all of Latin America's suspicion of us in the first place-war with Mexico. We ought clearly to recognize that Mexico is a part of that great Latin family and her sisters have a deep sympathy with her. They do not hold any false ideas as to her perfection or fail to recognize the justice of the claims of the United States for just treatment of her citizens and her interests. Their impartial work in the A B C mediation between Mexico and the United States in I9I 3 proved that. But they do believe that the greatest nation in the world, that holds two-thirds of the wealth of the world, that claims to have gone further than any other nation in the development of democracy and to have fought a war for the weak peoples of the world, ought to be able to find some other way of getting along with a next-door neighbor, like poor little, weak, revolution-tossed, exhausted, starving Mexico, than by shooting it into submission to our imperial will. And rightly or wrongly, no pious phrasing of our benevolent purposes, and our interest in Mexico's welfare by our national congress, as we send our armies to Mexico, would ever convince Latin America that armed intervention was not for the purpose of making more sure our economic exploitation of that unhappy land.

Intervention is short-sighted even as a commercial policy, for it would cause us to lose the trade of Latin America. But many commercially-minded people cannot see this. In a recent book entitled "Is Mexico Worth Saving?", the advice of the author is to deal with her only by ultimata. That would undoubtedly save her-from certain sins, at leastfor Mexico's greatest sins are oil, silver, gold and copper. As long as Mexico has these sins certain interested evangelists will be deeply concerned for her salvation. So it is necessary for the best elements in this country to stand eternally against armed intervention.

The United States of America is too big a nation to admit that the only way to settle its difficulties with a small, weak 
nation is by a war. Mexico has only one-seventh the population of the United States and has not one-hundredth part of our national wealth at the present time. We have come out of the World War as the most powerful government, financially, in the world. We have also developed an idealism which has said to the world that we will go to any lengths to help weaker nations that are struggling for a democratic life. There is no power that human beings can wield that has not been given into our hands. Christian civilization is certainly an absolute failure if the United States, with all of its power, cannot find a way of settling our difficulties with Mexico without war, and we should not allow ourselves to believe that intervention means anything but war.

As for the destruction of property, rather than go to war, Admiral Chadwick said several years ago: "Far better if only from a financial point of view, would it be for us to buy up every foreign interest in Mexico."

One of the ways to settle the Mexican question is to do away with the propaganda which has poisoned the minds of the American people against the Mexicans by continually keeping before the public not only stories of atrocities, but the weaknesses of Mexican leaders, so as to undermine entirely the faith of the American people in the Mexicans and their rulers. We allowed this propaganda to assume such proportions that the Mexican Minister in Washington, according to his own personal testimony, has often found these misrepresentations so unbearable that he would go into an inner room and shut himself off from all life for days at a time. All Mexicans and friends of Mexico in this country have felt the embarrassment and the shame of these conditions. We have complained that the governors of Mexico and the Mexican people have prejudice against the United States, and we have allowed the flames of this prejudice to be fanned by propaganda agencies that have had nothing but selfish motives behind their work. The United States is big enough and great enough and ought to be Christian enough to change entirely this whole situation and help Mexico to restore her homes, to educate her children and to take her rightful place in the Pan American family. 
As to the Caribbean countries, a just and clearly defined policy is imperative. For the last several years the United States has had a force of $I, 500$ marines in Haiti, a like number in Santo Domingo and a hundred in Nicaragua. In Santo Domingo we took over the government completely five years ago and since then the marines have been the only government. Whether or not the seizing of that government was justified, the American people will not be content to permanently hold another nation's sovereignty and permanently rule that country by martial law. The relations with these small Caribbean countries, that have been cursed with revolutions for a hundred years, is a serious problem. But it is a problem not for some minor official at Washington to solve, but one for the American people to study and about which they should reach just and wise conclusions.

\section{IMPROVED DIPLOMACY}

There is imperative need of improvement in our diplomatic organization and personnel. The importance of having the best type of men to represent us in Latin America, where there are so many prejudices to overcome and so many false impressions to be eliminated, cannot be overemphasized. The Southerners are individualists and hero worshipers. They see everything through the kind of men that present matters to them. Our diplomatic representatives are to them the very embodiment of the United States. We have had and have to-day some very fine men in the diplomatic and consular service, men who have by their own character and culture lifted high the whole conception of North America. It would be difficult to estimate the wide influence for good of such men as Ambassadors Morgan of Brazil, and Fletcher, of Chile. Unfortunately we have had many of the other kind. Some of them are only provincial and find it impossible to see a question from any but their own narrow viewpoint. Others have been tipplers, immoral and dishonest. Very recently in one of the Central American countries the Minister representing the United States, after years of offending, was finally removed from office because of drunkenness. His successor, although an old 
man, fell in love with a very young native girl and his conduct with her at motion picture theaters was so disgusting that he was several times hissed by the other patrons. He likewise was finally removed from office. During the World War our Minister to one of the South American countries got mixed up in some questionable investments, so that at his death a scandal was created by a claim that this procedure was only a hoax for him to get out of the country and a demand made that the casket be exhumed for investigation. Another Minister is reported to think so highly of the Papal Nuncio and is so deferential to the Roman prelate, even renouncing first place to him, that the Liberal element of the country are very much perturbed by his actions.

It is not an uncommon experience to find the work of subsecretaries, clerks and even consuls carried on by those who with difficulty speak the English language. Many incidents, amusing afterward, but humiliating to the patriotic North American at the time, take place, like the one related to the writer in Rio de Janeiro. It seemed that on a national holiday the American colony had gathered together for a celebration. The Ambassador was away so that it fell to an under official to make the address. It was a hot day and since the gentleman was fleshy and not over careful in personal appearance he chose to appear in negligée with no vest. In his struggles with the English language, as he talked of the great unity of spirit in the United States, he said: "Gentlemen, after de Civil Var in our cundry, ve were all united. Dere was no nord, no soud, no east and no vest," accompanying the last words with an impressive gesture toward his breast. If some have a struggle with the language of the country they represent, much more numerous are those who struggle heroically but hopelessly with the resonant Spanish or Portuguese. We need real representatives of the United States in our diplomatic and consular posts, those who speak the language and think the thoughts of the people among whom they live and typify in their own personal lives all that is best in morality, sympathy, culture and idealism in the life of their own country. It is very evident that in order to get such men adequate salaries and suitable residences should be provided. 
But it is not only in the field that our diplomatic organization needs improvement. It needs it at Washington also. With certain notable exceptions, the Latin American Section of the State Department has been officered by men who lack the qualifications, training and prestige for such an important position, men who are inferior in culture and in knowledge of international affairs to the diplomats from the various southern countries with whom they come into contact.

With the present organization of the State Department it too often happens that irresponsible clerks are left to decide questions which, however trivial they may appear to be at Washington, have a far-reaching effect in Latin America. Then, if the Department of State is to really represent the people of the United States, there must be some way whereby the people can more clearly follow what the Department is doing and express to it their approval or disapproval. Most of the governments of the world are compelled to publish to the world the activities of their Foreign Relations Department. All of the Latin American countries publish Memorias of the Department of Foreign Relations, in which is given minute account of all relations with other countries. Great Britain and other European nations have a way of interpolating their Minister of Foreign and Colonial Affairs at any time questions arise concerning these matters. The United States is probably the only democratic government in the world where the people have no way of following our dealings with other nations. The Department of State and the Navy may control the government of a little Caribbean country for years and this be the talk of the rest of America and Europe, without the people of the United States knowing about it, unless political rivalries shall force its discussion or bring about a congressional investigation. The activities of the Department of State and of the Navy, as they refer to the smaller neighboring countries, where it is so easy for a great, powerful nation to assume a dictatorial policy, should be open and subject to public judgment at all times. The reforming of our Department of Foreign Relations to insure open diplomacy is one of the greatest needs of our political organization, if what we actually do in our relations 
with the small nations under our shadow is to be representative of the nation itself.

\section{BETTER ACQUAINTANCE WITH LATIN AMERICANS}

We have need of a more adequate appreciation of the Latin American people. We must realize that these peoples are worthy of our friendship. The old attitude of depreciation must be done away with. A few months ago some American tourists, business men who had been the guests of the Mexican Government on a long visit through the Republic, from whom they had received every courtesy, were returning to the border. The train reached New Laredo, on the Mexican side, about 3.30 in the morning. These gentlemen woke up and began talking, waking up everybody else in the car. Among the things the cultured Mexicans who spoke as good English as these Americans, heard was this: "There are two things in this world that I can't understand why the Lord ever made-mosquitoes and Mexicans."

Some time ago a university professor asked his Congressman to suggest to one of the government officials that he would like an appointment as representative in one of the Pan American conferences. The government representative said to the Congressman: "Why in the world does that professor want an appointment of that kind? Why should he want to get mixed up with those Latin Americans? I can't understand why anyone would care to waste their time with them." It is a well-known fact in Protestant missionary circles of the United States that the general impression has been in the past that any kind of a person would do to send as a missionary to Latin America. People who have not had the intellectual and spiritual qualifications to be sent to the Orient have at times been sent to Mexico and South America with the thought that anything was good enough for those fields.

A South American Ambassador in Washington said not long ago, complaining of the critical spirit of Americans visiting his country: "You will not find everything there just as you have it in the States, and you must not expect more than we have for ourselves. We are very glad to share 
what we have with anyone who comes to us in good faith, but you should not be too critical of what we have to offer. Our countries are new countries, and we welcome your interest in their development, but we don't like to be told that we are backward and slow. If you don't like our hospitality you should stay at home." That is a rather general complaint against North Americans who visit South America for the first time. The traveler usually knows very little Spanish, and he is apt to be annoyed because all the nations do not speak his language. If he is very provincial in his point of view he is likely to conclude that everything is done wrongly, because it is not done in the way he is used to at home, and often loudly complains against the country and the people. Some North Americans who have resided many years in South America see none of the good traits of the people, none of the wonderful public and private charities conducted by them, nothing of the beautiful spirit of refinement and culture that captivates the open-minded. One finds at times North Americans in the cities who spend their free time maligning the good people of that city, and putting wrong impressions into the heads of tourists who come to them for an appreciation of the country.

Unfortunately this attitude has been of long standing and assumed by some of our most prominent men. In a confidential letter from the United States representative to Central America in $1850, \mathrm{Mr}$. Squier said: "You cannot imagine my astonishment on hearing Mr. Webster speak not only slightingly but contemptuously of all that had been done in Central America. He said he could not discover why we should trouble ourselves about 'these insignificant countries, or go through the farce of treating with them at all.' I urged the vast resources of the country, the importance of the present and prospective trade with California and Oregon, in short, touched upon the various points with which you are familiar. To all of this there was but one reply: that when this importance became manifest and stable governments were established, it would be time enough to pay attention to them."

These few incidents show the change of attitude that must come in this country if we are to have a real friendship 
with Latin America. We must realize that in Latin America there is a cultured class equal to any in the world. We must realize that they have produced some of history's greatest men. Victor Hugo once wrote to Juarez, the Mexican president: "America has produced two great men, Abraham Lincoln and thee." This was no mere compliment, for anyone who has studied the life of Juarez will appreciate the reason for coupling him with Lincoln. Our own Secretary of State, Seward, after he had met Juarez, said that he had never seen a greater man. When some of his friends reminded him that he had seen many great men and should be careful in making such a statement, he reaffirmed it.

In brilliancy itself the great Bolivar exceeded our own Washington. In devotion to liberty San Martin, the great liberator, was his equal. There is no finer exa nple of unselfishness in all the world than San Martin, ifter having become the victor in Argentina, Chile and Peru, quietly renouncing all his titles and honors and retiring to Europe to avoid difficulties which his presence might have caused. The following from his farewell address shows something of the spirit of the man:

"I have witnessed the declaration of the independence of the states of Chile and Peru. I hold in my hand the standard which Pizarro used to enslave the empire of the Incas. My promises to the countries for which I fought are fulfilled: to secure their independence and leave them to select their own governments. The presence of a fortunate soldier, however disinterested he may be, is dangerous to newly established states. Then, too, I am weary of hearing people say that I wish to make myself a monarch. Nevertheless I shall always be ready to make the last sacrifice for the liberty of this country, but only in the capacity of a private citizen. With regard to my public conduct, my compatriots, as in most affairs, will be divided in opinion. Their children will give a just verdict."

\section{NEW USES OF THE TROPICS}

Probably one of the greatest reasons for the average man's depreciation of Latin America is the fallacy pretty 
universally accepted by Anglo-Saxons that the great section of the earth which we know as "the tropics" is forever condemned on account of climatic conditions, as a field for great and progressive enterprises. Evidences of decadence and lack of enterprise are met by modern folk with a shrug of the shoulder and the remark, "What do you expect? It is in the tropics." We forget that the civilization of the world was cradled in these hot lands, from which it spread to the barbarians of the north and south.

In these latter days, spurred on by the world-wide search for food to sustain our armies, we have turned again to this great belt of fertility and are beginning to undertake its development. This will be one of the important results of the World War.

The two great hindrances to tropical development have been lack of animal power for cultivating the soil and lack of animal transportation. The necessities of war have perfected the development of mechanical means of supplying these deficiencies - the automobile and the farm tractor. As a more rapid means of light transportation, the airplane has appeared upon the scene. The tropical jungle need not open to make a highway for it and the mountains need not bow to give it passage. Its road is always smooth and always straight.

The passenger automobile and the motor truck have gained a new prestige during the war. The theory that roads of high quality were necessary to the operation of motor transport has been effectively exploded by the achievements of power vehicles in operating in practically roadless territory with the armies.

The farm tractor has reached the point where we can say with confidence that it can be adapted to agricultural conditions anywhere in the world and perform with credit. Farm tractors are now being used in Peru which perform with one man and fifteen gallons of gasoline the day's work formerly done by fifteen men and fifteen yoke of oxen.

As important as the development of machinery has been the wonderful conquering of tropical diseases and development of sanitation, which has resulted in the elimination of yellow fever and other diseases which formerly made the 
hot climates dangerous. With the stories of Cuba and Panama and Rio de Janeiro and just recently Guayaquil, we can confidently eliminate health risks as one of the drawbacks of the tropics. It is most important that we have done with all of these preachments like that of Power's "America Among the Nations," which base their imperialistic assumptions on the eternal weakness of all that is related to the tropics.

\section{IMPORTANCE OF AMERICAN SOLIDARITY}

We need to have a clear understanding of the importance of American solidarity, both for our own safety and for the peace of the world. The Hon. Santiago Perez Triana of Colombia has well said:

"Law and order have found their refuge in America. We are the trustees of the liberty of the world and the guardians of the future. Let us do our duty. Not only the United States, as was once said by lips hallowed by martyrdom, were conceived in liberty and dedicated to freedom; that is the glorious heritage of all nations of America. Whatever tends to unite these nations in common bonds of friendship, of common interest or sympathy; whatever tends to strengthen their solidarity is a work not only for the peace of America but for the peace of the world."

The former Argentine Ambassador, Dr. Naon, has clearly stated the matter as follows:

"Pan Americanism can never exist with the idea of privileges in the discussion of general destinies on the part of the stronger or more populous nations and in detriment of the principle of equality on the part of the weaker nations. On the other hand, apart from Pan Americanism as the system of international organization for America, the political influence of the United States will have become crippled, while that of the other nations of America will have been reduced almost to the vanishing point. The union of this continent, which is, in my opinion, the essential concern of all the American nations, can be achieved only by the consolida- 
tion of Pan Americanism, which presupposes the inevitable prevalence of the principle of equality in deliberations that are of general interest, as imposed by right, by justice and by the exigencies of reciprocal co-operation in the maintenance of their international relations.

"Neither in the councils of the world nor in the consideration of the governments of the great powers do the nations of America enjoy either the moral respect that renders their sovereignty unassailable or the social consideration that imparts fecundity to the life of relation among peoples. These conditions have persisted now for a century and they constitute the fundamental problem of the continent, for us even more fundamental than all the problems that are to-day being discussed at the peace conference. The United States, as an integral part of the continent, and as the most conspicuous exponent of its capacities, is affected by these continental conditions as much as any other of the American nations can be.

"As long as the countries of the continent are kept in these conditions of inferiority in world politics, there will continue to exist for the United States the causes that gave rise to the Monroe Doctrine and consequently all its objections will also continue to exist. The United States is therefore interested in having these conditions disappear, for reasons that concern her own preservation and her own security; and until they shall have vanished, her political influence in the world, her weight in international councils, will be relatively much more apparent than real.

"Hence my unalterable conviction that there is no political interest more essential to the United States than the consolidation of the Pan American idea as an element sine qua non of her international policy."

The following testimony of the importance of Pan Americanism, coming from France, the guardian of Pan Latinism, is still more significant. A. Demangeon in his book, "America and the Race for World Dominion," just off the press, says ·

"Pan Americanism is a doctrine of material interests and 
of sentimental affiliations. It means that there is an American civilization henceforth independent of European civilization; an American society free from the prejudices, the castes, and the hatreds of European society; an American policy that should be liberated from the ambitions and the traditions of European policy; and an American economy rich and pliant enough to be no longer the slave of European economy. This dcctrine, adopted by the young nations of America, urges them to unite from one end of the continent to the other in order to coördinate their interests and cultivate mutual esteem. It works for the building of an American federation that will bring about practical, political and material unity. Pan Americanism is no longer merely a doctrine, a symbol. The foundations have already been laid for a systematic organization."

More than a decade ago President Roosevelt showed the right attitude, when, at the laying of the cornerstone of the Pan American Union Building, he said: "I greet the representatives of all our sister republics to the South of us. In a sense you are our elder sisters and we the younger people, for you represent a more ancient civilization on this continent than we do. Your fathers, the Spanish and Portuguese explorers, conquerors, law-givers and commonwealth builders, had founded a civilization in the tropics and South Temperate Zone while all north of Rio Grande was still an unmapped wilderness. $* * *$ For centuries our several civilizations grew each in its own way, but each sundered from the others. Now we are growing together. More and more in the future we shall each give to and get from the others, not merely things of material value, but things that are of worth for the intellect and spiritual welfare of all of us. In the century that has passed the development of North America has proceeded faster, on the whole, than that of South America, but in the century that has now opened I believe that no other part of the world will see such extraordinary development in wealth, population and all that makes for progress, as will be seen from the Northern boundary of Mexico throughout all Central and South America."

The importance of the United States' seizing the present 
propitious time for a vital unity of all America is pointed out by Dr. Rafael Urtecho as follows :

"Inasmuch as the ties of the United States with the American states are of a permanent and not a transitory or accidental interest, as are those that unite her with the nations of Europe, it may well be said that one of the advantages-the greatest of them, perhaps-which the United States has secured through the war that has just concluded, and in which she took so important a part, is to be found in the new attitude of the Latin-American peoples, in whom has been awakened a sentiment of admiration for and sympathy with the United States: a sentiment that was greatly needed to give life and strength to the Pan American doctrine.

"Reciprocal prejudices growing out of a lack of understanding between the two peoples-their languages, their customs, their character and their virtues-caused the nations of the New World to regard each other with suspicion and distrust; and so, in the hour of the great universal confict, the Hispanic nations adopted divergent courses and thus revealed to the world a want of efficacy in the Pan American doctrine, destined, however, to prevail and to be adopted as the natural orientation of these countries in their desire for progress and well-being.

"Fortunately, by the course of events, the veil that covered our eyes has now fallen, and we are enabled to see in the great collective soul of the North American nation a vivid flash of noble and generous ideals: that not always are her purposes materialistic and sordid; that it is not-as has been believed-an oligarchy of capital or, rather, a plutocracy, prouder, perhaps, than an aristocracy of blood, that dominates her counsels, but her loftiest intelligences and the rectitude and moral superiority of her great men, always at strife with the high-handed and absorptive tendencies of capital.

"It is now highly important that the prejudices which the United States may entertain regarding these countries should disappear, and to this end it is necessary that she know us better and become convinced that in the depth of 
the Hispanic mind and soul there exists the germ of all greatness and all superiority-this germ only needing proper cultivátion for its development; that, at all events, we are the descendants of that heroic race which at one time held the empire of the seas and of the land: a valiant, proud, haughty race, full of gravity and a very highly developed sense of honor; for, although in the melting-pot of the American race we mingled, unfortunately with inferior races, there always remained in the blood the germs of the primitive race.

"It is necessary that the United States know our language, our history, our literature, and, above all, that the North American people, in contact with ours, try to show more tolerance and more adaptability in respect of our customs and social environment."

\section{URGENCY OF A BETTER INTER-AMERICAN UNDERSTANDING}

We need to create on this continent what a great teacher has defined as "An atmosphere in which we loathe to differ and determine to understand." Let us frankly realize the distinctive differences between cold-blooded, truth-seeking, organizing, practical Anglo-Saxons, and warm-blooded, favor-dispensing, theoretical, idealistic Latins, appreciating the importance of all these characteristics.

North Americans often have little sympathy for Latin Americans because they have never taken into account the fundamental truth expressed in the following words of President Roca of Argentina :

"The genii that surrounded the cradle of Washington were not the same as presided at the advent of the South American democracies. The proud conquerors of iron mail who trod this part of America with rare notions of liberty and right, with absolute faith in the effect of brute force and violence, were very different from those Puritans who disembarked at Plymouth with no arms but the Gospel, no other ambition than that of founding a new community under the law of love and equality. Hence the Latin republics stand in need of a greater amount of perseverance, judgment 
and energy to work out their original $\sin$ and to assume those virtues which they did not inherit."

Rear Admiral Chadwick clearly points out the mistake of the people of the United States in this regard in the following words:

"It is this lack of understanding of what race character means that causes our trouble. It is a study of temperament, disposition, outlook on life, a study, in a word, of all that goes to make up character that we need for successful dealing with races so essentially different from our own. In such study is the crux of every international problem or of any other problem concerned with the conduct of men. We have certainly ignored this, at least as far as Latin America is concerned, almost in toto. It is time we were taking another course and knowing the soul of other peoples."

Some will think that this has nothing to do with the practical things of life. But that is just exactly their mistake. It is the most important part of foreign commerce. The tragedy of our failure to understand Latin America is just now being brought home to us in the frightful way we are losing the trade of those countries, which was delivered into our hands during the war. While it is too early to make categorical statements about final trade results, the plain truth is that we have made a terrible botch of the way we have handled this trade. There are excuses for some failures to fill orders and there are honorable exceptions to the general failure, but there is no getting around the fact that because we refused to adapt ourselves to our customers' desires and have insisted on our own way of doing business, the merchants of every country in South America are up in arms against North American business methods. One of the biggest business men in Peru has just declared to me, in spite of the fact that he is an ardent admirer of this country, that he is through with American firms.

His argument is about like this: "If I buy a machine from England or Germany they install it on my place, set it running and call me to see it. Then I am ready to pay the bill, 
with all the extras. But the North American sends me the machine, which I must set up. It does not do the work. Then I myself have to send to the United States for an expert to put it in running order. Or I order a tractor, and pay for it, as required, in advance. It comes all smashed to pieces. The company gives me the insurance receipt and tells me to collect the money. I do not want the money, I want the tractor; and I want a firm to stay by my order until it is filled and the machine is running properly. This costs the firm extra, of course, but I am willing to pay a few hundred or a few thousand dollars extra. Then, if I need a machine to do certain work. I want to be able to get that machine by telling the manufacturer or his agent what I need and leaving them to figure out precise size and type of apparatus required, sending a technical man to my place if necessary. The English or the German firm will take the whole matter in hand and see it through. But the North American wants to deal with me as though Peru had at its beck and call all the facilities of an Illinois center. And to save our lives we can't get him to look at our situation as we see it instead of as he thinks it ought to be."

I repeat that it is a real tragedy to see how the North American business man, in failing to read Latin American psychology, has created recently so much opposition in commercial circles.

There can be no true American solidarity until the various peoples really know each other-understand each other's point of view, habits of thought, literature and life. And if we do succeed in capturing Latin American trade, we must not be satisfied with that. There was a time when England practically controlled the trade of South America and yet exercised no appreciable intellectual influence there. On the other hand, France, with but little commercial relationship, has exerted a powerful dominion over the thought and action of the people of Latin America. Germany, in attaining her commercial supremacy, sought to build for the future, sent teachers to reorganize the lower and high schools of these countries and in many ways strove to place her best intellectual forces at their disposal.

We must work actively for intellectual and spiritual in- 
tercourse. We are ill prepared, however, to meet the demands of the present situation. With good will and an honest desire to co-operate, we hardly know how because of lack of acquaintance with one another. Our acquaintanceship must be systematically promoted and American ingenuity must find a way to transfer the very general desire for good relationships into actual practice.

We have held international congresses during the years with splendid results but they are necessarily superficial; they partake too much of the nature of parade to afford opportunity for that tranquil and extended interpenetration of spirit which is essential to intellectual comprehension and social intimacy. Knowledge of history, of the road by which peoples have reached their present state, of national heroes, ideals and aspirations, of literature, art, the progress of the sciences, and of education, is what is needed before there can be any co-operation between peoples.

Our southern neighbors know us better than we know them. The names of Washington, Clay, Lincoln, Poe, Whitman, Longfellow, Emerson, Mark Twain, Cooper, Irving, and Edison are as familiar to them as those of their own equally great Bolivar San Martin, Sucre, Hidalgo, Bello, Heredia, Ricardo Palma, Rubén Dario, and Oswaldo Cruz. In respect to international knowledge, our neighbors have outdistanced us; for they not only know Europe as well as we do, but they also know us much better than we know them.

Señor Nebuco, Brazilian Ambassador to the United States, has put the matter of American friendship very beautifully in the following words:

"Much as the future generations will wonder at the progress of our time they will wonder still more that the two great sections of our continent did remain so late in history almost unknown to each other. One reason of their isolation was that many spirits in Latin America were for a long time afraid of a too close contact with you, owing to the great difference of power between this and every other American nation. On its side the United States, being a world by itself, and a world growing faster each day, has 
always opposed to any such movements the strongest of all possible resistance, that of indifference. Fortunately a new cry begins already to resound everywhere. Suspicion is being replaced by confidence, and, if the universities take in hand the policy of Secretary Root, indifference, in its turn, will give way to the feeling of continental kinship.

" *** The only certain effect I can see of a permanent and intimate intercourse of Latin America with you is that it would be slowly Americanized; that it would be, in different measures, penetrated with your optimism, your self-reliance and your energy. It would be a treatment by electrictly. I do not mean that we would ever attain your speed. Nor do we wish it. You have broken the record of human activity without breaking the rhythm of life. You have made a new rhythm for yourselves. We could never do that. For the Latin races festina lente is the rule of health and stability. And let me say it is good for mankind that all its races do not go at the same step, that they do not all run. The reign of science has not yet begun, and only in the age of science might mankind attain to uniformity without beginning at once to decay. Dignity of life, culture, happiness, freedom, may be enjoyed by nations moving slowly, provided they move steadily forward."

Because the problem is so much of an intellectual one, Dr. Ernesto Quesada, of the University of Buenos Aires, suggests that it is a matter in which the universities should lead. He says :

"I have always believed that true Pan Americanism ought to be cemented by intellectual, rather than by political or commercial interests. This intellectual getting together, besides trips for study, is accomplished by the periodical assembling of congresses intended to bring into contact men of different countries, to make closer the relations among them and to make known among them their respective points of view.

"Unquestionably this is the most desirable result of such meetings, but it is a slow-working means to an end, one that requires many years to make its effects felt. Moreover, 
such conventions are usually made up of persons of advanced years whose opinions have long been formed, so that but few can be easily convinced. These conditions do not exist with respect to youth. When the universities shall undertake the propagation of a Pan American doctrine, the new generation will be readily convinced of its advantages, and will become its most effective herald.

"The University chair is, then, the most fitting platform upon which to maintain Pan Americanism. From this it will spread effectively to the secondary schools and later to the primary institutions. Soon even a child would become susceptible to its influences and in the space of one generation public opinion would become so favorably inclined to the doctrine that international politics itself in America would be forced to follow the current."

\section{VALUE OF EDUCATIONAL INTERCHANGES}

The effectiveness of the universities in such a program as is visioned by Dr. Quesada must have its foundation in a better understanding among the universities themselves. A beginning has been made along these lines by a tentative agreement between several prominent North American universities and the National University of La Plata, the National University of Chile and the University of San Marcos of Lima. The main points of this plan, held in abeyance during the war, may be outlined as follows:

I. To arrange for exchange of publications.

2. The establishment of a scientific bureau, which shall facilitate research, compile statistics and codify the results of scientific studies, bring together scientists engaged in research along the same lines, furnish information regarding methods of instruction and arrangement of courses, and, in general, make itself useful in putting at the disposal of the universities of both continents the scientic resources of them all.

3. The creation of a "Foreign Students' Information Bureau," which will furnish information concerning university life to interested students of any country and help 
such students upon their arrival at a foreign institution to adjust themselves to strange conditions.

4. The study of the development of political institutions in all the American republics in order to gain an insight into political development in any one of them, this material to be included in courses on comparative legislation, administrative law, sociology and political economy.

\section{THE EXCHANGE OF PROFESSORS AND STUDENTS}

A beginning has been made in the matter of exchange of professorships. One inaugurated between the University of Washington and the University of Chile has had most encouraging results. Another arrangement between the University of Chile and the University of California has been put into effect and the latter institution sent the wellknown historian, Dr. Charles E. Chapman, as its first exchange professor.

The question of the exchange of students is also making headway. In Brazil the National Congress recently passed a law providing not only for sending a large number of students to this country, but also providing six scholarships for North American young people and also voted to endow a chair of Brazilian history in George Washington University. The recent visit of Prof. Belaunde of the University of San Marcos to the United States has done great good. The Rector of the National University of Mexico, as a result of a visit of the President of the University of Arizona to Mexico recently made a trip to the western part of the United States upon the invitation of the Universities of Texas, Arizona and California, and arranged intellectual exchange between these institutions and the University of Mexico. The North American Chamber of Commerce in Mexico has recently promoted a vigorous movement to send Mexican students to the United States and within a few months has arranged for some fifty scholarships. Colleges of the United States will reciprocate by sending students to the University of Mexico. A movement which has been started to create scholarships for North American young men in Latin American countries is enlisting the 
cooperation of the business world through attempts which are being made to provide positions for North American young men in commercial houses of these countries and in commercial houses of the United States which have branches abroad.

Every effort is being made to encourage the attendance of Latin American young people in our universities and last year some 5,000 of them were scattered among the different institutions, double the number in the United States five years ago. The Pan American Union has an Education Department of which Dr. Francisco J. Yanes is Chairman which is doing all it can to assist such students. An extensive work of this nature is also carried on by the Committee on Friendly Relations Among Foreign Students, which publishes a magazine for the students. Among the various other organizations that are working along these lines may be mentioned the Institute of International Education, which has recently begun active promotion of exchanges between the universities of the North and South.

The number of such students could be increased by the thousands if the cost was not prohibitive. If large numbers of Latin American students are to come to the United States there must be a greater effort made to reduce the tuition and provide scholarships. Some notable attempts of this kind have already been made. Thirty-five universities and colleges in the United States now offer free tuition to Latin American students and several others have made even further concessions by means of scholarships, but the number must be increased.

The greatest barrier, of course, to the free development of intellectual relationships between the Americas is that of language. It would be difficult to overstate the importance of this. The increased interest in the teaching and study of Spanish in the United States and of English in the other countries augurs well for the future of American relations. A notable advance in the teaching of Spanish has been made recently in the formation of "The American Association of Teachers of Spanish," which, among other things, is publishing a remarkably fine magazine called Hispania.

Along with the study of language it is of prime impor- 
tance to awaken the interest of our young people in their American neighbors by including in the schemes of popular education proper courses of study upon the geography, history, institutions and varied character of the peoples with whom destiny has linked us for future cooperation. Many textbooks for the use of students of Spanish are coming from our publishing houses; numerous courses in Spanish and Portuguese literature have been introduced; several magazines devoted to inter-American affairs are being published, the most important of which are given in the reading references at the end of this chapter.

The Latin American people, on their part, are studying English as never before and books and periodicals concerning North American affairs are having a wide circulation. A number of the leading daily newspapers recently perfected arrangements with North American Press agencies which will keep their readers in constant touch with North American life. The head of the Modern Languages Department of the University of Chile reports that he had six pupils studying English when he took charge of the Department seven years ago, and he now has about three hundred.

\section{THE EXCHANGE OF GOOD LITERATURE}

It makes no difference what else we may do to introduce North American ideals to Latin America, we shall never accomplish all that we should until we have given them our literature. Latin Americans are particularly susceptible to the influence of books, as are all Latins. They place great authority on the written word. Heretofore they have known very little about our literature and, strange to say, works like those of Emerson, James and others of our philosophers that have become quite popular in certain circles in Latin America, are either read in French or have been translated from French or German editions into the Spanish. There are few things of more importance than a systematic effort to introduce American literature into these countries. If we can get them to read the lives of some of our great men like Washington and Lincoln and some books like Van Dyke's "American Ideals," Howe's "The American City," 
etc., great good would be accomplished. The Carnegie Endowment for International Peace and the Committee on Cooperation in Latin America are beginning to work on this program.

Our publishers and other business men who are interested in the permeation of Latin America with North American ideals, could do nothing more worth while than push this business. It would pay commercially, not only for the books themselves that were sold, but it would also create a generally good impression that would bring about a demand for all kinds of American goods. Now is the very best time to begin such a campaign. In the old colonial days Spain furnished the literature for the colonies. But when independence was secured from the mother country, her intellectual influence was largely lost. France came to be the ideal of these new countries. Her publishing ideals became the model for all of those countries and so it was that her books began to hold sway in the beginning of the last century. This lasted practically up to the present time. There has been, however, a gradual reaction against French literature by a great many of the best Latin Americans because of the indecent French novels and the obscene Parisian literature that have led many to outlaw all French literature.

During recent years Spain has taken note of this and has made a great effort to recuperate her lost trade in books.

But the bookmakers that have made the greatest strides in Latin America during the last twenty years are the Germans. They have studied very carefully the market, found out the kind of books that the people like and the kind of edition that appeals to them, and have given them this. They have translated a great many of the French and English and American authors into Spanish. As I said before, some of these translations of American authors have been made from the French rather than from the original English, showing how far we have been detached from Latin American literature and how difficult it has been for them to come in touch with us. The War of course cut off Germany from her book trade with Latin America and it will be a long time before she will be able to recover it. The present time, therefore, is most propitious, both from the commercial and the cultural 
standpoints, for us to circulate our American literature among our southern friends.

On the other hand, as has been shown in an earlier chapter, Latin America has produced and is producing a literature that is by every token worthy of our reading and consideration. The increasing study in the United States of Spanish and Portuguese should make a market for these books in their original languages. Meantime it is an encouraging sign that scholarly and appreciative translations of some of the best of them are beginning to appear on our book market. How can we ever expect to understand our neighbors until we can read and weigh the literature on which their intellectual life is nourished?

\section{SPIRITUAL AMBASSADORS}

One of the real reasons for the mutual misunderstandings between North and Latin America is that we have been afraid to discuss frankly the various phases of life bound up in our religious experiences and inheritances. Whenever such a thing is remotely hinted at in Pan American circles one is likely to be told that it is entirely improper to mention such divisive questions. But how can men be real friends and never talk of their belief in God? From Mexico to Chile I have recently presented the following idea to leading citizens: "We have had a fine period of Pan American getting together recently. Pan American conferences, exchange visits and other courtesies have greatly encouraged friendship. But you and I know that these have generally been quite on the surface. Has not the time come for us to discuss frankly the religious phases of our life? Protestant Christianity cannot be separated from the life of the United States. It has been and is the fundamental influence, the guiding motive in the life of most of our public men as well as those in private life. Roman Catholicism has certainly had a great influence in your country. To understand one another must we not stop fencing off the religious problem, and face frankly the question whether or not we can find those common truths in one another's religion that will bind us together and help solve our problems?" 
Almost every man to whom I have thus spoken expressed his agreement with this view. If we can in sympathy and love and frankness contribute something to this discussion it will be worth the mistakes and misunderstandings and criticism that erring human judgment is certain to bring.

We need a number of spiritual ambassadors going up and down this America of ours, cultivating understanding and friendship by interpreting to all the people the great truth that God has made of one blood all the nations and has called each and everyone to make its own particular contribution to the work of the world.

We have had such ambassadors in the past. Dr. Horace Lane went from the United States to Brazil to establish himself in business. But he fell so deeply in love with the Brazilians that he gave himself to helping them educate their youth. As the founder and president of Mackenzie College, he did more to endear North Americans to Brazilians than any governmental agent ever sent to that country. His funeral was the largest ever held in the city of São Paulo. As one travels through Brazil to-day he finds the name of Mackenzie College to be the key that everywhere unlocks the doors. The graduates of the school are found occupying the highest positions in official and commercial life.

What Dr. Lane was to São Paulo, H. C. Tucker, another North American, is to Rio de Janeiro. Going to Brazil thirtyfive years ago as the agent of the American Bible Society, he has so identified himself with the community that it may be said that he occupies a unique position of influence both with Brazilians and foreigners. He has so largely won the confidence of the municipality that it follows his ideas in putting in municipal playgrounds, in developing public clinics and hospitals, and in introducing modern means of sanitation and social betterment into the city's life. It was at his suggestion that the government decided to apply modern methods to the elimination of yellow fever from Rio de Janeiro.

John M. Silliman, a classmate of President Wilson at Princeton, was another of these ambassadors. For twenty or more years he lived as a "gentleman farmer" at Saltillo, Mexico. His up-to-date agricultural and dairying methods were used more to help his Mexican neighbors to improve 
their crops than to add to his own possessions. He was first in every movement for community betterment. He was equally popular among Mexicans and Americans. On Sundays, if there was no minister to speak to the little American congregation, he would hurry from his large men's bible class at the Mexican church to read one of Beecher's sermons to the Americans. And he found not only his American friends there but a good sprinkling of Mexicans wishing to try out their English and be near the big man they loved. It was no wonder that President Wilson in the difficult days of the Mexican Revolution found that Silliman was both his most reliable guide and the most acceptable American representative before the Constitutionalist movement. His death, brought about by pneumonia contracted in the work of bettering relationships between his native and his adopted lands, was mourned by friends all over Mexico.

How much it would mean if both the governmental world and the business world should keep in mind this idea of spiritual ambassadors as they select their representatives to these countries! This does not mean that they must be "preachers," or necessarily loud in their religious professions, but ministers, real evangelists of good will, whether business men, government agents or representatives of philanthropic or missionary organizations. They would take very seriously the work of interpreting the best of North American life to the Latin Americans, and would bring back to their own people a realization of the lovable traits as well as the serious needs of our fellow Americans.

In spite of all the misunderstandings of the past, great men both in the North and in the South have believed from the very beginning of the independent life of the American nations that, as Maia said to Jefferson, "Nature in making us inhabitants of the same continent has in some way united us in the bonds of a common patriotism." The persistence of the idea of American unity in the hearts and minds of great Americans through all these years is one of the outstanding phenomena of the history of the western hemisphere. Many have been the forces sent against it. Many have been the selfish influences both North and South that have intrigued for its destruction. But American unity 
must be of God: apparently it cannot be destroyed. After a hundred years of vicissitudes it is to-day more easy of realization than ever before. "God has made us neighbors, let justice make us friends," and let the needs of the world make us brothers for the service of humanity. Never was there so great an opportunity for this service as to-day, when many people are declaring that the war has so weakened Europe that the world's hope lies in America.

As we give ourselves to building this America, we find that, fortunately, the North and the South are complements the one to the other. This is true in the physical realm, where precisely the things that one is rich in are things the other lacks and vice versa. In the moral realm, while the North American is energetic, inventive, resourceful and practical, the South American is courteous, refined, openhearted and idealistic.

When, therefore, the ideal American appears, he will not be altogether the cold, organizing Anglo-Saxon, worshiper of truth, nor entirely the warm, philosophizing Latin, worshiper of grace, but he will be a combination of the twohe will be like the only perfect Man, of whom it was said that he was full of grace and truth.

\section{Sources of Further Information on Next Steps in Inter- American Friendship}

Bulletins issued by the Inter-American Section of the American Association for International Conciliation: among the most important are:

BlakesLee: Our Relations to South America and How to Improve Them.

GIL: Pan Americanism and the International Policy of Argentina.

GoldSMith: The Next Step in Inter-American Relations.

MOORE: Henry Clay and Pan Americanism.

Nabuco: The Approach of the Two Americas.

Oliveira-Lima: Relations of Brazil with the United States. Rowe: Possibilities of Intellectual Cooperation Between

North and South America.

Sherrill: The South American Point of View.

The University as a Factor in Pan Americanism.

Calderón, F. García: El Wilsonismo.

Inman, Samuel G.: Intervention in Mexico, Christian cooperation in Latin America. 
International Relations of the United States, an enlightening series of addresses by American Academy of Political and Social Sciences, I9I4.

Reyes, Rafael: The Two Americas.

SHERWOOD, G. A.: Glimpses of South America.

SPEer, Robert E.: The Unity of the Americas.

Files of South American, Inter-America, Pan American Bulletin, Pan American Magazine, Pan American Review, Hispanic American Historical Review, La Nueva Democracia. 


\section{BIBLIOGRAPHY}

Axers, C. E.: A History of South America, 1854-1904; New York, E. P. Dutton \& Co., 1912.

Alberdi, Juan Bautista: Estudios Económicos, Buenos Aires, "La Cultura Argentina."

Alvarez, Agustin: ¿Adonde Vamos?; Buenos Aires, "La Cultura Argentina."

. ARANDA, RiCARDo: Congresos y Conferencias Internacionales en que ha tomado parte el Peru ( 5 vols.); Lima, Peru; Publicación oficial del Ministerio de Relaciones Exteriores; 1909.

Atras America Latina: New York, General Drafting Company; 1919.

BARretr, John: The Pan American Union; Washington, D. C., Pan American Union; 1911.

Barret, Rafael: El Dolor Paraguayo; Montevideo, G. M. Bertani ; 1911.

. Bigelow, John: American Policy; New York, Chas. Scribner's Sons; 1914.

Bla Keslee, Geo. H.: Mexico and the Caribbean, Clark University Addresses; New York, G. E. Stechert \& Co.; 1920.

Bland, J. O. P.: Men, Manners and Morals in South America; New York, Chas. Scribner's Sons; 1920.

Blanco-Fombona, R.: Grandes Escritores de América; Madrid, Spain; Renacimiento.

Bompin, Manoel A.: A. América Latina; Rio de Janeiro, Brazil; H. Garnier.

Bonsal, Stephen: The American Mediterranean; New York; Moffatt, Yard \& Co.; 1912.

Bulnes, Francisco: Las Grandes Mentiras de Nuestra Historia, Mexico, Vd. de Ch. Bouret.

Calderón, F. García: Creación de un Continente; Paris; Librería P. Ollendorf.

Calderón, F. García: Latin America, Its Rise and Progress; London; T. F. Unwin; 1913.

Castañeda, Francisco: Nuevos Estudios; El Salvador; Imprenta Nacional San Salvador; 1920.

Chandler, Charles Lyon: Inter-American Acquaintances; Sewanee, Tenn., University Press; 1917.

Coester, Alfred: The Literary History of Spanish America; New York; The Macmillan Company; 1916. 
Cooper, Clayton S.: Understanding South America; New York; Geo. H. Doran Company; 1916.

Encyclopedia of Latin America: Marion Wilcox and G. E. Rines; New York; Encyclopedia Americana Corporation; 1917. EL IDEAL Latino-AMERICANo: Colección de documentos raros, protocoles, de diversos Congresos, memorias, de eminentes pensadores, etc., que se refieren a la projectada unión y confederación de los países centro-y sudamericanos; Mexico; Imprenta de la Secretaria de Gobernación; 1919.

Garcia, Meron Martin: Historia de la Diplomacia Americana, Buenos Aires; 1902.

Garrigo, Roque E.: América para los Americanos; New York; Garrick Press.

Gaviola, José: La Frontera de la Raza; Madrid, Spain; Tipográfico Artistico; 1917.

Godoy, F. Garcia: Literatura Americana de Nuestros Días; Madrid, Spain; Sociedad Española I Libreria.

Goldsmith, Peter H.: Brief Bibliography of Books in English, Spanish and Portuguese Relating to Republics Commonly Called Latin America; New York, The Macmillan Co.; 1915. Gonzales, Luis Felipe: Historia de la Influencia Extranjera en el Desenvolvimiento Educacional y Científica de Costa Rica; San José, Costa Rica; Imprenta Nacional; I92I.

Huerta, Cardus: Arado, Pluma y Espada; Barcelona, Spain; Imprenta Domeriech.

Inman, Samuel G.: Intervention in Mexico; New York; Geo. $\mathrm{H}$. Doran Co.; 1919.

International Relations of the United States: Annals of the American Academy of Political and Social Sciences; Philadelphia, Pa.; I9I4.

Jones, Chester Lloyd: Caribbean Interests of the United States; New York; D. Appleton \& Co.; 1916.

KIRKPATRICK, F. A.: South America and the War; Cambridge University Press; I9r8.

- LatanÉ, J. H.: Diplomatic Relations of the United States and Spanish America; New York; Doubleday Page \& Co.; 1920 (Revised edition).

Lobo, Helio: Cousas Diplomaticas; Rio de Janeiro, Brazil; Leite, Rebeiro y Maurillo; 1918.

- Lockey, Joseph B.: Pan Americanism, Its Beginnings; New York; The Macmillan Company; 1920.

Mackenna, B. Vicuna: Estudios Históricos; Santiago, Chile; "La Voz de Chile"; 1862.

Manero, Antonio: México y la Solidaridad Americana; Madrid, Spain; Editorial Americana; 1917.

Markham, Clement: Incas of Peru; New York; E. P. Dutton Co.; 1912.

MARTI, José: Los Estados Unidos; Madrid, Spain; Sociedad Español de Libreria. 
Maurtua, Anibal: La Idea Pan Americana y la Cuestión del Arbitraje; Lima, Peru; Imprenta La Industria.

MOORE, John BAssetT: Principles of American Diplomacy; New York; Harper Brothers; 1918.

Munro, Dana G.: Five Republics of Central America; New York; Oxford University Press; 1918.

New Pan-Americanism: Boston, Mass.; World Peace Foundation; 1916.

Oliveira-Lima, Manoel de: Evolution of Brazil Compared with Spanish and Anglo-Saxon America; Stanford University, Cal.; Stanford University; 19I4.

Ortiz, Fernando: La Reconquista de la América; Paris, Ollendorf.

Pan American Conferences and Their Significance: Philadelphia, $\mathrm{Pa}$; American Academy of .Political and Social Sciences; February, 1906.

Perez, Abet J.: América; Montevideo, Uruguay; "El Siglo Veinte."

Petre, F. L.: Simón Bolivar; New York, John Lane Co., 1918.

Pinochet, TANCREDo: The Gulf of Misunderstanding; New York; Boni \& Liveright; 1920.

Posada, Adolfo: En América, Una Campaña; Madrid, Spain; Francisco Beltrán; 1911.

Prado, Eduardo: A Illusão Americana; São Paulo; Brazil; Livaria Magalhaes.

Proceedings of the Second Pan American Scientific Congress: Washington, D. C.; Government Printing Office; 1917.

QUeSADA, ERNESTo: La Doctrina Monroe, su Evolución Histórica; Buenos Aires; Casa Editorial Coni; 1920.

Rernsch, PaUl S.: Public International Unions; Boston, World Peace Foundation; 1911 .

Reports of the Panama Congress on Christian Work; New York; Committee on Cooperation in Latin America; 1916.

Reyes, Rafael: The Two Americas; New York; Frederick Stokes Co.; 1914.

Robertson, Wm. SPEnce: Rise of Spanish American Republics; . New York; Appleton \& Co.; 1918.

Rodó, José Enrique: Ariel; Valencia, Spain; Editorial Prometeo. Root, Elinu: Latin America and the United States; New York; Harvard University Press; 1917.

Ross, E. A.: South of Panama; New York; Century Company; 1915.

Sarmiento, Domingo F.: Conflicto y Armonia de las Razas; Buenos Aires; "La Cultura Argentina."

ShePHERD, W. R.: Latin America; New York; Henry Holt \& Co., 1914 .

Sherrill, Chas. H.: Modernizing the Monroe Doctrine; Boston; Houghton, Mifflin Co.; 1916. 


\section{6

Speer, Robt. E.: South American Problems; New York; Student Volunteer Movement for Foreign Missions; I9I2. Sweet, WM. W.: A History of Latin America; New York; The Abingdon Press; 1919.

Ugarte, M.: El Porvenir de la América Latina; Valencia; F. Sempere y Compañia. 


\section{INDEX}

Adams, John Quincy, attitude toward Hispanic America, 107.

interpretation of Monroe Doctrine, 152.

Alberdi, Juan Bautista, analysis of Argentine life, 45.

favorable to Protestantism, 94. favorable to European intervention, 211 .

idea concerning Monroe Doctrine, 152.

ideas concerning immigration, 66.

quoted by Barcos, 53 .

student of democracy, 36 .

thesis on American unity, 121.

Alessandri, Arturo, address to Protestant ministers, 94.

Alsop Claim, cartoon on, 373.

Alvaiez, Agustin, criticism of the church, 50.

evil of the lie, 86 .

need of a liberal religion, 93.

Alvarez, Alejandro, proposals concerning the Monroe Doctrine, 208.

American Congress, meeting in Lima, 112.

results of, II3.

American League of Nations, suggested by Pres. Brum, 191.

Araucanians, wars with described by Ercilla, 20.

present condition of, 59.

Arbitration, boundary disputes settled by, 2 I I.

discussed at first Pan American Congress, 198.

early proposed in Latin America, 39.

first proposed at Panama Congress, I Io.

Argentina, advocate of arbitration, II7.
Argentina, attitude toward American unity, II5. education in, 80 . foreign population of, 67 . inclination toward Europe, II6. intellectual circle of, 28 . liberation of slaves in, 37 . problems of, 45.

Argüedas, Alcides, description of Indians' abuses, 57.

elements opposed to development of Latin America nanied, 65.

Assets of Latin America, intellectual values, 17.

rarket for manufactured,goods, 16.

power to produce raw materials, 16.

room for large population, 16.

Barbosa, Rua, address concerning world war, 253.

Barcos, José, advocates friendship with United States, 35I. need of more practical basis for Latin American life, 53.

Bayard, Thomas F., despatch concerning collection of claims, 213.

Bello, Andrés, ode to agriculture, 27.

Blaine, James G., calls first Pan American Congress, 196, 197. contribution to American friendship, 123.

ideas on Pan Americanism, 220.

Blanco-Fombona, Rufino, indictment of North America, 330. opposition of two Americas, 328.

studies of Latin American life, 47. 
Bolívar, Simón, attitude toward United States, 106, 324.

death of, III.

favorable to immigration, 66 .

Jamaica letter, I03.

work for American unity, 104, I05.

Bomfin, M., need of education in Brazil, 83.

on ills of Latin America, 55.

Brazil, early suggestion of American unity, IOI.

independence of, first recognized

by United States, 130, I3I.

Brum, Baltazar, advocates Latin

American federation, 36r.

idealism of United States, 347, 348.

suggests American league, 191.

Bryan-Chamorro Treaty, protests against, 305, 307.

Buchanan, W. J., proposed arbitration to Argentina and Chile, 21 r.

representative of United States in Central American Conference, 299.

Buenos Aires, beauties of, 40.

Bulnes, Francesco, clerical propaganda, 343 .

description of Latin America's problems, 46.

Bunge, C. O., future of South America, 56.

psychological studies of Latin America, 48.

Calderon, F. Garcia, attitude of Argentina toward American unity, 116.

comments on Monroe Doctrine, 168-171.

condemnation of politicians, 65 . description of two forms of Americanism, 328, 329.

book translated into English, 55.

religious renaissance needed, 93.

Calderón, Ignacio, appeal for Indians, ór.

Canning, George, connection with Monroe Doctrine, 151, 152.
Caribbean Countries, economic resources of, 274, 275.

growing influence of United States in, 270-271.

strategic importance of, 272.

suggestions for better relations with, 320, 321.

Castañeda, Francisco, studies concerning American unity, IOI.

Caste, prevalence in Latin America, 65 .

Central America, attitude toward United States, 318.

conference called by United States and Mexico, 298, 299. court of justice organized, 299, 300,301 .

movements toward unity, 297. welcome of moral assistance, 319.

Chadwick, F. E., advises against intervention in Mexico, 376.

states need of study of temperament, 389.

Child Welfare Congress, address at, 256.

Chile, changed attitude toward United States, 247.

liberation of slaves in, 37.

North American student in, 23. parliamentary system in, 38 .

Chinese, presence in various American countries, 68.

Chocano, José Santos, singer of American friendship, 355.

"Christ of the Andes," statue commemorating aribtration victory, 211.

Civilization of Latin America, described by Theodore Roosevelt, 386 .

preceded by Indian civilization, 17.

recognized by Elihu Root, 17 .

Clay, Henry, fight for recognition of Spanish American states, 135, 136, 137 .

writes instructions of United States delegates to Panama Congress, 107.

Clemenceau, Georges, opinion of South America, 42.

Cleveland, Grover, protection of Venezuela, I75. 
Collection of Claims, case of Venezuela, 214, 215.

President Roosevelt on, 213.

Secretary Bayard on, 2r 3.

Colombia, action in regard to Panama Canal, 279, 280.

plans for American congress, I 6.

religious problem in, 92.

settlement with by United States, 282.

Colmo, Alfredo, comparison of United States and Latin America, 5I.

Commercial Relations, aid to American friendship, 356.

dependent on good understanding, 389 .

increase of between the United States and Hispanic America, 229.

rapid development of, 15 .

struggle of various nations to increase with Hispanic America, 239-242.

Committee on Coöperation in Latin America, work for American friendship, 244.

Continental Treaty for protection against United States, 115.

Cruz, Oswaldo, directed sanitation in Rio de Janeiro, 33.

Cuba, commerce of, 16 . economic development of because of world war, 232. educational problem, 80. early desired by United States, 272.

Dario, Rubén, changed attitude toward United States, 366. ode to Roosevelt, 363 .

Democracy, insistent ideal in Latin America, 35.

Diplomacy, need for improvement in North America, 377.

Drago Doctrine, statement of, 215.

Economic Problem, involves foreign complications, 72.

Economic Resources, increased by world war, 230-233.
Education, problem among Indians, 6r.

problem in Haiti, 295.

problem of, 78,79 .

progress of in Santo Domingo, 287.

questions of curriculum, 85 .

El Salvador, political attitude of, 3 II.

Fine Arts, Latin America's appreciation of, 20.

Foreign Concessions, baneful influence of, 73, 75, 265 .

exploited in Honduras, 74. overstated in Venezuela, 74

France, commercial relations of with Hispanic America, 240.

French Influence in Latin America, democratic idealism, 35 .

Friendly Visitors, sent to Hispanic America by various countries, 243.

Garcia, Juan A., analysis of Hispanic American life, 48. Garrigó, Roque, author of "America for Americans," 355.

Germany, colonists in South America, 67.

commercial activities of, 16 .

present economic relations with Latin America, 24I.

propaganda in Central America, $341,342$.

Godoy, F. Garcia, argument for

Pan Latinism, 326, 327.

objections to immigration, 65 .

visit to his home, 288.

Grant, Ulysses S., condemnation of Mexican War, 143.

declaration against intervention, 212.

proposal to annex Santo Domingo, 273.

Great Britain, attitude toward independence of Brazil, I3I.

economic relations with Latin America, 24I.

help given Spanish colonies, I26.

Guatemala, reference to "manifest destiny" by, II5.

revolution against Cabrera, 3 I 3 . 
Hague Conference, action concerning Drago Doctrine, 215.

Latin America's place in, 218.

Haiti, backwardness of, 290.

educational needs of, 295.

moral obligation of United

States toward, 296.

North American occupation of, 290, 291, 292.

Hamilton, Alexander, help for Miranda, 127.

Harding, Warren G., comment on Monroe Doctrine, 164, 189. election commented by La Nación, 188.

Hay-Herran Convention, 279.

Hay, John, negotiations concerning Panama Canal, 278, 279, 280.

Hay-Pauncefote Treaty, 279.

Heredia, José M., ode to Niagara, 43.

Hidalgo, Miguel, decree against slavery, 37.

Hostos, Eugenio María de, versatile life of, 28.

Huerta, G. Gardus, quoted concerning the church, 9 I.

Illiteracy, prevalence in Latin America, 79, 80.

Immigration, advocated by Barcos, 55 .

advocated by Sarmiento, 45 .

needed in Latin America, 65, 66. problem of German and Japanese, 67 .

Imperialism, confused with Monroe Doctrine, I72.

feared in Latin America, 266.

evil effects in Haiti, 29I-293.

Indians, art of, 22.

Calderon's appeal for, 6I. early civilization of, 17 .

ill treatment of Yaqui, 64 . problem of stated, 57-64.

Ingenieros, José, quoted concerning social problems, 262.

Intellectual Circles of Latin America, early attainments of, 2 I.

present members of, 22, 23.

International Policies of America, three important ones, 98.
Intervention, evil effects on American friendship, 375.

Lord Palmerston on, 213 .

Mexican protested by Ugarte, 335.

North American in Haiti, 290.

North American in Santo Domingo, 282, 283, 289 .

not justified for collection of claims, 213.

opposed by president of Colombia, 339.

opposed generally by Latin America, $21 \mathrm{I}$.

United States in Cuba, 275277.

United States in Nicaragua, 303. urged in Mexico by financial interests, 265.

various instances of in Latin America, 2II.

various types of, 211 .

Japan, alliance with, not feasible, $358,359$.

alliance with Latin America advocated by Ugarte, 336 .

commercial activities of, I6.

economic relations of with Hispanic America, 242.

sends immigrants to Latin America, 67, 68.

Jefferson, Thomas, interview with Brazilian students, 126.

letter to Claiborne on friendship for Spanish America, I27.

on Monroe Doctrine, 149.

Juarez, Benito, favors Protestantism, 94 .

Kindness of Latin Americans, shown in various ways, $4 \mathrm{I}$.

Labor Movement, development of, 238, 239.

La Nacion, reference to Monroe Doctrine and League of $\mathrm{Na}$ tions, 188.

Land System, evil results of, 63.

Language Study, need of, 395.

La Prensa, approval of Pres. Wilson's message, 356 .

home of, 20. 
La Prensa, comment on early friendship between Argentina and United States, 129.

resents North American diplomacy, 372.

Lane, Dr. Horace, founds Mackenzie College, 399.

League of Nations, attitude of Latin America toward, 176.

preference for in Latin America, 369.

Lincoln, Abraham, condemnation of Mexican War, $143,144$.

Sarmiento's life of, 324 .

Literature, early examples of Latin American, 34.

exchange of necessary, 396 .

need of knowing Hispanic American, 39I.

Literature of Latin America, emphasis on democracy, 35 .

Lobo, Helio, shows unfairness of North American critics, 353.

Love of the Artistic, various ways shown by Latin Americans, 40.

Lugones, Leopoldo, address concerning World War, 252.

Madison, James, friendship for Latin America, 131, 132.

Manifest Destiny, boasted by United States orators, 146.

criticized at Second American Congress, II9.

lessened by Civil War, 195.

objected to by Guatemala, II5.

Mediation, between United States and Mexico, 217.

outstanding cases in America, 216.

Mexican War, caused changed attitude of Latin America to United States, 145.

condemned by Grant, 143.

Mexico, defended by Manuel Ugarte, 334, 335.

early friendly expressions to

United States, I4I, I42.

foreign holdings, $75,76,77$.

kindness of country people, $4 \mathrm{I}$.

land problem of, 63 .

liberation of slaves in, 37 .
Mexico, Mexican-American Commission, 23.

poet of, 24.

need of North American friendship with, 376 .

resents arrogance of Senate investigation, 373 .

Monroe, James, recognition of Hispanic American independence, 140.

issues his famous doctrine, 153.

writes instructions for first agents of United States to South America, 128.

Monroe Doctrine, confused with other policies, I7 I, 172.

debate between Prof. Bingham and Sr. Calderón, 166-170.

definition requested by $\mathrm{El}$ Salvador, 179-I8I.

definition of given by State Department, I 86.

discussion of at Fourth Pan American Congress, 207.

early approval by Central America, 100.

false interpretation pointed out by Pres. Lowell, 266.

favorable reception in Latin America, 154-156.

Great Britain's part in its proclamation, $15 \mathrm{I}$.

interpreted imperialistically by certain leaders in United States, 147, 165.

meaning as defined by various authorities, 157, 158, 159, 160.

need of clear definition of, 193, 374.

popular misunderstanding of, I49.

relation to collection of debts, $16 \mathrm{r}$.

relation to League of Nations, 176-182.

text of, 153, 154 .

Montalvo, Juan, exaltation of Christianity as author of democracy, 36 .

Moore, John Bassett, on Pan Americanism, 22I.

Moral Problem, analysis of, 86. 
Nabuco, Juaquin, address at Washington, 222.

home of, 32. immigration a common American problem, 68.

mutual indebtedness of the Americas, 39r.

proposal concerning Monroe Doctrine, 207.

reference to Princess Isabela of Brazil, 35.

Naon, R. S., on importance of

Pan Americanism, 384 .

Nervo, Amado, poem on "Mystics," 25.

work of, 24.

Neutrality, benevolent by United

States toward Spanish colonies, I26.

Niagara Falls, Heredia's ode to, 43 .

Nicaragua, intervention in by

United States, 303.

Oliveira Lima, Manoel de, visit to, 32.

Olmeda, José Juaquin de, ode to Bolivar, 26.

Olney, Richard, interest of United States in all America, 175.

Pan Americanism, commercial aspects of, 228, 229.

confused with Monroe Doctrine, I73.

early expressions of, 99 .

early suggested by Brazilian student, I27.

events increasing importance of, 218.

definition of, 220-22I.

importance of pointed out by Naon, 384.

importance recognized by French author, 385 .

increased by World War, 245. non-American and inter-

American aspects of, 210.

opposed by Pan Latinists, 323 .

opposers of quoted, 328-332.

prejudice against term, 360 .

school of, 347.

significance according to various Hispanic Americans, 223, 224.
Pan Americanism, various Latin American advocates quoted, 347-354.

Pan American Congresses, first held in Washington, 196. second in Mexico, 199. third in Rio de Janeiro, 201. fourth in Buenos Aires, 205. arbitration discussed, 200 . attitude of Latin America toward, 197. results of, 198.

Pan American Federation of Labor, organization and principles of, 234, 235.

Pan American Financial Conference, sessions in Washington, 227.

Pan American Union, dedication of building, 218 .

department of education, 395.

organization of, 198.

reorganization at third Congress, 204.

Panama, early treaties concerning, 278, 279.

resentment against seizure of Taboga, 37o.

Panama Canal, history of traced, 278.

Panama Congress, called by Bolívar, I824, I04.

Bolivar's admission of failure of, III.

delegates present, ro4.

instructions of delegates of United States, 107.

purpose of, 105 .

proceedings and conclusions of, IIO.

Pan Latinism, not inherently opposed to Pan Americanism, $36 \mathrm{I}$.

opposed to Pan Americanism, 325.

representatives of, 325 .

reviews published to advocate, 338.

strengthened by Spanish American War, 325.

Paraguay, educational problem of, 82.

intellectual circle of, 26.

Perez, Abel J., need of religion, 95. 
Peru, education in, $79,82,84$. Pinochet, Tencredo, shows American misunderstandings, 360.

Platt Amendment, text of, 277.

Poinsett, Joel R., appointed agent to South America, 128.

reception of, 129, 130 .

Political Idealism, persistence in Latin America, 34.

Population of Latin America, density of, 16.

Prada, Gonzales, attacks faults of Peru, 49.

Prado, Eduardo, indictment of United States, 336.

Prado, Javier, admiration for United States, 354.

Printing presses, early inaugurated in Hispanic America, 20.

Propaganda, against the United States, 34 1-345.

commercial against United States in Latin America, 344346.

used by Clericals, 344.

Psychology of Hispanic Americans, differs from North Americans, 98.

need of understanding same, 387.

value attributed to form, 387 , 388.

Quesada, Ernesto, Pan Americanism needs intellectual basis, 392.

quoted concerning world war, 246.

quotes United States political leaders on Monroe Doctrine, 147.

visit to his library, 28.

Racial Relations, harmonious in Latin America, 39.

Recognition of Spanish American States. Henry Clay's struggle for, 135-I37.

formal action in $1822,139$.

principles laid down by Adams, 134.

requested by Venezuela and Provinces of La Plata, 133, I34.
Religious problem, loss of Church's prestige, 259.

progress of evangelical movement, 93, 94, 95.

recognized by visitors to Latin America, 90.

students' attitude toward, 89, 92.

Restrepo, Carlos E., opposes intervention, 339 .

Rio de Janeiro, beauties of, 4I. elimination of yellow fever in, 33.

Roca, Julio, compares North and South America, 388.

Rodo, José E., advice to young men, 47.

opposition to North American materialism, 327.

Root, Elihu, activities in Central American conference, 298.

address at Rio de Janeiro, 202. falsely quoted, 340 .

letter concerning Nicaragua, 308-310.

recognition of Latin American civilization, 17.

said to be imperialistic, 338,339 .

Ross, E. A., statement of social problem, 69.

Roosevelt, Theodore, attitude toward Panama Canal, 28I. instruction to Mexican Conference delegates, 221 .

letter to Shaw concerning Panama, 28I.

on intervention for collection of debts, 213, 215.

recognition of older Hispanic American civilization, 386 .

remark concerning Panama, 270.

visit to South America, 210.

Salvador, attitude toward United States, 3 I2.

Sanitation, accomplishments in Rio de Janeiro, 33.

need of in various countries, 72 .

San Martin, José de, farewell address, 382.

favorable to American unity, IOI.

Santo Domingo, educational program for, 286, 287. 
Santo Domingo, evil results of military occupation, 289.

financial reorganization of by United States, 282, 283.

military occupation by United States, 287.

occupation of calls for help from Latin America, 332.

proclamation concerning American occupation, text, 283, 284. withdrawal of United States marines, 290.

Sarmiento, Domingo F., basis for regeneration of Argentina, 45 .

commends United States, 324 . works on government, 36 .

Scientists of Latin America, representatives named, 33 .

Second American Congress, sessions at Lima, I 18.

Semprum, Jesús, favors Pan Americanism, 348.

Shepherd, W. R., promoter of American friendship, 357.

Shipping Interests, development in Latin America, 242.

Shirt-sleeve diplomacy, danger of, 369,370 .

Silliman, John M., influence in Mexico, 400.

Slavery, early abolition in Latin America, 35, 37.

Social Problem, gravity of in Latin America, 69, 70, 7I.

Socialism, influence in Latin America, 259.

Sociologists, leading ones in Latin America, 45.

scarcity of in Latin America, 56.

Spain, efforts to cultivate kinship with Hispanic America, 346.

Spiritual Ambassadors, contributions to American Unity, 398.

Strikes, spreading in Latin America, 239.

Students, attacks on the Church, $89,92$.

brilliancy of, 30 .

demand for modern curriculum, 367.

influence of, 3 I.
Taft, Wm. H., falsely quoted, 340. policy toward Nicaragua, 304.

Temperance Movement, growth of in Latin America, $7 \mathrm{I}$.

Tamayo, Franz, strength of Bolivian Indians, 6r.

strictures on Latin American character, 49.

Tropics, new use of, 382 .

Turner, Clorinda Matto de, description of Indians' abuses, 59.

Ugarte, Manuel, analyses of Latin American life, $5 \mathrm{I}$.

influence of Mexican War on Latin America, I46.

latest attack on United States, 333,334 .

political weaknesses of Latin America, 65.

United States Marines, problems confronted in Haiti, 29I-294.

Unity of Central America, early movements toward, IIg.

Unity of America, address of Elihu Root, 202.

advocated by Vicuña Mackenna, 224.

attacked by Pan Latinists, 329, 330.

attitude of Argentina, I16.

championed by Peru, II5, II8.

contribution to by spiritual ambassadors, 398 .

debate concerning United States attitude toward, I25.

"dream" of del Valle, 100.

fatal influence of Mexican War, I 42.

favored by Bolivar, 103, 104, I05.

favored by early American statesmen, 125, 126, 127.

harm done by United States Senate investigation of Mexico, 373.

hindered by false propaganda, $344,345,346$.

hindered by United States attitude toward League of $\mathrm{Na}$ tions, I79.

ideal American, 401.

importance shown by Naon, 384 . 
Unity of America, influence of North American missionaries for, 357.

leadership in assumed by United States, 195.

Mexico's efforts for, I12.

necessity of shown, 358, 359, 360 .

North American sympathy with Brazil, I30.

not opposed by Hispanic American entente, 353 .

opportunities of the present, 368 . persistence of idea, 400 .

plan of Monteagudo, IOr.

present activities of United

States in developing, 243, 244.

present promoters of mentioned, 357.

process described by Nabuco, 391.

promoted by better acquaintance, 380 .

promoted by definition of Monroe Doctrine, 374.

promoted by exchange of literature, 395, 396.

promoted by threats from Spain, I19, 120.

promoted by visit of North American fleet, 360 .

promoted by World War, 245.

proposals of Panama Congress toward, 110.

shift of emphasis, 120.

studies of Francisco Castañeda, IOI, 122.

sung by Chocano, 355 .

Universities, Chile sends delegates to United States, 366.

contributions toward Pan Americanism, 392, 393.

dates of founding in Hispanic America, 18.

exchange of professors and students, 394.

rector of La Plata quoted, 88. students of Latin America in North America, 393, 395.
Urtecho, Rafael, consistency of American friendship, 353 . duty of United States toward Latin America, 387.

Uruguay, friendly attitude toward United States, 248, 249.

new experiments in democracy, 37.

Vargas Vila, J. M., charges of Yankee imperialism, 331.

Venezuela, foreign claims in, 74 .

Villaran, education in Peru, 84 .

Walker, William, invasion of Central America, I14.

Webster, Daniel, depreciation of Central America, 38I.

Wilson, Woodrow, definition of Monroe Doctrine, 173, 186, 190.

World War, attitude of Latin American governments toward, 244.

brought humility to Hispanic America, 254.

economic influence, 227.

effects on Latin America reviewed, 268.

evil results of reaction following, 368 .

influence of on spiritual life of Latin America, 251-255.

liberal movements resulting from, 257.

resultant dangers for Hispanic America, 264.

resultant materialism, $260,267$.

Zayas, Enriquez, R de, necessity of American unity, 358.

Zorilla de San Martin, Juan, address to North American sailors, 249.

Zumeta, César, analysis of Latin American problems, 46. 


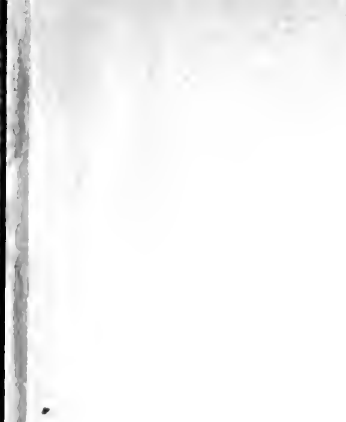



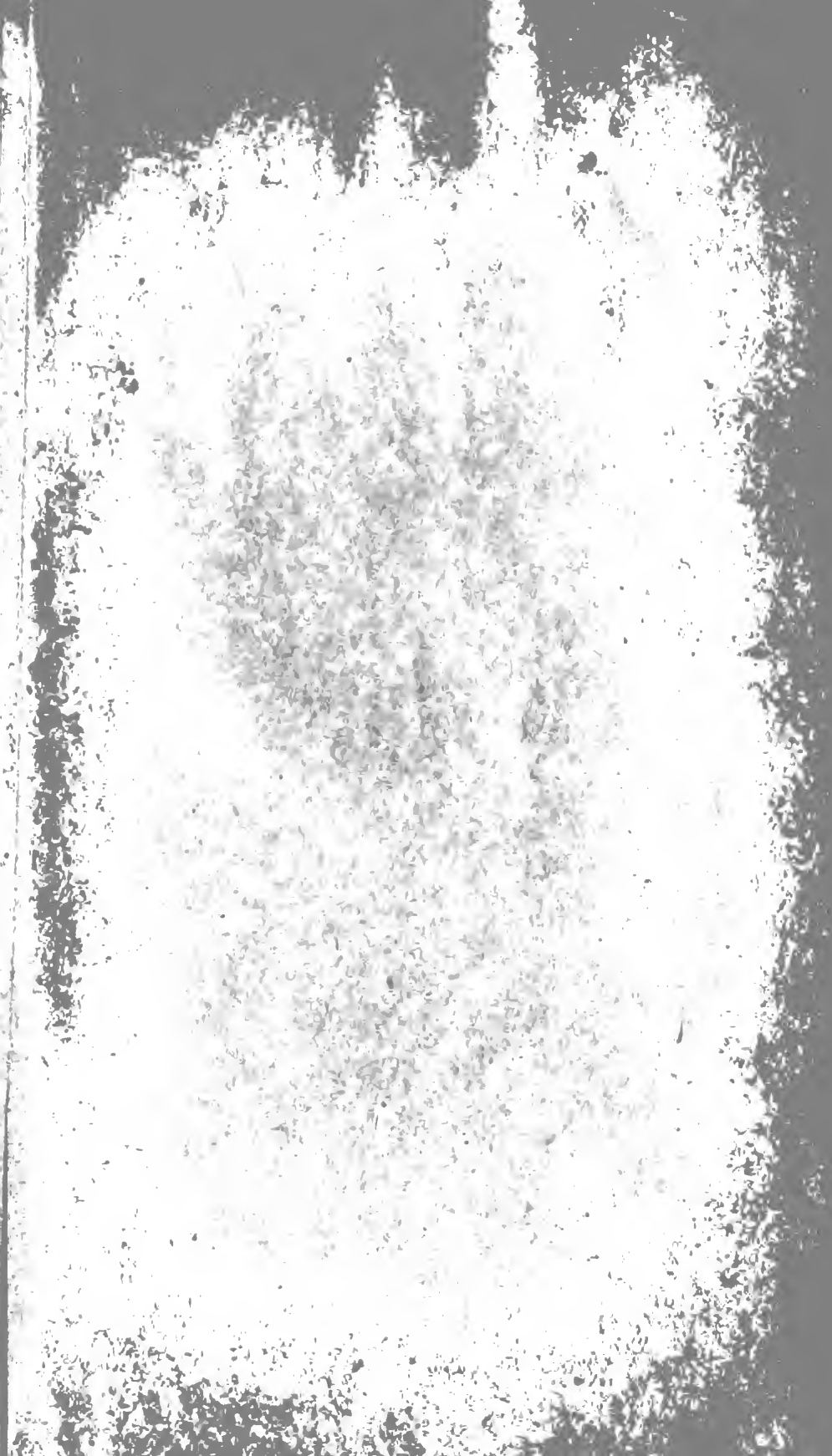




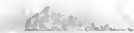

and

\section{DAY USE}

$\mathbf{T}$

RETURN TO DESK FROM WHICH BORROWED

\section{LOAN DEPT.}

This book is due on the last date stamped below, or on the date to which renewed.

Renewed books are subject to immediate recall.

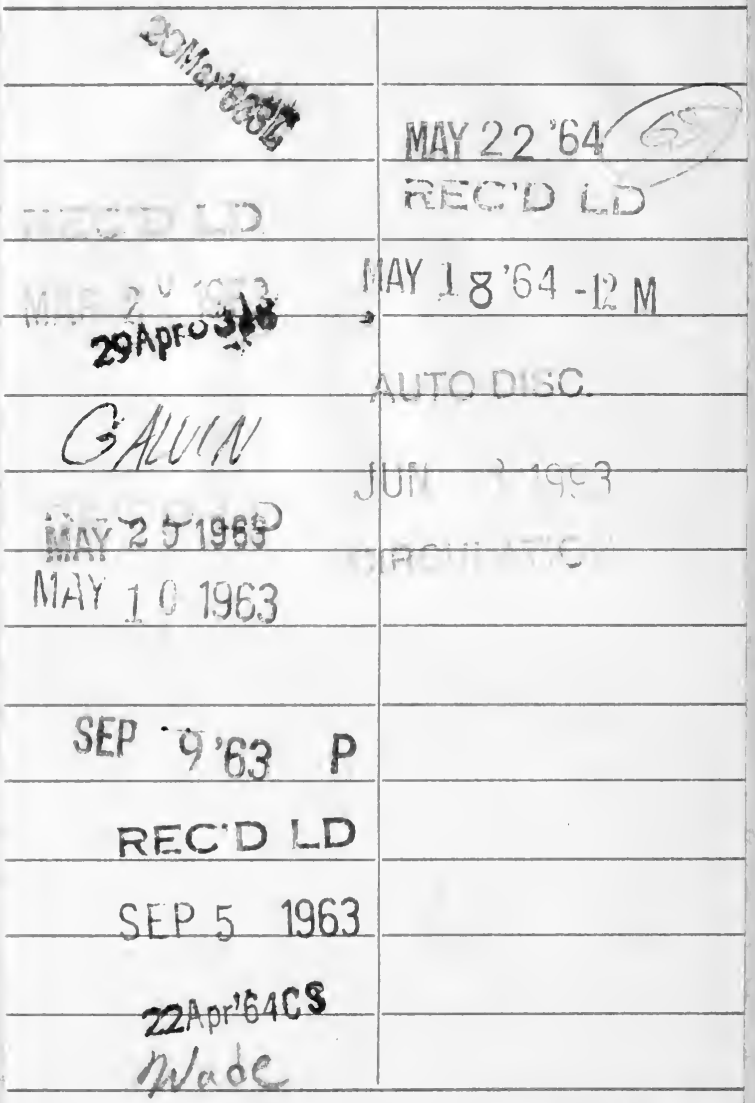




\section{Loods \\ YB 09030}

U.C. BERKELEY LIBRARIES

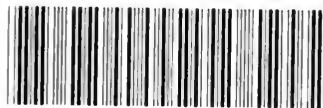

C035208348

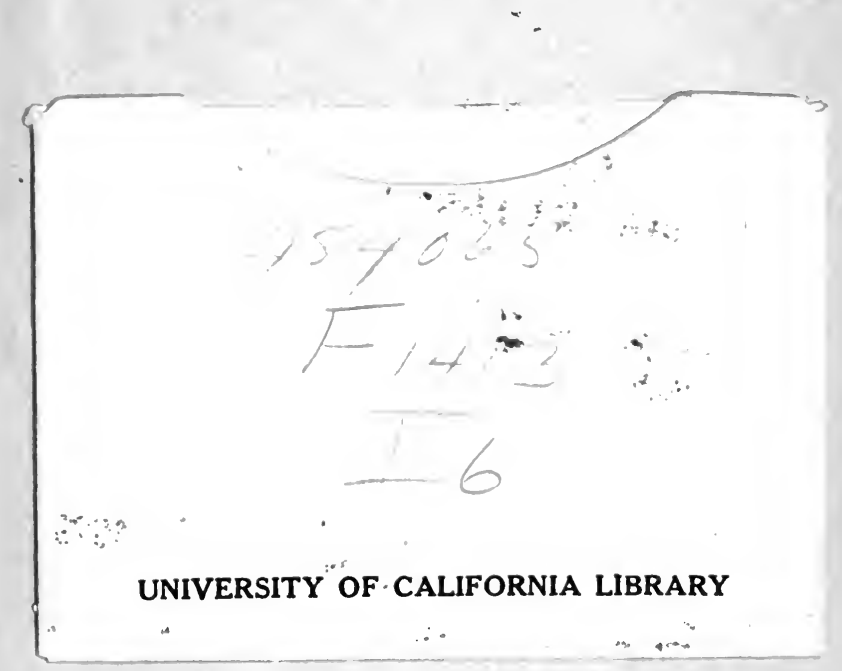

\section{UNIVERSITY OF CALIFORNIA LIBRARY}



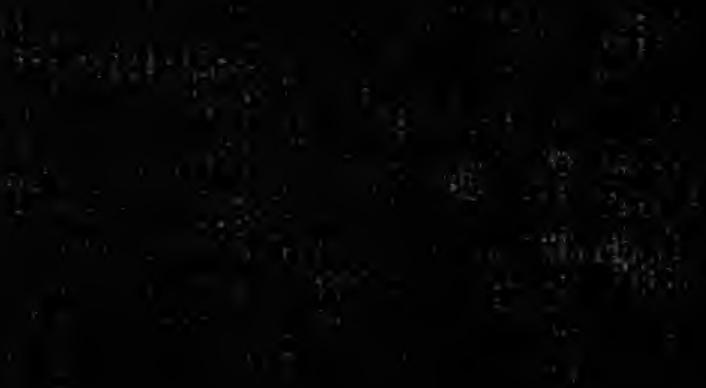

198

i:

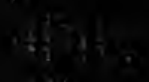

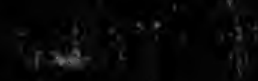

fotion 43

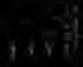

$-4-1$

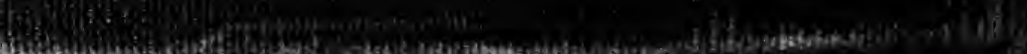

